Romke van der Veen I Mara Yerkes I Peter Achterberg (eds.)

$$
\begin{aligned}
& \text { The Transformation } \\
& \text { of Solidarity }
\end{aligned}
$$

Changing Risks and the Future of the Welfare State 
THE TRANSFORMATION OF SOLIDARITY 


\section{CHANGING WELFARE STATES}

Advanced welfare states seem remarkably stable at first glance. Although most member states of the European Union (EU) have undertaken comprehensive welfare reform, especially since the 199os, much comparative welfare state analysis portrays a 'frozen welfare landscape'. Social spending is stable. However, if we interpret the welfare state as more than aggregate social spending and look at long-term trends, we can see profound transformations across several policy areas, ranging from labour market policy and regulation, industrial relations, social protection, social services like child care and education, pensions, and long-term care. This series is about trajectories of change. Have there been path-breaking welfare innovations or simply attempts at political reconsolidation? What new policies have been added, and with what consequences for competitiveness, employment, income equality and poverty, gender relations, human capital formation, and fiscal sustainability? What is the role of the EU in shaping national welfare state reform? Are advanced welfare states moving in a similar or even convergent direction, or are they embarking on ever more divergent trajectories of change? These issues raise fundamental questions about the politics of reform. If policymakers $d o$ engage in major reforms (despite the numerous institutional, political and policy obstacles), what factors enable them to do so? While the overriding objective of the series is to trace trajectories of contemporary welfare state reform, the editors also invite the submission of manuscripts which focus on theorising institutional change in the social policy arena.

\section{EDITORS OF THE SERIES}

Gøsta Esping-Andersen, University of Pompeu Fabra, Barcelona, Spain Anton Hemerijck, VU University Amsterdam, the Netherlands Kees van Kersbergen, VU University Amsterdam, the Netherlands Kimberly Morgan, George Washington University, Washington, USA Romke van der Veen, Erasmus University, Rotterdam, the Netherlands Jelle Visser, University of Amsterdam, the Netherlands 


\title{
The Transformation of Solidarity
}

Changing Risks and the Future of the Welfare State

\author{
Edited by \\ Romke van der Veen, \\ Mara Yerkes and \\ Peter Achterberg
}


Cover illustration: Joseph Mallord William Turner, Snow Storm - SteamBoat off a Harbour's Mouth (1842)

Cover design: Crasborn Grafisch Ontwerpers BNo, Valkenburg a/d Geul Lay-out: $\mathrm{V}_{3}$-Services, Baarn

ISBN 9789089643834

e-ISBN 9789048515318 (pdf)

e-ISBN 978904851553 o (ePub)

NUR 740

(c) Romke van der Veen, Mara Yerkes and Peter Achterberg / Amsterdam University Press, Amsterdam 2012

All rights reserved. Without limiting the rights under copyright reserved above, no part of this book may be reproduced, stored in or introduced into a retrieval system, or transmitted, in any form or by any means (electronic, mechanical, photocopying, recording or otherwise) without the written permission of both the copyright owner and the author of the book. 


\section{Table of Contents}

Introduction 7

Risk and the Welfare State 13

Risk, Risk Perception and Solidarity

Romke van der Veen

2

Contested Solidarity 31

Risk Perception and the Changing Nature of Welfare State Solidarity

Romke van der Veen, Peter Achterberg and Judith Raven

3

Individualisation: A Double-edged Sword 49

Does Individualisation Undermine Welfare State Support?

Peter Achterberg and Judith Raven

4

Labour Flexibility and Support for Social Security 69

Fabian Dekker

5

Increasing Employability 91

The Conditions for Success of an Investment Strategy

Hans Pruijt and Pascal Dérogée

6

Corporatism and the Mediation of Social Risks 115

The Interaction between Social Security and Collective Labour Agreements Mara Yerkes and Kea Tijdens

Changing Labour Policies of Transnational Corporations 139

The Decrease and Polarisation of Corporate Social Responsibility Johan Heilbron and Sander Quak 
The Implementation of Workfare Policies

Peter Mascini, Menno Soentken and Romke van der Veen

9

Towards a New Welfare Settlement? 191

The Transformation of Welfare State Solidarity

Romke van der Veen and Mara Yerkes

Index of Names 207

Index of Subjects 213 


\section{Introduction}

The extensive literature on risk, risk society and the welfare state suggests that fundamental transformations are taking place that affect the social solidarity (Taylor-Gooby 2004, 2011) and the class compromise (Baldwin 1990) on which the welfare state rests. Post-industrial society produces new social risks (Bonoli 2004) that are not covered or can even be aggrevated (Cantillon, Elchardus, Pestiau and Parijs 2003) by the traditional risk protection programmes of the welfare state. Modern risk society (Beck 1992) is characterised by a new logic of social production of risks in which the welfare state itself has become a producer of risks, because it perversely affects the structure of employment, family life and marriage. Diversity, flexibility and uncertainty are increasing in social relations but also at the level of ideas. Consequently, the life course is seen to be the result of the choices made by individuals throughout their lives and therefore the structure within the individual life weakens (Beck and Beck-Gernsheim 2002). All these transformations are suggested to erode welfare state solidarity. Notions of individual choice, individual failure and individual responsibility become more important in people's views about risks and the welfare state and therefore traditional welfare state solidarities are dissolving.

It is this line of reasoning that is investigated in this book. By analysing the changing perceptions of risks and the changes in the willingness to show solidarity with others, we investigate whether traditional welfare state solidarities are dissolving and whether a new basis for solidarities is coming into being.

The welfare state was founded on a shared perception of the social nature of risks people encounter in everyday life and the willingness to take some form of collective responsibility for these risks. This responsibility is subsequently translated into collective strategies of risk management: the social policies of the welfare state.

In the main institutions of industrial society, the firm and the city, the risks of poverty, sickness or unemployment became systemic risks, that is: 
the unintended result of production processes, economic cycles, life cycles and of processes of urbanisation. The welfare state is in the first place founded on the perception of these risks as social risks, that is: the risks arising from the main institutions of industrial society gradually came to be seen as produced by 'the system' and not by individual failure. These risks can only be handled adequately on a collective level. The taking of collective responsibility for social risks is the second foundation of the welfare state. Managing the risks of poverty, sickness or unemployment, or as Beveridge (1942) called them, the 'five giant evils' of Want, Disease, Ignorance, Squalor and Idleness, requires a collective effort. These collective efforts boiled down to risk management through public systems of social insurance, health care, education and housing in the socio-economic systems of organised capitalism that together make up the third and final foundation of the welfare state.

Since the 1970s, however, the welfare state has constantly been 'in crisis. On the one hand, this crisis is the result of the gradual transformation of western economies towards a post-industrial, service-based knowledge economy and on the other hand the result of the accompanying processes of globalisation and individualisation. These economic and social transformations affect the fiscal basis of the welfare state and the institutional capacities of the welfare state to manage social risks collectively and affect public support for the welfare state as well.

This book investigates the consequences of changing social and economic conditions, defined in terms of individualisation and globalisation, for the social foundations of the welfare state. The literature on changing welfare states often focuses on processes of policy change and the mechanisms that cause or block these changes (Esping-Andersen 1990, Pierson 1994, Streeck and Thelen 2005, Steinmo, Thelen and Longstreth 1992). Path dependency, veto-points and processes of increasing returns are the mechanisms used to explain these impediments to change. The actual change observed is often interpreted as resulting from external crises that open up avenues for change (Hall 1993) or as the result of more gradual processes of policy change (Hacker 2004). In this book we take a different perspective and turn to theories and processes of social change that are hypothesised to have important consequences for the social foundations of the welfare state. Our perspective is of a more sociological nature.

In sociology, it is the 'logic of industrialism' (Skocpol 1990) that produced the modern welfare state. From this perspective, the social problems and the functional prerequisites of an industrial society are responsible for the birth of the welfare state. Institutional differences in 
the administrative make-up of nation states and in the arrangement of the political system consequently explain the differences between existing welfare states (Evans, Rueschemeyer and Skocpol 1985; Skocpol 1990; Korpi 1983). However, the 'logic of industrialism' has been replaced by a 'logic of post-industrialism, which is the focus of our investigation in this book. As suggested above, the social and economic changes that result from the transition towards a post-industrial society have weakened the social foundations of the welfare state (Offe 1985; Lash and Urry 1987). In this book we will examine this claim.

We do this by asking three questions central to understanding the social foundations of the welfare state. This first concerns the manifestation and perception of risks. The question is whether social risks are changing and whether they are still perceived as risks that deserve collective attention. The second question concerns the willingness to share risks. Are people still willing to take some responsibility for others through solidaristic arrangements or do processes of individualisation undermine the previous foundations of solidarity? We turn thirdly to the issue of risk management and policy change. When people are still willing to share risks, how is this translated into a strategy of risk management and into welfare state policies?

We investigate the social foundations of the welfare state with all the actors that play a role in the institutions of the welfare state: the nation state, employers and employees, firms and unions, citizens and political parties. We expect to find the following changes in the perception of social risks and in the willingness to share risks. First, sociological theory predicts that individualisation and globalisation will produce (new) social risks which are of a less collective nature or will be perceived in a less collective manner. This will, secondly, gradually undermine the social solidarity on which the welfare state is based. When, thirdly, the perceptions of risks and the willingness to share risks of the involved participants change, this will gradually influence the policies they develop, support and implement to deal with these risks. As a consequence, the social foundations of the welfare state are changing.

This book is based, in part, on research about (changes in) the opinions of different actors. But we have also researched actual processes of risk sharing and risk management in different contexts. Our research focuses thus mainly on the hypothesised consequences of individualisation and globalisation for risk perception, the willingness to share risks and risk management. We investigate these consequences and consider what they mean for the social foundations of the welfare state and the possible shift towards a new welfare settlement in the $21^{\text {st }}$ century. 
The research on which this book is based was carried out predominantly in the Netherlands. In addition, the research presented here represents work from numerous research projects executed by a research team at the Erasmus University in Rotterdam, the Netherlands, projects which are part of a larger research programme on Labour, firms and social security, financed by the Dutch Gak Foundation (Stichting Instituut Gak).

\section{References}

Baldwin, P. 1990. The Politics of Social Solidarity: Class Bases of the European Welfare State 1875-1975. Cambridge: Cambridge University Press.

Beck, Ulrich. 1992. Risk society: Towards a new modernity. London: Sage Publications.

Beck, Ulrich and E. Beck-Gernsheim. 2002. Individualisation. London: Sage Publications.

Beveridge, W.H. 1942. Social Insurances and Allied Services. London: HMSO.

Bonoli, Giuliano. 2004. "The politics of new social risks and policies." Presented at the ISA conference RC 19, September 2004, Paris.

Cantillon, Bea, Mark Elchardus, Pierre Pestieau and Philippe Parijs, eds. 2003. De nieuwe sociale kwesties (The new social problems). Antwerp: Garant.

Esping-Andersen, Gøsta. 1990. The Three Worlds of Welfare Capitalism. Cambridge: Polity Press.

Evans, P.B., D. Rueschemeyer and T. Skocpol. 1985. Bringing the State Back In. Cambridge, Massachusetts: Cambridge University Press.

Hacker, Jacob. 2004. "Privatizing Risk without Privatizing the Welfare State: The Hidden Politics of Social Policy Retrenchment in the United States."American Political Science Review 98(2): 243-260.

Hall, Peter. 1993. "Policy paradigms, social learning and the state: the case of economic policy making in Britain." Comparative Politics 25(3): 275-296.

Korpi, Walter. 1983. The Democratic Class Struggle. London: Routledge and Kegan Paul.

Lash, S. and J. Urry. 1987. The End of Organized Capitalism. Cambridge: Polity Books.

Offe, Claus. 1985. Disorganized Capitalism. Cambridge, Massachusetts: M.I.T. Press. 
Pierson, Paul. 1994. Dismantling the Welfare State? New York: Cambridge University Press.

Skocpol, Theda. 1990. Social Policy in the United States: Future Possibilities in Historical Perspective. Princeton: Princeton University Press.

Streeck, Wolfgang and Kathleen Thelen. 2005. Beyond Continuity. Institutional change in advanced political economies. Oxford: Oxford University Press.

Steinmo, S.H., K. Thelen and F. Longstreth. 1992. Structuring Politics: Historical Institutionalism in Comparative Analysis. New York: Cambridge University Press.

Taylor-Gooby, Peter. 2004. New Risks, New Welfare. The Transformation of the European Welfare State. Oxford: Oxford University Press.

Taylor-Gooby, Peter. 2011. Does risk society erode welfare state solidarity? Policy and Politics, 39-2: 147-161. 



\title{
1 Risk and the Welfare State
}

\author{
Risk, Risk Perception and Solidarity
}

Romke van der Veen

In this chapter we give a short summary of the literature on changing risks and the welfare state. The welfare state is presented here as an institution which deals with the social risks of an industrial society. Organised social solidarity, institutionalised in the provisions of the welfare state, are used to cope with the social risks of an industrialised society. It is often argued that the social solidarity of the welfare state is being eroded. New risks, a new logic of risk production, and a new risk culture are undermining the social foundation of welfare state solidarity. The changes in risks, risk production and risk culture are attributed to social and economic change, which resulted from the transformation towards a post-industrial society. Individualisation and globalisation are the key processes in this transformation. In this book, we investigate whether risk perception is changing and whether this undermines welfare state solidarity. Changes in risk perception and in solidarity will affect the way risks are dealt with. This is the third issue on which this book focuses: the changing nature of risk management in post-industrial society. We do not simply expect to see an erosion of solidarity. Therefore we want to investigate how changes in risk perception and solidarity affect the welfare settlement and whether a new welfarism, as is often suggested, is coming into existence.

\section{Introduction}

The welfare state and its programmes of social insurance and social protection are intended to deal with the risks encountered in the typical life-course of a worker in an industrial economy: the risks of unemployment, disability and old age. However, processes of individualisation and globalisation that are part and parcel of a transformation towards a 
post-industrial society have revolutionised social and economic relations. The transformation towards a service-economy goes hand-in-hand with a change in cultural values in the direction of a so-called post-materialist culture. This implies a switch from materialist values, emphasising economic security, to post-materialist values emphasising autonomy and self-expression (Inglehart 1977).

It is often suggested that these social and economic developments undermine the foundations of the welfare state (Taylor-Gooby a.o. 1999, 2011). The welfare state is based on a notion of social solidarity that bridges social divisions between classes, solidarity that binds the fates of the lower and the middle classes, the poor and the rich, the young and the old and the sick and the healthy together in welfare programmes based on risk-sharing between high- and low-risk categories. Economic and social processes of globalisation and individualisation are thought to weaken these bonds of solidarity between different social groups and to undermine the willingness of people to support each other in times of bad luck.

In this book we investigate whether people's understanding of risk has changed in ways that undermine the social foundations of the welfare state. To do this, we must first consider the perception of risks. The question is whether risks encountered by workers are still perceived as social risks. Social risks are risks that do not result from individual choice but are (also) produced by the social system of production. Social risks deserve collective attention because they can only be handled collectively, for example by the firm or the state. The social foundation of the welfare state concerns, secondly, the willingness to share risks. The question we ask is whether people are still willing to take (some) responsibility for the fate of others through welfare state arrangements based on solidarity or whether the changing perception of risks undermines the willingness to share these risks. Finally, we investigate the issue of risk management and policy change. When people are willing to share risks, how is this translated into a strategy of risk management and into welfare state policies?

In this introductory chapter we will elaborate on these questions, but first we consider the role of risk, risk perception and the willingness to share risks in the development of the modern welfare state. In the sections that follow, we will subsequently discuss three different, but related approaches to the sociological development of risks and the consequences of these developments for the perception and willingness to share risks. In section three we discuss the social and economic developments towards an open society and an open economy: individualisation and globalisation. In section four we discuss the idea of a risk society as developed by 
Luhmann, Beck and Giddens. In section five we discuss the idea of new social risks. Following these discussions, we consider what these developments mean for the management of social risks in section six. Finally, in section seven, we outline the remaining chapters of the book.

\section{Social risks and the welfare state}

The welfare state can be seen as a solution to the problem of coping with the risks workers encounter in everyday life. As such, the welfare state is a product of industrial society. Industrial society produced (new) risks such as occupational disability and unemployment and at the same time, existing risks such as poverty, old age or sickness were seen through a new lens of institutions associated with industrial society, such as factories and cities.

In industrial society risks gradually came to be seen as social risks and not as individual problems. Unemployment, occupational disability and industrial accidents were increasingly perceived as unavoidable (system) risks produced by the industrial economy and industrial production processes and not as a result of individual failure (Schwitters 1991). This fuelled a dynamic collectivisation of these risks.

The dynamics of the welfare state as a system through which people share socially produced risks and thus take (some) responsibility for each other is best illustrated in the system of social security. This dynamic is characterised by a collectivisation of social insurance, increasing comprehensiveness of risk protection and the increasing coerciveness of social insurance programmes (De Swaan 1989). Social insurance (for unemployment, disability, sickness, healthcare) is based on the actuarial notion of calculable risks. As such, markets can produce social insurance. But these markets are plagued by problems of adverse selection relating to the exclusion of high-risk categories (for example the elderly or the sick) from social insurance, and by free rider problems that limit the comprehensiveness of social insurance. These problems have caused the state to intervene in social insurance markets in order to create more comprehensive systems of social insurance than markets can produce. Unless insurance is, to some extent, made to be compulsory and in the absence of an obligation for insurance companies to accept all individuals, social insurances would be (too) socially selective.

Systems of social insurance are systems of (compulsory) risk sharing. High-risk and low-risk categories are brought together under the same 
insurance in order to carry the total costs of damage experienced by the insured group. Risk-sharing between high- and low-risk categories creates solidarity: solidarity between young and old or between the healthy and the sick. This solidarity is formal and detached, which means that it is the enforced product of a (comprehensive) system of social insurance.

Other parts of the social security system, social assistance for example, can also be characterised as programmes through which people take responsibility for each other. However, need, not risk, is the central category around which these programmes are organised (Kemshall 2002). This type of responsibility-taking organises solidarity between the haves and the have-nots; it organises solidarity around society's most vulnerable groups and individuals. Need-based solidarity in social assistance is as formal as the solidarity organised in social insurance systems because social assistance in a welfare state is financed using general fiscal revenues.

As welfare states developed, the dynamics of the collectivisation of social risks produced increasingly universal programmes. The dynamics of collectivisation can explain why social insurance has become increasingly universal. However, it cannot explain why social insurance, or welfare state programmes in general, came into being. This question is answered by Baldwin in his book The Politics of Solidarity (1990) in which he describes the forces that gave birth to the modern, universal welfare state. In the first place, these forces are economic ones. The programmes of the welfare state, for example, social insurance, housing and health care, fulfil an economic function in the sense that they contribute to the optimal functioning of the economy. But this is not nearly enough to create a universal welfare state. The second mechanism that contributed to this is the political process in which the legitimacy of the modern state is produced. By developing a welfare state, the nation state attempted to organise its own legitimacy, as Bismarck tried to do when he introduced social insurance in Germany in the nineteenth century. But again, this mechanism is not nearly enough to explain the birth of the modern universal welfare state. A third and important mechanism is what Baldwin calls the logic of social interests. One needs the support of the middle class to develop a broad welfare state. Therefore, coalitions of both working class and middle class parties lie at the foundation of broad, universal welfare states in which welfare state programmes not only cater to the working class but also to the middle class. Finally, administrative factors play a role in this development. The history and administrative capacities of nation states can limit or fuel the development of a universal welfare state. 
Hence, the welfare state that developed in industrial society is a complex system of services and provisions, from health care and education to housing and social security. First and foremost, this system of services provides citizens with social security, ranging from income support when needs are not met by the market, to housing subsidies when housing is too expensive. Secondly, and to a certain extent, the welfare state equalises life chances through meritocratic education policy or universal health care services. Thirdly, the welfare state promotes social integration, that is, participation in dominant social institutions. The services and provisions of the welfare state facilitate social integration, for example through education or labour market participation, but social integration is also produced by the obligations that always accompany social rights. Rights to housing, education, health care or social security are matched by obligations to pay taxes, to work, and more generally, to conform to the social norms embedded in dominant social institutions. Thus the welfare state is also a disciplinary state.

When we define the welfare state as an institution that provides social security, equalises life chances and promotes social integration, this definition implies that the welfare state is much more than an institution that protects the vulnerable and the needy (Goodin 1985, 1988). What distinguishes the welfare state of the twentieth century from nineteenthcentury poor laws and the first social security laws, is the fact that it provides services and provisions to all, not only to the poor. The growth of the welfare state in the twentieth century, especially during 'the golden age', was made possible by conditions of stable nuclear family structures and economic stability, resulting in stable employment and high levels of family-wage employment. National governments were able to manage their national economies through neo-Keynesian policies, policies based on a political coalition between the working and middle classes that favoured state action for managing the economy as well as the organisation of social services and provisions (Taylor-Gooby 2004: 1-2).

As noted above, since the golden age of the welfare state, the social and economic context of welfare states has changed fundamentally. These changes can be expected to affect the perception of risks, the willingness to share risks and consequently the management of social risks. In the next three sections we will discuss risk perception and risk sharing from three different perspectives. We will investigate the possible consequences of processes of individualisation and globalisation on the perceptions of risks and the willingness to share risks. In addition, we will turn to the idea that the welfare state has become a risk society as a result 
of processes of globalisation and individualisation, which has led to the birth of a new 'risk culture'. The perception of risks and the willingness to share risks is fundamentally different in a risk society as compared to a traditional welfare state. We also consider the concept of new social risks. Once again, new social risks become manifest as a result of processes of individualisation and globalisation. New social risks differ fundamentally from old social risks and this is expected to affect the perception of these risks as social risks as well as the willingness to share these risks and the management of these risks. Having sketched the possible developments concerning risk perception and risk sharing, we turn to the expected consequences of these developments for the management of social risks. Risk management strategies of the old welfare state - redistribution and universal services - are expected to give way to a new welfarism that is characterised by investment in human capital and the enhancement of individual opportunities.

\section{Individualisation and globalisation}

The welfare state is the product of the long-term processes of collectivisation of both risks and responsibilities. These processes of collectivisation took place within the context of an industrial economy and alongside the evolution of nation states and Fordist firms. These processes were favourable to the birth of the welfare state. In the last quarter of the twentieth century, however, these conditions changed. According to Anthony Giddens $(1980,1994)$ for example, the process of social and economic modernisation first facilitated the evolution of the welfare state but is nowadays undermining the social foundations of the welfare state. This weakening of the social foundations of the welfare state is the result of two developments. The first is a political and economic development towards an open economy; the second is a related social and cultural development towards an open society. The first is associated with processes of globalisation, the second with processes of individualisation.

To start with the latter, individualisation concerns the freedom of individuals to organise their own life as social relationships become less intense and coercive. Individualisation is operationalised sociologically along different lines. First, it is operationalised in terms of changing values. In this manner, so called post-materialist values, with a focus on individual freedom and self-expression, become increasingly important (Inglehart 1977). Secondly, individualisation is operationalised in terms 
of changing dependencies between individuals. Individualisation implies a loosening of the ties between individuals. The social bond becomes less coercive and, following Durkheim, this implies an increase in individual freedom (Putnam 200o). Thirdly, individualisation is operationalised as increasing social reflexivity: "... individuals (...) become used to filtering all sorts of information relevant to their life situations and routinely act on the basis of that filtering process" (Giddens 1994: 6). Individualisation defined as increasing social reflexivity therefore concerns increasing choice and knowledge and implies what Giddens calls 'detraditionalisation', whereby the role of tradition is replaced by knowledge.

Globalisation, on the other hand, has to do with increasing social and economic mobility (Urry 2007). Giddens defines globalisation as 'action at distance': "Our day to day activities are increasingly influenced by events happening on the other side of the world. Conversely, local lifestyle habits have become globally consequential" (Giddens 1994: 5). Globalisation has two faces. On the one hand, it destroys boundaries between localities and as such, it contributes to the process of individualisation because it increases individual freedom of choice. On the other hand, it creates new bonds between distant actors as they become increasingly interdependent within a global network.

Globalisation and individualisation open up national economies and societies. The welfare state is built around the nation state, which makes it vulnerable to processes of globalisation. Economies are organised and controlled within the territorial boundaries of nation states. Globalisation can diminish the institutional capacities of national states, thereby undermining the fiscal foundation of welfare states as capital and financial markets become increasingly global and mobile. Individualisation is likewise a possible threat to the welfare state. Shared risks, shared preferences and shared fates are the social foundation of the welfare state. When these shared understandings fade away, it is possible that the perception of risks as social risks as well as the willingness to share risks collectively will diminish. This diminished willingness to share risks collectively can be the result of a shift towards post-materialist cultural values, but can also be the result of what Giddens terms the rise of manufactured risks, that is, risks that are produced by the reflexivity of social institutions. Both processes stimulate a perception of social risks as being the result of (individual) choice. Consequently, this perception of social risks can diminish either the willingness to share risks or the way in which risks are managed, for example by paying greater attention to the choices people make and trying to influence these choices. 


\section{Risk society, risk syndrome and the willingness to share risks}

The idea of changing social risks and changing risk perceptions not only plays a central role in the debate about the welfare state; in sociology, the notion of risk and the social manifestation of risks is also discussed on a more fundamental level. We now turn to this discussion about risks and the risk society.

What do we mean by the concept of risk? In general, the risk of a certain event, for example the risk of occupational disability, is the probability of a dangerous event such as an industrial accident, multiplied by the amount of expected damage connected to this event, the loss of income (Bora 2007). This information-theoretical concept of risk is the concept used by insurance companies. The extent of risk, then, is a question of complete or incomplete information. Risk is therefore opposed to certainty (Blom and Nijhuis 1996: 278). Risk management has to do with acquiring as much information as possible regarding risk probability and damage. This probabilistic concept of risk is at the heart of the economic model of rational action on which actuarial science is founded, the science on which (social) insurance is founded.

Next to the information-theoretical concept of risk, a decision-theoretical concept of risk can be distinguished. This decision-theoretical concept of risk was developed by Luhmann (1991). For Luhmann, risks have to do with actions and decisions that can have future consequences. In other words, risk is caused by social decisions. Risks are entered into, dangers we undergo (Blom and Nijhuis 1996: 278). Risk, as well as danger, is uncertain, but risks are the consequences of choice and social action whereas danger can be attributed to the (external) environment, to nature. According to Luhmann, modern society is a risk society. The combination of increasing social complexity and increasing choice creates a greater number of risks. Increased complexity also creates an increase of risk because complexity intensifies the possibility that (unintended) interferences between actions and the environment will occur. According to Luhmann, modern society is therefore characterised by its risk culture. He even speaks of a 'risk syndrome', which makes people extremely aware of and averse to risks.

Related to the distinction between the information-theoretical and decision-theoretical concept of risk is the distinction between objective and subjective definitions of risks. The traditional information-theoretical concept of risk is based on an objective notion of risk. Luhmann's 'sociology of risk', on the other hand, is about subjective perceptions of risk and a risk syndrome, which is an exaggerated sensitivity to risks. 
Luhmann's sociology of risk is directly related to the notion of the risk society, as introduced by Ulrich Beck (1986). Central to Beck's concept of the risk society is the notion of reflexivity. The institutions and technologies of modern society have developed to a point where we are increasingly confronted with unintended technical and social consequences, such as pollution and welfare dependency. Initially, during the first phase of modernisation, institutions and technologies facilitated (social) control - for example the social control of risks. But as social control increased, unintended consequences increased as well. These unintended consequences were reinforced by ongoing processes of individualisation and globalisation. Modernity has therefore entered a second phase in which the (negative) unintended consequences of institutions and technologies overshadow the (positive) intended consequences. This second phase is called reflexive modernity, or second modernity, which is characterised by a loss of control and a loss of faith in the beneficial workings of institutions, technologies and expert knowledge.

In Beck's notion of the risk society the negative consequences of technology and institutions, for example nuclear fall out, environmental pollution, or the decreased efficiency of the welfare state, overshadow the positive consequences. In this respect, Beck differs fundamentally from Luhmann because Luhmann's conceptualisation of risk is led by a more subjective notion of a risk culture and the idea of a risk syndrome, whereas Beck concentrates on objective changes in risks.

In the theoretical discussion about risk, Taylor-Gooby and Zinn (2006:

12) observe (among others) the following trends:

- a rapid expansion of interest in and awareness of risk;

- a shift from a reliance on expert perspectives to much greater recognition of the independent value of lay perspectives in the understanding of risk;

- an associated move from rational actor approaches to more socially informed approaches;

- a shift away from approaches directed at the elimination or reduction of risk towards interest in the management of risks as they can be identified;

- new policy approaches which empower individuals as the responsibility for coping with risks shifts from the state to citizens, which runs parallel to a greater sophistication in identifying risk factors and a greater sophistication in regulating and governing particular groups. 
These developments represent a shift towards a more decision-theoretical and subjective interpretation of the notion of risk. And this is where the sociological discussion on risk and discussions on changing welfare states overlap. The notion of a risk society, as developed by Luhmann, Beck and Giddens, suggests that risks are increasingly perceived as internal, or manufactured risks. This perception can undermine the willingness to share risks. But, following Luhmann, this change in perception does not necessarily lead to decreased support for risk sharing. The hypothesis that support for risk sharing is diminishing dominates the debate on changing welfare states and is supported by Beck. But Luhmann's idea of a risk syndrome suggests that people experience risks more intensively and therefore seek protection for these risks, which, on the contrary, might increase support for risk sharing.

\section{$5 \quad$ New social risks}

In Beck's notion of a risk society, both the subjective perception of risks and the objective manifestation of risks are changing. This idea of objective transformations in the character of social risks is also present in the debate on social risks and the welfare state. This is the debate on so-called new social risks (Taylor-Gooby 2004), or risks more commonly associated with a post-industrial economy. The question, then, is whether the risks people encounter in a post-industrial economy and an individualised society can be compared to the risks people experienced in traditional, industrial economies, and if not, whether this justifies the creation of different social welfare services and provisions (Kemshall 2002).

Three approaches can be distinguished in the discussion on new social risks. The first approach observes a different manifestation of social risks in post-industrial society. Traditional risks such as unemployment and old age are replaced by new social risks, risks often centred on work-life arrangements (Esping-Andersen 2000). Within this approach, Bonoli (2004) defines new social risks as situations in which individuals experience welfare losses, which have arisen due to socio-economic transformations, including most importantly, the growth of service sector employment and the large number of women that have entered the labour market. These new social risks are the result of a combined effect of family and labour market events and tend to affect (low-skilled) younger people, families with young children and working women. Bonoli distinguishes the following new social risks (2004: 4-5): 
- reconciling work and family life: the increasing participation of women in the labour market has undermined the traditional division of labour within families. Domestic work and childcare therefore often need to be externalised. An inability to reconcile work and family life can lead to a risk of poverty, especially for lower-income households.

- single parenthood: changes in family structures have resulted in increased rates of single parenthood. Single parents face greater difficulties in reconciling work and family life, which again creates an increased risk of poverty.

- having a frail or elderly relative: the massive entry of women into the labour market not only necessitates the externalisation of childcare but also the externalisation of elderly care and care for disabled family members. This development can also result in important welfare losses.

- possessing low or obsolete skills: in a post-industrial economy, lowskilled individuals are most often employed in the service sector. These services provide little scope for increases in productivity. Employment in this low value-added sector comes with a higher risk of poverty, in part if no minimum wage is guaranteed, but also due to the considerably higher risk of unemployment associated with service sector work.

- insufficient social security coverage: social security coverage in most European welfare states, notably pension schemes, is still based on notions of traditional, full-time, continuous employment that starts at an early age and includes a salary that grows over time. New career profiles and the massive occurrence of part-time work may result in new risks of poverty for (older) people.

A related but nevertheless different approach to new social risks is used by Elchardus (2003). He states that in a knowledge economy risks concentrate with specific vulnerable groups and that these risks have become more predictable. The combination of an increased concentration and predictability of risks with welfare programmes that increasingly expect individuals to act more responsibly, to be employable and to take more initiative, undermines the solidarity on which welfare programmes rest. It is those individuals who have the most difficulty meeting these new expectations that run the highest risk of welfare losses. A new social cleavage is created between those capable of meeting the new expectations and those who are not. This is mainly a cleavage between the high and the low educated. 
The third approach to new social risks has already been mentioned - the idea of manufactured risks: due to increasing knowledge and (individual) choice, social risks become manufactured risks. On the one hand, manufactured risks are the product of choices and lifestyles because choice and lifestyle can affect individual health, making the risk of sickness and disability to a certain extent a manufactured risk. On the other hand, manufactured risks are the product of individuals' willingness to learn and adapt. Their 'employability' is dependent on this and so are (to a certain extent) their labour market chances. In this sense unemployment can be viewed as a manufactured risk as well.

The changing character of social risks can affect the willingness of people to share risks. Esping-Andersen (2000), Bonoli (2004) and Elchardus (2003) all point to the fact that the categories of people who are affected by new social risks are often the politically weakest categories, individuals often not mobilised by trade unions. Following Baldwin's earlier mentioned logic of social interests, this lack of mobilisation will undermine the forces that support universal social security coverage. The hypothesis of diminishing willingness to share risks is also supported by power resource theory (Korpi 1985), which explains welfare state development from a perspective of how power is distributed among different social groups. New social risks tend to concentrate with the weakest social groups, groups traditionally not mobilised by unions, such as young workers and women. As a result, insider/outsider problems manifest themselves between traditional union members and the groups affected by new social risks.

Having discussed the different perspectives on risk perception and risk sharing we now turn to the issue of risk management. We expect that the changes sketched in the previous sections fuel fundamental changes in the way risks are dealt with. It is suggested that old welfarism, based on redistribution through social security and universal services, is giving way to a new welfarism based on notions of investment and inclusion.

\section{Towards a new welfarism?}

The changing character of risks affects the management of risks too. The welfare state is an institution that is meant to protect against and control risks. Within the welfare state, the traditional solution to risk management is to provide citizens with social security. But risk management can also take place by investing in people's ability to deal with risks (Bonoli 
2004). Taylor-Gooby expects this strategy for dealing with social risks to become dominant. He defines this new welfarism as the notion that:

(...) economic globalization, labour market flexibility, more complex patterns of family life and the dissolution of traditional class structures require a new welfare settlement. Since full employment, redistribution and expensive universal services are no longer seen as feasible, the new welfarism can only justify social spending as investment in human capital and the enhancement of individual opportunities. Welfare states are all driven in the same direction by the imperatives of international competition. (Taylor-Gooby 1997: 171)

A welfare state that focuses on investment in human capital and the enhancement of individual opportunities is often called a social investment state (see, for example, Giddens 1998; Esping-Andersen 2001). Giddens still sees the social investment state as a welfare state, but as a welfare state in which public responsibility has changed from protective to preventative, in which public policies are directed at empowering people and communities and in which notions of 'positive welfare' prevail. In his book, The Transformation of the Welfare State (2002), Gilbert prefers to talk about the enabling state. Gilbert characterises the transformation towards an enabling state as a shift "... from the ideal-type Scandinavian model of social welfare to a market-oriented version, which is identified with the Anglo-American approach" (2002: 4).

Taylor-Gooby (1997) suggests that welfare states are unavoidably developing in the direction of a new welfare settlement characterised by the ideology of new welfarism. The logic of international competition requires a welfare state that is lean, flexible and suited to a post-Fordist, post-industrial economy. This perspective follows the so-called 'There is no Alternative' (TINA) approach: globalisation washes over local economies making the erosion of the welfare state inescapable.

The idea of new welfarism also fits Giddens' notion of manufactured risks. This perspective on social risks places more emphasis on individual responsibility in the manifestation of risks in comparison to the old welfarist notion of risk, which focuses on the collective and systemic character of risks. Giddens' new welfarism is characterised by prevention and 'positive welfare'. On the one hand, policies directed at prevention are meant to influence the choices people make. On the other hand, positive welfare refers to all kinds of policies that invest in people in an attempt to make them better equipped to deal with risks. Both Taylor-Gooby and 
Giddens contend new welfarist policies to be better equipped to deal with new social risks. Given the earlier mentioned tendency towards diminishing support for risk sharing, the question is, however, whether the ideology of new welfarism is also affected by this process of diminishing solidarity.

The idea behind the 'new welfarism' thesis is that changing social problems make fundamental changes in social policies inevitable. The obvious rebuttal against this TINA argument is the fact that national welfare trajectories remain very distinct; in other words, politics still appear to make a difference. The continued importance of national politics suggests that new welfarism, or the 'logic of international competition', is just as politically mediated as the 'logic of industrialism' was. After all, the logic of industrialism produced distinctly different welfare states and the logic of international competition can likewise affect various welfare states in different ways. Therefore the conclusion must be that although a tendency towards 'new welfarism' may exist, it does leave room for alternative developments. However, this is highly dependent on the strength of the logic of international competition. The strength of this logic is probably most dependent upon the extent to which economic sectors are exposed to international competition. Employers, unions and workers in exposed sectors are much more concerned with containing upward pressure on labour costs than their equals in sheltered sectors are (Katzenstein 1985, Schwartz 1994, Clayton and Pontusson 1998).

The reversal of the TINA argument, which predicts unavoidable changes in risk management in the direction of new welfarism, is that despite changing conditions, little change is to be expected. According to Pierson (1996), the logic of increasing returns hinders fundamental change in welfare programmes, especially in the direction of retrenchment. Sunk costs and vested interests make it very difficult to organise political support for programmatic changes. Pierson predicts strong opposition to welfare state change, either from working-class parties or from groups with vested interests in existing welfare programmes.

However, we must take into account the fact that despite political opposition to restructuring and retrenchment, fundamental change is not to be excluded. As Pierson has argued (1994), programmatic change - that is, change that affects the content, level and range of social rights - is not easy to realise. Systemic change, however, change that primarily affects the administration, financing or implementation of programmes is easier to realise, and can have important programmatic consequences that are not directly visible, but manifest themselves in the long run. For example, 
systemic change in the organisation and political structure of social insurance in the Netherlands during the 1980 os enabled programmatic change during the 1990s (Van der Veen et al. 200o). More generally, Bonoli and Palier (1998) suggest that a first wave of welfare reform during the 1980s left social protection arrangements largely intact, but a second wave of reform during the 1990 s was more substantial. The interaction between systemic and programmatic changes made this substantial change possible.

The fact that although welfare states are to some extent change-resistant, this does not prevent change in the long run, was recently underscored by Streeck and Thelen (2005; see also Hacker 2004), who have introduced the notion of gradual change. In contrast to the dominant institutional theory of policy change, which sees many obstacles to policy change requiring external crises to make policy change possible, the authors observe many instances of policy change not produced by external crises but as a result of more gradual changes. Streeck and Thelen distinguish five institutional mechanisms that can bring about policy change independently of external crises. For example, policy change can take place when new institutions are introduced alongside older institutions, in this way preventing political opposition, or by introducing new practices within existing programmes that gradually take over the function of older institutions or mechanisms. These forms of change are the result of the mechanisms of layering and displacement. Policy change can also be the result of the strategic use of existing institutions to achieve new policy goals: drift and conversion. Finally, policy change can be the result of 'decreasing returns': the gradual collapse of existing institutions that makes policy change possible.

\section{The research and outline of the book}

Having sketched the sociological background to our research it is necessary to stress that this book is about risk perception and risk sharing and that we do not investigate processes of globalisation and individualisation and the manifestation of risks itself. Rather, we investigate the theoretically assumed changes that have taken place in people's understanding of risks as a result of these processes as discussed in the previous sections. In this book we analyse the perceptions various actors have regarding social risks, the willingness of these actors to share risks and thirdly, we investigate how risks are shared and managed in a variety of contexts. 
Our study is based on research into (changes in) the perceptions and opinions of different actors, but we have also researched actual processes of risk sharing and risk management in different contexts. The different research projects that make up this study have all been executed in the Netherlands.

This book attempts to answer three empirical questions:

- concerning risks:

1 What changes can be observed in the perception of social risks?

- concerning social solidarity (risk sharing):

2 What changes can be observed in the willingness to share risks? and

- concerning risk management:

3 Given these changes in social risks and social solidarity, what are the consequences for the management of social risks?

As far as risk perception and risk sharing are concerned, based on the literature we expect to find a diminishing perception of risks as social risks as well as a diminishing willingness to share risks. There is one exception in the literature: Luhmann predicts the development of a risk syndrome, which makes people increasingly risk averse, which in turn might stimulate individuals' willingness to share risks. Given the expected diminishing willingness to share risks, it is likely that risk management will become individualised and will be oriented towards prevention. The same consequences are to be expected in the development of social policies.

We start by investigating the perceptions of risks and the willingness to share risks. Chapters two and three analyse citizens' perceptions of social risks and their notions of social solidarity based on data collected in a large survey $(\mathrm{N}=2500)$ among Dutch citizens. Chapter two concentrates on welfare state support and Chapter three analyses how individualisation affects the perceptions of risks and the willingness to share risks. In Chapter four, we once again analyse the perception of risks and the willingness to share risks, but now based on a much more detailed investigation of temporary and flexible workers. We analyse, in particular, how their labour market position affects their opinions about social security. In the following chapters we turn from opinions and perceptions to practices. In Chapter five, the introduction of employability - a new form of risk management - is investigated within the context of firms and collective bargaining. Chapter six focuses on strategies of risk management in collective labour agreements and Chapter seven focuses on labour policies in transnational firms. We are also interested in the implementation of new strategies of risk management in the administration of social policy; 
therefore in Chapter eight we investigate the implementation of activation and labour market reintegration policies in a welfare agency. In Chapter nine, we bring the arguments developed in these chapters together in a final, concluding chapter.

\section{References}

Baldwin, P. 1990. The Politics of Social Solidarity: Class Bases of the European Welfare State 1875-1975. Cambridge: Cambridge University Press.

Beck, U. 1986. Risk Society. Towards a New Modernity. London: Sage.

Blom, T. and T. Nijhuis. 1996. "Risico en gevaar. Een blik op Luhmanns risico-sociologie." Tijdschrift voor Sociologie: 17(2): 275-288.

Bonoli, G. 2004. "The politics of new social risks and policies." Presented at the ISA conference RC 19, September 2004, Paris.

Bonoli, G. and B. Pallier. 1998. "Changing the Politics of Social Programmes: Innovative Change in British and French Welfare Reforms." Journal of European Social Policy, 8(4): 317-330.

Bora, A. 2007. "Risk, Risk Society, Risk Behavior and Social Problems." In The Blackwell Encyclopedia of Sociology. Ritzer, G. (ed.) Blackwell Publishers.

Cantillon, B., M. Elchardus, P. Pestieau and Ph. Parijs, eds. 2003. De nieuwe sociale kwesties (The new social problems). Antwerp: Garant.

Clayton, R. and J. Pontusson. 1998. "Welfare State Retrenchment Revisited: Entitlement Cuts, Public Sector Restructuring and Inegalitarian Trends in Advanced Capitalist Societies." World Politics 51(1): 67-98.

De Swaan, A. 1988. Care and the State. Cambridge: Polity Press.

Esping-Andersen, G. 2000. "A Welfare State for the 21st Century. Ageing societies, knowledge-based economies and the sustainability of European welfare states." Background report for the Lisbon Summit, EU.

- 2001. "A Welfare State for the Twenty-first Century." Pp. 134-156 in The Global Third Way Debate, edited by A. Giddens. Cambridge: Polity Press.

Giddens, Anthony. 1980. The Consequences of Modernity. Cambridge: Polity Press.

- 1994. Beyond Left and Right. The future of radical politics. Cambridge: Polity Press.

- 1998. The Third Way. Cambridge: Polity Press.

Gilbert, N. 2002. Transformation of the Welfare State. The Silent Surren- 
der of Public Responsibility. Oxford: Oxford University Press.

Goodin, R. 1985. Protecting the Vulnerable. A re-analysis of our social responsibilities. Chicago: Chicago University Press.

- 1988. Reasons for Welfare. The political theory of the welfare state.

Princeton: Princeton University Press.

Hacker, J.S. 2004. "Privatizing Risk without Privatizing the Welfare State:

The Hidden Politics of Social Policy Retrenchment in the United

States." American Political Science Review 98(2): 243-260.

Inglehart, R. 1977. The Silent Revolution. Princeton: Princeton U.P.

Katzenstein, P. 1985. Small States in World Markets. Industrial Policy in

Europe. Ithaca: Cornell University Press.

Kemshall, H. 2002. Risk, social policy and welfare. Buckingham: Open University Press.

Korpi, W. 1985. "Power resources versus action and conflict." Sociological Theory 3(2): 31-45.

Luhmann, N. 1991 Soziologie des Risikos. Berlin: de Gruyter.

Pierson, P. 1996. "The New Politics of the Welfare State." In: World Politics, 48(2): 143-179.

Putnam, R. 2000. Bowling Alone. New York: Simon and Schuster.

Schwartz, H. 1994. "Small States in Big Trouble." World Politics 46: 527-525.

Schwitters, R. 1991. De risico's van de arbeid: het ontstaan van de Ongeval-

lenwet 1901 in sociologisch perspectief. Groningen: Wolters Noordhof.

Streeck, W. and K. Thelen. 2005. Beyond Continuity. Institutional change in advanced political economies. Oxford: Oxford University Press.

Taylor-Gooby, P. 1997. "In Defence of Second-best Theory: State, Class and Capital in Social Policy." Journal of Social Policy 26(2): 171-192.

- 2004. New Risks, New Welfare. The Transformation of the European Welfare State. Oxford: Oxford University Press.

Taylor-Gooby, P. and J. Zinn, eds. 2006. Risk in Social Science. Oxford: Oxford University Press.

Urry, J. 2007. Mobilities. Cambridge: Polity Press.

Van der Veen, R., W. Trommel and B. de Vroom. 200o. "Institutional Change of Welfare States. Empirical Reality, Theoretical Obstacles." Pp. 33-54 in Government Institutions: Effects, Changes and Normative Foundations, edited by H. Wagenaar. Dordrecht: Kluwer. 


\section{Contested Solidarity}

\section{Risk Perception and the Changing Nature of Welfare State Solidarity}

Romke van der Veen, Peter Achterberg and Judith Raven

Social solidarity is one of the central pillars of the welfare state. In this chapter, we investigate to what extent the welfare state is supported by public opinion. We see support for the welfare state as an important indicator of social solidarity. First, we investigate whether welfare state support is diminishing, as is often suggested. We find that in reality, welfare state support is not decreasing. Rather, it has been constant or has even increased during the last ten to fifteen years. Given the fact that welfare state policies are changing, what does this high level of welfare state support mean? Does it mean the public opposes the retrenchment taking place in social policies, or does it mean the public supports these changes? To answer these questions, the second part of this chapter focuses on investigating the nature of social solidarity: Under which circumstances and with whom are people willing to share risks? We try to answer this question by investigating how people think about social risks, about deservingness and about the normative foundations of social policy. Our conclusion is that the welfare state is still firmly supported by public opinion because the developments in social policies are in line with developments in public opinion. Both are developing in the direction of increased conditionality and obligatory reciprocity.

\section{Support for welfare state (reform)}

It is often argued that developments in Dutch public opinion are diametrically opposed to the direction in which Dutch welfare policy is changing. Research from the Netherlands Institute for Social Research (Sociaal Cultureel Planbureau; SCP) demonstrates overwhelming welfare state support among the Dutch population and suggests that people more or less reject ongoing efforts to reform and retrench the Dutch welfare state 
(Becker 2005). Various authors have pointed to comparable circumstances abroad: high levels of welfare state support are accompanied by policies aimed at reform and retrenchment (Ringen 1987; Kaase and Newton 1995; Svallfors and Taylor-Gooby 1999).

Allegedly high welfare state support is also contrary to predictions in academia, which claim there is an emerging 'crisis of the welfare state'. Social scientists and economists have long argued that there are certain perverse mechanisms within the system that undermine the welfare state and its legitimacy (Murray 1984; De Swaan 1988; Hirschman 1980). Declining welfare state support is the supposed inevitable result of rising costs and increased claims on welfare state arrangements. However, these negative tendencies in welfare state support have not been observed empirically. Welfare state support in the Netherlands rose between 1975 and 2004 (from $71 \%$ to $91 \%$, compare to Becker 2005). In other European countries, the level of welfare state support is also notably high - as can be seen from research in Great Britain, Germany and Italy. An increase in support is discernable in these countries, as is the case in the Netherlands (Kaase and Newton 1995: 83).

However, this strong and increasing welfare state support needs to be re-examined. After all, the welfare state is not a stable subject: welfare state policies have changed considerably since the $198 \mathrm{os}$. When people are asked to give their opinion about the welfare state, the subject they are talking about is in constant flux. A question about welfare state support thus means something else in 1985 than in 2010, for example, because the welfare state in 1985 was different than the welfare state of today. Increasing levels of support are therefore likely to indicate a growing consensus about changes that have occurred across time. People are possibly supporting a new type of welfare state, one which is better suited to their ideas about an ideal welfare state.

In the Netherlands, the changes undergone by the welfare state during the past decades can be summarised by two developments. First, the Netherlands has witnessed a decrease in welfare expenditure, which is partly the result of the fact that the level of generosity of welfare arrangements has decreased. This means that the Dutch welfare state has retrenched over the years (Green-Pedersen 2002). At the same time, however, there has been a small increase in the share of people who support the welfare state. These observations combined lead us to hypothesise that welfare state support is in fact increasing because the welfare state is being retrenched. Table 1 shows the trends in welfare state support for the years 1981 to 2000 , controlled for expenditure and generosity. 
Table 1 Trends in support for the welfare state (correlations with year; 1981-2000;

Significance levels between brackets; one-sided tests for significance)

\begin{tabular}{lllll}
\hline & Correlation & $\begin{array}{l}\text { Controlled } \\
\text { for welfare } \\
\text { expenditure }\end{array}$ & $\begin{array}{l}\text { Controlled for } \\
\text { generosity }^{1}\end{array}$ & $\begin{array}{l}\text { Controlled for } \\
\text { welfare expenditure } \\
\text { and generosity }\end{array}$ \\
\hline $\begin{array}{l}\text { Welfare state } \\
\text { support }\end{array}$ & $0.58^{*}$ & -0.28 & $-0.70^{*}$ & $-0.73^{*}$ \\
$(\mathrm{n}=10)(\mathrm{years})$ & $(0.04)$ & $(0.27)$ & $(0.04)$ & $(0.05)$ \\
\hline
\end{tabular}

${ }^{1}$ controlled for unemployment and GDP; ${ }^{*} p<0.05$

Source: Cultural Changes in the Netherlands (1981-2000)

The table above shows that welfare state support is indeed increasing due to the changing nature of the welfare state. We see a significant increase in support for the welfare state between 1981 and 2000. Our conclusion is that people increasingly support the welfare state because the welfare state has been retrenched. We deduce this based on the significant decrease in support found when controlled for generosity. This means that if generosity had stayed the same from 1981 to 2000 , support would have decreased. In reality, generosity decreased, hence the rise in support. This means that large-scale reforms of social security have been, by and large, supported by the public (Achterberg, Van der Veen and Raven 2010).

Although this conclusion provides a striking contradiction in comparison to other literature on the subject, it is not very remarkable. For example, information on electoral support for parties that support neo-liberal policies (welfare retrenchment and less state intervention) shows that the public has generally become increasingly supportive of welfare state retrenchment (see Figure 1, next page). Support for parties that underscore a generous welfare state and more state intervention has gradually diminished (Achterberg 2006).

Our conclusion that the public increasingly supports the welfare state due to retrenchment would only be remarkable if electoral support for parties underscoring neo-liberal policies were to remain unmatched by equivalent support for welfare state retrenchment. In short, the discrepancy between public opinion and developments in actual policies may be smaller than is often suggested. 
Figure 1 Electoral popularity of neoliberal policy in the Netherlands from the 1970s onwards

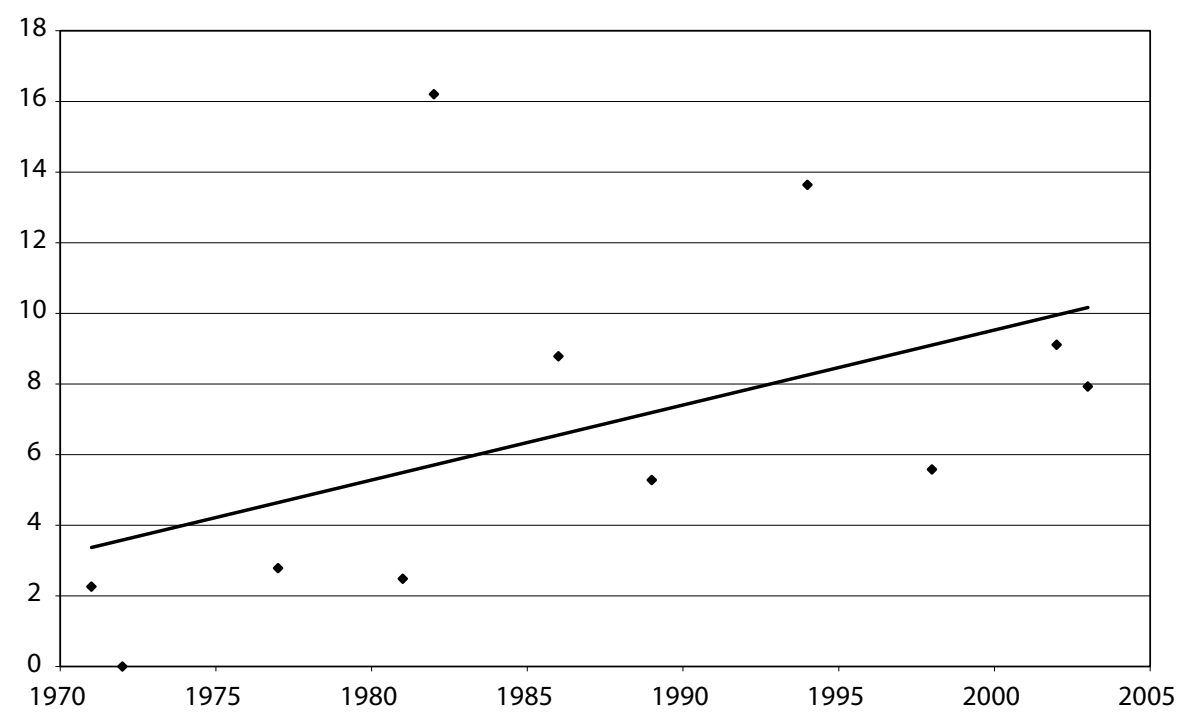

Source: Political Manifesto Data (Budge, Klingemann, Volkens, Bara, and Tanenbaum 2001)

\section{Public opinion on social security}

To research public opinion about social security, we carried out a survey among a representative sample of the Dutch population in 2006. Many of the questions we asked were the same as questions posed in a comparable, representative sample in 1995 (van Oorschot 1999). We asked respondents about support for various kinds of welfare arrangements and also about their motivations to support the welfare state. Social security arrangements are targeted at different social groups and public opinion demonstrates varying feelings towards different social groups in society. We investigated the support for four arrangements: social assistance, unemployment benefits, old age pensions and sickness/disability benefits. The next table (Table 2) shows the support for these four arrangements in 1996 and 2006. Support is measured by asking people whether they thought entitlements should stay the same, should decrease or should increase. We observe few significant changes between 1995 and 2006, although the support for an increase of entitlements rose between 1995 and 2006. Most important, however, is the fact that a large majority supports the arrangement and sees no need for change, in 1995 as well as in 2006. This again 
confirms our conclusion that people support the policy changes that have taken place in the Netherlands.

Table 2 Support for decreasing, increasing or stable entitlements to social security benefits $(1995 / 2006)$

\begin{tabular}{lcccccc}
\hline & \multicolumn{2}{c}{ decrease } & \multicolumn{2}{c}{ remain stable } & \multicolumn{2}{c}{ increase } \\
\hline & 1995 & 2006 & 1995 & 2006 & 1995 & 2006 \\
\hline $\begin{array}{l}\text { Social assistance } \\
\text { benefits }\end{array}$ & 14 & 13 & 58 & 53 & 28 & 34 \\
$\begin{array}{l}\text { Unemployment } \\
\text { benefits }\end{array}$ & 30 & 24 & 61 & 62 & 9 & 14 \\
$\begin{array}{l}\text { Disability benefits } \\
\text { Old-age pensions }\end{array}$ & 3 & 2 & 56 & 49 & 41 & 49 \\
\hline
\end{tabular}

Source: Tisser solidarity study, Tilburg University, 1995; Arbeid, Bedrijf en Sociale Zekerheid (Labour, Organization and Social Security), SIG/Erasmus University Rotterdam, 2006

In addition, we asked our respondents how they felt about four different aspects related to the recipients of these benefits. First, we asked about the degree of control respondents think beneficiaries have over their situation. For example, control over ageing is generally considered to be absent; individuals do not control whether they will become a beneficiary of old age pensions. However, this cannot be expected for other social security schemes; perhaps the public thinks people have a great deal of control over needing unemployment assistance. We expected that the more the public felt people were in control of specific risks, the less supportive public opinion would be of sharing these risks. In other words, if the public feels individuals are in control of social risks, they are likely to be less supportive of social security schemes that manage these risks. Opinion on control, that is the extent to which people are held responsible for being dependent on social security, has not changed and swings around the theoretical mean, meaning the respondents have no clear opinion on this either way (see Table 3). However, this varies when we look at different risks.

In 1995, 35 per cent of the Dutch public thought being employed was something an individual had under his or her own control; in 2006, this was 62 per cent. In terms of unemployment, in 1995, 13 per cent of the Dutch public thought unemployment was something an individual could control; in 2006, this rose to 26 per cent. Finally, perceived responsibility 
for being a single mother on welfare increased from 15 per cent in 1995 to 25 per cent in 2006. Second, we asked about trust: Do people think beneficiaries will act according to the rules of the welfare system? We expect that as trust in welfare beneficiaries increases, so will the support for social security schemes aimed at trustworthy beneficiaries. In general, our respondents think there is a lot of misuse, so trust is relatively low. Third, we asked about the level of identification with beneficiaries. Our idea is that the willingness to share risks collectively is more prevalent when benefits are targeted at individuals with whom the public identifies or shares similarities. This expectation is confirmed: our respondents are more willing to share risks with others with whom they identify. Lastly, we asked about the level of neediness: do our respondents think welfare beneficiaries really need welfare assistance? We expected that when people regard social categories as particularly needy, they will support welfare arrangements targeted at these categories. This relationship between need and support was confirmed as well, and even though many people think welfare beneficiaries misuse social security arrangements, they also think many of these beneficiaries really need social assistance. We found no major changes in these opinions between 1995 and 2006. The next table shows how the Dutch public thinks about control, trust, need and identity.

Table 3 Opinions about the norms of control, trust, need and identity in 1995 and 2006 in the Netherlands

\begin{tabular}{lcc}
\hline & 1995 & 2006 \\
& Mean (SD) & Mean (SD) \\
\hline Control (1-5) & $3.13(0.58)$ & $2.930 .65)$ \\
Trust (1-5) & $2.44(0.57)$ & $2.48(0.59)$ \\
Need (1-10) & $6.99(1.74)$ & $7.13(1.58)$ \\
Identity (1-5) & $3.61(0.85)$ & $3.56(0.94)$ \\
\hline
\end{tabular}

Source: Tisser solidarity study, Tilburg University, 1995; Arbeid, Bedrijf en Sociale Zekerheid (Labour, Organization and Social Security), SIG/Erasmus University Rotterdam, 2006

Next, using the concept of reciprocity, we analysed whether the public at large supports recent welfare reforms in the Netherlands. The level of reciprocity is basically determined by the balance between the rights and obligations of beneficiaries incorporated into a social security scheme. 
Following Mau (2003, 2004) we distinguish four types of reciprocity: generalised, balanced, risk, and obligatory reciprocity. If a scheme can be characterised by generalised reciprocity, it means the arrangement is generous and does not ask beneficiaries for much in return. Balanced reciprocity can be found in arrangements that are based on the principle of equivalence: the output is dependent on what people have contributed (the input). The more and the longer people have contributed, the higher their benefits will be. Risk reciprocity is based on the idea of a safety net, which is designed to help people who are likely to encounter certain social risks. The level of conditionality associated with a safety net is very limited, but this means that the actual level of the benefits is also rather limited. Obligatory reciprocity, finally, is based on a strict connection between social benefits and social obligations. There is strict monitoring of compliance with individual obligations. We find that the Dutch public increasingly thinks reciprocity in social security is important. We find some change in the way in which the Dutch public underscored these reciprocity principles between 1995 and 2006: support for the principle of obligatory reciprocity increased and support for the principle of generalised reciprocity decreased (Achterberg, Van der Veen and Raven 2010). ${ }^{1}$ This increase in support for obligatory reciprocity was matched by actual changes in public policy: as obligatory reciprocity is increasingly underscored by the public, public policy increasingly and more strongly incorporates these principles. The inevitable result is that support for social security arrangements based on obligatory reciprocity rises.

From this we can conclude that public opinion about the principles underlying social policies, together with developments in social policies, determine, to a great extent, whether the public at large supports social policy. This means that increasing support for a welfare state which is being retrenched essentially means something else than increasing support for a stable (in terms of expenditures and generosity) welfare state. In the latter, this would signify growing support for an extensive welfare state, whereas in the former it means the exact opposite. Therefore, it is important to study how the public at large supports welfare reform.

To that end, it is imperative to elaborate briefly on welfare state reforms. Welfare state reform is often discussed in terms of retrenchment (Pierson 1994) and recommodification (Gilbert and Gilbert 1989). When we look in more detail at the actual policies of welfare reform, four different but connected transformations can be observed (Gilbert 2002). The first major transition is privatisation, which basically entails less 
emphasis on the role of the state in delivering social protection and more on the role of the market and private organisations. Secondly, there is increasing selectivity, which implies a restriction of universal social rights to an ever-more select group of people in need of social and economic support (Pierson 1994). In this way, governments attempt to restrict support to those who really need it and to avoid giving social support to those who do not need it. Third, services are increasingly directed at activation in order to enhance labour market participation. In this way, dependency on welfare or social security is prevented. Finally, there is an increasing tendency to discipline those who are dependent on the welfare state. Rights to social security are increasingly combined with certain reciprocal obligations (Turner 1997; Van der Veen 2009). If people do not comply with these reciprocal obligations, they may be sanctioned, e.g. cutting benefits in order to coerce recipients into more desired behaviour.

A detailed analysis of support for these four processes of welfare reform shows that two latent, ideological dimensions can be found (see Table 4). The first dimension refers to support for redistributive reform; that is, reform that affects the redistributive effects of welfare state policies: in this case, retrenchment. The second dimension refers to support for reciprocal reform, that is: reform that affects the relationship between rights and duties in social policies: in this case, more obligations and thus more reciprocity.

Table 4 One ideology of welfare state retrenchment? (Factor analysis, using varimax rotation)

\begin{tabular}{llll}
\hline & $\begin{array}{l}\text { One dimensional } \\
\text { model }\end{array}$ & Two dimensional model \\
\hline Scale for privatisation & 0.38 & 1st factor & 2nd factor \\
Scale for selectivity & -0.24 & 0.28 & 0.59 \\
Scale for labour market activation & 0.84 & -0.17 & 0.81 \\
Scale for more discipline & 0.82 & 0.83 & -0.04 \\
Eigenvalue & 1.59 & 0.85 & 0.02 \\
R2 & 0.40 & 1.59 & 1.15 \\
$\mathrm{~N}$ & 1739 & 0.40 & 0.27 \\
\hline
\end{tabular}

Source: Arbeid, Bedrijf en Sociale Zekerheid (Labour, Organization and Social Security), SIG/ Erasmus University Rotterdam, 2006 
This table shows that both dimensions are independent of each other and that activation and more discipline belong to the same normative dimension (when people score high on the one, they also score high on the other), as do privatisation and selectivity.

These two types of support for welfare reform can be related to two types of beliefs regarding social justice: beliefs that emphasise distributive justice and beliefs that emphasise reciprocal justice. The former questions whether social rights are distributed in a just manner and the latter questions whether obligations are distributed in a just manner. The table above suggests that the opinions of respondents on these two types of social justice are independent of each other. In other words: people who support extensive redistribution in welfare policies do not necessarily oppose extensive obligations and a high level of obligatory reciprocity (or vice versa). Our research indicates that the Dutch public is more inclined to support reciprocal reform, that is, reform that increases the obligatory reciprocity between rights and duties. In Dutch social policy, this implies a strengthening of duties among those who receive benefits. However, support for and opposition to redistributive reform are evenly distributed. Redistributive reform is about increasing or decreasing the level of redistribution by means of the range or value of benefits. That the public at large is supportive of (obligatory) reciprocal reforms is mainly due to the fact that people with different ideological positions (both left and right on the political spectrum) are supportive of these types of policies. Above, we concluded that increased welfare state support can be explained by the way in which the welfare state itself has developed. Now we can refine our conclusion: support is particularly high because the public supports reforms of a more reciprocal nature that emphasise obligations. And, indeed, reciprocal reforms have occurred often in the Dutch welfare state during the past decades.

Finally, we studied ideas about justice by asking our respondents about the way in which they feel various social categories deserve financial assistance from the welfare state. Our research indicates that social categories are considered to be deserving if those social groups are perceived to be needy and cannot be blamed for their welfare dependency. For instance, individuals who become sick or the elderly are generally perceived to be the most deserving categories of welfare benefits. On the other hand, if people do not want to work, or have become unable to work because of something perceived to be their own fault, the public at large thinks they do not deserve much financial assistance (see Figure 2). 
Figure 2 Deservingness perceptions of the Dutch public

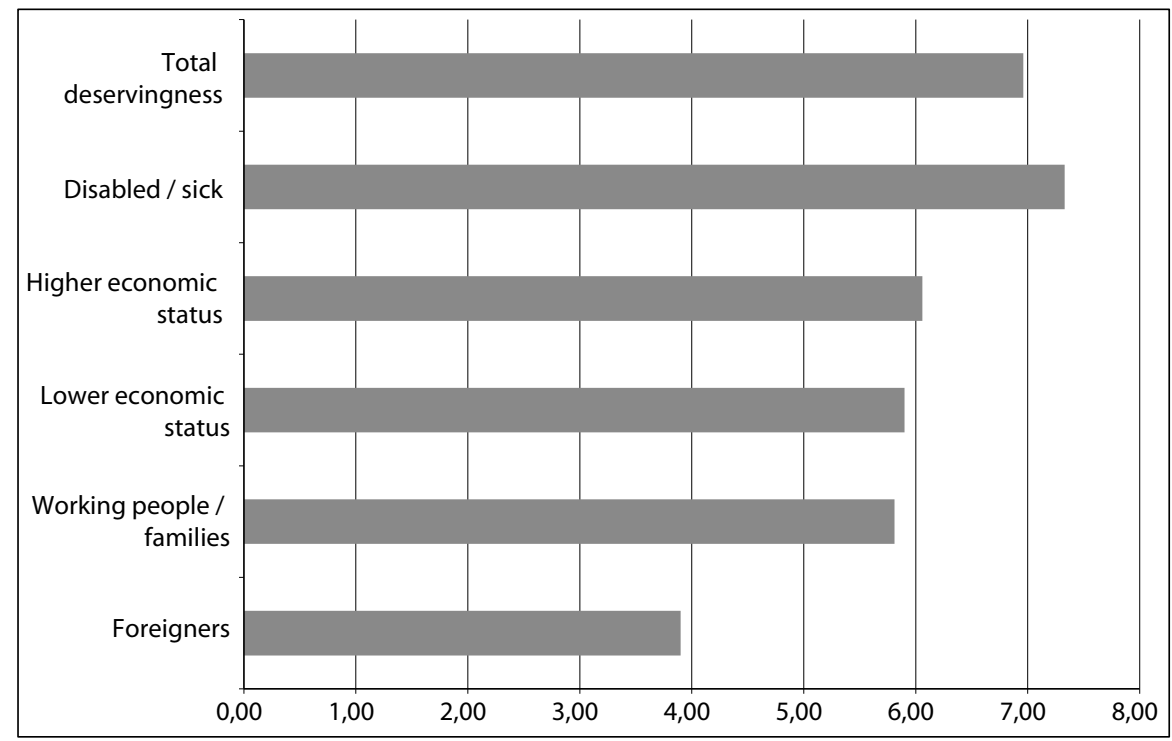

Source: Arbeid, Bedrijf en Sociale Zekerheid (Labour, Organization and Social Security), SIG/ Erasmus University Rotterdam, 2006

Our conclusion, based on the public opinion about social rights, the normative foundations of social policy and deservingness, is that welfare state support as such remains high. The Dutch public is not massively abandoning the welfare state. Some are more in favour of the welfare state than others, but welfare state support depends upon the type of policy being investigated as well as the social categories being targeted by those policies. What must be emphasised however is that welfare reforms that are aimed at increasing reciprocity between rights and duties, particularly when those reforms concern policies aimed at obligatory reciprocity, are broadly supported.

\section{$3 \quad$ Explaining welfare state support}

While the above findings provide interesting insight, into welfare state support and support for welfare reforms, it is also important to investigate the reasons that lie behind this support. One of the most frequently used explanations for welfare state support is economic (Gilens 1995; Lip- 
set 1960; Van Oorschot 2002) or primitive (Campbell et al. 1960) selfinterest. This explanation is straightforward and fairly simple. Those in precarious socio-economic positions tend to benefit more from the welfare state than those in strong socio-economic positions. Traditionally, welfare state support is, as Svallfors argues '[o]ne of the most important arenas for contemporary class politics' (Svallfors 1999: 203). Indeed, people in precarious socio-economic positions tend to support economic redistribution, government intervention in the economy, and a strong and substantial welfare state more than those in favourable economic positions (Lipset 1981). Svallfors: '... people who by virtue of their greater assets are the market winners will look upon the market's transactions as more legitimate and be less inclined to redress market's distributions than those who wield less power upon the market' (2007: 189). The fact that those in precarious economic positions have always been the main constituencies of socialist and leftist parties striving for redistribution and economic equality confirms the empirical tenability of this idea (Alford 1967; Nieuwbeerta 1996; Achterberg and Houtman 2009).

It can be expected that these class-related relationships are in decline. Inglehart, for instance, claims that so-called new, ecological or 'quality of life' risks are rising in salience at the cost of the old bread-and-butter type of risks (loss of property, income and jobs). 'According to this diagnosis', Inglehart claims, 'the distributional conflicts over goods that characterized industrial society have given way' (Inglehart 1997: 36). Various authors (Turner 1988; Pakulski and Waters 1996; Hechter 2004) have argued that the concept of 'social class' in its traditional economic sense is hence no longer a valid sociological indicator to describe and explain human behaviour (for them, class is dead). Accordingly, one's position on the labour market and one's economic position supposedly are losing grip on the lives of people in post-industrial society. The idea of 'fluidisation' (Bauman 200o) resonates with this idea. This means that political behaviour, political values and public opinion are thought to be becoming increasingly unpredictable. It is argued that people increasingly formulate their political ideas without taking their own social risks and class position into account (Rose and McAllister 1986). In a similar vein, Pakulski and Waters (1996) write about the rise of 'choice politics' - purely based on individual choice, which is no longer guided by any social factor.

As 'old collective identities of class have been displaced by newer modes of self-identity' (Savage 2001: 79), and people are said to have their own fragmented ideological profiles, this suggests that collective ideals of welfare state support no longer are grounded in a class position and an 
economic egalitarian ideology. In the words of Atkinson: highly individualised people are individuals who 'in their quest for self-realization flit between attitudes, activities and goods like bees in search of pollen' (Atkinson 2007: 362). This would mean that social class no longer determines how people think about economic egalitarian policies and that social class is no longer directly related to opinions about the welfare state.

Moreover, there are other indications that views of the welfare state are decreasingly framed within the context of class conflicts over a fair distribution of social rights. Instead, public opinion toward the welfare state may be increasingly framed in the context of conflicts over a fair distribution of social obligations. Mead argues that: '... social policy must focus on motivation and order rather than opportunity or equality' (Mead 1992: 112). Mead's argument that there is a politics of conduct rather than of class and that the issues of class are no longer at the centre of the political stage (Mead 1992) resonates with the idea that there is a new political culture in which issues of class have given way to new cultural issues about conformity and cultural deviance (Achterberg 2006; Heath et al. 1990). Instead of issues of state intervention, and typical bread and butter issues pertaining to economic redistribution, new issues such as cultural deviancy, crime fighting, and the like have moved centre stage (Rempel and Clark 1997; Clark 1996, 2001; Hechter 2004). A 'culturalisation of politics' may also have affected the public debate about the welfare state.

The willingness to accept cultural diversity is hence a second explanation for welfare state support. In this explanation, support is the result of compassion with the fate of others. This compassion can be fairly broad - including all social categories - or narrow - including only those individuals who the public identifies with, individuals from their own social category. To a certain degree, welfare recipients deviate from the dominant ethos that one has to work in order to provide for oneself. Reciprocal reform can be perceived as a way of adjusting the conduct of welfare recipients in conformity with the dominant work-ethos (Mead 1992). So, we expect to find a correlation between people having authoritarian opinions that emphasise conformity to dominant norms and the support for reciprocal reform.

Our research (see Table 5) indicates that support for the welfare state can still be explained economically. Basic self-interest, for example, appeared to explain support for reciprocal and redistributive reform fairly well. There is a significant relationship between respondents being dependent upon welfare and their support for reciprocal and redistributive reform. This means that people who are dependent on welfare state support tend to be unsupportive of welfare state reforms that infringe upon their economic posi- 
Table 5 Explaining support for reciprocal and distributive reform (OLS regression, method = ENTER; entries are betas)

\begin{tabular}{lcc}
\hline & $\begin{array}{l}\text { Support for reciprocal } \\
\text { reform }\end{array}$ & $\begin{array}{l}\text { Support for distributive } \\
\text { reform }\end{array}$ \\
\hline Income & 0.05 & 0.05 \\
Education & -0.04 & 0.03 \\
Financial insecurity & -0.03 & 0.00 \\
Welfare dependency & $-0.11^{* *}$ & $-0.07^{*}$ \\
Cultural participation & -0.03 & -0.03 \\
Economic egalitarianism & $-0.34^{* *}$ & $-0.22^{* *}$ \\
Authoritarianism & $0.37^{* *}$ & 0.03 \\
R2 & 0.31 & 0.06 \\
$\mathrm{~N}$ & 1706 & 1706 \\
\hline
\end{tabular}

${ }^{*} \mathrm{p}<0.01 ;{ }^{* *} \mathrm{p}<0.001$

Source: Labour, Organization and Social Security data (2006)

tion. Also, having an egalitarian economic outlook still determines support for welfare state reform. The analyses also show, however, that support for reciprocal reform is explained fairly well by one's willingness to accept cultural diversity. Whether one supports more reciprocity in welfare state policies strongly depends on one's views on order and conformism, as the significant correlation between authoritarianism and support for reciprocal reform shows. Support for reciprocal reform is hence both rooted in class interests but also in cultural interests at the same time.

\section{Conclusion}

In this chapter, we investigated people's perceptions about social risks and social solidarity and what this implies for welfare state support and the restructuring of the welfare state. This chapter presents data from a large panel survey executed in the Netherlands in 1995 and 2006, investigating public opinion on social security and the welfare state. What these data show is that the notion of obligatory reciprocity is taking an increasingly central place in the way people think about risks and solidarity. In the words of Mead (1992): the policies of conduct are becoming ever more important and the politics of class are becoming less important in the opinions people have about the welfare state. The centrality of the notion of reciprocity 
does not, however, lead to a rejection of social solidarity. Rather, the willingness to share risks is becoming increasingly dependent upon the type of risk and the 'social character' of welfare benefit recipients. In addition, the idea of reciprocal solidarity does not lead to diminished welfare state support. Rather, and contrary to what is expected based on existing research, reciprocal solidarity translates itself into support for the restructuring of welfare state programmes in the direction of increased reciprocity. Since the restructuring of most welfare programmes in the Netherlands is in the direction of increased obligatory reciprocity, this means that a majority of the Dutch public supports this process of restructuring.

Our general conclusion is that welfare state support has remained high because people support a welfare state which is in transition. People are especially supportive of the welfare state when it conforms to shared ideals of (obligatory) reciprocity, and when the welfare state supports those who are dependent on financial support because of reasons beyond their own control. Moreover, people are more supportive of policies targeted at those who are - in a cultural sense - much like themselves, and less supportive of policies aimed at people who are further away from the cultural mainstream.

This implies that support for increased individual responsibility and less social protection is limited. Support for collectively shared protection against social risks is still present in the Netherlands. But this support varies across risk types and categories of benefit recipients. Social risks perceived to apply to almost everyone - e.g. sickness, ageing - receive the broadest support and support for universal and distributive welfare measures. When more specific social categories are targeted, however, support is more conditional and more characterised by obligatory reciprocity.

\section{Note}

Table 6 Opinions on reciprocity norms in 1995 and 2006 in the Netherlands

\begin{tabular}{lcc}
\hline & 1995 & 2006 \\
& Mean (SD) & Mean (SD) \\
\hline Obligating reciprocity (0-1) & $0.79(0.31)$ & $0.83(0.28)$ \\
Risk reciprocity (0-1) & $0.74(0.33)$ & $0.75(0.34)$ \\
Balanced reciprocity (0-1) & $0.41(0.28)$ & $0.43(0.30)$ \\
Generalised reciprocity (0-1) & $0.89(0.21)$ & $0.80(0.29)$ \\
\hline
\end{tabular}

Source: Tisser solidarity study, Tilburg University, 1995; Arbeid, bedrijf en sociale zekerheid (labour, organisation and social security), SIG/Erasmus University Rotterdam, 2006 


\section{References}

Achterberg, Peter. 2006. Considering Cultural Conflict; Class Politics and Cultural Politics in Western Societies. Maastricht: Shaker Publishers. Achterberg, Peter and Dick Houtman. 2009. "Ideologically 'Illogical'? Why Do the Lower-Educated Dutch Display so Little Value Coherence?" Social Forces 87: 1649-1670.

Achterberg, Peter, Romke van der Veen, and Judith Raven. 2010. Omstreden Solidariteit. Amsterdam: Aksant.

Alford, Robert R. 1967. "Class Voting in the Anglo-American Political Systems." pp. 67-93 in Party Systems and Voter Alignments: Cross-National Perspectives, edited by S.M. Lipset and S. Rokkan. New York: Free Press.

Atkinson, W. 2007. "Beck, individualization and the death of class: a critique." British Journal of Sociology 58(3): 349-366.

Bauman, Z. 20oo. Liquid Modernity. Cambridge: Polity Press.

Becker, J. 2005. "De steun voor de verzorgingsstaat in de publieke opinie, 1970-2002. Een analyse van trends in meningen." Dutch Social and Cultural Planning Agency.

Budge, Ian, Hans-Dieter Klingemann, Andrea Volkens, Judith Bara, and Eric Tanenbaum. 2001. Mapping Policy Preferences: Estimates for Parties, Electors, and Governments 1945-1998. New York: Oxford University Press.

Campbell, Angus, Phillip Converse, E., Warren E. Miller, and Donald E. Stokes. 1960. The American Voter. New York / London / Sydney: John Wiley \& Sons, Inc.

Clark, T.N. 1996. "Structural Realignments in American City Politics: Less Class, More Race, and a New Political Culture." Urban Affairs Review 31(3): 367-403.

Clark, T.N. 2001. "What Have We Learned in a Decade on Class and Party Politics?" in T.N. Clark and S.M. Lipset (eds) The Breakdown of Class Politics: A Debate on Post-Industrial Stratification, 6-39, Westview Press.

De Swaan, A. 1988. In care of the state: health care, education, and welfare in Europe and the USA in the modern era. New York: Oxford University Press.

Gilbert, Neil. 2002. Transformation of the Welfare State. The Silent Surrender of Public Responsibility. Oxford: Oxford University Press.

Gilbert, Neil and Barbara Gilbert. 1989. The Enabling State: Modern Welfare Capitalism in America. New York/ Oxford: Oxford University Press. 
Gilens, Martin. 1995. "Racial Attitudes and Opposition to Welfare." The Journal of Politics 57: 994-1014.

Green-Pedersen, C. 2002. The Politics of Justification. Party Competition and Welfare Retrenchment in Denmark and the Netherlands from 1982 to 1998. Amsterdam: Amsterdam University Press.

Heath, A.F., Jowell, R., Curtice, J and Evans, G. 1990. "The Rise of the New Political Agenda?" European Sociological Review 6(1): 31-48.

Hechter, M. 2004. "From Class to Culture." American Journal of Sociology $110(2): 400-45$.

Hirschman, Albert O. 1980. "The Welfare State in Trouble: Systemic Crisis or Growing Pains?" The American Economic Review 70: 113-116.

Inglehart, R. 1997. Modernization and Postmodernization; Cultural, Economic, and Political Change in 43 Societies. Princeton, New Jersey: Princeton University Press.

Kaase, Max, and Kenneth Newton. 1995. Beliefs in government. Oxford; New York: Oxford University Press.

Lipset, Seymour M. 1960. Political Man: The Social Bases of Politics. Garden City, New York: Doubleday \& Company, Inc.

- 1981. Political Man; Expanded and Updated Edition. Baltimore, MD: John Hopkins University Press.

Mau, Steffen. 2003. The Moral Economy of Welfare States; Britain and Germany Compared. London/New York: Routledge.

Mau, Steffen. 2004. "Welfare Regimes and the Norms of Social Exchange." Current Sociology 52: 53-74.

Mead, Lawrence H. 1992. The New Politics of Poverty: The Nonworking Poor in America. New York: Basic Books.

Murray, Charles A. 1984. Losing ground: American social policy, 1950-1980. New York: Basic Books.

Nieuwbeerta, Paul. 1996. "The Democratic Class Struggle in Postwar Societies: Class Voting in Twenty Countries, 1945-199o." Acta Sociologica 39: 345-383.

Pakulski, J. and M. Waters. 1996. The Death of Class. London, Delhi: Sage. Pierson, Paul. 1994. Dismantling the Welfare State? Reagan, Thatcher, and the Politics of Retrenchment. Cambridge: Cambridge University Press.

Rempel, M. and T.N. Clark 1997. "Post-Industrial Politics: A Framework for Interpreting Citizen Politics Since the 1960s." in M. Rempel and T.N. Clark 9-56 Citizen Politics in Post-Industrial Societies, Boulder: Westview Press.

Ringen, S. 1987. The Possibility of Politics: a Study in the Political Economy of the Welfare State. New York: Oxford University Press. 
Rose, R. and I. McAllister. 1986. Voters Begin to Choose: From Closed Class to Open Elections in Britain. Beverly Hills: Sage.

Savage, M. 2001. "Class Identity in Contemporary Britain: The Demise of Collectivism?" in G. Van Gyes, H. de Witte and P. Pasture (eds) Can Class Still Unite 79-10o Aldershot: Ashgate.

Svallfors, Stefan. 1999. "Political trust and attitudes toward redistribution. A comparison of Sweden and Norway." European Societies 1: 241-268.

- 2007. "Class and Attitudes to Market Inequality: A comparison of Sweden, Britain, Germany and the United States." pp. 189-222 in The Political Sociology of the Welfare State, edited by S. Svallfors. Stanford: Stanford University Press.

Svallfors, S. and Taylor-Gooby, P. (eds.) 1999. The End of the Welfare State? Responses to State Retrenchment. London: Routledge.

Turner, Bryan S. 1988. Status. Milton Keynes: Open University Press.

Turner, Bryan S. 1997. "Citizenship Studies: A General Theory." Citizenship Studies 1: 5-18.

Van der Veen, Romke. 2009. "The Transformation of the Welfare State. What is Left of Public Responsibility?" in Globalization and the State; Sociological Perspectives on the State of the State, edited by W. Schinkel. Palgrave: MacMillan.

Van Oorschot, W. 1999. The Legitimacy of welfare: a sociological analysis of the motives for contributing to welfare schemes. WORC Paper from Tilburg University, no. 17: 1-24

- 2002. "Individual Motives for Contributing to Welfare Benefits in the Netherlands." Policy and Politics 30: 31-46. 



\title{
3 Individualisation: A Double-edged Sword
}

\author{
Does Individualisation Undermine Welfare State Support?
}

\author{
Peter Achterberg and Judith Raven
}

In Chapter two we found that welfare state support is still high in the Netherlands, as it is in many other European welfare states. However, this does not imply that people oppose the changes that have taken place in welfare state policies during the last two decades. On the contrary. We concluded that support for the welfare state in transition is based on an increasingly shared normative ideal of obligatory reciprocity and on perceptions of deservingness. Public opinion about the welfare state and welfare state policies appear to develop in the same direction. In this chapter, we delve deeper into the sociology of welfare state support. The social process of individualisation is often suggested to undermine welfare state support. However, we have not found a decrease in welfare state support. In this chapter we therefore investigate in more detail the claim that individualisation undermines welfare state support. We make a distinction between cultural (or normative) individualisation and (structural) individualisation in social relations. These processes of individualisation appear to have different effects on welfare state support. By making this distinction in different processes of individualisation we are able to explain continued high support for the welfare state. Individualisation not only appears to undermine welfare state support, under certain conditions it can also fuel welfare state support.

\section{Introduction}

In the literature pertaining to the legitimacy of the welfare state, it is often implied that there is, or should be, a crisis of the welfare state for many different reasons. One of the reasons most often mentioned is the process of individualisation (e.g. Giddens 1994; Inglehart 1997; Trommel and Van 
der Veen 1999). Yet, while most authors use the same term, the conceptualisation of individualisation differs widely, and with that the reasons for it causing an alleged decline in welfare state legitimacy. While the number of interpretations and conceptualisations of individualisation may be numerous, most explanations boil down to two central ideas of cultural and structural individualisation (e.g. Atkinson 2007: 353).

Cultural individualisation implies growing ideals of individual liberty and freedom. A great number of studies have shown that in the Netherlands, similar to the rest of the Western world, people increasingly emphasise ideals of individual freedom, self-actualisation and individual level political participation (e.g. Inglehart 1977, 1997; Duyvendak 2004), and that the importance of socially collectivist values is diminishing (Flanagan and Lee 2003; Houtman 2003; Inglehart 1997). Cultural individualisation is said to undermine welfare state support for two reasons. First, and the most straightforward reason, is that as the importance of collectivism declines and as more and more people emphasise individual freedom, collectively organised institutions such as the welfare state come under pressure. From this perspective, a system of collectively shared risks is becoming obsolete.

The second reason is based on the suggestion that materialists deeply value the welfare state, whereas postmaterialists are not concerned for materialist issues, and hence do not care as much about the welfare state (Inglehart 1997; see also Van Oorschot 2000: 39). This suggestion is based on evidence that when values shift towards individualism, as measured using Inglehart's postmaterialism index, this goes together with a decline in materialism. In Inglehart's index, cultural individualists are viewed as postmaterialists and cultural collectivists as materialists. Hence, whether cultural individualisation is measured and seen as a decrease in cultural collectivism or of materialism, the suggestion is made that this form of individualisation seriously undermines support for the welfare state.

The second concept of individualisation entails a more structuralist, or better yet, poststructuralist approach. This approach is concerned with the way in which social structures, which surround individuals, give guidance to individual lives. It is argued that individualisation means individuals are less embedded in social structures such as class, religion and traditions. Beck and Beck-Gernsheim argue that in modern, individualised societies, individuals are increasingly faced with decisions about their own life course; the 'standard biography' has been replaced by a 'do-it-yourself biography' (Beck and Beck-Gernsheim 2002). As a result, structurally individualised people are no longer members of trade unions 
and churches, and are no longer integrated into the traditional political system. The ultimate consequence is that what people experience, what risks they run, and the position they take up in society are no longer institutionally pre-determined. Rather, these become highly individualised and may differ from individual to individual, from situation to situation (Beck 1997, see also Leisering and Leibfried 1999).

According to this line of thought, the disembedding of individuals out of once influential institutions such as class, religion and politics has swept away traditional collective grounds underlying political and socioeconomic values. As a consequence, people are bound to make their own strictly individual and highly volatile choices and have their own opinions, even about the welfare state (Beck 1992; Beck and Beck-Gernsheim 2002). As a result, individualisation theorist Beck (1997: 144) argues, interests, opinions and issues of conflict become increasingly fragmented. 'Society can no longer look in the mirror and see social classes. The mirror has been smashed and all we have left are the individualized fragments' (Beck and Willms 2004: 107).

Whereas the welfare state was built by certain interest groups having enough political power and resources to build a welfare state (Korpi 1983) and maintain it (Brooks and Manza 2007), it is evident that the increased fragmentation of risks, interests and opinions will ultimately lead to a crisis in welfare state legitimacy. The ultimate consequence is that people in lower socio-economic positions, who run a high chance of encountering socio-economic risks, no longer translate these risks into pro-welfare state opinions.

While both ideas of cultural and structural individualisation are often brought together under the term individualisation, and both processes can be seen to contribute to a crisis of welfare state legitimacy, they are seldom related to one another (see for an exception Pakulski and Waters 1996), especially in empirical research (Elchardus 2008). As Beck notes, 'Individualization can no longer be understood as a mere subjective reality which has to be confronted with objective class analysis. Because individualisation not only affects the Überbau - ideology, false consciousness - but also the economic Unterbau of "real classes".. [it] is becoming the social structure of ... society itself' (Beck and Beck Gernsheim 2002: xxii). In this chapter, we will investigate whether cultural and structural individualists are more negative towards the welfare state than collectivists and whether it is true, for cultural and structural individualists, that the presence of socio-economic risks no longer translates into support for the welfare state. 
In the remainder of this chapter, we will discuss the current state of research on welfare state support and individualisation and put forward some hypotheses. These will then be tested in the section that follows. At the end of the chapter, we will discus the theoretical relevance of our findings and relate this discussion to the three central questions to be answered in this volume.

\section{Individualisation, socio-economic risks and solidarity}

2.1 Structural and cultural individualisation and support for the welfare state

A central idea in Beck's (1992; Beck and Beck Gernsheim 2002) Risk Society is that risks are radically individualised and are no longer concentrated among the unhappy few. Risks have thus become more pervasive throughout society, are decreasingly detached from class position and cannot be contained by traditional, collective and highly standardised means such as the welfare state. If this is the case, we expect that structural individualists do not appreciate the welfare state very much. In contrast, individuals still highly embedded in social institutions should be proponents of the welfare state. Several studies have determined that a process of structural individualisation is taking place in the Netherlands, most notably indicated by processes of depillarisation (Middendorp 1991), secularisation (Achterberg et al. 2009) and declining union membership (Visser 2006). Whether or not this ongoing structural individualisation really leads to declining welfare state support remains an empirical question.

In addition, several studies focused on the cultural changes taking place within Western societies have abundantly shown that there most definitely is a shift towards increased cultural individualism (Inglehart 1997; Inglehart and Norris 2003; Inglehart and Welzel 2005). As explained above, it can be expected that this noted rise in cultural individualisation has gone hand-in-hand with decreased levels of support for the welfare state. In a study of 43 countries, Inglehart (1997) shows that in countries where individual freedom is high on the political agenda, support for welfare state intervention and expansion is much lower than in other countries. However, it is not possible to conclude that the rise of cultural individualism goes hand-in-hand with decreased levels of welfare legitimacy based on this macro-level evidence. Let us explain.

First, Inglehart himself shows that people who can be classified as postmaterialists, who greatly value individual freedom, are more inclined to vote for traditionally leftist parties such as socialist or social democratic parties 
(Inglehart 1977; 1997, see also Achterberg and Houtman 2006). These parties have traditionally been important players in the rise and maintenance of welfare states. That these cultural individualists have a favourable tendency towards parties generally seen to be in favour of the welfare state places the alleged anti-welfarism of these individualists in question.

Secondly, a study by Erickson and Laycock (2002) among the members of the Canadian Social Democrats shows that a preference for socialism and policies focused on decommodification is much more prevalent among individualists. Those scoring lower on a scale measuring individualism are generally less supportive of decommodifying policies, policies associated with a strong welfare state. The mere fact that individualism exists among members of a social democratic party underscores that individualism probably does not necessarily lead to a decrease in support for the welfare state. What's more, the fact that individualism leads to more support for the welfare state, even among these social democrats, implies that it is not self-evident that cultural individualism should lead to a decrease in support for the welfare state.

Third, a recent study by Achterberg, Van der Veen and Raven (2010) shows Dutch cultural individualists are more supportive of a generous welfare state and less supportive of welfare state reforms than cultural collectivists. They argue, following Houtman, Achterberg and Derks (2008), that welfare beneficiaries are increasingly seen as people with more or less 'deviant' lifestyles - being dependent upon welfare whereas the majority of the public is not. Cultural individualists who are more tolerant of deviant lifestyles tend to be more lenient towards welfare beneficiaries and to the welfare state in general, whereas cultural collectivists, emphasising conformity and order, are not. In other words, the authors find the exact opposite from what is expected, which gives rise to the expectation that cultural individualists are, in fact, more tolerant of the welfare state. In sum, whether or not cultural individualism leads to a decline in welfare state legitimacy remains an empirical question, one that will be answered in this chapter.

\subsection{Individualisation, the death of class, and welfare state support}

Although Inglehart's work is more focused on describing cultural changes, he, like Beck, suggests that the risks of life become incalculable through the process of modernisation - and that ironically enough, the focus on social risks has risen dramatically (Inglehart 1997: 36). Yet, like Beck, he claims that this growing concern for risks mainly concerns so-called new, ecological or quality of life risks, and not the old, bread-and-butter type of risks (loss of 
property, income and jobs). 'According to this diagnosis', Inglehart claims, 'the distributional conflicts over goods that characterized industrial society have given way' (Inglehart 1997: 36). This development would suggest that there are two marked expectations for highly (structural and/ or cultural) individualised people. The first is that these individuals no longer have clearly defined values about their socio-economic fates, also termed fluidisation (Bauman 200o). The second is that highly individualised socio-economic risks no longer automatically translate into welfare state support. We elaborate on both expectations below.

First, the idea of fluidisation resonates in the writings of influential theorists of political behaviour as well. According to these theorists, political behaviour, political values and public opinion have become increasingly unpredictable. They argue that people increasingly formulate their political ideas without taking their own social risks and class position into account (Rose and McAllister 1986). In a similar vein, Pakulski and Waters (1996) write about the rise of 'choice politics' - purely based on individual choice, and no longer guided by any social factor. In this sense, Western publics are said to have become 'fluid', 'wobbling' or 'adrift' (Andeweg 1982). 'Old collective identities of class have been displaced by newer modes of self-identity' (Savage 2001: 79), and individualised people supposedly have their own fragmented ideological profiles, suggesting that collective ideals of welfare state support no longer occupy a clearly defined, ideological dimension for those who are most (structurally and or culturally) individualised. In the words of Atkinson, highly individualised people are individuals who: 'in their quest for self-realization flit between attitudes, activities and goods like bees in search of pollen' (Atkinson 2007: 362).

The second expectation for highly individualised people is that the socio-economic risks they (temporarily) encounter no longer translate themselves into clearly defined positions about welfare state protection. Various authors (Turner 1988; Pakulski and Waters 1996; Hechter 2004) have argued that the concept of 'social class', in its traditional economic sense, is no longer a valid sociological indicator to describe and explain human behaviour; for them, class is dead. According to these authors, individual socio-economic positions are no longer the primary determinants of individual behaviour in post-industrial societies. While this thought continues to resonate in the writings of several contemporary sociologists, surprisingly little effort has been undertaken to empirically investigate whether social class is no longer an important factor in the organisation and structuring of individual political views. 
While several authors claim 'class is dead', many others continue to explain welfare state support as stemming from 'economic' (Gilens 1995; Lipset 1960; Van Oorschot 2002) or 'primitive' (Campbell, Converse, Miller, and Stokes 1960) self-interest. This explanation is straightforward and fairly simple. Those in precarious socio-economic positions or those experiencing the greatest risk of becoming unemployed, impoverished and so on, tend to benefit more from redistributive welfare state policies than those in stronger socio-economic positions. Traditionally, support for the welfare state is, as Svallfors (1999: 203) argues, '[o]ne of the most important arenas for contemporary class politics.' Indeed, people in precarious socio-economic positions tend to support economic redistribution, government intervention in the economy and a strong and substantial welfare state more than those in favourable economic positions (Lipset 1981). 'People who by virtue of their greater assets are the market winners will look upon the market's transactions as more legitimate and be less inclined to redress market's distributions than those who wield less power upon the market' (Svallfors 2007: 189). The fact that those in precarious economic positions always have been the main constituencies of socialist and leftist parties confirms the empirical tenability of this idea (Alford 1967; Nieuwbeerta 1996). Individuals in precarious socio-economic positions and those confronting socio-economic risks tend to vote for leftist parties in order to redistribute scarce and valuable resources from the haves to themselves, the have-nots, in order to achieve more economic equality (Achterberg and Houtman 2009; Achterberg 2006). In short, the strength of one's economic position is therefore directly related to one's ideological values about economic (in)equality, redistribution and welfare state support (Middendorp 1991; Svallfors 1991). The weaker people's economic positions, the more they tend to adhere to an egalitarian ideology (De Witte 1997; Marshall et al. 1988; Svallfors 1991; Wright 1985). For those in stronger economic positions, the reverse is true - they support laissezfaire values and they support market liberalism rather than a strong and expensive welfare state.

It is questionable whether the process of individualisation has caused a decline in the relationship between socio-economic status and welfare state support. For instance, Svallfors (1999) has shown that class differences in welfare state support have not declined at all - a research finding recently replicated by Achterberg and De Koster (2009). Moreover, in systematic empirical research, Elchardus (2007) and De Beer (2004; see also De Beer and Koster 2009) have shown that the influence of socioeconomic background on welfare opinions has increased - a remarkable 
finding given the context of ongoing cultural and structural individualisation. Therefore, the relationship between individualised people, the socio-economic risks they face and support for the welfare state remains an empirical question, one which we address below.

\subsection{Hypotheses}

Various scholars have linked the process of individualisation to a decline in welfare state legitimacy. Above, we distinguished two types of individualisation - cultural and structural - the former indicating a growing emphasis on individual freedom, the latter indicating a growing detachment of individuals from their institutional environment. Following Inglehart we should expect to find that culturally individualised people do not support the welfare state (hypothesis 1). Following Beck, we should expect that the same holds true for structurally individualised people (hypothesis 2). Both Inglehart and Beck claim that preferences about political issues are increasingly becoming individualised traits. If this is true, then we should expect that welfare values are no longer clearly defined along a single ideological dimension for highly (culturally and structurally) individualised people (hypothesis 3). Finally, following the arguments about the death of class, we expect that socio-economic risks associated to social class no longer translate themselves into support for the welfare state for (cultural and structural) individualists (hypothesis 4). We will test these hypotheses below using recent data for the Netherlands, one of the most highly individualised countries in the world (Inglehart 1997).

\section{Data and measures}

In order to test the hypotheses proposed above, we used data collected in 2006 in the Netherlands. These data stem from a representative data panel collected by the Centerdata research bureau. A total of 2,682 individuals were selected to participate in the study and 1,972 respondents completed the questionnaire, providing a response rate of 73 per cent. A comparison with official statistics from Statistics Netherlands (Centraal Bureau voor de Statistiek) showed that older people, higher income groups, and higher educational groups were overrepresented in the sample, which we corrected using a weighting factor.

Cultural individualisation was measured by using items representing postmaterialism. Respondents were asked to indicate which was the 
most important problem facing our country today: fighting rising prices, maintaining order in the nation, protecting free speech or giving people a greater say in important political decisions. Next, respondents were asked to indicate what the second greatest problem was facing our country. Using this information we constructed four variables indicating the relative importance of the four issues at hand; those not choosing an issue were assigned a score of one, those choosing an issue as the second problem were assigned a score of two, those immediately choosing an issue as their first choice were assigned a score of three. A factor analysis on these four items revealed that the individualist items (free speech and a greater say in national matters) clustered together, as did the collectivist issues (fighting rising prices and maintaining order). These scales were combined to create a final scale measuring cultural individualism, whereby higher scores indicate a greater degree of cultural individualism.

As discussed above we chose to measure structural individualisation as the disembeddedness of three central institutions: religion, class and politics. Religious disembeddedness was measured by asking whether the respondent is a member of a religious denomination $(1=$ no, $\mathrm{o}=$ yes $)$. Class disembeddedness was measured by asking whether the respondent has much confidence in trade unions $(1=$ no, $o=$ yes $)$. Finally, political disembeddedness was measured by asking whether the respondent intends to vote in the next election $(1=$ no, $o=y e s)$. Factor analysis on these three indicators revealed one scale measuring structural individualisation could be constructed - higher scores on this scale stand for a greater degree of structural individualism.

Support for the welfare state was measured using three subscales. The first subscale taps into respondents' values pertaining to privatisation of social insurances. Using a five-point scale, respondents were asked five questions about their thoughts on whether social insurance against 1) unemployment; 2) occupational disability; 3) ageing; 4) the loss of a spouse or partner; and 5) illness should be a government responsibility (1) or an individual responsibility (5). Factor analysis on these five items showed that a scale measuring a preference for privatisation could be constructed, whereby higher scores on this scale stand for support for privatisation. The second subscale concerns opinions about deservingness and is constructed using 31 items asking respondents whether they think a certain social category, such as mothers on social assistance, poor people, or foreigners, are entitled to welfare support. Again, factor analysis showed that a scale for the degree to which respondents classify these social categories as deserving could be constructed, whereby higher scores on this 
scale stand for a greater degree of deservingness. Lastly, the third subscale measures support for social security. We did this using six items, on a scale from 1 (completely disagree) to 5 (completely agree). These items included: 1) I would gladly take care of my own social insurance; 2) I don't want changes in social security to cost me anything; 3) individuals with a low income profit the most from the social security system; 4) receiving social benefits is something to be ashamed about; 5) if you look at it carefully, you'll see that everybody profits from the social security system; and 6) I would gladly pay more than I do right now for a sufficient social security system. ${ }^{1}$ Again, factor analysis showed that a scale 'support for social security' could be constructed.

Figure 1 shows the distributions of the three subscales used to measure welfare state support.

Figure 1 Distributions of the three subscales used to measure welfare state support
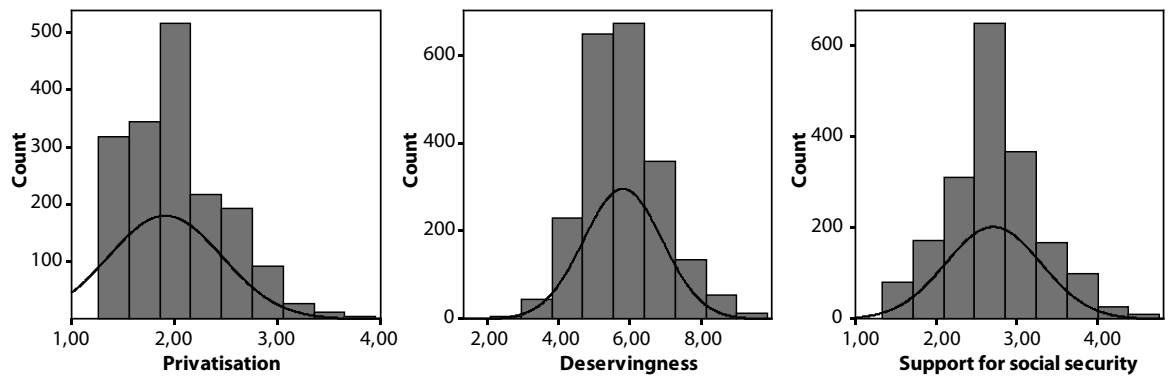

In Table 1, we report on the secondary factor analysis of the three subscales. Higher scores (positive or negative) for the factor loadings represent a clearer representation of each subscale in the latent ideological dimension of welfare state support. From Table 1, we see that it is possible to create a comprehensive scale measuring welfare state support - higher scores on this scale represent more positive views about the welfare state.

We used five indicators to measure socio-economic insecurity. Education was measured using a discrete variable equalling the respondent's number of years of schooling. Second, we measured unemployment by asking whether a respondent was unemployed at that moment $(1=$ not unemployed, $2=$ partially unemployed ${ }^{2} 3=$ totally unemployed). Third, we measured household income using four categories of self-reported, net monthly income: 1) 1,150 Euros or less; 2) 1,151 to 1,800 Euros; 3 ) 


\begin{tabular}{lc}
\hline & Factor loadings \\
\hline Privatisation & -.78 \\
Social security support & .68 \\
Deservingness & .76 \\
\hline Eigenvalue & 1.65 \\
R2 & .54 \\
$\mathrm{~N}$ & 1639 \\
\hline
\end{tabular}

1,801 to 2,600 Euros; and 4) 2,601 Euros or more. Fourth, to measure the risk of unemployment we asked respondents to indicate what they thought the chances were that they would lose their job within the next twelve months $(1=$ no chance at all, through $5=$ very high chance). Finally, to measure welfare dependency, we asked respondents a series of eight questions about whether they were dependent on social assistance, unemployment benefits, occupational disability benefits, old-age pensions, and so on (o = no, $1=$ yes). The answers to these questions were summed up to give an indication of the degree to which the respondent is dependent on welfare.

\section{$4 \quad$ Results}

We started our analyses by investigating the degree to which cultural and structural individualism are related to welfare state support.

Table 2 Individualism and welfare state support

\begin{tabular}{lll}
\hline & Welfare state support & $N$ \\
\hline Cultural individualism & $.21^{* *}$ & 1639 \\
Structural individualism & $-.15^{* *}$ & 1509 \\
\hline${ }^{*} \mathrm{p}<0.05 ;{ }^{* *} \mathrm{p}<0.01$ & &
\end{tabular}

Two conclusions can be drawn from these first results. First, cultural individualism does not lead to lower welfare state support, causing us to reject our first hypothesis. Rather, the results show that culturally individualised people do support the welfare state. However, this finding 
does not mean that all sorts of individualisation lead to more support for the welfare state. Following Beck, we expected to find low levels of support among structurally individualised people and this hypothesis is confirmed, although it must be noted that in comparison to the strong effect of cultural individualism, the effect of structural individualism is lower. In sum, given that both types of individualism render radically different effects on welfare state support, we cannot unequivocally say that individualism is related to lower welfare state support - structural individualism is whereas cultural individualism is not. This means that individuals who 'feel' like free individuals are more supportive, whereas individuals who 'are' freer are less supportive.

Next, the fluidisation hypothesis suggests that political ideological values pertaining to the 'good old' welfare state are no longer grounded in a solid, collective, value system. Here we aim to test this idea by determining whether welfare state ideology is highly scattered among cultural individualists. Below, in Table 3, we present the results of the factor analysis shown in Table 1, but now calculated for three different groups: those who have a low score on the cultural individualisation scale, those with an intermediate score and those with a high score. Following our third hypothesis, we should expect to find a less coherently ordered value pattern for highly individualised individuals, which should amount in lower factor loadings and lower eigenvalues (indicating less structure). In fact, following our hypothesis, we should expect to find that no clear cut ideological dimension is underlying responses to the three subscales for highly individualised respondents - amounting in factor loadings close to zero and an eigenvalue close to one.

Table 3 The association between the four support scales for three categories of cultural individualists

\begin{tabular}{lccc}
\hline & Low Cl & Medium Cl & High Cl \\
\hline Privatisation & -.79 & -.79 & -.76 \\
Social security support & .62 & .67 & .73 \\
Deservingness & .75 & .74 & .78 \\
\hline Eigenvalue & 1.56 & 1.62 & 1.72 \\
R2 & .52 & .54 & .57 \\
$\mathrm{~N}$ & 646 & 532 & 460 \\
\hline
\end{tabular}


Although we expected to find no clear value pattern among individualists (those scoring high on cultural individualism), we found the exact opposite. When collectivists (those with a low score on the cultural individualism scale) are compared to individualists, we find a more coherently defined ideological outlook on welfare rather than a lack of coherency, which refutes our expectation. In Table 4, we present the results of the same analysis for structural collectivists and structural individualists.

Table 4 The association between the four support scales for three categories of structural individualists

\begin{tabular}{lccc}
\hline & Low SI & Medium SI & High SI \\
\hline Privatisation & -.78 & -.79 & -.78 \\
Social security support & .67 & .73 & .70 \\
Deservingness & .76 & .73 & .76 \\
\hline Eigenvalue & 1.63 & 1.69 & 1.69 \\
R2 & .54 & .56 & .56 \\
$\mathrm{~N}$ & 795 & 413 & 300 \\
\hline
\end{tabular}

Again, there is no evidence of a decreased ideological conflict about welfare within the category of structural individualists, unequivocally refuting our third hypothesis. Rather, Tables 3 and 4 both demonstrate that conflict about welfare state support is most profound among highly individualised respondents. In other words, values pertaining to the welfare state are coherently organised among individualised respondents but not as much among collectivist ones.

Next, we want to know whether and how these welfare values are linked to the socio-economic risks people encounter. In Table 5, we show the results of a linear regression analysis differentiated into three categories based on the degree of cultural individualisation. The basic hypothesis is that, for individualists, there is no marked influence of these socioeconomic risks (class risks) on the way people think about the welfare state. The last column indicates whether the effects between the groups are getting stronger $(++=$ moving away from zero) or weaker $(--=$ moving towards zero) with ongoing individualisation.

Looking at the results in Table 5, we can draw the conclusion that there is hardly any relationship between social risks encountered by collectivists who are low on cultural individualism and their opinions about the 
Table 5 Cultural individualisation, socio-economic risks and solidarity (OLS regression, betas shown, Method is enter, pairwise deletion)

\begin{tabular}{lccll}
\hline Cultural individualisation & Low Cl & Medium Cl & High Cl & $\begin{array}{l}\text { Effect increase(+)/ } \\
\text { decrease (-) }\end{array}$ \\
\hline Education & -.04 & $-.06^{*}$ & $-.10^{* *}$ & ++ \\
Income & $-.09^{*}$ & $-.07^{*}$ & $-.09^{*}$ & $+/-$ \\
Risk of unemployment & $.09^{*}$ & .01 & .02 & -- \\
Unemployment & .06 & $.09^{*}$ & $.15^{* *}$ & ++ \\
Welfare dependency & .00 & $.18^{* *}$ & $.15^{* *}$ & + \\
R2 & .02 & .04 & .07 & ++ \\
$\mathrm{N}$ & 646 & 530 & 460 & \\
\hline
\end{tabular}

welfare state. Only people with low incomes and people with a high risk of unemployment are supportive of the welfare state. Moreover, most of the effects found for these structural variables tend to become stronger as cultural individualism increases, causing us to reject our last hypothesis. The best explanatory model is found for cultural individualists - when cultural individualists gave lower levels of education, income, people who are unemployed or dependent on welfare, they are more supportive of the welfare state. Based on these findings we can conclude that cultural individualism does not cause the expected results, rather, those experiencing social risks favour the welfare state more than more socio-economically secure individuals.

However, we can confirm our hypothesis in terms of structural individualists. In this case, little effect is found when looking at social background. Remarkably enough, we find that more highly educated struc-

Table 6 Structural individualisation, socio-economic risks and solidarity (OLS regression, betas shown, Method is enter, pairwise deletion)

\begin{tabular}{lcccl}
\hline Structural individualisation & Low Cl & Medium Cl & High Cl & $\begin{array}{l}\text { Effect increase(+)/ } \\
\text { decrease (-) }\end{array}$ \\
\hline Education & -.04 & -.02 & $.09^{*}$ & + \\
Income & -.02 & .03 & -.05 & $+/-$ \\
Risk of unemployment & $.08^{*}$ & .00 & .04 & - \\
Unemployment & $.07^{*}$ & -.04 & -.06 & - \\
Welfare dependency & $.17^{* *}$ & $.08^{*}$ & $.08^{*}$ & - \\
R2 & .05 & .01 & .02 & - \\
\hline $\mathrm{N}$ & 793 & 413 & 300 & \\
\hline
\end{tabular}


tural individualists are more supportive of the welfare state - a striking contradiction to the main class paradigm that those experiencing more social risks will be more supportive of the welfare state. Moreover, we find the strongest relationship between social background and support for the welfare state for collectivists. As expected, those with a greater risk of unemployment, the unemployed and those dependent on welfare are more supportive of the welfare state.

In short, our fourth hypothesis is rejected in relation to cultural individualism but is confirmed in relation to structural individualism. In regards to cultural individualism, we find that socio-economic insecurities and social risks play an important role for welfare state support. In contrast, these risks are unimportant in explaining welfare state support among structural individualists.

\section{Summary and conclusions}

As the literature discussed in this chapter suggests, the process of individualisation has often been linked to a decline in welfare state legitimacy. It is commonly argued that individualisation causes a decline in people's appreciation of a collectively organised welfare state. In this chapter, we studied whether individualists really support the welfare state less than collectivists. Distinguishing between two types of individualism, we found that people who are structurally disembedded from their institutional environment - the structural individualists - indeed are less supportive of the welfare state, giving credence to the aforementioned suggestions of declining welfare legitimacy. Moreover, the socio-economic risks encountered by structural individualists, which are tied to their actual class position, do not translate into welfare state support. Put differently, structural individualists do not support the welfare state irrespective of their socio-economic interests. Resonating with findings in the current 'death of class' debate - in which class is proclaimed dead or a 'zombie category' at best (Beck and Beck-Gernsheim 2002: 203-4; Beck 2002: 47) - the class position of structural individualists does not lead them to support the welfare state, even though some of them encounter more socio-economic risks than others.

Remarkably enough, we find that people who can be classified as cultural individualists - those who emphasise individuality - are more supportive of the welfare state than those who do not emphasise individuality. Moreover, we find that socio-economic position and interests are 
more important for the way in which cultural individualists think about the welfare state. Hence, cultural individualists are more supportive of the welfare state, in particular because their weak economic position gives rise to support for more economically protective and redistributive policies.

Whereas these findings clearly contradict pessimistic accounts concerning individualism and welfare state legitimacy, they also beg for an alternative explanation as to why these cultural individualists support the welfare state. An obvious explanation might be that since cultural individualists emphasise their individuality, they may have come to think that they are socio-economically vulnerable because they are not protected collectively. To compensate for their increased sense of vulnerability, and stemming from their own self-interest, these individualists are more supportive of a collective, protective system of social security (cf. Dekker 2008; Giddens 1998, Castells 1996). In the next chapter on the flexibilisation of the labour market we will go deeper into this explanation. Future research could elaborate on this aspect further, in an attempt to determine whether cultural individualists reflect differently on socio-economic insecurity than collectivists do.

Returning to the research questions addressed in the introduction of this volume: in this chapter we have focused on the willingness to share social risks. We have shown that traditional class solidarity, which was previously the foundation of the welfare state, has apparently dissolved to some extent, as it does not influence welfare state support for structural individualists. However, it does influence welfare state support for cultural individualists. In other words, in individualised societies, part of the public (cultural individualists) still supports the welfare state because of its insurance of class-related risks, while another part of society (structural individualists) does not. Our results endorse the hypothesis of diminishing support for the welfare state because structural individualism causes a decrease in the willingness to share risks collectively. However, our results also contradict this hypothesis because cultural individualism causes an increase in the willingness to share risks collectively. With regard to the perception and management of risks, we have shown that citizens' support for state responsibility for social risks has become less coherent due to the process of individualisation (see also Achterberg and Houtman 2009). Some scholars argue that welfare state retrenchment is seldom successful because politicians fear electoral punishment for unpopular reforms (Pierson 1994, 1996, 2001; Brooks and Manza 2006). Our results, however, imply that politicians do not need to fear electoral punishment as a result of decreasing support for welfare arrangements 
due to the process of individualisation. As we have shown, one form of individualisation leads to a decrease in support whereas the other form of individualisation leads to an increase in support. Nonetheless, due to the declining coherence of public opinion, 'pleasing' the individualised public in order to generate electoral gain has become increasingly difficult.

Hence, individualisation is a double-edged sword. On the one hand, structural individualisation is causing a breakdown of welfare legitimacy and a weakening of the more or less automatic translation of social risks into welfare state support. On the other hand, cultural individualisation is having the reverse effect - it is causing an increase in welfare legitimacy and a more definitive translation of social risks into support for the welfare state. While both processes of individualisation are occurring simultaneously, and more or less cancel each other out, no grand changes in welfare state legitimacy can be expected as a result of individualisation.

\section{Notes}

1 Some items in this subscale were recoded to match the direction of the majority of the items.

2 In the Netherlands, it is possible to be partially unemployed.

\section{References}

Achterberg, Peter and Willem de Koster. 2009. submitted. "An Unstable Electorate or a New Cultural Cleavage? Class Politics and Cultural Politics in Great Britain and the Netherlands."

Achterberg, Peter and Dick Houtman. 2006. "Why Do So Many People Vote 'Unnaturally'? A Cultural Explanation for Voting Behavior." European Journal of Political Research 45(1): 75-92.

- 2009. "Ideologically "Illogical"? Why Do the Lower-Educated Dutch Display so Little Value Coherence?" Social Forces 87(3): 1649-1670.

Achterberg, Peter, Dick Houtman, Stef Aupers, Willem de Koster, Peter Mascini, and Jeroen van der Waal. 2009. "A Christian Cancellation of the Secularist Truce? Waning Christian Religiosity and Waxing Religious Deprivatization in the West." Journal for the Scientific Study of Religion.

Achterberg, Peter, Romke van der Veen, and Judith Raven. 2009, submitted. "The ideological roots of welfare state reform; Support for distributive and reciprocal reform in the Netherlands."

Alford, Robert R. 1967. "Class Voting in the Anglo-American Political Sys- 
tems." Pp. 67-93 in Party Systems and Voter Alignments: Cross-National Perspectives, edited by S.M. Lipset and S. Rokkan. New York: Free Press. Andeweg, Rudy B. 1982. Dutch Voters Adrift; On Explanations of Electoral Change. Leiden, the Netherlands: Leiden University.

Atkinson, Will. 2007. "Beck, individualization and the death of class: a critique." British Journal of Sociology 58(3): 349-366.

Beck, Ulrich. 1992. "From Industrial Society to the Risk Society: Questions of Survival, Social Structure and Ecological Enlightenment." Theory, Culture and Society 9: 97-123.

- 1997. The Reinvention of Politics: Rethinking Modernity in the Global Social Order. Cambridge, UK: Polity.

- 2002. "The Cosmopolitan Society and its Enemies." Theory, Culture and Society 19(1-2): 17-44.

Beck, Ulrich, and Elisabeth Beck-Gernsheim. 2002. Individualization: Institutionalized Individualism and its Social and Political Consequences. London, UK: Sage.

Beck, Ulrich, and Jerry Willms. 2004. Conversations with Ulrich Beck. Cambridge, UK: Polity Press.

Brooks, Clem, and Jeff Manza. 2007. Why Welfare States Persist; The Importance of Public Opinion in Democracies. Chicago: The University of Chicago Press.

Campbell, Angus, Philip Converse, Warren Miller, and Donald Stokes. 1960. The American Voter. New York/London/Sydney: John Wiley and Sons, Inc.

Castells, Manuel. 1996. The Rise of the Network Society. Oxford, UK: Blackwell Publishers.

De Beer, Paul. 2004. "Individualisering zit tussen de oren." Pp. 18-38 in Kiezen voor de kudde; Lichte gemeenschappen en de nieuwe meerderheid edited by J. W. Duyvendak and M. Hurenkamp. Amsterdam, the Netherlands: Van Gennep.

De Beer, Paul, and Ferry Koster. 2009. Sticking together or falling apart? Solidarity in an era of individualization and globalization. Amsterdam, the Netherlands: Amsterdam University Press.

De Witte, Hans. 1997. "De ideologische cultuur van arbeiders in Vlaanderen. Een replicatie en uitbreiding op basis van de IPSO-data." Tijdschrift voor Sociologie 18(1-2): 53-78.

Dekker, Fabian. 2008. "Flexibele arbeid, werkonzekerheid en gemeenschapsgevoel. Steun voor collectieve sociale zekerheid in een flexibel arbeidsbestel." Sociologie 4(1): 38-52.

Duyvendak, Jan Willem. 2004. Een eensgezinde, vooruitstrevende natie. 
Over de mythe van dé individualisering en de toekomst van de sociologie. Amsterdam: Vossiuspers University of Amsterdam.

Erickson, Lynda and David Laycock. 2002. "Post-Materialism versus the Welfare State?" Party Politics 8(3): 301-325.

Flanagan, Scott C., and Aie-Rie Lee. 2003. "The New Politics, Culture Wars, and the Authoritarian-Libertarian Value Change in Advanced Industrial Democracies." Comparative Political Studies 36(3): 235-270. Giddens, Anthony. 1994. Beyond Left and Right. Cambridge, UK: Polity Press.

Giddens, Anthony. 1998. The Third Way. Cambridge, UK: Polity Press.

Gilens, Martin. 1995. "Racial Attitudes and Opposition to Welfare." The Journal of Politics 57(4): 994-1014.

Hechter, M. 2004. "From Class to Culture". American Journal of Sociology $110(2): 400-445$.

Houtman, Dick. 2003. Class and Politics in Contemporary Social Science, Marxism Lite and Its Blind Spot for Culture. Hawthorne NY: Aldine de Gruyter.

Houtman, Dick, Peter Achterberg, and Anton Derks. 2008. Farewell to the Leftist Working Class. New Brunswick, NJ: Transaction.

Inglehart, Ronald. 1977. The Silent Revolution: Changing Values and Political Styles among Western Publics. Princeton, NJ: Princeton University Press.

Inglehart, Ronald. 1997. Modernization and Postmodernization; Cultural, Economic, and Political Change in 43 Societies. Princeton, NJ: Princeton University Press.

Inglehart, Ronald and Peter Norris. 2003. Rising Tide; Gender Equality and Cultural Change Around the World. Cambridge, UK: Cambridge University Press.

Inglehart, Ronald and Christian Welzel. 2005. Modernization, Cultural Change, and Democracy: The Human Development Sequence. New York: Cambridge University Press.

Korpi, Walter. 1983. The Democratic Class Struggle. London, UK: Routledge and Kegan Paul.

Leisering, Lutz and Stephan Leibfried. 1999. Time and Poverty in the Welfare State. Cambridge, UK: Cambridge University Press.

Lipset, Seymour M. ed. 1960. Political Man: The Social Bases of Politics. Anchor Books edition. Garden City, NY: Doubleday and Company, Inc. Lipset, Seymour M. 1981. Political Man; Expanded and Updated Edition. Baltimore, MD: John Hopkins University Press.

Marshall, Gordon, Howard Newby, David Rose, and Carol Vogler. 1988. 
Social Class in Modern Britain. London, UK: Hutchinson.

Middendorp, Cees. P. 1991. Ideology in Dutch Politics; The democratic system reconsidered 1970-1985. Assen/Maastricht, the Netherlands: Van Gorcum.

Nieuwbeerta, Paul. 1996. "The Democratic Class Struggle in Postwar Societies: Class Voting in Twenty Countries, 1945-199o." Acta Sociologica 39(4): 345-383.

Pakulski, Jan and Malcolm Waters. 1996. "The Reshaping and Dissolution of Social Class in Advanced Society." Theory and Society 25(5): 667-691.

Rose, Richard and Ian McAllister. 1986. Voters Begin to Choose: From Closed Class to Open Elections in Britain. Beverly Hills: Sage.

Savage, M. 2001. "Class Identity in Contemporary Britain: The Demise of Collectivism?" In: G. van Gyes a.o. eds. Can Class Still Unite: The Differentiated Work Force, Class Solidarity \& Trade Unions. Aldershot: Ashgate Publishing: 79-100.

Svallfors, Stefan. 1991. "The Politics of Welfare Policy in Sweden: Structural Determinants and Attitudinal Cleavages." British Journal of Sociology 42(4): 609-634.

Svallfors, Stefan. 1999. "The Class Politics of Swedish Welfare Policies." pp. 203-230 in The End of Class Politics? Class Voting in Comparative Context, edited by G. Evans. Oxford, UK: Oxford University Press.

Svallfors, Stefan. 2007. "Class and Attitudes to Market Inequality: A comparison of Sweden, Britain, Germany and the United States." pp. 189222 in The Political Sociology of the Welfare State, edited by S. Svallfors. Stanford: Stanford University Press.

Trommel, Willem, and Romke van der Veen. 1999. "De herverdeelde samenleving." pp. 13-22 in De herverdeelde samenleving; Ontwikkeling en herziening van de Nederlandse verzorgingsstaat, edited by W. Trommel and R. van der Veen. Amsterdam: Amsterdam University Press.

Turner, B.S. 1988. Status. Milton Keynes: Open University Press.

Van Oorschot, Wim. 200o. "De legitimiteit van sociale zekerheid; Een sociologische analyse van motieven voor solidariteit". pp. 35-76 in Sociale zekerheid: een ander gezichtspunt; Toekomstperspectief vanuit vier disciplines, edited by S. Klosse. Brugge, Belgium: die Keure.

Van Oorschot, Wim. 2002. "Individual Motives for Contributing to Welfare Benefits in the Netherlands." Policy and Politics 30(1): 31-46.

Visser, J. 2006. "Union membership statistics in 24 countries". Monthly Labor Review (January), 38-49.

Wright, Erik. O. (1985). Classes. London, UK: Verso. 


\title{
4 Labour Flexibility and Support for Social Security
}

\author{
Fabian Dekker
}

In Chapters two and three we investigated risk perception and the willingness to share risks using data from surveys among the Dutch population. The analysis of these survey data revealed some surprising facts. First, we learned that, contrary to theoretical expectations, welfare state support among the Dutch population is still high. However, this does not imply that they oppose welfare state reform. The norm of obligating reciprocity is strongly supported and therefore welfare state reform that reinforces this form of obligating reciprocity is also supported. Thirdly, and once again contrary to theoretical expectations, we discovered that individualisation does not necessarily undermine welfare state support. Individualisation not only strengthens the normative ideals of freedom and self-actualisation, it also makes people more aware of their vulnerability. It is this awareness of vulnerability that feeds welfare state support.

In this chapter, we once again investigate risk perception and the willingness to share risks in relation to processes of individualisation. In this chapter, we focus on the most important process of individualisation in relation to social security: the increase of labour flexibility. We make a distinction between different forms of labour flexibilisation and investigate how these forms of flexibilisation affect support for social security among the workers concerned. As in Chapter three, our conclusion is that some forms of labour flexibilisation do not undermine, but rather fuel support for social security. Again, it is an awareness of vulnerability, this time vulnerability in a more flexible labour market, that explains this. 
In recent decades, certain labour market developments have occurred in most industrialised western countries, such as a growing labour market participation of women and a concentration of the workforce in serviceoriented sectors. Against a background of rapid technological change and ongoing economic interdependence, the flexibilisation of labour markets has perhaps been one of the most fundamental changes to affect work and employment conditions in western economies (Kalleberg 2003; 2001; 200o). Likewise, flexibilisation of the labour market may have altered the risks people encounter, ultimately leading to an adaptation of social welfare services and provisions (Kemshall 2002). Views on the consequences of increasing labour market flexibility have been rather diverse up until now. Reflecting on this new flexible economy, some expect greater labour flexibility to lead to a decline in workers' dedication levels (Sennett 2006). Others, meanwhile, point to the joys and meaningfulness of contemporary work (De Botton 2009). 'Labour flexibility' is, however, a widelyused concept that can assume many different meanings. For example, the search for flexibility has resulted in more flexible or 'atypical' employment relationships. Nowadays, people's working lives are frequently characterised by temporary contracts, agency work and part-time employment. Flexible employment relationships allow workers to combine their work and private lives, but at the same time, 'atypical' employment patterns can create precarious employment situations and often expose workers to the risk of future job losses. Many commentators have addressed this issue in terms of rising employment instability and growing job insecurity in modern labour markets (Heery and Salmon 2000; Gorz 1999; Sennett 1998; Castells 1996).

In a flexible economy, having multiple skills becomes an important means of maintaining stable employment (Schmid 2006; Collins 2006). Therefore employees must be increasingly concerned with the continued improvement of their (flexible) skills in an attempt to remain employed. One potential way of managing these labour market risks is through 'functional flexibility', involving new work practices, such as job rotation, task rotation, job enlargement, job enrichment and (semi-autonomous) team working. In short, functional flexibility emphasises the development of multiple skills, which clearly has the potential to lessen labour market risks.

While many studies have examined the consequences of labour flexibility for how employees perceive risks at work, most have looked at 
'atypical' or flexible employment relationships and so-called 'internal job security' (see, for example, De Cuyper and De Witte 2006; De Witte and Näswall 2003). Studies that examine the relationship between different forms of labour flexibility and different aspects of job security are largely missing from the literature. The first aim of this study, therefore, is to examine the consequences of two types of labour flexibility - flexible employment relationships and functional flexibility - on employees' perceptions of security in both internal (inside the firm) and external (outside the firm) labour markets.

The second aim of this study is to focus on the specific relationship between job security and societal legitimacy of various policy arrangements. As far as risk coping is concerned, many political economists have assumed that job insecurity plays an important role in understanding individual policy preferences (Anderson and Pontusson 2007). Social security programmes generally compensate for certain risks, thereby protecting individuals in society. For example, the state provides benefits to people facing unemployment. At the individual level, one might expect work-insecure people to have strong incentives for supporting broad social security programmes, due to their higher risk of unemployment. However, little empirical evidence is available regarding the relationship between job security and public perceptions of social security. Although it is generally assumed that economic insecurity affects the need for social protection (Katzenstein 1985; Rodrik 1997; Iversen and Cusack 2000; Burgoon 2001), this remains an open empirical question at the individual level. This study addresses this lacuna.

Lastly, this chapter studies the relationship between labour flexibility, policy preferences and community feeling. Community feeling, or solidarity, can be another important motive people may have for supporting social security arrangements next to their own interests (Van Oorschot 2002a). We will examine whether flexible employment relationships generate less community feeling among individuals. In a similar way, we assess how functionally flexible work patterns affect individuals' sense of community. Although the literature provides us with several arguments regarding possible effects of labour flexibility on community feeling, to date, little empirical research has been undertaken on the subject.

Overall, this study demonstrates how 'atypical' and functionally flexible employees perceive different forms of job security and how their sense of community feeling will either increase or decrease. Furthermore, this study helps to explain support for various forms of social protection in the new flexible economy. Before introducing our data and results, we start by 
providing an overview of relevant theories on labour flexibility and policy preferences.

\section{Working in the new economy and policy preferences}

The experience of working in the post-industrial economy is considerably different from past experiences of work. For a start, there has been a shift in employment structures from manufacturing towards a service economy (see, for example, ILO 2006; Esping-Andersen 1993), and employment relations have become more flexible (see, for example, Dekker 2007; Auer and Cazes 2003). Nowadays, people's working lives are often characterised by 'atypical' forms of employment relationships such as temporary contracts, agency work and part-time employment. Taking the European Union (EU) as a whole, in $2007,14.5$ per cent of the total workforce had limited duration contracts, while approximately 18 per cent of employees considered themselves to be employed on a part-time basis.

Another feature of working in the contemporary labour market is the growing need to have multiple skills or the need for functional flexibility. Functionally flexible work practices can be extremely important when it comes to dealing with changing conditions in a more global economy. New flexible work arrangements, such as job rotation, task rotation and team working, are therefore increasingly being used in most European countries (OECD 1999). ${ }^{1}$ In 2005, for example, 47 per cent of all employees in the EU engaged in task rotation with their colleagues, while 6o per cent did part or all of their work in teams. Task rotation requires people to perform some tasks that lie outside the scope of their main job, while team working implies that more discretion is left to team members. Job rotation is another form of functional flexibility, and involves an employee moving from one position to another within an organisation.

In the remainder of this chapter, we focus on the Netherlands on the grounds that the Dutch workforce is one of the most flexible in Europe. As in many European countries, particularly due to the growing internationalisation of labour and capital since the beginning of the 1970s, flexible labour has become a central feature of the Dutch labour market (De Jong 2008). Approximately 18 per cent of workers in the Netherlands are employed in fixed-term positions and approximately 46 per cent of jobs are part-time. Furthermore, approximately 62 per cent of all Dutch workers engage in task rotation with colleagues and approximately 75 per cent participate in teams. 
Social security policies embody some kind of solidarity between (future) recipients of benefits and people who are less dependent on social programmes (De Beer and Koster 2009). At an individual level, people can have different motives for contributing to such programmes. People may be motivated by self-interest, or by feelings of moral or emotional commitment to others (Van Oorschot 2002a; 2002b; Van Oorschot and Komter 1998). However, largely missing from the literature is research that examines the implications of labour flexibility for individual policy preferences.

There are several ways in which labour flexibility could affect individual risk perception and policy preferences. For example, there is substantial evidence of increased job insecurity among 'atypical' workers. Our first hypothesis is, therefore, that workers with 'atypical' employment contracts experience less security at work. Although some authors find no correlation (Böckerman 2004), most of the literature suggests that there is indeed a relationship between 'atypical' employment and perceived job security (see, for example, Clark and Postel-Vinay 2005; De Witte and Näswall 2003; Green 2003). However, while most scholars focus on perceptions of internal job security, we differentiate between two types of job security here: company-specific or 'internal job security', and 'external job security', which is the possibility of finding a job outside the company. ${ }^{2}$ We expect that in both senses, 'atypical' employment contracts are associated with increased insecurity. On the one hand, the predetermined duration of the contract means flexible work carries a higher risk of unemployment in the near future. On the other hand, having to work for relatively short periods of time means 'atypical' employees are unable to develop their skills and credentials, which is likely to express itself in feelings of insecurity regarding possible employment outside the organisation.

\section{Hypothesis 1: Workers with flexible employment contracts experience} lower levels of internal and external job security than other workers.

While 'atypical' employment relationships may lead workers to experience lower levels of job security, functionally flexible employment may not have the same effect. Functional flexibility may offer employees an important means of obtaining multiple skills, thus making them feel less insecure. As suggested in the introduction, functionally flexible work practices may counter the risk of skill obsolescence. Functional flexibility is deemed necessary because of the fact that 'lifetime employment' is 
being replaced with the notion of 'flexible employment' (Forrier and Sels 2003; Moss Kanter 1993; 1991). Nowadays, so-called post-Fordist regimes are characterised by flexible career structures and people can no longer expect to have a stable, predictable career within the same organisation. In other words, people can no longer rely on organisations to provide them with traditional job security: 'jobs for life' are said to have disappeared and skills are becoming obsolete. Workers are increasingly reliant upon the need for multiple skills; that is, their employability (Moss Kanter 1993). One way to ensure 'employability-security' in the modern labour market is to create challenging jobs and to allow employees to engage in assignment rotation (Moss Kanter 1991). In that sense, the development of functionally flexible jobs could offer employees opportunities to acquire multiple skills to exercise more control over their work than in the past.

While some remain sceptical about functional flexibility and point to the possible exploitation of employees by employers (Hyman 2004) or the 'time-greedy' nature of the high-performance workplace (Van Echtelt 2007), functional flexibility does have the potential to offer employees new 'employability-security' in the labour market. This would mean that functionally flexible workers would experience more job security than workers without flexible job features. Although empirical evidence is scarce, a recent study by Kashefi (2007) shows that in the United States, in general, employees who are functionally flexible experience higher levels of job security. In this chapter, we examine this relationship between functional flexibility and perceived job security. Again, our research distinguishes between two types of job security: 'internal job security' and 'external job security'. We expect functionally flexible work practices to be associated with increased feelings of security at work in both regards. First, functionally flexible workers are more adaptable in their response to demands and are therefore more valuable to organisations. Such workers are unlikely to believe that they would be made redundant in the near future. Second, these workers are also likely to feel more secure in the external labour market because enhancing their knowledge and skills is likely to cause them to feel more 'marketable'. This, in turn, leads to our second hypothesis:

Hypothesis 2: Functionally flexible workers experience higher levels of internal and external job security than other workers.

Labour flexibility is not only related to perceived job security but to policy preferences as well. However, empirical evidence on the relationship be- 
tween labour flexibility and support for welfare state policies is largely lacking at the micro level. As we have seen in the previous chapters, several authors argue that social arrangements must be legitimised by the public to remain sustainable in the long run (see, for example, Burstein 1998). An important foundation underlying this support is self-interest (see, for example, Hechter 1987). The basic idea is that there is a direct relationship between someone's position in the stratification structure and their support for social security. Following this self-interested perspective, we would not expect secure workers to be likely beneficiaries of social security protection. In other words, people who do not face labour market risks, such as unemployment, are unlikely to protect themselves against these risks by taking out social insurance. Hence, these work-secure individuals are less likely to support public spending on social security. Building on this logic, we hypothesise that this is especially true with regard to spending on unemployment benefits. Insecurity at work is not related to preferences about welfare programmes which are unrelated to the importance of income protection during working life, such as pensions or healthcare. ${ }^{3}$ This, in turn, leads to two additional hypotheses:

\section{Hypothesis 3: Experiencing internal and external job security is nega- tively related to an individual's support for unemployment benefits.}

Hypothesis 4: Experiencing internal and external job security is not related to support for other social security programmes (pensions and healthcare).

\subsection{Labour flexibility, community feeling and policy preferences}

As noted in the introduction, labour flexibility can influence individuals' sense of community, which in turn can affect policy preferences. Although individual support for social security is most strongly affected by perceived self-interest (Van Oorschot 2002a; 2002b), the experience of 'shared identity' is also a relevant predictor of policy preferences (Van Oorschot 2002a; 2002b; Van Oorschot and Komter 1998). This type of motivation is grounded in Durkheim's classical approach to sociology (Durkheim 1964), which suggests that a perceived connection with others spurs solidaristic behaviour (Polletta and Jasper 2001). However, following Richard Sennett (1998) and Zygmunt Bauman (2001), we may assume that 'atypical' forms of employment relationships have negative consequences for this sense of community. ${ }^{4}$ In their view, the erosion of long- 
term employment contracts undermines loyalty, trust and the sense of belonging to a wider collectivity. The 'new' short-term, unstable labour market simply leaves no room for long-term social relations and mutual commitments. In the flexible economy, there is no 'shared fate' (Sennett 1998: 147), which makes an understanding of community difficult. According to Bauman (2001: 24-25), the flexible labour market ' (...) feels like a camping site which one visits for but a few nights and which one may leave at any moment if the comforts on offer are not delivered or found wanting when delivered (...)'. Furthermore, flexible labour is associated with uncertainties and risks and is expected to be a strong 'individualizing force': 'It divides instead of uniting, and since there is no telling who might wake up in what division, the idea of 'common interests' grows ever more nebulous and in the end becomes incomprehensible' (Bauman 2001: 24). Our fifth hypothesis tests this claim:

\section{Hypothesis 5: Workers with flexible employment contracts report lower levels of community feeling than other workers.}

Once again, we expect that the situation for functionally flexible workers will differ from that of 'atypical' workers. It has been argued that functional flexibility has brought more individual responsibility and an increasing shift towards self-management (Amoore 2002), which results in less commitment towards others (Ezzy 2001). However, most of the literature states that functional flexibility requires workers to cooperate and communicate more to achieve mutual goals than was the case in 'traditional' Taylorist organisations (European Foundation for the Improvement of Living and Working Conditions 2007a; Hempell and Zwick 2005), which may improve the likelihood of people feeling a sense of community. While 'Taylorism' included no extensive job-learning opportunities and a high technical division of labour, functional flexibility emphasises employees' learning possibilities and common goals. We therefore assume that working for a so-called 'holistic' organisation ${ }^{5}$ (Lindbeck and Snower 200o) enhances an employee's sense of belonging to a wider collectivity; people may learn more about co-workers and their work, and experience more collective tasks and needs. In other words, while workers with 'atypical' labour contracts may be less likely to develop a sense of community feeling, it can be expected that working in a functionally flexible work environment creates a sense of community feeling. We will call this the 'integration scenario': 
Hypothesis 6: Functionally flexible workers report higher levels of community feeling than other workers.

Because previous research has shown that community feeling is positively related to individual support for social security arrangements, we also assume that community feeling positively affects support for different social security programmes:

\begin{abstract}
Hypothesis 7: Community feeling is positively related to an individual's support for social security programmes (unemployment, pensions and healthcare).
\end{abstract}

\title{
3 Data and measures
}

The data in this study are taken from the 'Labour and Welfare Opinions' survey, and were collected by Centre Data at Tilburg University in the Netherlands in May and June 2006. This data set concerns a random sample of the Dutch population aged 16 and over. The sample comprises 1,801 valid cases, which corresponds to a response rate of 77 per cent. After inactive people (the unemployed, students and retired workers) and the self-employed have been excluded from the sample, ${ }^{6}$ the survey contains data on 945 respondents. The data have been weighted against figures from Statistics Netherlands (Centraal Bureau voor de Statistiek, or CBS). After weighting for age, education and income levels, the dataset can be considered representative for the Netherlands.

The first step of our analysis was to test the hypotheses concerning 'atypical' employment and functional flexibility and perceived security at work empirically. Flexible employment contracts include employees with fixed-term contracts, agency workers and on-call workers (1); all other jobs are non-flexible, including fixed-term jobs that offer the prospect of permanent employment (o). While we are fully aware that flexible workers are not a homogenous group (Connelly and Gallagher 2004; Gallie et al. 1998), it was not possible to distinguish different types of flexible employees statistically. Furthermore, part-time work is not classified as flexible employment because this type of employment can no longer be considered as 'atypical' in the Netherlands (Schulze Buschoff and Protsch 2008). According to Visser (2002: 33), 'most part-time employees are covered by collective agreements and most part-time jobs (...) are standard jobs of indeterminate length, subject to full dismissal protection' in the 
Netherlands. Functional flexibility was measured using two single items, task rotation and job rotation, which cover important forms of functional flexibility (unfortunately, no items were dedicated to teamwork, job enlargement and job enrichment in the questionnaire). ${ }^{7}$ Internal and external job security are defined as an individual assessment of an employment situation. While perceived insecurity may not reflect actual risks, 'subjective insecurity' is at least as severe as 'objective insecurity' (Lazarus 1991). Internal job security was measured as the individual's perception of the likelihood of remaining employed over the next twelve months. We used one central indicator of external job security, based on the question: 'To what degree do you agree or disagree with the following statement: I have enough skills and experience to find another job without any difficulty.'

With regard to perceived internal and external job security, several control variables were included in the analysis. We included age as a control variable because levels of perceived job security are likely to differ among age groups. Previous research has shown that older employees experience higher levels of job insecurity (Hartley, Jacobsen, Klandermans and Van Vuuren 1991). We anticipated that a person's level of education might also be associated with perceptions of job security (Sverke, Hellgren and Näswall 2006). ${ }^{9}$ Gender is another factor that may influence perceptions of security at work, but this remains a point of debate (Sverke, Hellgren and Näswall 2006). In addition, working in the private sector decreases the likelihood of job security (Clark and Postel-Vinay 2005), therefore we control for sectoral differences between public and private sector employment. We also created a dummy variable for ethnicity to determine whether immigrant workers feel more insecure. Furthermore, we were interested in the influence of household income levels on job security. One might expect people living in households with higher income levels to feel less insecure (Sverke, Hellgren and Näswall 2006). Moreover, because we are interested in attitudes towards public spending, we control for benefit dependency. In relation to job security, we assumed that people who had received no social security transfers in the past were more work-secure than workers with a history of receiving benefits. Finally, one would expect people who feel that they have no control over their lives to be more insecure (Ashford, Lee and Bobko 1987)..$^{10}$ In the next step of the analysis, we tested the hypotheses on community feeling. ${ }^{11}$ In addition to the other control variables, we included political preference as a control factor. In general, it can be expected that people on the political left adhere more to the collective than individuals on the right (Van Oorschot 2002a). Finally, we used support for different social security programmes as the dependent variable. ${ }^{12}$ All effects were calculated using multiple regression models. 


\section{$4 \quad$ Results}

The results of our analyses are presented in Table 1.

Table 1 Support for spending on social security programmes

\begin{tabular}{|c|c|c|c|c|c|c|}
\hline Dependent variable & $\begin{array}{l}\text { Internal } \\
\text { job security }\end{array}$ & $\begin{array}{l}\text { External } \\
\text { job secu- } \\
\text { rity }\end{array}$ & $\begin{array}{l}\text { Commu- } \\
\text { nity } \\
\text { feeling }\end{array}$ & $\begin{array}{l}\text { Unem- } \\
\text { ployment }\end{array}$ & Pensions & $\begin{array}{l}\text { Health- } \\
\text { care }\end{array}$ \\
\hline \multicolumn{7}{|l|}{ Explanatory variables } \\
\hline Task rotation & -0.026 & $0.183^{* * *}$ & -0.054 & 0.020 & 0.027 & 0.010 \\
\hline Job rotation & -0.018 & $0.074^{*}$ & 0.015 & -0.016 & 0.048 & 0.022 \\
\hline $\begin{array}{l}\text { Type of contract }(1= \\
\text { flexible) }\end{array}$ & $-0.288^{* * *}$ & 0.004 & 0.018 & -0.022 & -0.010 & -0.024 \\
\hline Age (actual age) & $-0.076^{*}$ & $-0.111^{* *}$ & $0.157^{* * *}$ & $0.078^{*}$ & $0.081^{*}$ & $0.101^{*}$ \\
\hline \multicolumn{7}{|l|}{$\begin{array}{l}\text { Education (ref = } \\
\text { lower general and } \\
\text { vocational education) }\end{array}$} \\
\hline $\begin{array}{l}\text { Secondary general } \\
\text { and secondary } \\
\text { vocational }\end{array}$ & $-0.107^{*}$ & 0.017 & -0.034 & $-0.102^{*}$ & -0.010 & -0.011 \\
\hline $\begin{array}{l}\text { Higher vocational and } \\
\text { university education }\end{array}$ & -0.044 & $0.097^{*}$ & -0.038 & $-0.166^{* * *}$ & $-0.210^{* * *}$ & $-0.128^{*}$ \\
\hline Gender ( 1 = female $)$ & $-0.070^{*}$ & -0.049 & -0.024 & 0.008 & 0.061 & 0.043 \\
\hline Sector (1 = private) & $-0.070^{*}$ & 0.025 & -0.015 & $-0.096^{*}$ & -0.014 & $-0.106^{* * *}$ \\
\hline $\begin{array}{l}\text { Ethnicity ( } 1=\text { born } \\
\text { outside Netherlands) }\end{array}$ & $-0.083^{*}$ & -0.020 & -0.043 & 0.015 & 0.042 & 0.051 \\
\hline $\begin{array}{l}\text { Net household } \\
\text { income }\end{array}$ & 0.020 & -0.063 & -0.031 & $-0.119^{* * *}$ & -0.037 & -0.044 \\
\hline $\begin{array}{l}\text { Benefit dependency } \\
(1=\text { no dependency) }\end{array}$ & $0.134^{* * * *}$ & 0.062 & 0.017 & -0.012 & 0.033 & 0.044 \\
\hline $\begin{array}{l}\text { External locus of } \\
\text { control }\end{array}$ & $-0.125^{* * * *}$ & $-0.172^{* * * *}$ & 0.027 & -0.044 & $0.103^{* *}$ & -0.021 \\
\hline $\begin{array}{l}\text { Political preference } \\
(1=\text { political left, } 11 \\
=\text { right })\end{array}$ & & & $-0.254^{* * *}$ & $-0.139^{* * *}$ & 0.012 & $-0.094^{*}$ \\
\hline Internal job security & & & & $-0.083^{*}$ & -0.021 & -0.050 \\
\hline External job security & & & & 0.030 & 0.038 & 0.043 \\
\hline Community feeling & & & & $0.260^{* * *}$ & $0.092^{*}$ & 0.068 \\
\hline $\mathrm{N}$ & 785 & 775 & 779 & 710 & 715 & 715 \\
\hline Adjusted R-squared & .12 & .11 & .09 & .15 & .06 & .04 \\
\hline
\end{tabular}

Significant coefficients (standardised effects): ${ }^{*} p<0.05 ;{ }^{* *} p<0.01 ;{ }^{* * *} p<0.001$ 
In line with our first hypothesis, people with 'atypical' employment contracts feel less secure in their current jobs. Being an 'atypical' worker is related to a decrease of perceived internal job security (0.288). This finding corroborates results from earlier studies: job insecurity is greater among 'atypical' workers (e.g. Heery and Salmon 200o). However, our findings also indicate there is no relationship between the type of employment contract and external job security. This means that flexible and permanent workers are not distinct from one another in their external job security expectations. Our first hypothesis, that workers with flexible employment contracts experience lower levels of internal and external job security, is thus partially confirmed.

This contrasts with the findings on functional flexibility: while functionally flexible workers consider themselves more 'employable' on the external labour market, there is no effect on their future career expectations regarding the internal labour market. Thus, our second hypothesis, that functionally flexible workers experience higher levels of internal and external job security, is also partly confirmed. A possible explanation for these findings is that these workers experience functionally flexible work practices as primarily designed to make them more capable of switching between jobs, and having little to do with their security in the internal labour market.

Other significant predictors of job security are age (older people feel less secure in both internal and external labour markets) and education (individuals who have completed secondary general and secondary vocational education feel less secure in their jobs than people with lower educational levels, a result that is somewhat unexpected). One possible explanation for this latter finding is that less well-educated workers have already accepted, as a way of coping with the situation, that they are more vulnerable in the internal labour market. However, more research is needed to determine the validity of this argument. In addition, we found the following: individuals with higher vocational and university qualifications feel more secure in the external labour market; women feel more insecure in their current jobs; employees working in the private sector feel less internally work-secure; individuals who were born outside the Netherlands experience more internal job insecurity; not being dependent on benefits has a positive impact on an individual's perception of their internal security; and individuals with an external locus of control feel more insecure in both labour markets. In general, the findings on 'internal job security' are consistent with findings from previous studies discussed above. The most interesting finding, however, is that different types of labour flex- 
ibility are associated with different forms of perceived security at work. Previous studies focused mainly on 'atypical' forms of employment and 'internal job security'. In doing so, these studies have largely ignored the importance of differentiating between internal and external job security. The findings presented here demonstrate the necessity of doing so.

With regard to our third and fourth hypotheses, that experiencing job security is negatively related to support for unemployment insurance and not related to support for other social security programmes, we see that feelings of security at work are not related to individual support for welfare spending in the case of pensions or healthcare. We also find that internal job security has a significant and expected effect on support for unemployment spending. However, external job security does not affect support for unemployment spending. This result implies once again that differentiation between types of job security is important and must also be included in studies that explain people's opinions on welfare spending. Previous research into economic insecurity and political attitudes does not link different forms of job insecurity to support for different aspects of social security.

We now turn to the effects of labour flexibility on community feeling. Many social scientists assume that workers with flexible employment contracts are less inclined to support the notion of collective interests. Our data does not support this view. The data presented in Table 1 show there is no association between contract type and community feeling, meaning we should reject our fifth hypothesis. In contrast, we do see significant differences based on age and political beliefs. Older people show higher levels of community feeling, while individuals on the right of the political spectrum show lower levels of community feeling. Van Oorschot (2002a; $2002 b)$ finds similar results. Furthermore, the results show that the level of community feeling does not increase when individuals are functionally flexible; hypothesis six is thus rejected. In other words, there is no empirical evidence to support the notion that working in 'holistic' or integrative work settings is associated with a heightened sense of community feeling.

The results also show that in general, community feeling is a significant source of motivation for supporting social security arrangements. ${ }^{13}$ This means that our last hypothesis is confirmed, in line with the existing literature. The data also reveal a number of significant effects with our control variables. Older people are more inclined to support social security spending in all three areas and more highly-educated individuals show lower levels of support for unemployment, pensions and healthcare. In addition, private sector workers show less support for spending in the 
areas of unemployment and healthcare and higher net household income levels negatively affect support for spending on unemployment benefits. Individuals' sense of control in their lives is also significantly associated with policy preferences (individuals with an external locus of control are more in favour of spending in the case of pensions). Finally, political preference is significant as people on the political right are less inclined to support spending on unemployment and healthcare. These results are in accordance with the findings of earlier studies on attitudes towards welfare state policies (see, for example, Yang and Barrett 2006; Blekesaune and Quadagno 2003; Shivo and Uusitalo 1995; Pettersen 1995).

\section{Conclusions and discussion}

The aim of this chapter was to examine the impact of labour flexibility on job security, levels of community feeling and policy preferences. Although these links have been widely discussed in the literature, very little empirical research exists to support such discussions. The findings presented here move research in this area forward by pointing to the importance of differentiating between internal and external job security. Our empirical results show that internal job security is negatively related to the type of employment contract, while external job security is positively related to functional flexibility. At the theoretical level, these findings suggest that labour flexibility creates different categories of workers: 'atypical' (internal) insecure employees and a multi-skilled workforce that perceives (external) security. This finding corresponds to the different strategies employed by 'the flexible firm' (Atkinson 1984); that is, the notion that flexible organisations feature a functionally flexible core and an 'atypical' peripheral workforce.

Differences also exist with regard to types of job security and support for social security spending. We found internal job security to have a significant negative effect on support for spending on unemployment benefits. This negative link between internal job security and preferences for unemployment benefits spending can be seen as a rational decision made by work-secure people. However, a comparison of external work-secure and work-insecure individuals revealed no significant differences in support levels. One possible explanation for this that draws on cognitive decision theories is that people pay more attention to the (consequences of) risks in the near future (the chance of becoming unemployed in the next twelve months) than to long-term risk situations (the possibility of find- 
ing a new job) (for the literature on evaluating risks, see Kahneman and Tversky 1974). We also presented evidence that shows labour flexibility is not related to community feeling. This suggests that community feeling is neither being eroded ('atypical' employment) nor increasing (functional flexibility) in the new, flexible economy.

In sum, labour flexibility brings both opportunities and risks for employees. As far as the welfare state is concerned, labour market flexibility spurs support for unemployment spending, due to higher levels of internal job insecurity. Because public opinion seems to matter when it comes to the expansion of the welfare state (Brooks and Manza 2007; 2006; Burstein 1998; Page and Shapiro 1983), it can be expected that in times of increased labour flexibility, individuals are likely to demand higher levels of spending on unemployment benefits. Depending on whether individual policy preferences are represented by larger groups, such as trade unions or political parties, policy-makers may consider no further expenditure retrenchment regarding the risk of unemployment. As we have seen, the changing nature of work shapes workers' perceptions of risks, fostering a growing need for risk reduction through social policy. While TaylorGooby (see Chapter 1) seems to argue that the process of increasing labour market flexibility seems to spawn some sort of new welfarism, in which social spending is only feasible as investments in human capital, and where others like Giddens (1998), in a similar vein, write about social investment states, for the flexible workforce under observation here, we continue to find evidence for support of old welfarism - because workers are internally flexible, their internal job insecurity leads them to support old welfare benefits.

\section{Notes}

1 Job enrichment and job enlargement are two other characteristics of functional flexibility. However, questions used to obtain data on these two types of functional flexibility are generally lacking in available comparative survey data.

2 See also Groot and Maassen van den Brink (2000).

3 Macro-level research in this area indeed indicates that economic insecurity affects support for public spending (Katzenstein 1985; Rodrik 1997; Iversen and Cusack 20oo; Burgoon 2001). At the individual level, meanwhile, some studies provide information on specific labour market risks and policy preferences. Cusack et al. (2006), Kramer and Stephenson (2001) and Iversen and 
Soskice (2001) point out that working in occupations with higher unemployment rates and a higher level of skill specificity spurs support for government redistribution. Nevertheless, with these few exceptions, the micro-level picture remains largely unstudied (see, for example, Scheve and Slaughter 2004), as does, in particular, the relationship between individuals' insecurities about their jobs and policy preferences. However, several other studies include 'class position' as a factor in work on policy preferences (see, for example, Svallfors, 2003; 1997; 1995).

4 In this study, we refer to the experienced shared connection among citizens within one country. At the organisational level, Koster (2005) has shown that 'atypical' and permanent workers do not differ in their solidarity toward coworkers.

5 The 'holistic' organisation is defined by a lower task specialisation among workers, featuring job rotation, integration of tasks and learning across tasks (Lindbeck and Snower, 200o).

6 In explaining self-perceived job security, these groups are not included because they are not employed by organisations.

7 We measured task rotation by asking employees how often they had been shifted towards tasks that lay outside their own job descriptions during the last twelve months $(1=$ never, $2=$ seldom, $3=$ sometimes, $4=$ often, $5=$ very often). Job rotation was measured by asking how often they had been shifted between jobs during the last twelve months $(1=$ never, $2=$ seldom, $3=$ sometimes, $4=$ often, 5 = very often).

81 = strongly disagree, $2=$ disagree, $3=$ neither agree nor disagree, $4=$ agree, 5 = strongly agree.

9 We thus created two dummy variables: one for secondary general and secondary vocational education and one for higher vocational and university education. Workers with lower general and vocational education levels formed the reference category.

10 This external locus of control was measured by a scale of three items (alpha reliability $=.75$ ), which focused on a individual's perception that they have no control over their own personal life $(1=$ totally disagree, $2=$ disagree, $3=$ agree nor disagree, 4 = agree, $5=$ totally agree) .

11 Community feeling was defined using the statement: 'For me, paying social insurance premiums is something that I do because I personally sympathise with the beneficiaries and their situations' ( $1=$ totally disagree, $2=$ disagree, 3 $=$ agree nor disagree, 4 = agree, $5=$ totally agree). Although the notion of 'community feeling' can be defined in various ways (McMillan and Chavis George 1986), our measure seems to be common in research on attitudes towards social security spending (see, for example, Van Oorschot 2002a; 2002b). 
12 We used survey questions about support for spending on unemployment benefits, pensions and healthcare. The following question was asked: 'Would you like to see more, the same, or less government spending in the case of unemployment/pensions/healthcare? Remember that if you say more, this will require an increase in taxation' $(1=$ spend much less, $2=$ spend less, $3=$ spend the same as now, $4=$ spend more, $5=$ spend much more).

13 Although support for healthcare spending is significant at the 10 per cent level (not shown).

\section{References}

Amoore, Louise. 2002. Globalisation contested: an international political economy of work. Manchester: Manchester University Press.

Anderson, Christopher J. and Jonas Pontusson. 2007. "Workers, worries and welfare states: Social protection and job insecurity in 15 OECD countries." European Journal of Political Research, 46: 211-235.

Ashford, Susan J., Cynthia Lee and Philip Bobko. 1987. Job insecurity: An empirical analysis of three measures. Presented at the Annual Meeting of the Academy of Management, New Orleans.

Atkinson, John. 1984. "Manpower strategies for flexible organizations." Personnel Management, 16: 28-31.

Auer, Peter and Sandrine Cazes, eds. 2003. Employment Stability in the Age of Flexibility: Evidence From Industrialized Countries. Geneva: ILO.

Bauman, Zygmunt. 2001. The individualized society. Cambridge: Polity Press.

Beck, Ulrich. 200o. The Brave New World of Work. Cambridge: Polity Press.

Berntson, Erik, Magnus Sverke and Staffan Marklund. 20o6. "Predicting Perceived Employability: Human Capital or Labour Market Opportunities?" Economic and Industrial Democracy, 272: 223-244.

Blekesaune, Morten and Jill Quadagno. 2003. "Public Attitudes toward Welfare State Policies: A Comparative Analysis of 24 Nations." European Sociological Review, 195: 415-427.

Böckerman, Petri. 2004. "Perception of job instability in Europe." Social Indicators Research, 67: 283-314.

Bredgaard, Thomas, Flemming Larsen, Per Kongshøj Madsen and Stine Rasmussen. 2009. Flexicurity and atypical employment in Denmark. Aalborg: CARMA Research Paper 2009: 01. 
Brooks, Clem and Jeff Manza. 2007. Why Welfare States Persist: The Importance of Public Opinion in Democracies. Chicago: The University of Chicago Press.

Brooks, Clem and Jeff Manza. 2006. "Why Do Welfare States Persist?" The Journal of Politics, 684: 816-827.

Burgoon, Brian. 2001. "Globalization and Welfare Compensation: Disentangling the Ties that Bind." International Organization, 553: 509-551.

Burstein, Paul. 1998. "Bringing the Public Back In: Should Sociologists Consider the Impact of Public Opinion on Public Policy?" Social Forces, 771: 27-62.

Castells, Manuel. 1996. The Rise of the Network Society. Oxford: Blackwell Publishers.

CBS. 2008. Werkloosheid vrijwel onveranderd. Persbericht 17 juli 2008. Voorburg/Heerlen: CBS.

Clark, Andrew and Fabien Postel-Vinay. 2005. Job security and job protection. IZA Discussion Paper 1489. Bonn: IZA.

Collins, Hugh. 2006. "Flexibility and stability of expectations in the contract of employment." Socio-Economic Review, 4: 139-153.

Connelly, Catherine E. and Daniel G. Gallagher. 2004. "Emerging Trends in Contingent Work Research." Journal of Management, 306: 959-983.

Cusack, Thomas, Torben Iversen and Phillip Rehm. 2006. "Risks at work: the demand and supply sides of government redistribution." Oxford Review of Economic Policy, 223: 365-389.

De Beer, Paul and Ferry Koster. 2009. Sticking Together or Falling Apart. Amsterdam: Amsterdam University Press.

De Botton, Alain. 2009. Ode aan de arbeid. Amsterdam: Atlas.

De Cuyper, Nele and Hans de Witte. 2006. "The impact of job insecurity and contract type on attitudes, well-being and behavioural reports: A psychological contract perspective." Journal of Occupational and Organizational Psychology, 79: 395-409.

Dekker, Ronald. 2007. Non-standard employment and mobility in the Dutch, German and British labour market. Tilburg: Tilburg University.

De Witte, Hans, ed. 2005. Job insecurity, union involvement and union activism. Aldershot: Ashgate.

De Witte, Hans and Katharina Näswall. 2003. 'Objective' vs 'Subjective' Job Insecurity: Consequences of Temporary Work for Job Satisfaction and Organizational Commitment in Four European Countries." Economic and Industrial Democracy, 242: 149-188.

DNB. 2008. Economische ontwikkelingen. Kwartaalbericht september 2008. Amsterdam: DNB. 
Durkheim, Emile. 1964. The Division of Labor in Society. New York: Free Press.

Esping-Andersen, Gösta, ed. 1993. Changing Classes. Stratification and mobility in post-industrial societies. London: Sage.

Esping-Andersen, Gösta. 1990. The Three Worlds of Welfare Capitalism. Princeton: Princeton University Press.

European Foundation for the Improvement of Living and Working Conditions. 2007a. Teamwork and high performance work organization. Dublin: European Foundation for the Improvement of Living and Working Conditions.

European Foundation for the Improvement of Living and Working Conditions 2007b. Fourth European Working Conditions Survey. Dublin: European Foundation for the Improvement of Living and Working Conditions.

Ezzy, Douglas. 2001. "A Simulacrum of Workplace Community: Individualism and Engineered Culture." Sociology, 353: 631-650.

Forrier, Anneleen and Luc Sels. 2003. "Temporary employment and employability: Training opportunities and efforts of temporary and permanent employees in Belgium." Work, Employment \& Society, 174: 641-666.

Gallie, Duncan. 2007. "Production Regimes and the Quality of Employment in Europe." Annual Review of Sociology, 33: 85-104.

Gallie, Duncan and Serge Paugam, eds. 200o. Welfare Regimes and the Experience of Unemployment in Europe. Oxford: Oxford University Press.

Gallie, Duncan, Michael White, Yuan Cheng and Mark Tomlinson. 1998. Restructuring the Employment Relationship. Oxford: Clarendon Press. Giddens, Anthony. 1998. The Third Way. Cambridge: Polity Press

Godard, John. 2001. "High Performance and the Transformation of Work? The Implications of Alternative Work Practices for the Experience and Outcomes of Work." Industrial and Labor Relations Review, 544: 776-805.

Gorz, André. 1999. Reclaiming Work. Beyond the Wage-Based Society. Cambridge: Polity Press.

Green, Francis. 2003. The Rise and Decline of Job Insecurity. Department of Economics Discussion Paper. Canterbury: University of Kent.

Groot, Wim and Henriette Maassen van den Brink. 20oo. "Education, Training and Employability." Applied Economics, 32: 573-581.

Hall, Peter A. and David Soskice, eds. 2001. Varieties of Capitalism. The Institutional Foundations of Comparative Advantage. Oxford: Oxford University Press. 
Hartley, Jean, Dan Jacobsen, Bert Klandermans and Tinka van Vuuren. 1991. Job insecurity: Coping with jobs at risk. London: Sage.

Hechter, Michael. 1987. Principles of Group Solidarity. Berkeley: University of California Press.

Heery, Edmund. and John Salmon, eds., 200o. The insecure workforce. London: Routledge.

Hempell, Thomas and Thomas Zwick. 2005. Technology Use, Organisational Flexibility and Innovation: Evidence for Germany. Discussion paper, Centre for European Economic Research ZEW.

Hyman, Richard. 2004. "An emerging agenda for trade unions?" In: Munck, R. ed., Labour and Globalisation: Results and Prospects. Liverpool: Liverpool University Press.

ILO. 2006. Global employment trends brief, January 20o6. Geneva: ILO.

Iversen, Torben and Thomas Cusack. 200o. "The cause of welfare state expansion." World Politics, 523: 313-349.

Iversen, Torben and David Soskice. 2001. "An Asset Theory of Social Policy Preferences." The American Political Science Review, 954: 875-893.

Jong, Jeroen de. 2008. A matter of time. Mechanisms behind fair treatment perceptions in temporary employment. Tilburg: Tilburg University.

Kahneman, Daniel and Amos Tversky. 1974. "Judgement under uncertainty: heuristics and Biases." Nature, 185: 1124-1131.

Kalleberg, Arne. 2003. "Flexible Firms and Labor Market Segmentation: Effects of Workplace Restructuring on Jobs and Workers." Work and Occupations, 302: 154-175.

Kalleberg, Arne. 2001. "Organizing Flexibility: The Flexible Firm in a New Century." British Journal of Industrial Relations, 394: 479-504.

Kalleberg, Arne. 20oo. "Nonstandard Employment Relations: Part-time, Temporary and Contract Work." Annual Review of Sociology, 26: 341365 .

Kashefi, Max. 2007. "Work flexibility and its individual consequences." Canadian Journal of Sociology, 323: 341-369.

Katzenstein, Peter J. 1985. Small States in World Markets. New York: Cornell University Press.

Kemshall, H. 2002. Risk, social policy and welfare. Buckingham: Open University Press.

Koster, Ferry. 2005. For the time being: Accounting for inconclusive findings concerning the effects of temporary employment relationships on solidary behaviour of employees. Veenendaal: Universal Press.

Kramer, Claire and Laura Stephenson. 2001. Opposing Forces: Economic Theory, Domestic Institutions and Insecurity in the Global Economy. 
Paper prepared for the Midwest Political Science Association Conference, Chicago.

Lazarus, Richard S. 1991. Emotion and adaptation. New York: McGraw Hill. Lindbeck, Assar and Dennis Snower. 20oo. "Multitask Learning and the Reorganization of Work: From Tayloristic to Holistic Organization." Journal of Labor Economics, 183: 353-376.

Marks, Abigail and Dora Scholarios. 2008. "Choreographing a System: Skill and Employability in Software Work." Economic and Industrial Democracy, 291: 96-124.

McMillan, David W. and David Chavis George. 1986. "Sense of Community: A Definition and Theory." Journal of Community Psychology, 14: 6-23.

Moss Kanter, Rosabeth. 1993. "Employability Security." Business and Society Review, 87: 9-17.

Moss Kanter, Rosabeth. 1991. "Globalism/Localism: A New Human Resources Agenda." Harvard Business Review, March-April, 9-10.

OECD. 1999. Employment Outlook. Paris: OECD.

Page, Bejamin I. and Robert Y. Shapiro. 1983. "Effects of Public Opinion on Policy." American Political Science Review, 771: 175-19o.

Pettersen, Per Arnt. 1995. "The Welfare State: The Security Dimension." pp. 198-233 in The Scope of Government. New York: Oxford University Press.

Polavieja, Javia G. 2005. "Flexibility or polarization? Temporary employment and job tasks in Spain." Socio-Economic Review, 3: 233-258.

Polletta, Francesca and James M. Jasper. 2001. "Collective Identity and Social Movements." Annual Review of Sociology, 27: 283-305.

Rodrik, Dani. 1995. "Political Economy of Trade Policy." Pp. 1457-1494 in Handbook of International Economics, Volume 3, Netherlands: Elsevier.

Scheve, Kenneth F. and Matthew J. Slaughter. 2004. "Economic Insecurity and the Globalization of Production." American Journal of Political Science, 484: 662-674.

Schmid, Gunther. 2006. "Social risk management through transitional labour Markets." Socio-Economic Review, 4: 1-33.

Schulze Buschoff, Karin and Paula Protsch. 2008. "A-typical and in-secure? Social protection and 'non-standard' forms of employment in Europe." International Social Security Review, 614: 51-73.

Sennett, Richard. 2006. The Culture of the New Capitalism. London: Yale University Press.

Sennett, Richard. 1998. The Corrosion of Character. The Personal Consequences of Work in the New Capitalism. New York: W.W. Norton and Company. 
Shivo, Tuire and Hanna Uusitalo. 1995. "Economic Crisis and Support for the Welfare State in Finland 1975-1993." Acta Sociologica, 38: 251-262.

Svallfors, Stefan. 2003. "Welfare regimes and welfare opinions: A comparison of eight Western countries." Social Indicators Research, 643: 495-520.

Svallfors, Stefan. 1997. "Worlds of Welfare and Attitudes to Redistribution: A Comparison of Eight Western Nations." European Sociological Review, 13: 283-304.

Svallfors, Stefan. 1995. "The End of Class Politics? Structural Cleavages and Attitudes to Swedish Welfare Policies." Acta Sociologica, 38: 53-74.

Sverke, Magnus, Johnny Hellgren and Katharina Näswall. 2006. Job insecurity: A literature review. Stockholm: Saltsa.

Van Echtelt, Patrica. 2007. Time-greedy employment relationships. Four studies on the time claims of post-Fordist work. Groningen: RuG.

Van Oorschot, Wim. 2002a. "Popular Support for Social Security. A sociological perspective." Pp. 33-52 in What future for social security? Bristol: The Policy Press.

Van Oorschot, Wim. 2002b. "Individual motives for contributing to welfare benefits in the Netherlands." Policy \& Politics, 301: 31-46.

Van Oorschot, Wim, and Aafke Komter. 1998. "What is it that ties...? Theoretical perspectives on social bond." Sociale Wetenschappen, 413: 5-24.

Vis, Barbara, Kees van Kersbergen and Uwe Becker. 2008. "The Politics of Welfare State Reform in the Netherlands: Explaining a Never-Ending Puzzle." Acta Politica, 43: 333-356.

Visser, Jelle. 2002. "The first part-time economy in the world: a model to be followed?" Journal of European Social Policy, 121: 23-42.

Yang, Philip and Nadine Barrett. 2006. "Understanding public attitudes towards Social Security." International Journal of Social Welfare, 15: 95-109. 


\title{
$5 \quad$ Increasing Employability
}

\section{The Conditions for Success of an Investment Strategy'}

\author{
Hans Pruijt and Pascal Dérogée
}

After having investigated attitudes towards risks and the willingness to share risks in the previous chapters, we now turn to the actual practices of risk sharing and risk management. Perceiving risks as social risks and being willing to share social risks is one thing, being able to transform these perceptions and willingness into actual policies is another. This is dependent, among other things, on the institutional environment in which these policies have to be developed and is dependent upon the organisations firms and administrative agencies - in which they are to be implemented. We will investigate these processes in the following chapters.

We start our investigation of the actual practices of risk sharing and of risk management in this chapter by analysing the introduction of the idea of increased job security through enhanced employability in the Netherlands. We will look into the development of the policy discourse, the introduction of employability in collective labour agreements and the practice of employability policies in firms. Employability is introduced as a means to increase the job security of workers by investing in their capabilities instead of providing them with social security protection. However, this investment strategy creates collective action problems: Why invest in workers and consequently run the risk that they will leave the firm and that another employer reaps the rewards of this investment? What we learn in this chapter is that the 'old' institutions of the social security state - for which employability is often presented as an alternative - have fulfilled an important role in making the introduction of employability a relative success, because these 'old' institutions have helped overcome the collective action problems presented by the new strategy of enhancing employability. 
The risk of losing one's capability to secure attractive employment, or to maintain sufficient 'employability', has gained more attention during the last decade. In the debate on the transformation of the welfare state the loss of the capability to secure employment is seen as one of the "new social risks" that result from the transition to a post-industrial society (Taylor-Gooby 2004). When it comes to managing this risk, it is now assumed, at least in the Netherlands, that enhanced employability is the new job security - in short: employacurity. Employability offers a means for risk management in the Dutch welfare state. In this chapter, we take a closer look at the use of employability as a means of risk management. The guiding question is: how realistic is the idea of employacurity and how and to what extent are strategies of securing or enhancing employability implemented in collective labour agreements and in firms?

After some conceptual clarification, we investigate the original core of the employability discourse, focusing on its built-in attractions. This discourse is the product of American management gurus who present the employment system of Silicon Valley as a model that, in their view, can be generalised to society as a whole. Accepted theory, however, suggests that collective action problems are associated with employability, which detracts from the realism of the gurus' visions. We attempt to shed light on the extent to which collective action problems hamper the strategy of increasing job security by enhancing employability and on the mechanisms that may alleviate such collective action problems. We do this by examining the paradoxical reception of the frame in the Netherlands. It is paradoxical, since it took root in a context that is the opposite of its context of origin: in contrast to Silicon Valley, the Dutch employment relations system is firmly based on the norm of job security. Empirically, we base our argument on an analysis of agenda-setting documents produced by the main Dutch trade union confederation and the main Dutch employers' association, a database of collective labour agreements and a case study of a Dutch organisation that exhibits a high level of activity regarding employability.

The concept of employability, roughly meaning the capability to be employed, often comes across as fuzzy, slippery, complex and variegated. Therefore, some conceptual clarification is necessary. In the conceptual literature we see several attempts to create order by constructing typologies. Tamkin and Hillage (1999), who reviewed the literature and interviewed experts, distinguish five basic strands of employability. Gazier 
(1999) distinguishes seven main concepts of employability. There is, however, no need for an explosion of complexity here. In the conceptual literature, some authors go beyond differentiating the concept and look for the one leading interpretation. Gazier notes, for example, that there is a development in the way in which employability tends to be seen, and suggests, as the most up to date definition of employability, that it is what makes 'each worker a more aware and a more independent organizer of the succession of activities and commitments that, combined, constitute his/ her working life' (2001: 23). Schmid (2006), in the same vein, stresses that autonomy is an important component of employability. In general terms, the integrative definitions of employability amount to empowerment in matters of career development. We take the above as a starting point and we will analyse employability from the perspective of empowerment.

\section{$2 \quad$ Framing employability}

The concept of employability and its acceptance as a form of risk management can be traced back to American management discourse. In this discourse, employability and creative destruction are linked in an attractive frame. The structure of the discourse is the following. First, a process of creative destruction is observed, i.e. the disappearance of old economic structures which frees (financial and human) resources for new enterprise endeavours (cf. Schumpeter 1942), causes social problems in the sense that employment security is decreased substantially. Adapting an organisation to creative destruction thus entails the disappearance of job security (Kanter 1991). To thrive in an era of creative destruction, companies need to be nimble. This involves moving into territories where the existing workforce may not be able to follow. Therefore, employers can no longer promise job security; job security is obsolete (Ghoshal et al. 1999: 15; Herriot and Pemberton 1996) and long-term secure employment is a thing of the past (cf. Kanter 1993). Employability is then launched as a concept that promises, when wholeheartedly applied, to help solve or alleviate the problem of lost job security. They argue that if workers are employable, then they are protected against risks such as the loss of employment. Gaspersz and Ott (1996), inspired by Kanter, announced the death of job security in the Netherlands, notwithstanding their note that, at the time of writing, people were clinging to their jobs more than ever before in the Netherlands. The number of people switching employment in one year had declined from 15 per cent in 1990 to just eight per cent in 
1994. The solution to the problem of creative destruction is enhanced employability. Kanter (1989) lifted the term employability from the context in which it was normally used, that of people without work (cf. Orr 1973), and applied it to employees.

Right from the beginning, employability was seen as a form of empowerment. Kanter describes how employees 'create their own opportunities' in organisations of which 'entrepreneurialism' is a defining characteristic (1993: 305). Littleton et al. (2000) speak of 'boundaryless' careers that develop in a context structured by the actions of employees. Savickas sees individuals as 'managers of their own worklives'. He maintains that the new pattern is best understood from a constructivist perspective because such a perspective concentrates on 'self-conceiving, self-organizing processes' (Savickas 2000: 59). Waterman and colleagues approvingly quote managers of companies that have employability policies in place as saying: 'we became convinced that we had a responsibility to put employees back in control of their lives' and 'the new covenant is about empowering people so they have job choices when circumstances change' (1994: 8889). These authors also tell us that companies on the cutting edge 'give employees the power to assess, hone, redirect, and expand their skills so that they can stay competitive in the job market' (1994: 88). Conversely, authors tend to describe what they see as the disappearing pattern of employment as the opposite of freedom. Littleton et al. (2000) depict the development of a working life in the old pattern as 'pre-ordained' and the careers as 'bounded' i.e. prescribed by organisational structures. Ghoshal et al. (1999) suggest that the new type of human resource management puts an end to the dependent position of employees.

A second characteristic of enhanced employability, as prescribed against the woes of creative destruction, is that it is something that can be created. The idea is that employability is amenable to substantial enhancement through investment (Kanter 1993). Possible assets to invest in are: awareness of marketable skills and talents, self-presentation efficacy, actual levels of skill, knowledge and experience (Ghoshal et al. 1999). In addition to this, some theorists emphasise that cultivating a personal network is key to a successful 'boundaryless' career, because of the value of network ties and the learning opportunities they can provide (Arthur and Rousseau 1995). Kanter suggests that a viable strategy for organisations is to provide 'ample learning opportunities, from formal training to lunchtime seminars - the equivalent of a month a year', 'challenging jobs and rotating assignments that allow growth in skills' and 'three months educational sabbaticals or external internships every five years', as well 
as to 'retrain employees as soon as jobs become obsolete' and to 'find job opportunities in the organization's network of suppliers, customers, and venture partners' (1991: 9). Waterman et al. (1994: 89) add that organisations can make employees aware of their 'skills, interests, values, and temperaments'. They mention benchmarking, self assessment and establishing a career centre that offers testing, counselling, seminars and information about jobs in and outside the organisation as suitable instruments.

There are several other features of this line of thinking that make it attractive. One of its attractions is that the prescription of enhanced employability is universally applicable; there is little contemplation about what works where. Beginning with Kanter (1991), advocates of stepped-up investment in employability seem tacitly to assume that it will benefit anyone, and that this will be so from school-leaving age to retirement age. Statements such as 'from full employment to full employability' and 'from lifetime employment to lifetime employability' also suggest universal applicability.

A further attraction of this type of thinking is that a win-win situation for all parties is painted, de-emphasising or bridging contradictions. In their analysis of the employability discourse, Hallier and Butts (1999:6) see it as a rhetoric aimed at defusing intensifying antagonisms by suggesting an area of parallel interests between employers and employees. They also see it as a legitimisation strategy in regard to public opinion: it shows companies making investments in people that benefit the economy as a whole.

The present discourse seems to mask a shift in power to the advantage of employers. Psychological contract theory plays a role in this. A psychological contract is a set of expectations that the employer and employee have of each other. The theory is that the 'old psychological contract', in which the employer was expected to try and maintain a permanent employment relationship with the employee in exchange for loyalty and performance, is giving way to a 'new psychological contract' where the above no longer holds. The use of the word 'contract' here suggests that it is somehow binding for both parties in the employment relationship, i.e. that the employee is not completely at the whim of the employer. In the new psychological contract, the expectation is that employers will invest in their employees' employability, in exchange for employee commitment (Ellig 1998). Commitment, in this context, is thinking of opportunities instead of entitlements (Ellig 1998) and thriving in a 'performance culture' (Rajan 1997). Anderson and Schalk tell us that commitment entails 'intrapreneurship, innovation, enacting changes to improve performance, excellent performance' whereas previously 'loyalty, attendance, satisfactory performance, compliance with authority' sufficed (1998: 642). 
Finally, the idea of employability is associated with tremendous business success and prestigious dynamism. Credibility is derived from an empirical basis: in this case, Silicon Valley. In the 1990s, Silicon Valley was, like Japan in the 1980s, in terms of economic dynamics, the most widely respected territory on the planet. Kanter's heroes were the 'roving engineers' who created Silicon Valley. The same people provided the prototype for Littleton's (2000) 'boundaryless' careers. Waterman et al. (1994) give examples of employability policies in renowned Silicon Valley companies, based on their own experience: Judith Waterman and Betsy Collard were involved in Silicon Valley-based organisations that provided career counselling. To summarise: management gurus have created a distinctive, consistent frame that promotes continuous investment in employees' employability as the key to long-term security. It is built on an empirical reference, Silicon Valley, and on a set of beliefs centred on learning, networking and win-win relationships between employers and employees.

After surveying these characteristics, it seems legitimate to ask what was new here. After all, that being attractive to employers is a source of security, and that learning opportunities are valuable can hardly count as spectacular insights. What was new, however, was the connecting of a specific conception of employability, seen as the empowerment of employees, and creative destruction, and packaging this in a voluntaristic discourse, framed in terms of a new psychological contract.

\section{Potential wishful thinking and a collective action problem}

Following the theory of collective action (Olson 1965), the employacurity model presents a serious collective action problem. This is because it involves creating a skills formation system that can be seen as a public good, which creates free rider problems: for an employer, investing in his/her employees is less rational than poaching trained staff from competitors (Crouch 2006). These free rider problems will undermine the strategy of employacurity. The management literature exhibits little awareness of this. It promotes investing in employability as a tool for retaining valued employees (Ghoshal et al. 1999: 17; Vries et al. 2001: 1193), and as a way for a corporation to establish a reputation as an interesting potential employer. Ghoshal et al. (1999: 16) mention the example of Motorola with its 'Motorola University'. The theory of the new psychological contract also hints at a private good that the employer can gain when investing in employees' employability: a non-sticky type of employee commitment. 
Several authors suggest that enlightened entrepreneurship can play a role in a decision to invest in employability. Ghoshal et al. (1999) assert that top managers who want to create more value beyond shareholder value can do this by investing in employees. It also unleashes innovation, cooperation and the sharing of knowledge from the boundaries formed by pure self-interest as an organisational guiding principle (Ghoshal et al. 1999). Kanter (1993) speaks of creating 'social value'.

How valid is the claim that Silicon Valley's (probably stylised) model can be generalised to society as a whole? The Silicon Valley model exhibits specific characteristics that are often cited as being able to help solve or alleviate the collective good dilemma. One of these is Silicon Valley's nature as an industrial district. Porter (1998: 78) argues that in industrial districts, defined as 'geographic concentrations of interconnected companies and institutions in a particular field', the ties between companies make the potential for collective benefits more easily recognised. Therefore, private investments in public goods, such as training programmes, are more likely to happen in a tightly-knit industrial district than in areas where at best, arm's length market relationships between organisations exist. In addition to this, one may expect that networks also facilitate a flow of people across opportunities (Kanter 1995).

Another factor which may help solve or alleviate the collective good dilemma is the knowledge-intensity of the work being carried out. Crouch (2006) mentions the knowledge-intensity of the work as a factor contributing to private investment in a public good skills formation system. This applies particularly to the Silicon Valley case because in the innovative ICT industry, getting the work done and creating a learning environment are two sides of the same coin. Looking at the question of possible generalisation of the Silicon Valley employment model, Kanter (1995) realises that generalisation would not be straightforward. She concludes that collective action would be necessary, specifically in the form of providing supporting networks between firms.

\section{The paradoxical rise of employacurity in the Netherlands}

In the United States, following the 2000 dot-com bust, the appeal of employacurity faded. Instead, the general prospect became just heightened mobility combined with insecurity (Katz and Wheeler 2004). In contrast to this, in the Netherlands, the vision of employacurity not only became popular in the late 199os, but its star has continued to rise. We will argue 
that there is a paradox: although employacurity aims to generalise an employment system that is the total opposite of job security, it is most productive in an employment system (the Dutch system) based on the norm of job security.

The rise of employacurity in the Netherlands began when the Dutch discovered the untranslatable word 'employability'. This happened in the early 1990 os when a leading consultancy firm, Berenschot, began promoting the concept to human resource management professionals and labour market specialists. The word 'employability' appeared for the first time on a Dutch newspaper page in $1993^{2}$ when Joep Bolweg, consultant and managing director at Berenschot Social Management Group, voiced his opinion about standardised career tracks: 'Extremely dangerous, because they create false expectations. The organization of the near future is unknown, as are the positions in it that have to be filled. There is no resort other than increasing the versatility and employability of the employees' (Meijnen 1993: 23). In response to a query in 2009 regarding where he had first come across the term employability, Bolweg explained that it was in the US (oral communication).

Heleen Mes (1995), also from Berenschot, published the first Dutch article on employability, and in the section that explains the concept of employability, the author quotes sources such as Robert Saldich, president of Raychem, a Silicon Valley company, and management guru Robert Waterman. The first Dutch book on employability was published in 1996 (Gaspersz and Ott 1996). It quotes and builds on Kanter's ideas. In short, the two seminal Dutch texts on employability are exclusively based on US sources.

The next phase in the diffusion process in the Netherlands involved the adoption of the concept by key Dutch labour market and economic institutions. When explaining employability, policy documents from this phase refer to the two seminal Dutch texts mentioned above. In late 1996, the Dutch Labour Foundation, the joint institution of employers' associations and unions that sets the agenda for collective bargaining, produced a policy document on employee training (Stichting van de Arbeid 1996). Referring to the Gaspersz and Ott (1996) book, the authors adopted the perspective of 'employability', noting there is not a good Dutch equivalent for the term. In 1997, the Ministry of Economic Affairs organised an 'Employability Conference', where Prime Minister Wim Kok spoke about the topic. In the conference documents, the source referred to the meaning of employability is again the Gaspersz and Ott book (Andriesse and Planken 1997). The Dutch Socio-Economic Council and the Central Planning Bu- 
reau followed with policy documents that exhibit the same pattern (SER 1998; CPB 1999).

References to employability recommendations made by international institutions only occur in Dutch policy documents post 2001, that is, only after the employability discourse and policy were firmly established in the Netherlands. Here, the context of references to documents from international bodies is one of justification rather than discovery. One example is a 2002 Dutch Labour Foundation report that focuses on EU recommendations (Stichting van de Arbeid 2002). This report notes that the Labour Foundation had already been working on the issue of employability for the past six years, and that the EU recommendations were, to an extent, based on the Dutch experience. In short, during the phase in which employability policy became established, the policy documents of key Dutch institutions exclusively refer to a small, Dutch base of seminal literature. This seminal literature, in turn, is based on what we have called American guru thinking, thinking that has an empirical background in Silicon Valley.

More recently, the concept of employability has started to inform the debate about the future of the welfare state in the Netherlands. Thinkers on this subject tend to emphasise investment in employability rather than consumption, with the popular metaphor used of the welfare state moving from a 'safety net' to a 'trampoline' (Leijnse et al. 2002). In addition, in 2007, the concept of employability was incorporated into the coalition agreement that formed the basis of the new Dutch government (Balkenende IV).

\section{Trade unions and employers' associations}

In the Netherlands, both employers' representatives and union leaders tend to be adamant about employability. We can take this as a consensus, however with one qualification: when unions and employers' associations speak about employability, they are not entirely speaking about the same thing. During the 1998 collective bargaining round, it became apparent that employers and the trade unions did not agree on how to translate the word 'employability'.

Dutch union representatives chose 'weerbaarheid' meaning empowerment (Veenis 1998), while employers thought of 'inzetbaarheid, mobiliteit, flexibiliteit', which means availability or usability, mobility, flexibility. Defining employability in this way, employers stressed traits they felt were desirable in employees. ${ }^{3}$ The differing ways in which employability has 
been interpreted in the Netherlands have persisted throughout the development of employability policy. We analysed a database containing programmatic texts produced by the trade union confederation FNV (Federatie Nederlandse Vakbeweging) and the employer's association VNO/ NCW (Verbond Nederlandse Ondernemingen/Nederlands Christelijk Werkgeversverbond). ${ }^{4}$ Our research strategy consisted of examining every document for sections containing the word 'employability', and then determining how the authors had defined employability in each case. The results are summarised in Table 1.

Table 1 Definitions of "employability" in programmatic texts produced by the trade union confederation FNV and the employers' association VNO/NCW

\begin{tabular}{lll}
\hline & FNV & VNO/NCW \\
\hline 1996 & term does not occur & term does not occur \\
\hline 1997 & $\begin{array}{l}\text { no definition, keeps the term } \\
\text { at arm's length by putting it in } \\
\text { inverted commas }\end{array}$ & $\begin{array}{l}\text { qualifications, training beyond actual } \\
\text { function requirements, usability, physical } \\
\text { and intellectual mobility, flexible attitude }\end{array}$ \\
\hline 1998 & & $\begin{array}{l}\text { usability, physical and intellectual mobility, } \\
\text { flexible attitude }\end{array}$ \\
\hline 2000 & associated with training & $\begin{array}{l}\text { usability, physical and intellectual mobility, } \\
\text { flexible attitude }\end{array}$ \\
\hline 2001 & & $\begin{array}{l}\text { usability, physical and intellectual mobility, } \\
\text { flexible attitude }\end{array}$ \\
\hline 2002 & & $\begin{array}{l}\text { usability, physical and intellectual mobility, } \\
\text { flexible attitude }\end{array}$ \\
\hline 2003 & & $\begin{array}{l}\text { usability, physical and intellectual mobility, } \\
\text { flexible attitude }\end{array}$ \\
\hline 2004 & associated with training & $\begin{array}{l}\text { usability, physical and intellectual mobility, } \\
\text { flexible attitude }\end{array}$ \\
\hline 2005 & & $\begin{array}{l}\text { usability, physical and intellectual mobility, } \\
\text { flexible attitude }\end{array}$ \\
\hline 2006 & "employability is the right to & $\begin{array}{l}\text { usability, physical and intellectual mobility, } \\
\text { flexible attitude }\end{array}$ \\
\hline
\end{tabular}

The concept of employability became evident in Dutch industrial relations in 1997. At first, the unions voiced reservations about the term. Eventually, however, they began associating it with training, which led to their 
embracing of the employability concept as a form of employee empowerment. In contrast, employers began using a definition that included usability, mobility and flexibility and have kept to this. The inclusion of the terms usability, mobility and flexibility in the definition of employability favoured by the employers is crucial. It creates an image of employability that can help employers overcome the collective good dilemma that investment in employability entails. This is due to the promise of a private advantage of employability investments, i.e. that it will make it easier for employers to move their employees around.

The Dutch employment relations system is based on an implicit norm of job security, i.e. the idea that employees must be provided with a secure job, leaving employers with a craving for more flexibility. The inclusion of usability, mobility and flexibility in the employers' definition of employability speaks to their desire for increased flexibility, producing a discourse that might lower barriers preventing investment in the public good. Moreover, and as a result of Dutch central coordination of collective bargaining through bipartite institutions, this discourse is visible in collective labour agreements as well.

It is important to realise that employers' inclusion of usability, mobility and flexibility in their definition of employability only has consequences at the level of ideology. Increased usability, mobility and flexibility are aims, not assets that lend themselves to direct investment. At the practical level, assets that do lend themselves to direct investments are skills, knowledge, insights and contacts. There are no indications that Dutch employers and unions feel differently about this. The central part of our argument here can be summarised as follows: the inclusion and confusion of usability, mobility and flexibility promises a private advantage to employers - a way around the collective action dilemma. The proposition of such a private advantage is possible because Dutch employers crave flexibility, and this, in turn, is because the Dutch system is based on the norm of job security.

\section{Collective labour agreements}

Collective labour agreements can also help solve the collective action dilemma, provided that they cover a sufficient number of employers in a given industry. In the Netherlands, this coverage is generated in part by law, which makes industry-wide enforcement of collective labour agreements possible (CPB 1999). In this section, we present an analysis 
of collective labour agreements demonstrating a relationship between investments in employability and items that regulate and make flexible employment possible. The existence of this relationship suggests a quid pro quo. It is easier to reach an agreement on investments in employability, in this case training that is not job-related or function-specific and the creation of personal development plans, when simultaneously catering to the employers' craving for flexibility. Again, this development signals a mechanism that can make employacurity productive in a system based on the norm of job security. We will cover the analysis in some detail below.

Our analysis is based on the FNV Ducadam database (see Chapter six in this volume for more information). It covers nearly all collective labour agreements concluded in the Netherlands from 1995 onwards and spans all sectors of the economy. Collective labour agreements are coded on 650 main variables (Schreuder and Tijdens 2004). We used the data from 1995 up to $2003 . .^{5}$ The total number of cases in our analysis is 2162 .

When it comes to finding indicators on employability investments, the subject of training presents something of a problem. We can picture training in a continuum. At one extreme, training is completely job and company specific, at the other extreme of the continuum there is general, non job-related training. In between these two extremes we find training that is multifunctional. Such training can help someone's performance on the job, and, at the same time, boost the employee's employability. We would not regard job and company-specific training as an investment in employability. Conversely, it is straightforward to see training that is general and not job-related as an investment in employability. In short, taking all training as investment in employability would lead to an overestimation. Thus, because we prefer to err on the safe side, we decided to restrict ourselves to the extreme of general and non job-related training. Luckily, the designers of the database created an indicator for non job-related training, which we used. An additional advantage of taking only clearly non job-related training into account is that it provides a focus on investments that are strictly aimed towards the public good of an employable workforce, which is at the heart of our argument.

Apart from this indicator, we included an indicator measuring the occurrence of personal development plans in collective bargaining. Again, we see this indicator as unambiguously investing in employability as a public good. Together, both indicators make up a dichotomous variable for employability policy. It has the value of one if job-unrelated training 
and/or personal development plans are included in the collective labour agreement $(26.0 \%){ }^{6}$

Suitable indicators for flexibility clauses are also present in the dataset. There are two indicators that correspond to the concept of numerical flexibility, i.e. management's ability to vary the number of employees working for the organisation. One of these records whether the collective labour agreement makes it possible to conclude fixed-term employment contracts. Another indicator captures clauses that make it possible to offer zero-hour contracts, i.e. contracts that entail that the work week counts a variable number of hours, which may be zero. Using these indicators, we created a new variable for numerical flexibility. Its score is zero if none of the items were found within the collective labour agreement (50.6\%) and one if either one or both of the items were found within the collective labour agreement (49.4\%). ${ }^{7}$

A cross tabulation of employability and flexibility within collective labour demonstrates a possible relationship between the two (Table 2). If no arrangements are made about investments in employability, the majority of collective labour agreements will not contain arrangements about flexible labour contracts $(57.8 \%)$. In contrast, if there are employability arrangements within the collective labour agreement, the majority contain flexible employment contract arrangements (69.8\%). We found a correlation between the two variables of .24, significant at the $\mathrm{p}<.05$ level.

Table 2 Cross tabulation employability with numerical flexibility in collective labour agreements

\begin{tabular}{llll}
\hline $\begin{array}{l}\text { Collective Labour } \\
\text { Agreements 1995-2003 }\end{array}$ & $\begin{array}{l}\text { No clauses on numerical } \\
\text { flexibility }\end{array}$ & $\begin{array}{l}\text { Clauses on } \\
\text { numerical } \\
\text { flexibility }\end{array}$ & Total \\
\hline $\begin{array}{l}\text { No clear employability } \\
\text { policy }\end{array}$ & 924 & 675 & 1599 \\
Row \% & $(57.8 \%)$ & $(42.2 \%)$ & $(100.0 \%)$ \\
\hline $\begin{array}{l}\text { Clear employability } \\
\text { policy }\end{array}$ & 170 & 393 & 563 \\
Row \% & $(30.2 \%)$ & $(69.8 \%)$ & $(100.0 \%)$ \\
\hline $\begin{array}{l}\text { Total } \\
\text { Row \% }\end{array}$ & 1094 & 1068 & 2162 \\
\hline
\end{tabular}


The data cover the years 1995 through 2003. The proportion of collective labour agreements with clauses on employability investments grew over time, from 5.7 per cent in 1995 to 31.4 per cent in 2003. The proportion of collective labour agreements with clauses on numerical flexibility also grew during this period. The increase in these variables across time introduces a possible problem of spurious relationships. It could be that both factors have increased across time, but independently. A way to account for this possibility is to perform a linear regression analysis in which time is included as an independent variable. When we do so, our analysis shows a significant effect of flexible labour contracts remains (Table 3).

Table 3 Employability predicted on the basis of flexibility, controlled for changes across time

\begin{tabular}{|c|c|}
\hline $\begin{array}{l}\text { Dependent variable: } \\
\text { Employability within collective labour } \\
\text { agreement }\end{array}$ & $\begin{array}{l}\text { Standardised coefficients } \\
\text { Beta }\end{array}$ \\
\hline $\begin{array}{l}\text { Independent variable: } \\
\text { Time (measured as year for collective labour } \\
\text { agreement years 1995-2003) }\end{array}$ & $0.094^{* * *}$ \\
\hline $\begin{array}{l}\text { Independent variable: } \\
\text { Flexible employment contracts within } \\
\text { collective labour agreement }\end{array}$ & $0.212^{* * *}$ \\
\hline $\mathrm{R} 2$ & 0.059 \\
\hline $\mathrm{N}$ & 2162 \\
\hline
\end{tabular}

To summarise: the regression analysis shows that collective labour agreements containing clauses on employability investments are also more likely to have arrangements that focus on numerical flexibility, an indication that employability investments are traded for flexibility arrangements. The small percentage of the total variance explained is inherent to the method being used. It also reflects that contingent factors play a large role. There are indications that employability, apart from its intrinsic value, is a convenient bargaining chip in the final phase of wage negotiations. Joep Bolweg provided the following example. Say, for example, that the unions ask for a three per cent wage increase, while the employer is reluctant to agree. It is not unlikely that the parties will agree to a two per cent wage increase and one per cent allocated for investment in employability. Unions can claim the success of obtaining a three per cent increase for employees, while the employer maintains control over 
one-third of the financial space for wage increases. Once such an agreement is reached, both sides tend to extol the virtues of employability. As Bulmahn and Kräkel (2002) show, in cases where jobs are associated with high risks, employers prefer to have over-educated workers because they are more capable of taking appropriate measures and improvising if necessary, when something goes wrong.

\section{Case study of a large bank}

In this section we will explore how employacurity guides actions at the level of the organisation. To do this, we present a case study of a large bank based in the Netherlands, ING, which has considerably enhanced its employability policy. Brakenhoff, Dusschooten et al. (2008) presented ING as a best practice case in terms of social innovation. The sources used here are the employability sections of a succession of six collective labour agreements at ING covering the time period 2000-2010, and interviews with protagonists, the top human resources manager for ING operations in the Netherlands consisting of 28 , ooo employees and the key trade union negotiator. Specifically, we were interested in how the collective action problem was managed.

ING employability arrangements consist of the following aspects: in every part of the organisation, employability consultants provide coaching to employees, employees have to make personal development plans that are discussed and evaluated on a yearly basis and job rotation exists to enhance experience. There is a website that offers employability and development tests and an 'e-coach' (Bosveld 2009). In one year this website received 77,000 hits and users downloaded 50,000 test reports. Employability arrangements also come into play when ING is faced with downsizing. For example, if a reduction of 100 jobs is planned, an entire department of upwards of 1000 employees is declared to be 'preventatively mobile' and a social plan is created to train and coach employees potentially at risk of losing their job. In short, everyone's job within the chosen department is theoretically at risk, meaning that the facilities provided by the social plan, such as training and coaching, are open to all. The idea is that by taking a broad approach, employees will see investment in employability as a preventative measure, rather than as a way of softening the blow when downsizing.

ING earmarks ten million euros annually for investments in employability not related to the work that employees are doing or are planned to 
be doing in the future. This is on top of the employability arrangements already in place. Based on this arrangement, an individual employee can spend up to 1200 euros over the course of three years on activities, in particular training, as long as they are related to work in general and to employee development. Part-time employees are also entitled to 1200 euros of this arrangement, regardless of the amount of their working hours. Willem Daalder, the top human resource manager of the Dutch part of ING sees the 1200 euro plan as a 'means to create a shift in mindset' (interview). The arrangement was modelled on an arrangement used internally by trade union FNV Bondgenoten. A union official from FNV Bondgenoten, Fred Polhout, confirmed this, and expressed that it was important to him that he knew the 1200 euro plan could be implemented successfully, because 'otherwise you are organising your own defeat' (interview).

Essential to this scheme, as implemented by ING, is that employees take the initiative. They start by entering their proposals on-line. A special team evaluates the proposals; evaluation is swift and without going into details. Review teams consist of two people: a second level manager and the HR manager of the business unit. The HR manager especially has little time to spend on each application, since the unit for which he or she is responsible, retail for example, may comprise as many as $12,000 \mathrm{em}-$ ployees. The review teams review applications via computer only. If their assessments differ, they then discuss the case.

One valid reason for turning down a proposal is that it is too closely related to the actual work an employee does, and therefore within the realm of the budget for regular training. The employee's supervisor has no say in the spending of the 1200 euros for employability. The activities are undertaken in the employee's own time. A communications campaign 'me and my employability' supports the programme. It includes a magazine that portrays employees who worked on their development. It shows, for example, a call centre agent who learned truck driving and aspires to become a truck driver. There are on-line 9o-second movies in which employees talk about what they are going to do in the 1200 euro scheme and their motivation for it. A set of posters depicts employees and their various viewpoints. Examples include: 'I want to get more out of my job', put forward by a support worker, who is 'investigating what else is possible.' 'For years I have been wanting to do something else', stated by a commercial clerk, 'soon to be the owner of a hotel for dogs.' 'For the moment I want nothing', which is the reaction of a product manager who wants 'to continue with this employment for some time.' 'I don't want to lose my people', a statement made by a manager (Brakenhoff, Dusschooten et al. 2008: 173-175). 
In 2008, there were 4,900 applications, spread among all levels of the organisation, of which 72 per cent were accepted. The top human resource manager has found some resistance among managers, to which he tends to react by telling them that if they see good people leave after taking advantage of all the opportunities for development, capable replacements are bound to turn up: 'In a way, it is the psychological contract' (interview). The Dutch Tax Administration is also a source of some resistance, due to a tendency for it in some cases to see the employability money as taxable income.

What made this enhancement of employability policy possible? There were several ingredients that came together. One is the clear vision of the protagonists. The HR manager views employability as empowerment: 'Make sure that people become resilient, that they can take responsibility. This is much better than when someone cares for them. Thus, what I am trying to do is to make people take responsibility, to be in control of their own career.' He takes care to avoid confusion with mobility: 'Often, what you see is that employability is synonymous to mobility. Here, that is absolutely not the case. Employability may lead to mobility, but it is not the same' (interview). The FNV trade union negotiator: 'Employability is the way to keep people in employment longer. Give people opportunities. Of course, some people will take care of themselves and other people will need help. If you invest as much as possible, some people will see the light. We are trying to do this within ING, with the employability budget, for which the FNV has made a big effort' (interview).

Then, there was the window of opportunity that opened in 2006 with the bargaining about the Social Plan, i.e. a plan that stipulates how layoffs will be handled. At ING, large reorganisations, plus outsourcing, loomed on the horizon, and negotiations took a full year. This prompted a desire to stop managing the consequences of change exclusively at the 'back end', and instead also do something at the 'front end'. The goal was to avoid sending employees into unemployment by facilitating transitions from 'work to work'. Thus, this window of opportunity was opened in a quest for flexibility without violating the norm of job security.

The same holds true in the justification process for the 10 million per year expenditure for the employability budget. This justification process involves reporting inter-divisional mobility and lay-off costs as key performance indicators. These are both indicators of flexibility. Again, we see a private payoff for the organisation in conjunction with investment in the collective good. This private payoff, flexibility, is valuable in the context of an employment system that is based on the norm of job security. 


\section{Concluding notes}

The fact that the introduction of the strategy of increasing job security by enhancing employability - employacurity - has been a success in the Netherlands can be viewed as an instance of institutional complementarity. Institutional complementarity exists in 'situations in which the functionality of an institutional form is conditioned by other institutions' (Höpner 1995: 331.) In employacurity, the norm of job security conditions the functionality of policies for investment in employability. This complementarity is unintended, but, as far as institutional complementarities go, this seems to be more the rule than the exception (cf. Crouch et al. 2005: 365).

The Dutch employment system solves the public good problem related to investments in enhanced employability in several ways. Foremost is that it creates the perception among employers that enhanced employability, apart from being a public good, entails private benefits for employers, in the form of flexibility.

Additionally, the coordinated nature of the collective bargaining process, in which the bipartite Dutch Labour Foundation sets the agenda, creates institutional pressure and coordinated wage setting helps limit the poaching of employees. These factors operate regardless of whether collective labour agreements cover entire industries or, in the case of ING, just one company. Dutch law makes industry-wide enforcement of collective labour agreements possible, cutting out free-rider behaviour. The fact that the strategy of employacurity is made possible by Dutch corporatist institutions not only results from the bargaining system but also from the fact that 'sector funds' exist, which engage in a variety of activities, of which training is the most notable. The main source of income of these sector funds is a percentage of the wage sum contributed by the employers in a particular sector, as agreed to in collective bargaining. Generally, employers have no option but to pay the contribution: 92 per cent of Dutch sector funds have their funding written into a collective labour agreement and 79 per cent of the collective labour agreements are enforced industry-wide.

Finally, employacurity, paradoxically, seems productive when it builds on a system based on the norm of job security. In thinking of a new scenario for managing collective risks it may be straightforward to accord an important role to firms as investors in employability. However, there is no reason for employers to take on this responsibility. Employers in the Netherlands did develop an interest in employability - pushed in this direction by the corporatist bargaining system - because employers were eager to remedy a perceived lack of labour flexibility. 


\section{Notes}

1 This chapter is derived form our article "Employability and job security, friends or foes? The paradoxical reception of employacurity in the Netherlands", Socio-economic Review, 2010, 8-3: 437-460, Oxford University Press and The Society for the Advancement of Socio-Economics. We are grateful to Mara Yerkes for granting access to the database of programmatic documents, and for introducing us to the DUCADAM database. Sander Quak provided vital information. We thank our fellow members of the project team "Work and Social Security", and three anonymous reviewers for their feedback on an earlier version of this paper.

2 This was determined through a search in the Lexis-Nexis database.

3 We traced the employer-favoured definition back to the Berenschot consultancy firm. In his 1993 interview, its managing director/consultant Joep Bolweg defined employability as 'willingness to take training, usability, geographical mobility and positive attitude towards change' (Meijnen 1993: 23). When Heleen Mes (1995), from the same consultancy firm, elaborated on this definition in a Dutch management journal, she described the origin of the term employability as a combination of the words employment and adaptability. According to Gaspersz and Ott (1996), however, this is an etymological myth.

4 This database was created by Mara Yerkes and Marco Veenstra. See Yerkes 2011 for more information.

5 The reason for this restriction is that after 2003, coding of employability indicators is inconsistent. The complete dataset can be downloaded from the website: http: //www1.fee.uva.nl/aias/Ducadam/.

6 To illustrate, an example of a clause in a Dutch collective labour agreement that underpins investments in employability reads:

'Both the employer and the employee have their own responsibilities in relation to development efforts. The responsibilities of both parties are expressed in development policy targets:

- to keep the knowledge of the employees up-to-date, as a means of improving their preparation for their job or to enhance their multi-functionality.

- in the long run, employees should be able to move to a different job.

- there will be additional training efforts for employees who are at a risk of becoming under-trained in their job. There will also be extra training efforts aimed at employees who are sufficiently qualified but who are no longer used to learning.' (Collective labour agreement of Croda, formerly Uniquema 2008: 60).

7 An example of a Dutch collective labour agreement clause that entails numerical flexibility reads: 'The work schedule depends on the supply of work 
for on-call workers. It will be distributed one week in advance' (collective labour agreement of ABP Loyalis 2006: 14.).

\section{References}

Anderson, Neil and René Schalk 1998. "The psychological contract in retrospect and prospect", Journal of Organizational Behavior, 19: 637-647.

Andriesse, Freek G. and Ton Planken 1997. Employability: werken aan het vermogen om werk te krijgen en te houden / verslag employability congres, 8 oktober 1997, Den Haag: Ministerie van Economische Zaken.

Arthur, Michael B. and Denise M. Rousseau 1995. "Introduction: The boundaryless career as a new employment principle". Pp. 3-20 in The boundaryless career: a new employment principle for a new organizational era, edited by Michael B. Arthur, and Denise M. Rousseau, New York: Oxford University Press.

Auer, Peter 2006. "Protected mobility for employment and decent work: Labour market security in a globalized world", Journal of Industrial Relations, 48: 21-42.

Benford, Robert D. 20oo. "Framing Processes and Social Movements: An Overview and Assessment”, Annual review of sociology, 26: 611-639.

Bosveld, Karin 2009. "Digitale employability bij ING en Philips: 'Zorg dat als je baan omvalt, jij niet omvalt", $N S v P$-journaal, 5: issue 1, 2-3.

Brakenhoff, Michel, Caroline Dusschooten, Franciska Fleminger, Gerard Nieuwe Weme, Boke C. de Pater, Willem Spee and Lianne Vorstenbosch 2008. Kookboek Sociale Innovatie. Visies en Verhalen, Den Bosch: Stichting Greenfield Groep.

Bulmahn, Guido and Matthias Kräkel 2002. "Overeducated Workers an Insurance Device, Labour, 16: 383-402.

Burroni, Luigi and Maarten Keune 2009. Understanding the Multiple Sources of and Relationships Between Flexibility and Security: Towards a Governance Approach, Working Paper, European Trade Union Institute, Brussels, accessed at http: //aspen.fss.uu.nl/conference20o9/ docs/LuigiBurroni.rtf on October 28, 2009.

CPB 1999. Macro Economische Verkenningen. Speciale onderwerpen: employability, Den Haag: Centraal Planbureau.

Commissie Arbeidsparticipatie 2008. Naar een toekomst die werkt. Advies Commissie Arbeidsparticipatie, Rotterdam.

Crouch, Colin 2006. "Skill formation systems". Pp. 95-114 in The Oxford Handbook of Work and Organization, edited by Stephen Ackroyd, 
Rosemary Batt, Paul Thompson and Pamela Tolbert, Oxford: Oxford University Press.

Crouch, Colin, Wolfgang Streeck, Robert Boyer, Bruno Amable, Peter A. Hall and Gregory Jackson 2005. "Dialogue on 'Institutional complementarity' and political economy", Socio-Economic Review, 3: 359-382.

De Vries, S., Bob Grundemann and Tinka van Vuuren 2001. "Employability policy in Dutch organizations", International Journal of Human Resource Management, 12: 1193-1202.

Donker van Heel, Peter J. van Velden, J. Siegert, R. Groenendijk, M. de Kogel, and E. Sincer 2008. Hoe werken sectorfondsen? Rotterdam: ECORYS.

Ellig, Bruce R. 1998. "Employment and employability: foundation of the new social contract", Human Resource Management, 37: 173-175.

Gaspersz, Jeff and Marlies Ott 1996. Management van employability. Nieuwe kansen in arbeidsrelaties, Assen: Van Gorcum.

Gazier, Bernard 1999. "Employability: an evolutionary notion, an interactive concept. Definitions and trends". Pp. 37-71 in Employability: Concepts and Policies, edited by Bernard Gazier, Berlin: European Employment Observatory.

- 2001. "Employability - The Complexity of a Policy Notion". Pp. 3-23 in Employability: From Theory to Practice, edited by Patricia Weinert, Michele Baukens, Patrick Bollerot, Marina Pineschi-Gapenne and Ulrich Walwei, Somerset, NJ: Transaction Publishers.

Ghoshal, Sumantra, Christopher Bartlett, and Peter Moran 1999. "A new manifesto for management." Sloan Management Review, 40: 9-20.

Huczynski, Andrzej A. 1993. Management gurus: What makes them and how to become one, London: Routledge.

Hallier, Jerry and Stewart Butts 1999. "Employers' discovery of training: self-development, employability and the rhetoric of partnership", Employee Relations, 21: 80-95.

Herriot, Peter and Carole Pemberton 1996. "Contracting Careers”, Human Relations, 49: 757-790.

Höpner, Martin 1995. "What Connects Industrial Relations and Corporate Governance? Explaining Institutional Complementarity", SocioEconomic Review, 3: 331-358.

Kanter, Rosabeth Moss 1989. "The new managerial work”, Harvard Business Review, 67: 85-92.

- 1991. "Globalism/Localism: A New Human Resources Agenda", Harvard Business Review, 69: 9-10.

- 1993. "The View from the 1990s: How the Global Economy Is Reshaping Corporate Power and Careers. Afterword to the 1993 Edition". 
Pp. 289-328 in Men and Women of the Corporation, New York; Basic Books.

- 1995. "Nice Work If You Can Get It: The Software Industry as a Model for Tomorrow's Jobs. Some High-Tech Firms Are Redefining the Relationship between Employer and Employee", The American Prospect, 6, accessed at http: //www.prospect.org/cs/articles?article=nice_work_ if_you_can_get_it on October 28, 2009.

Katz, Harry C. and Hoyt N. Wheeler 2004. "Employment Relations in the United States of America". Pp. 67-9o in International and Comparative Employment Relations, edited by Greg J. Bamber, Russell D. Lansbury and Nick Wailes, London: Sage.

Leijnse, Frans, Kees Goudswaard, Janneke Plantenga and Jan Peter van den Toren 2002. Anders denken over zekerheid. Levenslopen, risico en verantwoordelijkheid, Den Haag: Ministerie van Sociale Zaken en Werkgelegenheid.

Littleton, Suellen M., Michael B. Arthur and Denise M. Rousseau 2000. "The future of boundaryless careers". Pp. 101-114 in The Future of Career, edited by Audrey Collin and Richard A. Young, Cambridge: Cambridge University Press.

Meijnen, Joop 1993, January 27. 'Ik repareer carrières voor mijn professie'; Vertrekbemiddeling is geen nieuw verschijnsel, maar personeelszaken maakt er steeds vaker gebruik van", NRC Handelsblad, Rotterdam, p. 23.

Mes, Heleen 1995. "Employability als nieuw medicijn”, Bedrijfskundig Vakblad, 7: 26-29.

Olson, Mancur 1965. The Logic of Collective Action. Public goods and the Theory of Groups. Cambridge, Massachusetts: Harvard University Press.

Orr, David. B. 1973. New directions in employability: reducing barriers to full employment, New York: Preager.

Porter, Michael E. 1998. "Clusters and the New Economics of Competition", Harvard Business Review, 76: 77-99.

Rajan, Amin 1997. "Employability in the finance sector: Rhetoric vs reality", Human Resource Management Journal, 7: 67-79.

Savickas, Mark L. 200o. "Renovating the psychology of careers for the twenty-first century". pp. 53-68 in The Future of Career, edited by Audrey Collin and Richard A. Young, Cambridge: Cambridge University Press.

Schmid, Günther 2006. "Social risk management through transitional labour markets", Socio-Economic Review, 4: 1-33.

Schreuder, Killian and Kea Tijdens 2004. Codeboek Ducadam Dataset: Een Statistisch Bestand Van De FNV Cao-Databank, Amsterdam: Amsterdam Institute for Advanced Labour Studies. 
Schumpeter, Joseph A. 1942. Capitalism, socialism E democracy, London: Routledge.

SER 1998. Sociaal-Economisch Beleid 1998-2002, Den Haag: Sociaal-Economische Raad.

Stichting van de Arbeid 2002. Actieprogramma voor het Leven Lang ontwikkelen van competenties en kwalificaties, Den Haag: Stichting van de Arbeid.

Stone, Nan 1991. "Does Business Have Any Business in Education?" Harvard Business Review, 69: 46-62.

Tamkin, Penny and Hillage, Jim 1999. Employability and Employers: the missing piece of the jigsaw, Brighton: IES.

Taylor-Gooby, Peter 2004. "New Risks and Social Change." Pp. 1-28 in New Risks, New Welfare. The Transformation of the European Welfare State, edited by Peter Taylor-Gooby, Oxford: Oxford University Press.

Veenis, Jeroen 1998. "Employability blijkt heet hangijzer bij CAO-overleg", HSI, accessed at http: //www.eurofound.europa.eu/eiro/1998/o1/ word/nl9801157nnl.doc on April 4, 2009.

Viebrock, Elke and Jochen Clasen 2009. "Flexicurity and welfare reform: a review", Socio-Economic Review, 7: 305-331.

Waterman, Robert H., Judith A. Waterman and Betsy A. Collard 1994. "Toward A Career-Resilient Workforce", Harvard Business Review, 72: 87-95.

Wilthagen, Ton and Frank Tros. 2004. "The Concept of Flexicurity: A New Approach to Regulating Employment and Labour Markets", Transfer: European Review of Labour and Research, 10: 166-186.

Yerkes, Mara 2011. Transforming the Dutch Welfare State: Social Risks and Corporatist Reform, Bristol: The Policy Press. 



\title{
6 Corporatism and the Mediation of Social Risks
}

\author{
The Interaction between Social Security and Collective Labour \\ Agreements $^{1}$
}

Mara Yerkes and Kea Tijdens

The level of protection against social risks that is organised in a welfare state is not only dependent upon the arrangements of the welfare state itself, but also, as we have seen in the previous chapter, on arrangements organised in firms or in collective bargaining. The previous chapter investigated the introduction of the idea of employability as a strategy to enhance job security and concluded that the collective bargaining process facilitated the introduction and relative success of this strategy in collective labour agreements and in the labour policies of firms. This was explained by the institutional complementarity that exists in the Dutch corporatist welfare state between the norm of job security and the normative ideals of the strategy of enhancing employability.

In this chapter, we focus on the corporatist institution of collective bargaining that is so important to Dutch labour policy and investigate the role this institution plays in risk management and the contribution it makes to the protection against old and new social risks. In this chapter, we investigate the interaction between risk protection by the welfare state and provisions in collective labour agreements. If one diminishes, how does the other react? We investigate this interaction in relation to welfare state retrenchment (is this compensated for in collective labour agreements?), in relation to old and new social risks (to what extent do collective labour agreements and the traditional institution of social security protect against new social risks?) and in relation to the decentralisation of collective labour agreements (does decentralisation lead to a decrease in risk-protection?). We learn that, as was the case in the previous chapter, the 'old' institutions of the (corporatist) welfare state play a decisive role in the birth of a 'new welfare settlement. 
As we have seen in Chapter one, within the welfare state literature there has been increased attention for the discussion of social risks. This discussion often focuses on the difference between 'old' versus 'new' social risks (Bonoli 2005; Taylor-Gooby 2004). 'Old' social risks are risks associated with industrial society in which a main breadwinner was protected against sickness, old age and disability. These risks were often seen to lie outside the responsibility of the individual, hence some call them 'external' risks. 'New' social risks are risks such as care risks and insufficient education or training, and are often referred to as 'manufactured' risks (Giddens 1998), given greater emphasis on individual responsibility. ${ }^{2}$

Increased attention for social risks is, in part, a consequence of the dual processes of globalisation and individualisation as outlined in Chapter one. Open societies and open economies challenge the collective nature of social risk protection within welfare states. At the same time, the changing nature of social risks has and will continue to put pressure on welfare states to create new policies and to adapt existing risk protection policies. There is a vastly growing literature that investigates social risks and welfare state responses (Bonoli 2007; Esping-Andersen 2002; Taylor-Gooby 2004). Cross-country comparisons have highlighted the variation in risk protection across welfare states (see, for example, Brandl and Traxler 2005; Siegel 2005). Yet welfare states are not the only providers of welfare, a point not often reflected in the literature. There is also a growing industrial relations literature on the role of the social partners in welfare state reforms (Baccaro and Simoni 2008; Ebbinghaus and Hassel 2000; Visser 2007). And while collective bargaining institutions are included in some welfare state analyses, collective bargaining outcomes are often excluded. One of the few exceptions to this is a study by Trampusch (2006). In her historical analysis of collective bargaining in the Netherlands and Germany, Trampusch finds that collectively negotiated benefits are an important factor in welfare provision. This is important, because as Brandl and Traxler (2005) have convincingly argued, collective agreements can supplement or oppose welfare state policies in many countries. Within the industrial relations literature, however, there is little attention for the role of collective agreements as welfare protection; much industrial relations literature is focused on the supposed decentralisation of collective bargaining (Katz 1993; OECD 1994), an argument for which there is much rhetoric but little empirical evidence (Traxler 1999). 
We address both of these issues in this chapter. We start by concentrating on the shortcoming in the literature by researching the outcome of collective labour agreements (CLAs) in terms of the protection of social risks in the Netherlands. We make an empirical comparison of the coverage of old and new social risks in collective labour agreements, focusing on one 'old' social risk - occupational disability insurance, and one 'new' social risk - the need for an improved work-life balance. This comparison is a logical starting point given the current challenges facing welfare providers today. This analysis contributes to the third question posed at the beginning of this book, aimed at risk management: to what extent do collective agreements provide collective solutions for risk management in the Dutch welfare state? In this chapter, we also focus on the issue of decentralisation, empirically determining whether this is taking place within Dutch collective bargaining and whether this process strengthens or weakens the protection afforded social risks (in terms of more or less collective solutions to risks) in collective bargaining arrangements.

We have selected the Netherlands as our case study due to its strong corporatist structure, in which both the government and collective bargaining structures play an important role in the creation and implementation of social risk protection. Collective labour agreements are important determinants of working conditions in the Netherlands, and despite the decline in trade union membership during the 1970s and 1980s (Visser 2006) coverage of collective labour agreements remains high in the Netherlands (OECD 1994). In fact, it is estimated that 80 to 85 per cent of all Dutch employees are covered by a collective labour agreement (Rojer 2002; Van Klaveren and Tijdens 2008; Vossen and Engelen 2002). A minor share of employees is covered by collective labour agreements as a result of the application of general extension practices, whereby collective labour agreement coverage is extended to all companies within an industry. Moreover, there is a unique opportunity to closely examine social risk protection in collective labour agreements in the Netherlands given the existence of a detailed collective labour agreement database; comparable databases are only available in Australia, Austria, Switzerland and Germany.

In the next section, we review the literature on Dutch welfare state disability policy and work-life balance policy. We draw four hypotheses from this discussion. In section three, we introduce the data before moving on to the empirical section. The empirical section starts with a focus on the protection of occupational disability and work-life balance arrangements in collective labour agreements from 1995-2009. Which collective labour agreements offer the most protection for these social risks and why? We 
then turn to the issue of decentralisation. Has decentralisation taken place since 1995 in Dutch collective labour agreements? Is risk-sharing affected by this process? The empirical section deals with each of these questions in turn. Finally, some conclusions are provided.

\section{Collective bargaining and social risk protection}

As noted in the introduction, while there are many studies that focus on the protection of social risks in welfare states or on the importance of industrial relations for welfare reform, there are few studies that focus on collective bargaining as a means of protecting against social risks. A study by Budd and Mumford looks at the availability of work-life balance policies as a result of trade union representation in the UK (2004). They find that trade union representation increases the chance that employers will offer parental leave, special paid leave and job-sharing possibilities. Heywood and Jirjahn (2009) find similar results for works council representation in German workplaces. However, the focus of these studies is the effect of workplace representation, not collective bargaining arrangements as an instrument of social protection.

We start our analysis where a study by Trampusch leaves off (2006). From this literature, we know that collective bargaining arrangements are connected to welfare state reform. During the 1980 s, occupational disability insurance had become the focal point of Dutch welfare state reform. Following decades of generous income protection, it had become clear that occupational disability insurance had increased disproportionately to other welfare programmes. Occupational disability insurance had become a means of dismissing older workers and generally circumventing less attractive exit routes, such as unemployment. To combat the evergrowing number of benefit recipients, a number of laws were passed at the start of the 1990s, just prior to the starting point of our analysis in 1995. In 1992, legislation was passed to reduce the volume of disability benefit recipients by introducing a bonus-malus system (Aarts, de Jong, and van der Veen 2002). The legislation failed and was abolished three years later. Of more importance, however, was the legislation of 1993, the Act on Reducing Disability Claims (TBA). This law tightened disability screening and clearly marked a shift towards a policy of activation rather than a policy of passive income protection in the welfare state.

As the 1990 os progressed, more reforms were undertaken. These included the Act on Extending Salary Coverage during Illness (Wet Uitbreiding 
Loondoorbetalingsplicht bij Ziekte, WULBZ) in 1996, which visibly redefined individual rights to collective insurance and shifted responsibility for income protection to employers. Employer responsibility for income protection during sickness or disability was extended from one year to two years with the renewed Poortwachter legislation of 2004 (Yerkes 2011) and in 2006, disability reform was completed with the Work and Income according to Labour Capacity Act (Wet Werk en Inkomen naar Arbeidsvermogen, WIA). This law, valid since 2006, replaced the Occupational Disability Insurance Act (Wet op de Arbeidsongeschiktheidsverzekering, WAO) that had been in place since 1967. In addition, the law created more distinct and restricted categories of benefit recipients, reducing collective protection within the welfare state and increasing employer and individual responsibility. Under the new legislation, it was assumed that employers would not compensate for more than 170 per cent of lost earnings in two years time (100\% in the first year and $70 \%$ in the second year). However, if Trampusch (2006) is correct that welfare state retrenchment is compensated for in collectively negotiated benefits, we can expect that Dutch collective bargaining will attempt to compensate for these cuts in public disability arrangements.

The compensation thesis can also be extended to the coverage of all social risks, including new social risks, hypothesising that coverage in collective labour agreements is dependent upon what is available at the level of the welfare state. In contrast to occupational disability, work-life balance issues were not on the government agenda during the early 1990 in the Netherlands. Part-time work was increasing during this period (Yerkes and Visser 2006) but was considered to be primarily a collective bargaining issue, not an issue of the welfare state. This perspective changed in 2000, with passage of the Adjustment of Working Hours Act (Wet Aanpassing Arbeidsduur, WAA), which guaranteed workers the right to increase or decrease working hours following one year of employment, dependent upon the situation in the firm. In addition, little childcare was available at this time (Tijdens and Lieon 1993) and parental leave was not provided for by the welfare state. Childcare policy, like part-time work, was also considered to be an issue for the social partners (Yerkes 2011). However, legislation creating a tripartite approach to financing childcare was implemented in 2005 , making childcare partially a state responsibility. The new law was based on the idea that the welfare state, employers and parents would each be responsible for one-third of childcare costs. Employer subsidies were voluntary under the legislation, but became mandatory in 2007 , effectively removing childcare from the collective 
bargaining table. Finally, parental leave was not provided for by the welfare state during the mid-199os (Yerkes 2006), also being considered a collective bargaining issue. Parental leave legislation was not introduced until 2001, under pressure to conform to European regulations. Part of a larger Act on Work and Care (Wet Arbeid en Zorg), the legislation guaranteed parents the right to 13 weeks of unpaid parental leave. Leave legislation was changed in 2009 so that the right to parental leave is calculated as 26 times an employee's weekly working hours and can be taken up until the child's eighth birthday. The subsidising of parental leave and/or an extension of the duration of parental leave remains an issue for collective bargaining.

Given these developments, and the importance of collective bargaining arrangements as a provider of welfare, as well as the interaction between the welfare state and collective bargaining institutions (Brandl and Traxler 2005; Rein 1982) we expect that the coverage of social risks is dependent upon welfare state protection. We differentiate between the public and private sector here to allow for possible differences between sectors in which the government has indirect input (such as education and health care) versus the private sector where this is not the case. This leads to our first hypothesis:

Hypothesis 1: If the state does not provide risk coverage for new social risks, or cuts existing coverage for old social risks, this role will be taken up by collective labour agreements, and it is assumed that these provisions do not differ between public and private sector collective labour agreements.

Second, some empirical evidence has been found to demonstrate that in a number of countries, a decentralisation of collective bargaining structures has occurred (Katz 1993; OECD 1994). In its basic form, the decentralisation thesis assumes, "that the locus of collective bargaining is shifting downward in a number of countries, often from a national or multi-company level to the firm or plant level" (Katz 1993: 3). A variety of explanations have been offered to elucidate the presence or absence of decentralisation, including expected effects from the decline of union membership, leading to increased employer influence (Katz 1993), increased competition within countries, variation in forms of governance, the growth of the service sector or the internationalisation of markets (Traxler and Kittel 2000; Zagelmeyer 2007). The most pronounced reason we should expect decentralisation, though, according to the literature, is due to a process of neo-liberalisation. 
Decentralisation is assumed to be a consequence of the neo-liberalisation of socio-economic policies, which reduced collective responsibilities and increased individual responsibilities. Initially, following the crises of the 1970s, corporatism and corporatist strategies became of increasing importance (Berger 1981; Goldthorpe 1984). In countries like Germany, Norway, Austria and Sweden, governments attempted to mediate inequalities between capital and labour through the use of corporatist policies, whereas other countries followed a market-driven neo-liberal path (Bamber, Lansbury, and Wailes 2004). Yet as economic pressures continued into the 1980 s, and as a consequence of socio-economic changes, countries supposedly began shifting away from corporatism and moving towards neo-liberalism (Traxler 1999). In that vein, neo-liberalisation is meant 'to dismantle and deregulate collective labor market institutions in order to boost performance' (Traxler 1999: 57). One of the most glaring problems with the decentralisation argument, however, is a lack of convincing empirical evidence (Traxler 1999). We investigate decentralisation by looking at the development of industry-wide and company-level bargaining across time. If the assumptions put forth in the literature hold, decentralisation should be visible in collective labour agreements from 1995 onwards.

\begin{abstract}
Hypothesis 2: If decentralisation is evident, we should see a significant increase in the number of company-level collective labour agreements in comparison to industry-wide collective labour agreements between 1995-2009. Decentralisation should be evident in both public and private sector collective labour agreements.
\end{abstract}

Another concern with the decentralisation argument is the assumption that decentralisation will lead to neo-liberal strategies in industrial relations. Following the period of neo-liberalisation during the 1980s, we have witnessed a revival of corporatist strategies and a broadening of the scope of collective bargaining structures. Scholars are in agreement that we are witnessing a renewed interest in corporatist institutional strategies (Mailand 2007). Governments increasingly seek concertation with employers and/or trade unions (Baccaro and Simoni 2008). In some countries, governments increasingly seek out the assistance of the social partners as a means of blame avoidance in their quests for welfare reform (Baccaro and Simoni 2008; Visser 2007). Bi- and tripartite forms of concertation are even visible in countries lacking a corporatist industrial relations history, such as Italy and Ireland (Baccaro 2003). Moreover, various manners of tripartite policy-making began to emerge in post-communist 
European countries (Avdagic 2006). The consequences of this development have not been discussed in terms of decentralisation.

At the same time, the scope of collective bargaining has widened in many countries. Collective bargaining is no longer restricted to wage determination and policies associated with the industrial economy, such as pensions and disability coverage. Rather, collective bargaining increasingly deals with a range of social protection and welfare state issues, 'such as the introduction of new technologies, health and safety issues or the allocation of working hours across days of the week' (Wallerstein, Golden, and Lange 1997: 381). In fact, in some countries collective bargaining has been expanded to include protection for a wide variety of labour market risks, not only working time arrangements and health and safety issues, but employability and work-life aspects as well (Budd and Mumford 2004; Schreuder 2008).

In addition, company-level collective labour agreements are assumed to be more attuned to the changing needs and preferences of employers (Nagelkerke and de Nijs 2003). Company-level collective labour agreements provide employers with room to customise collective labour agreements to their needs, allowing them to respond quickly to the changing work environment. Given this increased ability to customise collective labour agreements, it is plausible that company-level collective labour agreements will be able to respond to new social risks more quickly as the need arises than industry-wide collective labour agreements. In contrast, decentralisation is - as said before - also assumed to go hand-in-hand with neo-liberalisation. If this is true, we should see decreased social risk protection, in particular in company-level collective labour agreements, not increased protection in the case of customisation. To determine which hypothesis is more valid, we test both:

Hypothesis 3a: If decentralisation leads to customisation in collective labour agreements, there will be a difference in risk protection provided by company-level and industry-wide collective labour agreements, with company-level collective labour agreements providing more protection for social risks than industry-wide collective labour agreements.

Hypothesis 3 b: If decentralisation goes hand-in-hand with neo-liberalism, there will be an overall decrease in risk protection in company-level collective labour agreements, more so than in industry-wide collective labour agreements.

We examine these hypotheses in section four. 
We use data from the longitudinal panel database FNV CAO-Database (Ducadam), which contains detailed information on collective labour agreements concluded in the Netherlands from 1995 onwards (for more information see Schreuder and Tijdens 2004). The FNV CAO-database includes both textual and coded information on all collective labour agreements bargained by the largest Dutch trade union confederation, the FNV. The textual part is an online database that stores texts of collective agreements, bargaining agendas, pamphlets and legal documents. The coded part of the database covers information for more than a thousand variables, whereby the FNV codes each new or prolonged collective agreement according to these variables. The data include detailed information about the protective clauses included in collective labour agreements. One of the authors has supplemented this data with information on the division of collective labour agreements into the public and private sector and with information on the level at which the collective labour agreement was concluded (company level or industrywide).

This data project began in 1995, and FNV gradually completed the database. The database was converted to a statistical database (in SPSS) in 2003 by the University of Amsterdam and the Amsterdam Institute for Labour Studies (AIAS). In 2009, the dataset held 1765 unique collective labour agreements, which represent a total of 8030 consecutive agreements, covering the years 1995 to 2009. On average, a collective labour agreement lasts for one to two years, and is then renewed. On average, each collective labour agreement is present 7.3 times in the database.

Although the exact number of collective labour agreements is not known in the Netherlands, and this number varies over time, a rough estimate indicates that trade union confederation FNV is a bargaining partner in 90 per cent of all collective labour agreements, and thus the FNV CAO-database covers 90 per cent of all agreements. Taking into account that 80 to 85 per cent of all Dutch employees are covered by a collective labour agreement, the FNV CAO-database is estimated to hold information on collective labour agreements covering more than two-thirds of the Dutch labour force in dependent employment. The collective bargaining agreement is our unit of analysis here, focusing on the share of agreements that offer a specific arrangement, the level at which the agreement is concluded (industry-wide versus company-level) and sector of agreement (public versus private). 
The empirical analysis is divided into three parts. First, we look at the share of occupational disability and work-life balance arrangements in collective labour agreements. To measure protection of the combination of work and care, we look for evidence of the following three arrangements: 1) the right to part-time work, demonstrating the right to reduce one's working hours but keep the same job; 2) childcare arrangements; and 3) supplemental (beyond legal requirements) parental leave. To measure occupational disability coverage, we focus on financial support, looking for evidence of: 1) supplemental income during the first year of illness or disability; 2) supplemental income during the second year of illness or disability and 3) the percentage of supplemental income provided for during the second year of illness or disability. Second, we consider whether decentralisation has taken place by looking at the share of agreements concluded at the company level and industry level from 1995 onwards. Lastly, we measure the share of collective agreements that offer occupational disability and work-life balance arrangements in both companylevel and industry-wide agreements.

\section{Results}

4.1 Do collective labour agreements protect against social risks?

Starting with work-life balance arrangements, the data show that collective bargaining agreements in the Netherlands already offered a particularly high share of protection for the right to part-time work and childcare prior to legislation being introduced in 2000 and 2005 respectively (see Figure 1). Supplemental parental leave is provided for in only a small share of collective agreements. The latter is possibly explained by the gendered nature of work and care in the Netherlands; women are more likely than men to take on caring duties in the Netherlands (Yerkes 2009). Given Dutch women's propensity to work part-time and to use part-time childcare to combine work and care (SCP 2006), parental leave is not as welldeveloped as childcare and part-time work arrangements. This question remains an issue for further research. We also note that while collective agreements compensate for a lack of government policy in work-life areas, they also appear to respond to legislation once it is developed. Following the introduction of working hours legislation in 2000 , the share of collective agreements providing a right to part-time work increased from 48 per cent to 88 per cent in 2009. 
Figure 1 Work-life coverage in collective bargaining in the Netherlands, across all industries, 1995-2009

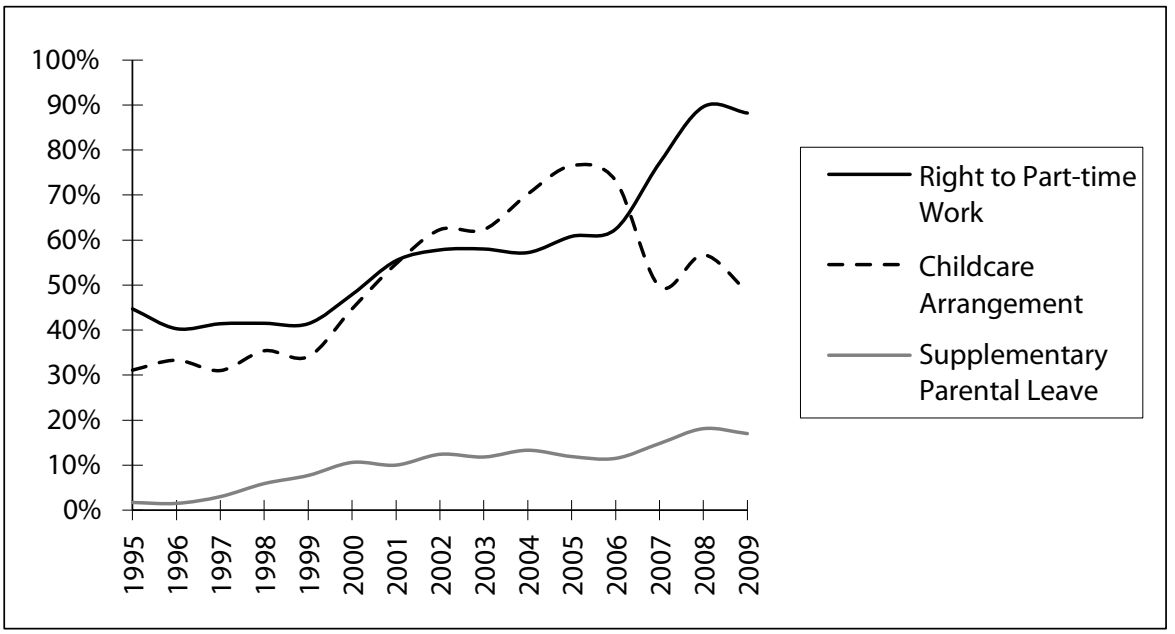

Source: Authors' own calculations based on Ducadam dataset (1995-2009)

A similar decrease is visible with childcare. Following the childcare legislation of 2005 , the share of collective agreements offering childcare arrangements decreased from 73 per cent in 2006 to 50 per cent, and following the legislation of mandatory employer subsidies in 2007 it continues to decline even further. In sum, our data confirm and further develop earlier conclusions by Trampusch (2006), showing that compensation for public welfare through collective bargaining can occur both in areas of reform as well as under-developed policy areas, as is the case with many new social risks.

In terms of occupational disability, we see that at the start of our analysis in 1995, less than five per cent of all collective agreements offered supplemental disability benefits in the first or second year of illness or disability (see Figure 2). These initial results are not surprising, as the reform of disability policy in the Dutch welfare state had, until that point, remained limited. However, we see that starting in 1998, two years following the legislative reform requiring employers to cover the first six weeks of illness or disability, that the share of collective agreements with supplemental disability benefits is rising. The share of agreements offering these benefits continues to rise as employers and individual employees are increasingly held financially responsible for the initial period of sickness or disability. As discussed above, in 2002, employers were mandated to cover financially the first full year of sickness or disability, and in 2004 this period was extended to two years. We 
see a clear response in collective agreements to offer supplemental income protection in these two years. Moreover, the data demonstrate that the share of collective agreements that offer 70 per cent income supplement or higher in the second year grew from 56 per cent in 2004 to 71 per cent within two years, compensating for cuts in public benefits.

Figure 2 Disability coverage in collective bargaining in the Netherlands, across all industries, 1995-2009

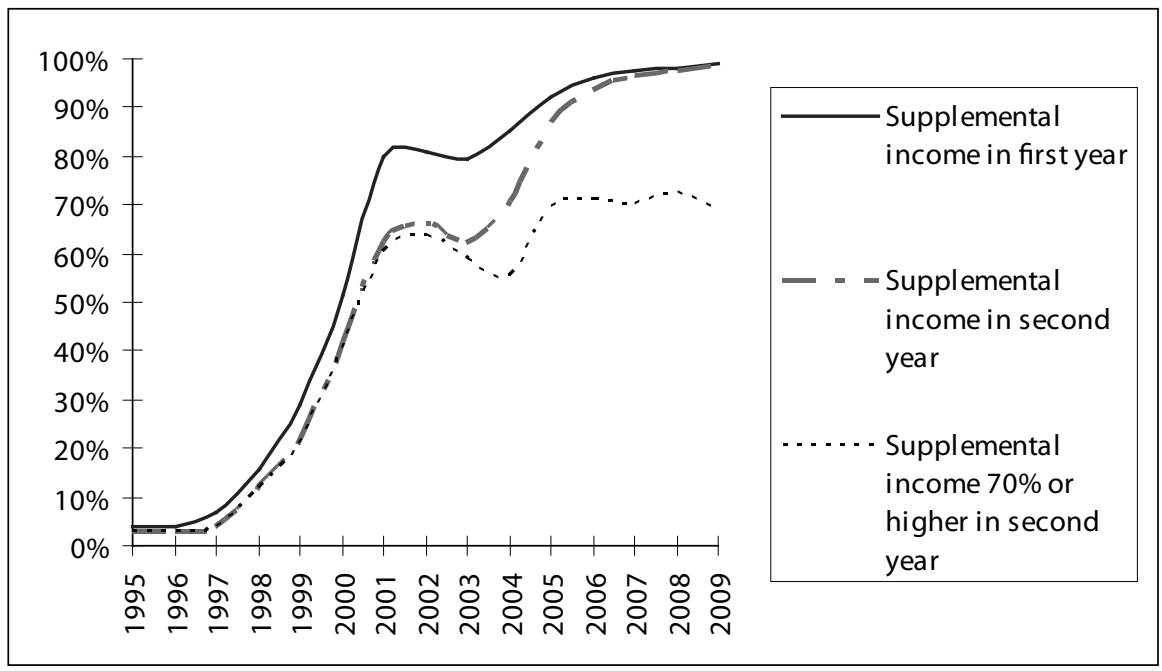

Source: Authors' own calculations based on Ducadam dataset (1995-2009)

Does this protection vary across sectors? The data demonstrate that in terms of disability coverage, initially a greater share of public sector collective agreements provided compensation for changes in welfare state provision (see Table 1). However, following 2001, we see a decline in coverage in public sector collective agreements while the share of private sector agreements with supplemental coverage continued to increase. The smaller share of collective agreements in the public sector goes against earlier findings (Boyne, Jenkins, and Pools 1999). In terms of work-life arrangements, a greater share of public sector collective agreements provide supplementary parental leave, but private sector collective agreements provide a greater share of collectively negotiated part-time work rights and childcare arrangements. Our first expectation is therefore partially confirmed by the data. Collective agreements offer compensation for a decline 
in or lack of welfare state policy, yet some differences are visible between the public and private sector. These sector-level differences are in contrast to recent findings from Schils and Houwing (2010), who find evidence of convergence across sectors in collectively bargained flexicurity arrangements, with some persistent variation evident in the utilities, education and services sector. We discuss the implications of our findings below.

Table 1 Share of disability arrangements in public and private industry collective agreements (in percentages; 1995-2009)

\begin{tabular}{|c|c|c|c|c|c|c|c|}
\hline Year & $\begin{array}{l}\text { Public } \\
\text { or } \\
\text { Private }\end{array}$ & $\begin{array}{l}\text { 1st year } \\
\text { supple- } \\
\text { ment }\end{array}$ & $\begin{array}{l}\text { 2nd year } \\
\text { supple- } \\
\text { ment }\end{array}$ & $\begin{array}{l}\text { Supple- } \\
\text { ment }>= \\
70 \%\end{array}$ & $\begin{array}{l}\text { Part-time } \\
\text { work }\end{array}$ & Childcare & $\begin{array}{l}\text { Supple- } \\
\text { mental } \\
\text { parental } \\
\text { leave }\end{array}$ \\
\hline 1995 & $\begin{array}{l}\text { Public } \\
\text { Private }\end{array}$ & $\begin{array}{l}50.0 \\
3.4\end{array}$ & $\begin{array}{l}50.0 \\
2.6\end{array}$ & $\begin{array}{l}50.0 \\
2.6\end{array}$ & $\begin{array}{l}50.0 \\
44.6\end{array}$ & $\begin{array}{c}0.0 \\
31.3\end{array}$ & $\begin{array}{l}0.0 \\
1.7\end{array}$ \\
\hline 1996 & $\begin{array}{l}\text { Public } \\
\text { Private }\end{array}$ & $\begin{array}{c}0.0 \\
3.8\end{array}$ & $\begin{array}{l}0.0 \\
3.0\end{array}$ & $\begin{array}{l}0.0 \\
3.0\end{array}$ & $\begin{array}{l}0.0 \\
40.8\end{array}$ & $\begin{array}{l}0.0 \\
33.8\end{array}$ & $\begin{array}{l}0.0 \\
1.5\end{array}$ \\
\hline 1997 & $\begin{array}{l}\text { Public } \\
\text { Private }\end{array}$ & $\begin{array}{l}40.0 \\
5.8\end{array}$ & $\begin{array}{l}40.0 \\
2.8\end{array}$ & $\begin{array}{l}40.0 \\
2.8\end{array}$ & $\begin{array}{l}22.2 \\
41.9\end{array}$ & $\begin{array}{l}33.3 \\
31.0\end{array}$ & $\begin{array}{l}11.1 \\
2.8\end{array}$ \\
\hline 1998 & $\begin{array}{l}\text { Public } \\
\text { Private }\end{array}$ & $\begin{array}{l}54.5 \\
13.8\end{array}$ & $\begin{array}{l}45.5 \\
10.7\end{array}$ & $\begin{array}{l}40.9 \\
10.3\end{array}$ & $\begin{array}{l}31.8 \\
41.9\end{array}$ & $\begin{array}{l}27.3 \\
35.7\end{array}$ & $\begin{array}{l}13.6 \\
5.5\end{array}$ \\
\hline 1999 & $\begin{array}{l}\text { Public } \\
\text { Private }\end{array}$ & $\begin{array}{l}50.0 \\
27.1\end{array}$ & $\begin{array}{l}40.9 \\
19.7\end{array}$ & $\begin{array}{l}40.9 \\
19.0\end{array}$ & $\begin{array}{l}34.1 \\
42.1\end{array}$ & $\begin{array}{l}27.3 \\
34.7\end{array}$ & $\begin{array}{l}27.3 \\
5.9\end{array}$ \\
\hline 2000 & $\begin{array}{l}\text { Public } \\
\text { Private }\end{array}$ & $\begin{array}{l}74.0 \\
49.3\end{array}$ & $\begin{array}{l}60.0 \\
40.1\end{array}$ & $\begin{array}{l}56.0 \\
39.2\end{array}$ & $\begin{array}{l}38.0 \\
48.8\end{array}$ & $\begin{array}{l}28.0 \\
46.2\end{array}$ & $\begin{array}{l}10.0 \\
10.7\end{array}$ \\
\hline 2001 & $\begin{array}{l}\text { Public } \\
\text { Private }\end{array}$ & $\begin{array}{l}88.1 \\
79.4\end{array}$ & $\begin{array}{l}76.2 \\
61.4\end{array}$ & $\begin{array}{l}76.2 \\
59.0\end{array}$ & $\begin{array}{l}42.9 \\
56.3\end{array}$ & $\begin{array}{l}47.6 \\
55.2\end{array}$ & $\begin{array}{l}23.8 \\
9.0\end{array}$ \\
\hline 2002 & $\begin{array}{l}\text { Public } \\
\text { Private }\end{array}$ & $\begin{array}{l}71.7 \\
81.6\end{array}$ & $\begin{array}{l}60.4 \\
66.7\end{array}$ & $\begin{array}{l}60.4 \\
63.8\end{array}$ & $\begin{array}{l}43.4 \\
59.2 \\
\end{array}$ & $\begin{array}{l}58.5 \\
62.6\end{array}$ & $\begin{array}{l}22.6 \\
11.5\end{array}$ \\
\hline 2003 & $\begin{array}{l}\text { Public } \\
\text { Private }\end{array}$ & $\begin{array}{l}62.1 \\
81.1\end{array}$ & $\begin{array}{l}58.6 \\
62.5\end{array}$ & $\begin{array}{l}55.2 \\
59.1\end{array}$ & $\begin{array}{l}43.9 \\
59.3\end{array}$ & $\begin{array}{l}65.5 \\
62.0\end{array}$ & $\begin{array}{l}17.5 \\
11.3\end{array}$ \\
\hline 2004 & $\begin{array}{l}\text { Public } \\
\text { Private }\end{array}$ & $\begin{array}{l}71.0 \\
86.7\end{array}$ & $\begin{array}{l}62.3 \\
71.5\end{array}$ & $\begin{array}{l}44.9 \\
56.7\end{array}$ & $\begin{array}{l}47.8 \\
58.1\end{array}$ & $\begin{array}{l}75.0 \\
69.7\end{array}$ & $\begin{array}{l}22.4 \\
12.3\end{array}$ \\
\hline 2005 & $\begin{array}{l}\text { Public } \\
\text { Private }\end{array}$ & $\begin{array}{l}79.0 \\
93.7\end{array}$ & $\begin{array}{l}74.2 \\
88.1\end{array}$ & $\begin{array}{l}46.8 \\
71.6\end{array}$ & $\begin{array}{l}42.6 \\
62.5\end{array}$ & $\begin{array}{l}73.8 \\
76.8\end{array}$ & $\begin{array}{l}19.7 \\
11.1\end{array}$ \\
\hline 2006 & $\begin{array}{l}\text { Public } \\
\text { Private }\end{array}$ & $\begin{array}{l}92.5 \\
96.5\end{array}$ & $\begin{array}{l}89.6 \\
94.2\end{array}$ & $\begin{array}{l}49.3 \\
74.1\end{array}$ & $\begin{array}{l}51.6 \\
64.0\end{array}$ & $\begin{array}{l}72.3 \\
73.4\end{array}$ & $\begin{array}{l}20.6 \\
10.1\end{array}$ \\
\hline 2007 & $\begin{array}{l}\text { Public } \\
\text { Private }\end{array}$ & $\begin{array}{l}95.4 \\
97.8\end{array}$ & $\begin{array}{l}93.8 \\
97.0\end{array}$ & $\begin{array}{l}41.5 \\
73.3\end{array}$ & $\begin{array}{l}69.0 \\
77.9\end{array}$ & $\begin{array}{l}48.1 \\
49.9\end{array}$ & $\begin{array}{l}11.3 \\
15.2\end{array}$ \\
\hline 2008 & $\begin{array}{l}\text { Public } \\
\text { Private }\end{array}$ & $\begin{array}{l}98.1 \\
98.2\end{array}$ & $\begin{array}{l}96.2 \\
97.6\end{array}$ & $\begin{array}{l}36.5 \\
76.5 \\
\end{array}$ & $\begin{array}{l}80.4 \\
90.6\end{array}$ & $\begin{array}{l}45.9 \\
57.9\end{array}$ & $\begin{array}{l}24.1 \\
17.2\end{array}$ \\
\hline 2009 & $\begin{array}{l}\text { Public } \\
\text { Private }\end{array}$ & $\begin{array}{l}97.1 \\
99.5\end{array}$ & $\begin{array}{l}97.1 \\
99.0\end{array}$ & $\begin{array}{l}42.9 \\
73.7\end{array}$ & $\begin{array}{l}78.1 \\
89.9\end{array}$ & $\begin{array}{l}62.5 \\
46.5\end{array}$ & $\begin{array}{l}30.0 \\
15.0\end{array}$ \\
\hline
\end{tabular}

Source: Authors' own calculations based on Ducadam dataset (1995-2009) 


\subsection{Is decentralisation evident?}

Next, we consider the decentralisation thesis. We start by measuring decentralisation as an increase in the proportion of company-level collective labour agreements in relation to the proportion of industry-wide collective labour agreements each year. We analysed a total of 8,411 collective labour agreements present in the database between 1995 and 2009. ${ }^{3}$ On average, 77 per cent of these collective labour agreements were company-level collective labour agreements and 23 per cent were industry-wide collective labour agreements during this period. Hence, it seems there is a greater propensity towards collective labour agreements at lower levels of collective bargaining (see Figure 3 ). ${ }^{4}$ Taking a closer look, however, we see that these averages do not tell us the whole story. By 2009, only 64 per cent of collective labour agreements were company-level collective labour agreements, a 24 per cent decrease from 1995. This represents a significant decrease across time (measured as the correlation between the percentage of company-wide collective labour agreements and year) and is indicative of a clear overall trend of centralisation in Dutch collective bargaining, rather than decentralisation as is assumed in hypothesis two.

Figure 3 Annual percentage of company-level CLAs in relation to all CLAs in the Netherlands, public and private sector combined, 1995-2009 ( $N=8,411)$

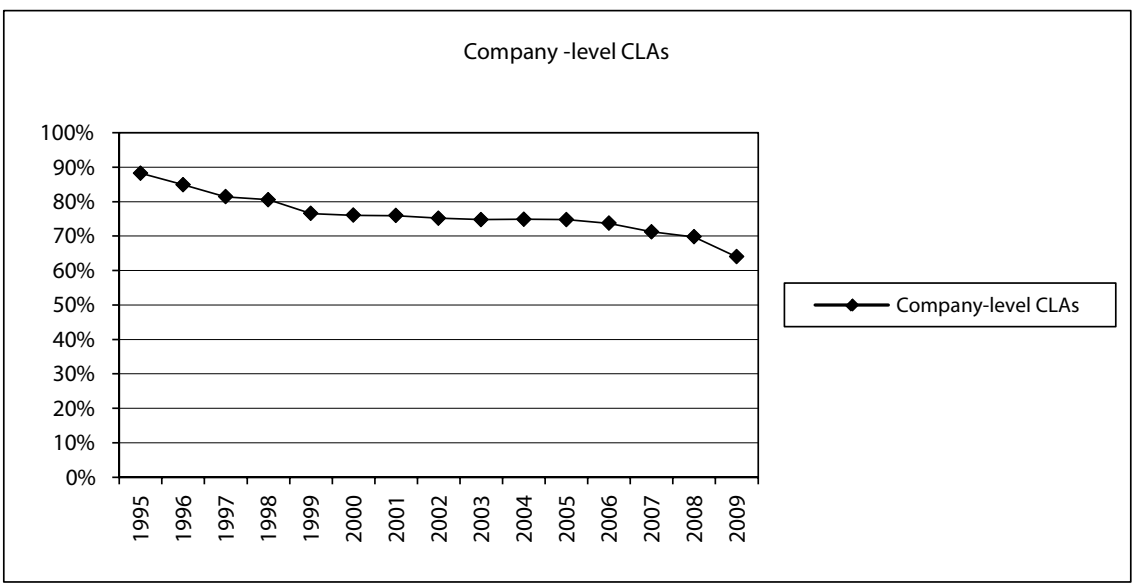

Source: Authors' own calculations based on Ducadam dataset (1995-2009)

** Two-tailed t-test shows a significant decline in company-level CLAs across time (0.01 level). 
Next, we look at the number of company and industry-wide collective labour agreements in greater detail, differentiating between the public and private sector. When we do this, we see that the private sector is characterised by a large number of company-level collective labour agreements. On average, from 1995-2009 79 per cent of collective labour agreements in private industries were company-level collective labour agreements. Only 21 per cent of collective labour agreements in the private sector were industry-wide collective labour agreements during this period. In comparison, the public sector had nearly twice as many industry-wide collective labour agreements. On average, 39 per cent of public sector collective labour agreements were agreed upon at the industry-wide level. An average of 61 per cent of public sector collective labour agreements were at the company level during this same period.

Taking a closer look at the relationship between the percentage of company-level collective labour agreements and year, the data demonstrate a small increase in company-level collective labour agreements in the public sector (see Figure 4; measured as a correlation between the proportion of company-level collective labour agreements and year, not significant at the 0.10 level). We cannot say the same for private industries (see Figure 5). In private sector collective labour agreements, the data demonstrate a significant increase in industry-wide collective labour agreements. While nearly 90 per cent of the collective labour agreements concluded in the private sector in 1995 were at the company level, this decreased to 65 per cent by 2009, showing a clear trend of centralisation within the private

Figure 4 Annual percentage of company-level CLAs in relation to all CLAs in the Netherlands within the public sector, 1995-2009 $(\mathrm{N}=1,197)$

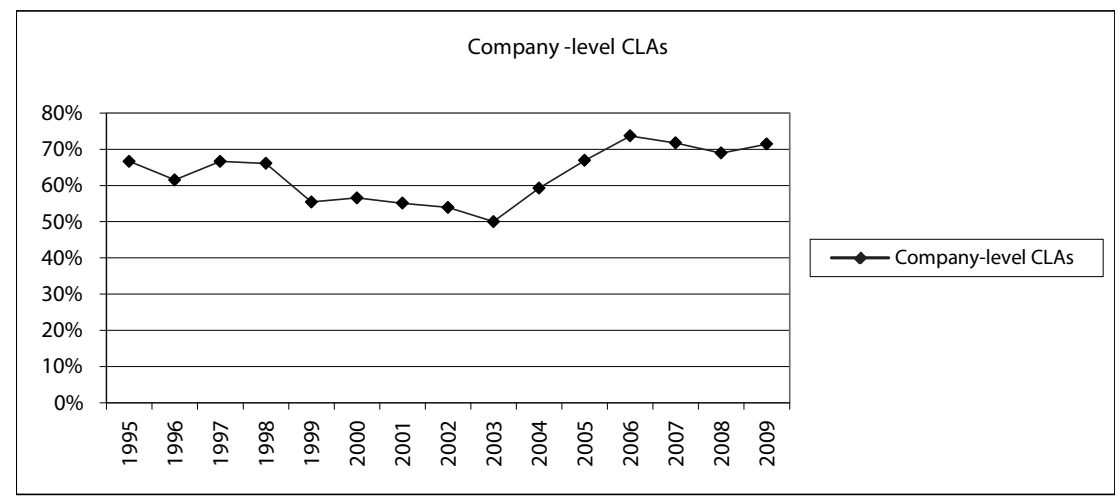

Source: Authors' own calculations based on Ducadam dataset (1995-2009) 
Figure 5 Annual percentage of company-level CLAs in relation to all CLAs in the Netherlands within the private sector, 1995-2009 $(\mathrm{N}=7,214)$

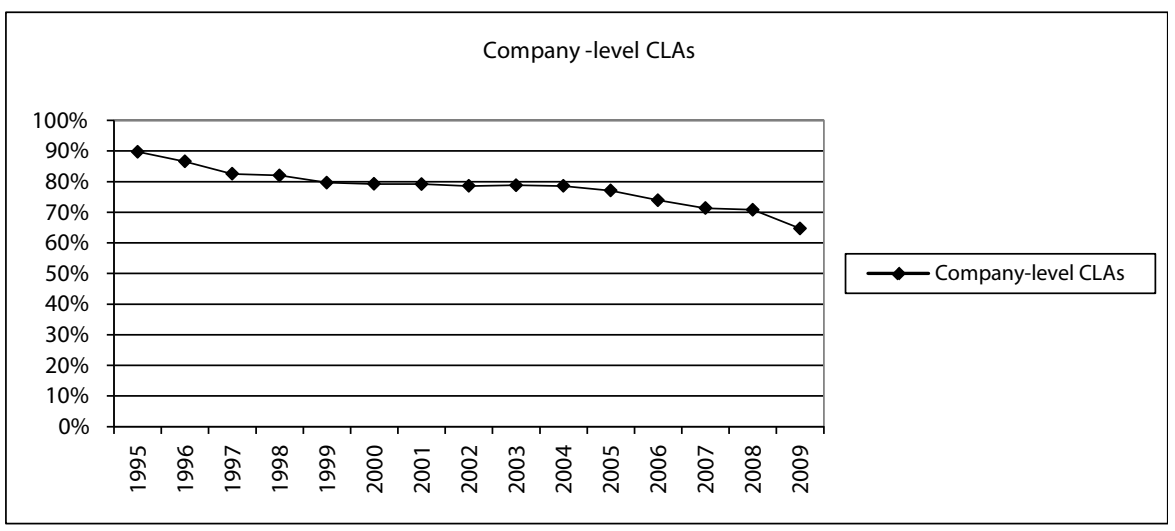

Source: Authors' own calculations based on Ducadam dataset (1995-2009)

** Two-tailed t-test shows a significant decline in company-level CLAs across time (0.01 level).

sector since the mid-199os. We must therefore reject our second hypothesis. Despite a minor trend towards decentralisation in the public sector, a trend which is not statistically significant, the overall trend in collective bargaining in the Netherlands is towards more industry-wide collective labour agreements than company-level collective labour agreements on an annual basis. We turn to the implications of these findings in the conclusions.

\subsection{Centralisation and risk sharing}

Lastly, the final step in the analysis considers what the effects of this centralisation are for risk-sharing in CLAs. Are there differences in the protection of both work-life balance and occupational disability in industry-wide and company-level CLAs? The results are presented in Table 2. Looking at the availability of part-time work, childcare and supplemental parental leave arrangements, we see that while company-level agreements initially provide more protection in terms of the right to part-time work, by the time legislation is passed in 2000 , both company-level and industry-wide collective agreements offer a similar degree of protection. In regards to childcare, company-level collective agreements appear to lag behind industry-wide agreements. Lastly, little difference can be found in 
Table 2 Share of disability arrangements in industry-wide and company-level collective agreements (in percentages; 1995-2009)

\begin{tabular}{|c|c|c|c|c|c|c|c|}
\hline Year & $\begin{array}{l}\text { Indus- } \\
\text { try-wide } \\
\text { (IW) or } \\
\text { compa- } \\
\text { ny-level } \\
\text { (CL) }\end{array}$ & $\begin{array}{l}\text { 1st year } \\
\text { supple- } \\
\text { ment }\end{array}$ & $\begin{array}{l}\text { 2nd year } \\
\text { supple- } \\
\text { ment }\end{array}$ & $\begin{array}{l}\text { Supple- } \\
\text { ment }> \\
=70\end{array}$ & $\begin{array}{l}\text { Part-time } \\
\text { work }\end{array}$ & Childcare & $\begin{array}{l}\text { Supple- } \\
\text { mental } \\
\text { parental } \\
\text { leave }\end{array}$ \\
\hline 1995 & $\begin{array}{l}\text { IW } \\
\mathrm{CL}\end{array}$ & $\begin{array}{l}17.9 \\
1.9\end{array}$ & $\begin{array}{l}17.9 \\
1.0\end{array}$ & $\begin{array}{l}17.9 \\
1.0\end{array}$ & $\begin{array}{l}35.7 \\
45.9\end{array}$ & $\begin{array}{l}17.9 \\
32.9\end{array}$ & $\begin{array}{l}3.6 \\
1.4\end{array}$ \\
\hline 1996 & $\begin{array}{l}\text { IW } \\
\mathrm{CL}\end{array}$ & $\begin{array}{l}5.9 \\
3.4\end{array}$ & $\begin{array}{l}3.9 \\
2.8\end{array}$ & $\begin{array}{l}3.9 \\
2.8\end{array}$ & $\begin{array}{l}29.4 \\
42.1\end{array}$ & $\begin{array}{l}47.1 \\
31.5\end{array}$ & $\begin{array}{l}2.0 \\
1.4\end{array}$ \\
\hline 1997 & $\begin{array}{l}\text { IW } \\
\mathrm{CL}\end{array}$ & $\begin{array}{l}10.7 \\
5.8\end{array}$ & $\begin{array}{l}6.7 \\
3.0\end{array}$ & $\begin{array}{l}6.7 \\
3.0\end{array}$ & $\begin{array}{l}35.1 \\
43.0\end{array}$ & $\begin{array}{l}39.2 \\
29.3\end{array}$ & $\begin{array}{l}4.1 \\
2.7\end{array}$ \\
\hline 1998 & $\begin{array}{l}\text { IW } \\
\mathrm{CL}\end{array}$ & $\begin{array}{l}23.5 \\
13.7\end{array}$ & $\begin{array}{l}22.4 \\
9.8\end{array}$ & $\begin{array}{l}22.4 \\
9.1\end{array}$ & $\begin{array}{l}42.9 \\
41.4\end{array}$ & $\begin{array}{l}40.8 \\
34.3\end{array}$ & $\begin{array}{l}4.1 \\
6.4\end{array}$ \\
\hline 1999 & $\begin{array}{l}\mathrm{IW} \\
\mathrm{CL}\end{array}$ & $\begin{array}{l}31.6 \\
28.4 \\
\end{array}$ & $\begin{array}{l}24.8 \\
20.6 \\
\end{array}$ & $\begin{array}{l}24.8 \\
19.8 \\
\end{array}$ & $\begin{array}{l}37.6 \\
42.6 \\
\end{array}$ & $\begin{array}{l}32.5 \\
34.6 \\
\end{array}$ & $\begin{array}{l}8.5 \\
7.5 \\
\end{array}$ \\
\hline 2000 & $\begin{array}{l}\text { IW } \\
\mathrm{CL}\end{array}$ & $\begin{array}{l}59.7 \\
49.0 \\
\end{array}$ & $\begin{array}{l}50.0 \\
39.4 \\
\end{array}$ & $\begin{array}{l}49.3 \\
38.1 \\
\end{array}$ & $\begin{array}{l}49.3 \\
47.5 \\
\end{array}$ & $\begin{array}{l}54.5 \\
42.0 \\
\end{array}$ & $\begin{array}{l}15.7 \\
9.2 \\
\end{array}$ \\
\hline 2001 & $\begin{array}{l}\text { IW } \\
\mathrm{CL}\end{array}$ & $\begin{array}{l}78.4 \\
80.4 \\
\end{array}$ & $\begin{array}{l}65.5 \\
61.5 \\
\end{array}$ & $\begin{array}{l}62.6 \\
59.5 \\
\end{array}$ & $\begin{array}{l}56.1 \\
55.2 \\
\end{array}$ & $\begin{array}{l}56.8 \\
54.0 \\
\end{array}$ & $\begin{array}{l}7.9 \\
10.5 \\
\end{array}$ \\
\hline 2002 & $\begin{array}{l}\text { IW } \\
\mathrm{CL}\end{array}$ & $\begin{array}{l}79.7 \\
81.1\end{array}$ & $\begin{array}{l}67.7 \\
65.7\end{array}$ & $\begin{array}{l}64.7 \\
63.2\end{array}$ & $\begin{array}{l}59.4 \\
57.4\end{array}$ & $\begin{array}{l}65.4 \\
61.4\end{array}$ & $\begin{array}{l}12.0 \\
12.6\end{array}$ \\
\hline 2003 & IW & 81.6 & 68.4 & 66.4 & 63.2 & 67.1 & 13.6 \\
\hline 2004 & $\mathrm{CL}$ & $\begin{array}{l}79.0 \\
85.8\end{array}$ & 60.5 & 56.7 & 56.5 & 60.9 & $\begin{array}{l}11.3 \\
137\end{array}$ \\
\hline & $\mathrm{CL}$ & 85.1 & 69.9 & 55.5 & 56.0 & 68.2 & 13.2 \\
\hline 2005 & $\begin{array}{l}\text { IW } \\
\mathrm{CL}\end{array}$ & $\begin{array}{l}92.6 \\
92.4\end{array}$ & $\begin{array}{l}86.5 \\
87.0\end{array}$ & $\begin{array}{l}66.2 \\
70.3 \\
\end{array}$ & $\begin{array}{l}63.9 \\
60.0 \\
\end{array}$ & $\begin{array}{l}79.5 \\
75.7 \\
\end{array}$ & $\begin{array}{l}11.2 \\
12.1 \\
\end{array}$ \\
\hline 2006 & $\begin{array}{l}\text { IW } \\
\mathrm{CL}\end{array}$ & $\begin{array}{l}99.0 \\
95.5\end{array}$ & $\begin{array}{l}96.0 \\
93.3\end{array}$ & $\begin{array}{l}66.7 \\
72.1\end{array}$ & $\begin{array}{l}64.6 \\
62.0\end{array}$ & $\begin{array}{l}72.4 \\
73.6\end{array}$ & $\begin{array}{l}12.4 \\
11.3\end{array}$ \\
\hline 2007 & $\begin{array}{l}\text { IW } \\
\mathrm{CL}\end{array}$ & $\begin{array}{l}96.7 \\
98.0 \\
\end{array}$ & $\begin{array}{l}95.9 \\
97.0\end{array}$ & $\begin{array}{l}58.2 \\
73.0 \\
\end{array}$ & $\begin{array}{l}82.1 \\
75.8 \\
\end{array}$ & $\begin{array}{l}49.1 \\
49.9 \\
\end{array}$ & $\begin{array}{l}9.3 \\
16.3 \\
\end{array}$ \\
\hline 2008 & $\begin{array}{l}\text { IW } \\
\mathrm{CL}\end{array}$ & $\begin{array}{l}99.0 \\
98.2 \\
\end{array}$ & $\begin{array}{l}98.1 \\
97.5\end{array}$ & $\begin{array}{l}67.0 \\
73.9 \\
\end{array}$ & $\begin{array}{l}93.5 \\
88.5\end{array}$ & $\begin{array}{l}62.0 \\
55.2 \\
\end{array}$ & $\begin{array}{l}19.6 \\
17.7 \\
\end{array}$ \\
\hline 2009 & $\begin{array}{l}\text { IW } \\
\mathrm{CL}\end{array}$ & $\begin{array}{l}98.1 \\
99.5\end{array}$ & $\begin{array}{l}98.1 \\
98.9\end{array}$ & $\begin{array}{l}62.3 \\
71.0\end{array}$ & $\begin{array}{l}87.8 \\
88.3\end{array}$ & $\begin{array}{l}54.5 \\
46.7\end{array}$ & $\begin{array}{l}12.5 \\
18.3\end{array}$ \\
\hline
\end{tabular}

Source: Authors' own calculations based on Ducadam dataset (1995-2009)

the share of industry-wide and company-level collective agreements that provide supplemental parental leave.

In regard to disability protection, both company-level collective agreements and industry-wide agreements offer a similar level of protection. 
The share of agreements offering supplemental income in the first and second year of illness is minimally smaller in company-level agreements in comparison to industry-wide agreements. The only relatively large difference between company-level and industry-wide agreements in the protection of disability became visible following the most recent reform of disability legislation in 2006. While the share of industry-wide collective agreements supplementing income at a level of 70 per cent or higher declined after this point, the share of company-level agreements providing 70 per cent or higher income supplementation increased slightly and remains roughly 10 per cent higher than in industry-wide agreements. Hypotheses $3 \mathrm{a}$ and $3 \mathrm{~b}$ are not confirmed. No major differences are found between company-level and industry-wide agreements, and no decentralisation is evident.

\section{Conclusions}

In this chapter, we have focused on risk management in the Dutch welfare state, specifically addressing social risk management in relation to collective labour agreements. We analysed if work-family balance arrangements, which aim to cover so-called new social risks, and occupational disability arrangements, covering traditional risks, were provided for in Dutch collective labour agreements from 1995-2009, in response to the absence of or decrease in coverage by the welfare state. The results show that in regard to both old and new social risks, collective labour agreements are likely to provide coverage in areas where the welfare state provides little to no protection or where protection has declined. Few differences exist between the public and private sector in this regard. In other words, in the new Dutch welfare settlement, collective agreements can compensate for a lack of or change in risk management in the welfare state. Furthermore, we have shown that decentralisation, measured as the number of company-level collective labour agreements in comparison to industry-wide collective labour agreements on an annual basis, is not occurring in the Netherlands. There is evidence of centralisation taking place in Dutch collective bargaining since the mid-199os. Moreover, there are few differences between company-level and industry-level collective labour agreements in regards to social risk protection. The absence of differentiation likely points to the constraining effect of a corporatist welfare state; given strong collective coordination, it is plausible that company-level collective labour agreements differ little from industry-wide collective labour agreements. 
The data point to a number of possible implications of centralisation for our understanding of risk-sharing in the welfare state. One consequence of this centralisation for risk sharing could include even greater coverage of work-family issues in collective labour agreements in the near future, given the larger increase in work-family balance arrangements in industry-wide collective labour agreements in comparison to companylevel collective labour agreements. Another consequence of centralisation is a growing convergence in risk coverage in collective agreements and the ability of collective bargaining agreements to compensate for welfare state policy. ${ }^{5}$

In relation to the questions posed in Chapter one, these findings point to an important factor in social risk protection and welfare provision in general. We have shown that collective agreements can offer compensation for cuts in or the absence of collective protection in the welfare state, a nuance often missing in more generalised studies of risk protection in welfare regimes (Esping-Andersen 1990; Esping-Andersen 1999). In addition, this chapter shows the flexibility of the Dutch corporatist structure in providing collective coverage of new social risks (see also Yerkes 2011). In other words, the new Dutch welfare settlement, while developing along the lines of welfare and workfare, does not represent a shift towards a more liberalised welfare state, in the Anglo-American style. The importance of the interaction between collective welfare state protection and protection offered by collective agreements (or other sources) in countries beyond the Dutch case, requires further investigation. It is clear, however, that in the Netherlands, collective agreements play an integral role in social risk management.

\section{Notes}

1 Parts of this chapter are taken from Yerkes, M. and K. Tijdens, 2010. "Social Risk Protection in Collective Labour Agreements: Evidence from the Netherlands." European Journal of Industrial Relations, 16(4): 369-383.

2 Although the presence of 'new' social risks was obscured by the presence of strong, nuclear families and other institutional arrangements that absorbed these risks, these risks are not necessarily new. Taylor-Gooby, however, makes a useful distinction in this regard. New social risks are 'significant but transitory and particular' (Taylor-Gooby 2004: 8) and are most likely to affect young people, women, ethnic minorities and migrants as well as lowereducated individuals (see also Yerkes 2011). 
This number is slightly higher than in the previous analyses due to missing data on occupational disability and work-life balance arrangements.

4 It should be noted that industry-wide agreements cover, on average, more employees than company agreements, but the data have not been weighted to account for this difference. If we were to focus on the share of employees covered, we would lose nearly one third of the data due to missing information. We have information on 8030 collective agreements and information on the number of employees for 5940 collective agreements. The number of employees covered by a collective agreement in our database ranges between 60 ( $10^{\text {th }}$ percentile) and 8600 employees $\left(90^{\text {th }}\right.$ percentile).

5 However, collective labour agreements, while in theory capable of providing social risk protection, are instruments outlining the rules of the game. The implementation of arrangements agreed upon within a collective labour agreement is largely dependent upon managers and/or organisational HRM policy (Yerkes 2011). How this implementation, or lack thereof, affects social risk protection, is an issue we leave for further research.

\section{References}

Aarts, Leo, Philip de Jong, and Romke van der Veen. 2002. Met de beste bedoelingen. WAO: 1975-1999, trends, onderzoek en beleid. 's Gravenhage: Elsevier.

Avdagic, Sabina. 2006. "One Path or Several? Understanding the varied development of tripartism in new European capitalisms.” Max Planck Institute for the Study of Societies, Cologne.

Baccaro, Lucio. 2003. "What is Alive and What is Dead in the Theory of Corporatism". British Journal of Industrial Relations 41: 683-706.

Baccaro, Lucio and Marco Simoni. 2008. "Policy Concertation in Europe: Understanding Government Choice." Comparative Political Studies 41: 1323-1348.

Bamber, Greg, Russell D. Lansbury, and Nick Wailes. 2004. International and comparative employment relations: globalisation and the developed market economies. London; Thousand Oaks, Calif.: SAGE.

Berger, Suzanne. 1981. "Organizing Interests in Western Europe: pluralism, corporatism and the transformation of politics." Cambridge and New York: Cambridge University Press.

Bonoli, Giuliano. 2005. "The Politics of the New Social Policies: Providing Coverage against New Social Risks in Mature Welfare States." Policy and Politics 33: 431-449. 
- 2007. "Time Matters: Postindustrialization, New Social Risks, and Welfare State Adaptation in Advanced Industrial Democracies." Comparative Political Studies 40: 495-520.

Boyne, George, Glenville Jenkins, and Michael Pools. 1999. "Human resource management in the public and private sectors: An empirical comparison." Public Administration 77: 407-420.

Brandl, Bernd and Franz Traxler. 2005. "Industrial Relations, Social Pacts and Welfare Expenditures: A Cross-national Comparison." British Journal of Industrial Relations 43: 635-658.

Budd, John W. and Karen Mumford. 2004. "Trade Unions and FamilyFriendly Policies in Britain." Industrial \& Labor Relations Review 57: 204-222.

Ebbinghaus, Bernhard and Anke Hassel. 200o. "Striking deals: concertation in the reform of continental European welfare states." Journal of European Public Policy 7: 44-63.

Esping-Andersen, Gøsta. 1990. The Three Worlds of Welfare Capitalism. Cambridge (UK): Polity Press.

- 1999. Social Foundations of Postindustrial Economies. Oxford: Oxford University Press.

- 2002. Why we need a new welfare state. New York: Oxford University Press. Giddens, Anthony. 1998. The third way: the renewal of social democracy. Cambridge: Polity Press.

Goldthorpe, John Harry. 1984. Order and Conflict in Contemporary Capitalism. Oxford: Clarendon Press.

Heywood, John and Uwe Jirjahn. 2009. "Family-friendly Practices and Worker Representation in Germany." Industrial Relations 48: 121-145.

Katz, Harry C. 1993. "The Decentralization of Collective Bargaining: A Literature Review and Comparative Analysis." Industrial and Labor Relations Review 47: 3-22.

Mailand, Mikkel. 2007. "Explaining variations in tripartism - the role of social partners in regulating work and welfare." Employment Relations Research Centre (FAOS), University of Copenhagen.

Nagelkerke, Ad and Willem de Nijs. 2003. "Sturen in het laagland." Delft: Eburon.

OECD. 1994. "OECD Employment Outlook." OECD, Paris.

Rein, Martin. 1982. "The Social Policy of the Firm." Policy Sciences 14: 117-135.

Rojer, Maurice. 2002. "De betekenis van de CAO en het algemeen verbindend verklaren van CAO's." Ministerie van Sociale Zaken en Werkgelegenheid (Ministry of Social Affairs and Employment). 
Schils, Trudie and Hester Houwing. 2010. "Sectoral Variation in Collectively Agreed Employment Protection: Evidence from Dutch Flexicurity." European Journal of Industrial Relations 16(2): 137-152.

Schreuder, Kilian. 2008. "Trade Unions and the Work-family Balance." Doctorate Thesis, Sociology, University of Amsterdam, Amsterdam.

Schreuder, Kilian and Kea Tijdens. 2004. "Codebook DUCADAM Dataset: een statistisch bestand van de FNV CAO-databank." Amsterdam Institute for Advanced Labour Studies (University of Amsterdam), Amsterdam.

SCP. 2006. "Emancipatiemonitor 2006." Sociaal Cultureel Planbureau, The Hague.

Siegel, Nico A. 2005. 'Social Pacts Revisited: 'Competitive Concertation' and Complex Causality in Negotiated Welfare State Reforms." European Journal of Industrial Relations 11: 107-126.

Taylor-Gooby, Peter. 2004. New Risks, New Welfare. The Transformation of the European Welfare State. Oxford: Oxford University Press.

Tijdens, Kea and Saskia Lieon. 1993. Kinderopvang in Nederland. Organisatie en financiering. Utrecht: Jan van Arkel.

Trampusch, Christine. 2006. "Industrial relations and welfare states: the different dynamics of retrenchment in Germany and the Netherlands." Journal of European Social Policy 16: 121-133.

Traxler, Franz. 1999. "The state in industrial relations: A cross-national analysis of developments and socioeconomic effects." European Journal of Political Research 36: 55-85.

Traxler, Franz and Bernhard Kittel. 200o. "The Bargaining System and Performance: A Comparison of 18 OECD Countries." Comparative Political Studies 33: 1154-119o.

Van Klaveren, Maarten and Kea Tijdens. 2008. "Bargaining Issues in Europe: Comparing countries and industries." Brussels: ETUI/UvA-AIAS/WageIndicator.

Visser, Jelle. 2007. "De wankele evenwichten van het corporatisme." Beleid en Maatschappij 34: 6-22.

Visser, Jelle 2006. "Union Membership Statistics in 24 Countries." Monthly Labor Review 129: 38-49.

Vossen, Marieke and Mirjam Engelen. 2002. "Monitor Werkgeversbijdragen Kinderopvang (Monitor of Employers' Subsidy of Childcare)." Research voor Beleid (Research for Policy), Leiden.

Wallerstein, Michael, Miriam Golden, and Peter Lange. 1997. "Unions, Employers' Associations, and Wage-Setting Institutions in Northern and Central Europe, 1950-1992." Industrial and Labor Relations Review 50: 379-401. 
Yerkes, Mara. 2006. "What Women Want: Individual Preferences, Heterogeneous Patterns?” Doctorate Thesis, University of Amsterdam, Doctoral Dissertation, Amsterdam.

- 2009. "Part-time Work in the Dutch Welfare State: the ideal combination of work and care?" Policy and Politics 37: 535-552.

- 2011. Transforming the Dutch Welfare State: Social Risks and Corporatist Reform. Bristol: The Policy Press.

Yerkes, Mara and Jelle Visser. 2006. "Women's Preferences or Delineated Policies? The Development of part-time work in the Netherlands, the UK and Germany." Pp. 235-262 in Decent Working Time, New Trends, New Issues, edited by Jean Yves Boulin, Michel Lallement, Jon Messenger, and François Michon. Geneva: ILO.

Zagelmeyer, Stefan. 2007. "Determinants of Collective Bargaining Centralization: Evidence from British Establishment Data." Journal of Industrial Relations 49: 227-245. 



\title{
7 Changing Labour Policies of Transnational Corporations
}

\author{
The Decrease and Polarisation of Corporate Social \\ Responsibility
}

Johan Heilbron and Sander Quak

Social risks can be managed in different ways. The management of social risks is commonly discussed in relationship to welfare state institutions or, in a less common approach, in relation to the protection corporatist institutions provide through collective bargaining, as presented in the previous chapter. However, one of the central institutions active in risk management, alongside the family, is the firm. In the nineteenth and twentieth centuries, firms took (some) responsibility for the well-being of their employees. In some welfare states, for example in the US, firms still play an important role in managing social risks, hence the term 'corporate welfare state, sometimes used to describe the US welfare state.

In this chapter we focus on the essential function private corporations fulfil in the way social risks are defined and dealt with collectively. It is important to investigate the role of private corporations in the management of social risks because firms become increasingly important in an era of economic globalisation. As markets open up and national states weaken, private corporations have more freedom to act. As companies become geographically and institutionally 'footloose', a process in the direction of reduced protection takes place, often called a 'race to the bottom' (Mishra 1999; Castles 2004) in the direction of diminished corporate responsibility for employees, resulting in a shift of responsibilities from employers to employees (Hacker 2006).

In this chapter, we investigate the development of labour policies in two transnational corporations. We learn that due to the fact that these corporations are embedded in different national and transnational economic fields, the extent to which corporate responsibility for protection against social risks is diminishing varies from risk to risk, and that a polarisation is taking place in corporate responsibility between the responsibility taken for higher management and responsibility taken for lower levels of personnel. 
Because the role of large firms has been unduly neglected in many debates about the transformation of the welfare state, in this chapter we will explore the changes large corporations have gone through since the 198 os and assess some of the consequences these have had for the redefinition and redistribution of social risks. We will do so by considering the profound transformation in the way corporations managed their labour force during the last two decades of the twentieth century. The most simple and straightforward description of this transformation is that it has shifted from 'personnel administration,' carried out in primarily national settings, to a more transnational mode of 'human resource management'. Our approach to this change differs from the standard economic analysis in which firms are seen as isolated actors that pursue their objectives independent of their relations to other actors. In contrast to such a view, our analysis is centred on the way in which firms are embedded in the context in which they operate. The various modes of embeddedness can be conceived in terms of field dynamics, in the sense that Bourdieu (2005) and Fligstein (2001) have given to the concept. Economic actors are embedded in field structures, which define the constraints as well as the opportunities these actors confront. Such a field approach simultaneously allows a reformulation of the issue of globalisation. Contrary to the idea that globalisation leads to a practically unrestricted freedom for corporations, in the field approach, globalisation can be conceptualised as a process of shifting dependencies on national and transnational fields. Large firms continue to operate within the borders of national states and as such remain dependent on a variety of local and national institutional arrangements, but they have indeed become significantly more dependent on transnational fields. In the present chapter we examine the consequences of this shift in dependencies for corporate labour policy.

First, we will argue that a field approach is a fruitful way to understand how firms and their business strategies evolve. After elaborating what this approach entails, we will highlight the most salient changes occurring in transnational corporations since the economic crisis of the late 1970 s and early 1980 s, and specify what the consequences have been for corporate labour policy. We will, in particular, argue that the rise and spread of 'human resource management' can be understood as part of the strategic reorientation of firms towards enhancing 'shareholder value'. In the second part of this chapter we will consider how these changes have played out in the case of two large and originally Dutch firms: the high-tech firm 
Philips and the financial corporation ING. Here we will, in particular, examine how a balance is struck between the policies of 'international human resource management' and the continuous dependence on national institutional arrangements. In the conclusion, we reflect on the expectations derived from the presented approach and we will summarise the main consequences of the shift from 'national personnel administration' to 'transnational human resource management' in terms of labour policies and the management of social risks.

\section{Dual embeddedness and its consequences}

Following one of the basic principles of (economic) sociology, corporations and the policies they pursue need to be understood as being embedded in sets of ongoing social relations (Granovetter 1985; Convert and Heilbron 2007). These social relations can be conceptualised as fields, as defined by Pierre Bourdieu and Neil Fligstein. Bourdieu conceived of fields as relatively autonomous social spaces in which actors compete for specific stakes. The relations between these actors are defined by the position they occupy in the field, and by the corresponding volume and composition of capital they dispose of. Besides the usual forms of economic and financial capital, firms also mobilise other forms of capital, especially technological, social and symbolic capital (Bourdieu 2005). Building on Bourdieu's field theory and insights from organisational theory, Fligstein has proposed an analysis of North American corporations and their development since the late nineteenth century (Fligstein 1990). In this section, we take up Fligstein's analysis of corporations in the United States (US), reformulate it in order to account for the increasing globalisation of firms, and then propose a number of expectations to explore empirically for the Dutch case in the second part of this chapter.

Central to Fligstein's field approach is the idea that actors make decisions under conditions of uncertainty (Fligstein 2001). Given the uncertainties of action and its consequences, corporations primarily strive to maintain a stable position in the field in which they operate. Price competition and internal power struggles are the two most important threats to this stability, therefore, firms are in need of a strategic orientation that allows them to deal with these potential threats. As a result, firms rely on a certain 'conception of control' in their strategic decision making. Such a conception provides a vision of how to make the firm work internally and externally, in terms of how the firm interacts with its main competitors. 
Historically, different conceptions of control have succeeded one another, each one of them related to structural changes in the economic field and the conditions under which it operates (Fligstein 1990). In addition, the competition between firms is regulated by the state, which assures property rights and defines rules for economic exchange and proper governance.

In his analysis of US corporations, Fligstein has argued that the dominant strategy of US corporations since the 1970 os and 1980 os has been centred on creating 'shareholder value.' Firms are no longer seen as diversified conglomerates that have to manage their relationships with a plurality of both stake and shareholders. In contrast, the conception of shareholder value has redefined the firm as a bundle of assets that managers deploy and redeploy in order to maximise the return for its shareholders (Fligstein 2001, Heilbron 2005). The shift from a managerial to a shareholder value perspective has taken place in a political context of deregulation and increasing internationalisation. As a consequence, companies have increasingly been forced to cope with what we call dual embeddedness: they are no longer primarily embedded in the national field of their home country, but are increasingly embedded in a transnational field as well. This transnational field is in a state of flux regarding specific rules and regulations that govern firms, both formally and informally, and has thus become a major source of change for transnational corporations.

A number of expectations may be formulated about the development of corporate labour policy using these insights. In order to stabilise or improve their position within the emerging transnational field, corporations have adjusted their strategy to its competitive requirements, and corporate policies may be expected to have undergone a certain degree of interor transnationalisation. Firms can be expected to have extended an overall corporate policy to be implemented by firm subsidiaries, regardless of their specific local circumstances and national context (first expectation). However, in comparison to other domains of corporate policy, such as production, finance and marketing, labour policies have continued to remain strongly dependent on institutional arrangements at the local and national level (local collective bargaining, national labour legislation, collective labour agreements, consultative bodies). Therefore, it seems likely that the transnationalisation of corporate labour policy is more limited than the transnationalisation of corporate policy in other domains (production, finance and marketing), thus resulting in a limited degree of convergence and continuing path dependency. Labour policy continues to be shaped by institutional differences across sectors and countries (second 
expectation). The predominant way in which corporations deal with this dual embeddedness is by a) outsourcing production facilities to low-wage countries; and b) differentiating their labour policy. On the one hand, firms' labour policy is likely to contain a centralised transnational component, which specifically pertains to higher management and its international circulation (selection, training and performance). On the other hand, firms' labour policy is likely to be made up of multiple national policies, aimed primarily at lower levels of company personnel (third expectation). Yet not all parts of corporate labour policy are equally dependent on national and local arrangements. It can therefore be expected that different parts will display various degrees of transnationalisation, with the department responsible for human resource management being the most transnational in character, followed by mobility policy, employee participation and rewards (fourth expectation). Finally, we expect that this dual embeddedness has provided firms with a rhetorical means to shift certain costs (such as unemployment insurance, health insurance, pension premiums) from the firm level to other parties, in particular to individual employees (fifth expectation).

\section{US corporations and the shareholder value conception of the firm}

After almost three decades of high and relatively stable economic growth, transnational corporations faced a severe economic downturn during the latter half of the 1970s and the beginning of the 1980s (Van Zanden 1997, Brenner 1998). North American firms in particular saw their profitability decline due to growing competition from Japanese competitors and the combined effect of slow economic growth and high inflation ('stagflation'). American corporations lost market shares in a number of industries, such as consumer electronics and cars, and high inflation simultaneously led investors to shift away from company stocks to government bonds, causing share prices to fall even further. These economic difficulties were reinforced by uncertainties in the international economy caused by the collapse of the Bretton Woods agreement (outlining fixed exchange rates) in 1971, and by the international oil crises of 1973 and 1979.

The initial response to the economic downturn was defensive: managers cut costs, attempted to enhance efficiency, and some ventured to obtain state support through subsidies, tax advantages, and protective measures. When the crisis turned out to be longer-lasting and deeper than any previous recession since the end of World War II, vivid debates emerged 
about the need for structural reform. For example, Japanese management styles gained considerable interest for a short while. Eventually, however, the business strategy that triumphed over all others was that corporations should henceforth be managed for the purpose of creating 'shareholder value.' The predominant management conception after WWII relied on managing trade-offs between different stakeholders. Shareholder value, in contrast, envisions that corporate executives should act in the interests of shareholders, and of shareholders only, thus ensuring that the firms' resources return the highest possible profits to their owners. This idea of 'maximising shareholder value' emerged around 1980, and was initially advocated by relative outsiders to the business establishment, namely corporate 'raiders' (Heilbron et al. 2011). Several corporate raiders made their fortune in the oil industry during the years of the oil crises, and their considerable financial resources allowed them to buy portions of stock in undervalued companies with the aim of restructuring them and rapidly reselling them, whether in parts or as a whole. Raiders like T. Boone Pickens were actively involved in the founding of the United Shareholders Association (1986) - characteristically abbreviated as USA - which was one of the first organisations to systematically oppose the creation of shareholder value to the perceived failings of management.

Although the focus on shareholder value was initially resisted by many executives, the wave of 'hostile' takeovers in the beginning of the 1980s, together with other forms of pressure from activist shareholders, forced management to adapt to this new balance of power (Useem 1993). The decisive factor in this change was the unprecedented power of institutional investors (pension funds, mutual funds and insurance companies). These investors had gradually accumulated increasing portions of shares in publicly traded companies and organised themselves in the Council of Institutional Investors (1985), which collectively promoted the shareholder value conception of the firm. The collectivisation of stock ownership and the new shareholder value tactics of small pressure groups of activist investors thus led to a shift from managerial to shareholder capitalism (Useem 1996, Fligstein 2001). With their large sums of capital and their financial expertise, institutional investors became a crucially important group for management to take into account. Institutional investors, for example, financed a sizeable proportion of takeovers during the 1980s (Baker and Smith 1998: 224). Unlike the more cautious company pension funds, civil servants' pension funds were among the first to adopt a critical and activist stance with regard to management. The teachers' 
pension fund in California (CalPERS), for example, set up the Council of Institutional Investors, which coordinated the action of major shareholders (Davis and Thompson 1994). They promoted a business orientation consistently based on pursuing shareholders' interests in publications, at shareholder meetings, and in regular consultations with managers. These activists sought a refocusing of corporate policy towards measures that would increase stock prices. Measures taken to increase stock prices included a refocusing of the firm towards the 'core business' and selling or outsourcing other business ventures, improving transparency about the company's strategy, raising dividends, introducing stock buy-backs, and considering mergers and takeovers. Companies that underperformed in these respects saw their share prices fall, thus increasing their vulnerability of being targeted for a takeover.

The increased dependency on investors and the stock market not only forced management to adapt to the new balance of power and to implement shareholder value tactics it simultaneously allowed management to secure better compensation packages for themselves. These compensation packages regularly included provisions for 'golden parachutes' in the event of dismissal, and together with share, option and bonus plans became standard elements in executive contracts. With compensation directly related to the perceived interests of shareholders, increasing 'shareholder value' became the primary objective. Strategies advocated by the proponents of shareholder value were widely implemented throughout the US in the course of the 1980 os and 1990s. A clear indicator of this change is the fact that while the proportion of company profits paid out to shareholders had been decreasing for more than fifty years, US corporations paid higher dividends and reserved less for investment during the 1980 and 1990s (O'Sullivan 2000: 192).

An analysis of the American business media of this period (Heilbron et al. 2011) suggests that the shareholder value conception of the firm spread during the first half of the 1980 os and became dominant during the second half of that decade, when corporate raiders were joined by various other groups in advocating the sovereignty of shareholder interests (institutional investors, merchant banks, consultants). In comparison to similar reports in the British business media, the concept of shareholder value became dominant in the United Kingdom during the first half of the 1990 s, whereas in the Netherlands this seems to have been achieved only in the second half of the 1990 os. 


\section{Corporate labour policy during the era of shareholder value}

Parallel to the strategic reorientation of US corporations towards shareholder value, corporate labour policies underwent a related shift from 'personnel administration' to 'human resource management'. This change represented both a change in terminology, which occurred during the 1980 s, and a shift from an 'administrative' to a 'managerial' perspective in labour policy. The latter indicated a centralisation of labour policy, in which employee issues were more explicitly tied to the strategic objectives of the firm. This centralisation implied a redefinition of tasks. Managing personnel was no longer seen as an activity that took place outside of, or in addition to, the economic objectives of the firm. Rather, it became an integral part of the firm's central objectives. Managing the workforce was no longer relegated to specialists in 'human relations', but was reconceptualised as being fundamentally similar to other managerial tasks. In addition, managing employees was now seen as a question of making optimal use of one of the firm's resources. From this perspective, human resources are subject to investment and disinvestment decisions, just as physical and financial resources are, all of which are derived from the firm's central objective: to enhance shareholder value.

The major contributions to this new conception were developed in rapidly expanding business schools. In one of the founding statements of the new approach, it was typically argued that corporations need a 'reason for being' (mission) and a policy of how to display 'materials, information and people to carry it out' (Devanna et al. 1984). This strategic perspective regarding the proper use of (human) resources was a considerable change from more traditional labour policies. For most of the twentieth century, 'personnel administration' had been focused on 'human relations.' This approach was shaped intellectually in a rather eclectic fashion by contributions from psychologists, sociologists and organisation theorists (Kaufman 2000 and 2007, Jacoby 2005: 78-100) and not by economics or economic and financial models of doing business. In other words, there was no consistent intellectual approach to personnel management within US firms, and it had no professional identity comparable to that of economists, engineers or accountants. The economic idiom of 'resource management' provided at least a rhetorical unification of management practice. This unification, which occurred in the broader context of neoliberal politics of the $198 \mathrm{os}$, was more specifically marked by the attempts of neo-classical economists to incorporate an ever expanding number of areas into their micro-economic framework of utility maximisation. Ap- 
plied to firms, this led to a theory of the firm ('agency theory') in which maximising shareholder value was considered to be the general objective of corporations, and the labour force was considered to be nothing but a means to that end (Whitley 1986, Fourcade and Khurana, forthcoming).

The centralisation of corporate labour policy that occurred is well indicated by the fact that by the year 2000, human resources managers in US firms reported directly to the CEO far more often than two decades earlier (Jacoby 2005: 132). It did not imply, however, that personnel management had obtained a higher status in corporate affairs. Quite the contrary. While being more directly submitted to the imperatives of corporate strategy, human resource departments shrank in size and generally lost influence (Jacoby 2005: 91-95). Declining union membership, corporate downsizing and tighter alignment with Wall Street forced human resource managers to translate the focus on shareholder value strategy into labour policies that were designed to maximise benefits and minimise costs.

Despite some variation by industry and firm, aggregate outcomes of shareholder value strategies for the US show a consistent pattern. While it is still a matter of dispute whether productivity and profitability have increased (for critical views see Baumol et al. 2003, Fligstein and Shin 2007), consequences of new corporate labour policies show a clear pattern of polarisation. While the upper levels of the corporate labour force have improved their position, for example through considerable raises in salary, special programmes and other benefits (including bonus, option and stock programmes), the position of middle and lower level employees has degraded. Due to the joint effect of corporate strategies and state policies (Soss et al. 2007), inequality in income and wealth has become significantly larger in the US and in other advanced economies since 1980 (Wilterdink 1995, Atkinson \& Piketty 2010). Employee benefits have generally been reduced and, in some cases, abolished. For example, the percentage of American firms that provide fully-financed health insurance to their employees declined from 56 percent in 1988 to 37 percent in 1996 (Quadagno 1999). The proportion of workers covered by a pension plan has declined, and instead of so-called 'defined benefit plans' promising fixed retirement payments, employees are now commonly covered by 'defined contribution' plans, thus shifting the risk and responsibility from employers to employees (Hacker 2006, Ghilarducci 2008). At the same time, the number of career jobs available within firms is smaller than it was before, the proportion of contingent employees (part-time, temporary and contract workers) has increased, and job security has declined (Hacker, 2006). 
With the balance of power shifting from managers to investors, both the shareholder value conception of the firm and the redefinition of personnel management as human resource management spread rapidly throughout the economic field in the US. In 1989, the American Society of Personnel Administrators (ASPA) changed its name to the Society for Human Resource Management (SHRM). At about the same time, after the fall of the Berlin wall in 1989 and the collapse of communism in Eastern Europe, leaving the US as the only superpower, these new American business practices spread to other countries as well. Characteristically, the expression 'International Human Resource Management' was coined around 1990, the first conference on International HRM was held at the same time, and the leading professional journal, the International Journal of HRM, was established in 1991 (Bjorkman \& Stahl 2006: 1-2). While the international spread of human resource management represents an unmistakable shift in meaning, its actual significance depends on the ways in which it has effectively been incorporated into national and local settings. In order to examine this process of diffusion and adaptation, we will compare the changing labour policies of two large, originally Dutch corporations: Philips and ING.

\section{The making of transnational firms: the cases of Philips and ING}

During the past three decades, many large corporations have become increasingly dependent upon the transnational field and have experienced a strategic reorientation towards enhancing shareholder value. At the same time, these developments have played out differently for various companies based on their individual historical background, sector-level differences and national context. From the 1980s onwards, both Philips and ING have become more transnational corporations; both have implemented a transnational organisational structure as well as transnational policies and strategies. However, although both companies have developed in a similar direction, the timing, implementation and consequences of these changes display significant differences. The following description of these two companies is the result of interviews with employees of both organisations and a document analysis conducted as part of dissertation research by the second author (Quak, forthcoming).

Philips was founded at the end of the nineteenth century in the Eindhoven region in the southern part of the Netherlands as a producer of light bulbs. In its first years, Philips was quick to compete with foreign 
producers by exporting its products around the globe. During the first few decades of the twentieth century, Philips expanded both its product range, turning it into a producer of electronic equipment, as well as its foreign subsidiaries, thus increasing the number of employees both at home and abroad. But Philips was still primarily embedded in the Eindhoven region. When national governments started to intervene in the international economy following the Great Depression and WWII, Philips adopted a local-for-local strategy, with its factories around the globe producing for their individual local markets, and presented itself as a local producer.

In the first three decades following WWII, Philips quickly expanded its operations, competing with a relatively small number of other producers of electronic equipment for a dominant position within these fields. Philips grew to become an industrial conglomerate with 400,00o employees across the globe and consequently, was now embedded in a plurality of national fields. Despite this international growth, the Netherlands remained Philips' centre of gravity. One quarter of its employees was still located in the Netherlands, and corporate headquarters as well as division head offices were located in the Netherlands. In addition, its management consisted of primarily Dutch nationals.

By the 1970 os and 1980 os, however, the deregulation of international trade in reaction to the economic crises of the 1970 caused an increase of competition from foreign producers. Philips was no exception and experienced the full force of the rise of primarily Japanese companies during this period. Moreover, national economic fields began integrating into a transnational economic field. Over the course of the 1970s and 1980s, these developments caused Philips' profit margins to decline slowly and by the end of the 1980s, Philips stood on the edge of bankruptcy. In response to this development, Philips began a large scale restructuring programme, consisting of the centralisation of its production capacity, the outsourcing of significant parts of the production process, the focus on a select number of product markets, the transnational reorganisation of its company structure and an increased focus on financial criteria.

During this same period, Philips was already experiencing the consequences of operating in an increasingly competitive, transnational field. In an attempt to improve efficiency and sustain its dominant position, Philips suspended its local-for-local production strategy and began centralising its production capacity. This process was started in the 1970 s but still continues today. In addition, Philips was initially seen as the 'embodiment of the age of mass production' (Sluyterman 2005: 129) during the first decades following WWII because of its clear integration both verti- 
cally and horizontally. But by the 1970 and 1980 os, it became clear that in a time of increasing competition, Philips had to focus on what it did best. Many non-core activities, such as catering and security, as well as some core activities, such as parts of the production process, were transferred to external suppliers or outsourced to low-cost countries. When Philips announced a large scale restructuring plan in 1990, this plan included not only a scaling back of 45,000 employees (from a total of 280 ,000), but the plan also proposed a focus on a select number of products. In the highly competitive, transnational, electronics field, Philips was not able to compete in all product markets. Following various acquisitions and divestments during the 1990s, Philips decided to focus on lighting, consumer electronics and healthcare. Also, as noted above, Philips suspended its local-for-local strategy and instead introduced a transnational structure, including the implied transfer of responsibility for all marketing and production decisions to transnational divisions. The transfer of power from the national to the transnational level is further illustrated by the fact that these transnational divisions and business units were given profit and loss responsibility. The transnationalisation of Philips continued during the 1990s, resulting in an increasing number of non-Dutch nationals being appointed to executive positions.

Finally, during the past two decades, Philips has increasingly focused on financial criteria, especially shareholder value, as a way of governing and controlling the company. Financial criteria had gained in importance by the late $198 \mathrm{os}$, but it was not until the second half of the 199os, when Philips had the first-ever CEO recruited from outside the company, that shareholder value became a dominant business principle. By that time, Philips no longer compared itself to other producers of electronic equipment; rather, it now compiled a list of companies for benchmarking purposes, consisting of large corporations that were perceived to be generating large financial returns for their shareholders. Subsequently, instead of having national organisations making rather autonomous production and marketing decisions, Philips centralised these decisions to the transnational level during the 1990 os and 2ooos. Decisions about which products Philips will focus on, which consumers it tries to target, which distribution channels it will use, how the company positions itself vis-à-vis its competitors, and how Philips wants to position its brand, are now all taken by managers with transnational responsibilities. Moreover, these decisions are all made in the context of improving shareholder value in order to survive. In sum, throughout the past three decades, Philips, a large production company in the Netherlands, has becoming increasingly 
transnational, reorganised its production capacity in line with the conditions of the emerging transnational economic field, and increasingly focuses on shareholder value as its dominant business principle.

Our second case study focuses on ING, a financial company in the Netherlands. Financial companies were generally much smaller than production companies. But in anticipation of the integration of Europe's financial markets in 1992, the Dutch financial sector was characterised by a merger wave at the end of the 1980 os and the beginning of the 1990s. Banks and insurers merged or collaborated to form corporations that offered all possible financial services to all potential clients via all possible distribution channels in the Netherlands, and later also abroad, a financial services concept often called all finance. One of the companies to come out of this merger wave was ING, a financial giant which would become the largest financial corporation in the world by the mid-2ooos. ING is the result of a merger between the formerly state-owned Postbank, the NMB Bank, and the insurance company Nationale Nederlanden. Postbank itself was the result of a merger between two state-owned banks, which were established by the Dutch government at the end of the nineteenth and beginning of the twentieth century to create a nation-wide system of guaranteed cheques as well as to give every Dutch citizen the possibility of opening a savings account. The NMB Bank was founded at the beginning of the twentieth century and primarily focused on providing credit to small and medium-sized businesses. Nationale Nederlanden was the result of a merger in the 1960 os between the then two largest Dutch insurers and offered both insurance as well as some banking products, such as mortgages.

The large merger leading to ING was not immediate. First, in 1989, in an attempt to increase their market share and be able to offer financial services to a larger target group, the Postbank and NMB Bank merged to form the NMB Postbank Group. At the time of this merger, both banks were Dutch firms. As a result of its previous status as a state-owned company, Postbank was legally bound to the Dutch market and employed around 11,0oo people, all in the Netherlands. In contrast, NMB Bank already had international aspirations by the mid-1970s, but by 1988, 90 per cent of its almost 12,00o employees were still employed in the Netherlands. The insurance company Nationale Nederlanden had similar international aspirations, but was more successful in achieving these than NMB bank. In the two decades prior to the merger between NMB Postbank Group and Nationale Nederlanden in 1991, Nationale Nederlanden had increased its international activities through a range of acquisitions. In 1972, almost 80 
per cent of its employees were employed in the Netherlands, but this proportion had dropped to 40 per cent by the time of the merger in 1991. As a result, when ING was formed, almost two-thirds of its personnel were employed in the Netherlands.

ING was primarily engaged with the integration of its three Dutch subsidiaries during the first three years after its founding, but from 1995 onwards it began a rapid process of internationalisation. As a result of bank acquisitions in the United Kingdom, Belgium, Germany, Eastern Europe and Turkey as well as insurance companies in North and South America, ING grew from 50,00o employees in 1991 to more than 120,000 employees in 2008. ING's international ambitions and expansion are best illustrated by the fact that during these years, the number of employees in the Netherlands remained around 30,000, ${ }^{1}$ whereas the number of foreign employees at ING expanded from 18,00o in 1991 to around 95,00o in 2008. ING's increasing presence in the transnational financial field is also reflected by the transnationalisation of its revenues. In 1991, more than 60 per cent of ING's revenues was earned in the Netherlands; by 2008 , this had dropped to around 20 per cent. In addition, the geographical distribution of its outstanding shares shifted: in 2008 , only 20 per cent of ING's shares was owned by Dutch individuals or organisations; at the end of the $1990 \mathrm{os}$, this was almost 50 per cent. Moreover, as was the case with Philips, ING also experienced the transnationalisation of its executive and supervisory board.

With the transnational expansion of the company during the late 1990 s and 2000 s ING became restructured in line with the transnational field in which it had become embedded. Regional (European, American and Asian) and transnational structures were implemented to reflect changes in the organisational environment and responsibilities and power to make decisions were transferred to these levels. And even though it was relatively minor in comparison to Philips, ING also outsourced some parts of the company, such as the mail department, for cost efficiency.

Resembling the development at Philips, shareholder value became increasingly dominant at ING during the 20oos. The transition to shareholder value was evident by the end of the 1990s, when the term 'embedded value' was introduced, a concept used within ING to measure the value of the organisation, which allows management to focus on maximising value within risk parameters. In addition, from 2000 onwards, shareholder value obtained an increasingly prominent place in ING's annual report. ING's financial results increasingly became specified in terms of how much ING's shareholder value had grown. In short, enhancing share- 
holder value became the central concern of ING during the mid-20oos; an 'American wind of change' was clearly observable.

In sum, like Philips, ING has restructured itself towards the transnational level, even though it can be argued that the transnationalisation of ING was of a slightly lesser degree and slightly later. On the one hand, strategic corporate decisions are now made by managers with transnational responsibilities. ING has also started to promote its brand around the globe during this past decade. But on the other hand, ING is inherently national because it provides services, and is therefore unable to relocate 'production capacity' abroad. In other words, there has not been a transnationalisation of production decisions on the same scale as we have seen with the case of Philips. Also, even though ING's individual subsidiaries around the globe have been placed under division management, some of these divisions have only a regional role (e.g. Europe). Given that financial products continue to differ across the globe, individual subsidiaries have a much greater degree of autonomy.

\section{Managing personnel in transnational firms}

In the previous section, we have shown that although the exact timing and the degree to which transnationalisation has taken place differs among our case studies, both Philips and ING have experienced a transnational restructuring of their organisation since the 1980s. In this section, we will now investigate what the consequences of this development are for their corporate labour policy, focusing specifically on the organisational structure of the human resources (HR) department, employee participation, mobility, and rewards. We expect labour policies to be affected differently by transnationalisation. The more labour policy is influenced by national fields, the less transnationalised it will be, and vice versa. This will result in a differentiation or even polarisation of labour relations, with large differences between higher and lower level company personnel, and in a shift of responsibilities from the firm level to individual employees.

\subsection{Human Resources Department}

As a result of the rapid decrease in the number of employees in the Netherlands during the 1990 os and 20oos, the HR department of the Dutch subsidiary of Philips significantly decreased in size. In addition, with the integration of the entire Philips organisation into 'One Philips', an pro- 
gramme which was set up to integrate Philips' various subsidiaries around the globe, there has been a centralisation of tasks and responsibilities to the transnational level as well. With regard to their labour policies, these developments mean that the transnational corporate HR department centralised tasks previously conducted at the national level, by national HR departments. In recent years, so-called central competence centres have been created to deal with talent management, expatriation, performance management and rewards. Whereas the corporate HR department was previously primarily engaged with HR policies for the top of the organisation, during this past decade it began developing policies for a larger percentage of Philips' total work force. The corporate HR department has not only developed its own transnational policies, it has steered the development of Philips' various national HR departments as well. The corporate HR department has developed a human resources model, which serves as a framework for national HR departments and their restructuring. This framework is evident, for example, in the Dutch HR department, where all transactional functions have been grouped into a shared service centre. Moreover, all recruitment activities of the various sectors and business units in the Netherlands have been centralised into the national HR department. This human resources model can be conceived of as a service delivery model.

ING's personnel department experienced a similar development. The personnel departments of two of ING's predecessors, the Postbank and Nationale Nederlanden, were referred to as Social Affairs (Sociale Zaken). In their annual report, these departments present themselves as organisations that take good care of their employees, and in return, their employees display a great deal of loyalty; words such as 'individuals' and 'people' are used often. A slight change in language took place during the 1980 s. Social Affairs became 'Personnel affairs' and later, 'Personnel and Organisation. The departments also began to refer to the 'human potential' of the organisation. For example, during the 1970s, ING's other predecessor NMB published the average cost per employee in its annual social report. By 1983 , this figure was accompanied by the average value added per employee. Then later during the 1980s, the position of labour underwent a dramatic shift from individuals who are taken care of by their employer to the human potential of the organisation, which is deployed and redeployed by the organisation in a way that is most beneficial to the organisation. At the end of the 1980 s and beginning of the 1990 os this development was accompanied by a strong call for the flexibility of employees, employees were expected to help ING quickly adapt to changes in the economic 
environment, for example by being mobile. When ING was formed at the beginning of the 1990s, the changed direction in human resource management was still evident. First, the personnel department was renamed Personnel and Organisation. Also, ING tried to integrate the personnel departments of its predecessors, but it took until the 2000 s before this really took place. In the year 200o, the personnel department was once again renamed, this time it became HR Netherlands. At first glance, this change can be understood in the context of an internationalising firm, whose corporate language changed from the native Dutch language to English. But this name change was accompanied by a more fundamental change in the role of the human resources department within the organisation, namely from an administrative organisation which took care of the employees into a strategic business partner to company management. This change was accompanied by a reduction in the number of employees working in this department. Prior to this shift in 2000 , ING maintained a ratio of approximately one personnel employee for every 30 employees working at ING in the Netherlands. However, in the beginning of the 200os, ING conducted an international benchmark, both internally and externally, and discovered that this ratio was relatively high. This discovery led to a restructuring of the personnel department. ING not only reduced the number of employees working in the HR department, creating a ratio of $1 \mathrm{HR}$ employee to 50 , administrative tasks were now standardised and computerised and the HR department was also given an advisory role. Rather than being responsible for the initiation and implementation of labour policies, the administration of the work force and safeguarding the interests of employees within the organisation, HR became primarily concerned with advising line management in relation to the work force. In short, its role shifted from servicing employees into servicing management.

A new element in the organisational structure of ING closely related to the transnationalisation of the firm was the establishment of a transnational HR department in 200o. In the first years after its foundation, this department was primarily concerned with talent management and attempting to install a global personnel administration system. With the new transnational structure of the organisation in 2004, staff departments at the corporate, transnational level considerably increased in size and the corporate HR department was no exception to this. Besides talent management they became concerned with management development, executive pay, international mobility, governance and operations (global HR systems). Corporate HR and the newly installed HR departments of the global business lines began developing global guidelines and frameworks 
for the local and national HR departments. The development of its HR department is in line with ING's overall development.

\subsection{Employee participation}

Employee participation at work is institutionalised in the Netherlands, through the use of works councils. Philips and ING are no exception to this institutionalisation and both companies have installed various works councils at different levels within their organisations to facilitate discussions between management and employees in the Netherlands. With the transnational expansion of both companies, Philips and ING have also implemented a new legal structure. Prior to this change in structure, the executive board of each company was the main representative of the central works council. Following the new legal structure, the main representative is now the board of each company's Dutch subsidiary. Philips implemented this change in the beginning of the 1980 os when they separated the management of their Dutch subsidiaries from company management. At ING, however, this change took place in 2003, around the time that ING installed a new transnational organisational structure.

Works councils are not only institutionalised in the Dutch structure of employment, since the mid-199os the European Union has begun regulating their existence. The EU created a directive in the mid-1990s making the instalment of European works councils mandatory for companies with more than 1000 employees in two or more countries within the European Union. In response to this directive, both Philips and ING installed such a works council. However, while these works councils have regular meetings with the CEO and other executive board members, their position within the company remains weak. During the first few years of their existence, these European works councils were primarily a place where colleagues from different European countries met and discussed how things were done in their respective countries. But these 'European' works councils struggled as well, for example with language problems - not all members spoke English, which turned these meetings into interpreter parties. Also, some members from Eastern European countries were appointed by local management rather than being elected by the employees, and not all members were always willing to come to meetings. Even now, the position of European works councils remains relatively weak compared to the position of the Dutch central works council. European works councils are regularly informed by the executive boards on strategic matters but they have no real say in company affairs. 


\subsection{Mobility}

As indicated above, HR departments have developed from administrative organisations, responsible for protecting employees' interests, into the business partners of company management. At the same time, Philips and ING operate within the context of a transnational field, one that requires companies to respond quickly to changes in this field, which means companies are constantly reinventing themselves to obtain and sustain a dominant. As a result of this development, the relationship between these companies and their employees has changed. Philips' and ING's employees have become responsible for the development of their own careers. The promise of lifetime employment has come to an end; employees are now expected to develop themselves in order to remain employable. This development has been stimulated by the foundation of mobility centres and the creation of an internal labour market. At the same time, given the increased embeddedness in a transnational field, we might expect that a transnationalisation of the labour force has occurred as well. But if we look at the work force composition at Philips and ING, we must conclude that this transnationalisation of the work force is limited to executive and specialist functions such as traders at ING and engineers at Philips.

\subsection{Rewards}

Rewards are an important component of corporate labour policy. In the Netherlands, many employees' working conditions are agreed upon in collective labour agreements, negotiated by company representatives and trade unions. Philips and ING are no exception and their reward systems remain strongly embedded in the Dutch economic field. But this does not imply that their employees have not experienced the consequences of the increasing transnational embeddedness of these companies. Both Philips and ING have introduced a performance management system to align the remuneration of their employees with the strategic goals of the firm. In order to be successful in the transnational field, these companies want all their employees to contribute to the strategic goals of the company. They stimulate their employees to do so through by introducing financial incentives. The targets used to determine financial incentives depend upon the position of the individual employee. Executive board members, for instance, are rewarded on the basis of how well the company does financially, but desk employees from the local office (ING) or factory workers (Philips) are rewarded based on individual or group targets. For the av- 
erage employee, performance-based rewards vary between one and two months salary, but for employees at higher levels these rewards can be upwards of a full year's pay or more. In short, rewards are still largely determined by collective bargaining negotiations between trade unions and the Dutch HR departments, but at the same time, the transnational, corporate HR departments have created guidelines to steer these negotiations.

One interesting part of a company's rewards system is pensions. Traditionally, pensions in the Netherlands are based on a defined benefits system, a system present at both Philips and ING. This means that when employees retire, they receive a fixed amount of their last salary, depending upon the number of years they have worked for the company. Traditionally this amount is increased every year to compensate for inflation. In order to ensure there is enough money to cover all pensions, companies pay pension premiums for their employees (a certain percentage of the salary), which goes to the pension fund to be invested. If these investments are very profitable, companies can reduce their monthly premiums, but if these returns are less profitable, companies have to compensate these losses. Doing so poses a risk to companies, a risk which investors do not appreciate when considering their investment decisions. For this reason, both Philips and ING are in the process of changing their pension system from a defined benefits system to a defined contribution system.

In sum, in the past three decades both Philips and ING have restructured various parts of their corporate labour policies on the transnational level, but differences between various parts and in timing can be distinguished. Where the HR department of both companies have experienced a certain degree of centralisation on the transnational level, Philips was the first to undertake this process, just as it was the first to restructure the company as a whole on the transnational level. Also at both companies, this restructuring also meant a change in the role of the HR department, from an administrative centre which also protected employees' interests into a business partner to company management. Also, both Philips as well as ING have altered their legal structures resulting in their Dutch works councils being disconnected from company management, and instead being linked to both companies' national boards, even though, again, Philips had this new structure in place two decades before ING. At both companies, employees themselves have become responsible for their career development. And finally, both companies have tried to align their reward systems with the strategic goals of the firm by implementing financial incentives and are in the process of transforming their pension systems. 


\section{Conclusion}

In the preceding analysis, we have focused on the changing embeddedness of firms in order to understand the development of corporate labour policy. We have shown, in particular, how a field approach can be used to understand the consequences of globalisation. Due to their international expansion, large firms increasingly experience a dual embeddedness; not only are they embedded in the national field of their home country, they increasingly operate in a transnational field as well. In order to gain access to or to improve their position in the transnational field, companies organise themselves in line with the structure and the constraints of this transnational field. This transnationalisation has resulted in the development and implementation of transnational policies in various domains, including the domain of labour policy (first expectation). Due to the continuing national embeddedness of labour, however, the transnationalisation of this part of the company's policy is more limited than in other primary domains (such as finance, production and marketing). Companies must comply with national legislation, negotiate with local or national trade unions and are, in countries such as the Netherlands, dependent upon the outcomes of consultations between trade union confederations, employers' organisations and the national government, which affects future developments of the local labour market (second expectation).

Changing corporate labour policies can be understood as a way of dealing with this dual embeddedness. To comply with the competitive conditions in the transnational field, they outsource parts of the company that can be handled more efficiently in low-cost countries. They simultaneously formulate common goals such as enhancing shareholder value and general frameworks like human resource management, which are then implemented at the different national levels. In addition to the centralised, transnational component, other dimensions of the labour policy are left to management at the national and local levels (third expectation). One consequence of this differentiation is that a polarisation is observed between policies aimed at higher management and those aimed at lower levels of personnel. Policies aimed at lower-level employees are mostly initiated by local or national HR departments, whereas policies for higher management are the responsibility of global corporate HR departments. For the latter, transnational recruitment, reward and mobility policies are constructed in order to attract the most talented employees, offering them the opportunity of having an international career, an opportunity given to only a small proportion of the entire work force. In contrast, other parts 
of the corporate labour policy are indeed more dependent upon national and local arrangements (fourth expectation). Transnational firms experience varying degrees of transnationalisation in different parts of their labour policy. The structure of HR departments is the most transnational in character, followed in descending order by rewards, mobility and employee participation.

Finally, by referring to the dynamics of the transnational fields in which these companies have increasingly become embedded, they have indeed attempted to shift certain risks and responsibilities to their employees (fifth expectation). Employees themselves have become more responsible for their own careers. There seems to be little left of a 'psychological contract' (Argyris 1960) governing their career development. Transnational firms also aspire to reduce their responsibility for employee pensions. However, given the embeddedness of the entire reward system in the national field, this change in pension systems has so far proved much more difficult to achieve than the transfer of career risk.

Our analysis of corporate labour policies with two transnational firms has demonstrated that the hypothesis that globalisation fuels a race to the bottom is too simple. The idea of dual embeddedness makes clear that corporate labour policies have to meet expectations in both fields, which has implied a process of differentiation and polarisation of labour relations. Parts of the production process are outsourced to low-cost countries, which especially with Philips, has led to an important reduction in personnel. Labour policies for the remaining lower-level personnel, however, are still highly determined by national regulation. For higherlevel personnel, labour policies are dependent upon developments in the transnational field. This results in a reduction of corporate responsibility for the management of social risks. On the national as well as the international level, labour policies are shaped by the conception of shareholder value, resulting in a shift of responsibility from the company to individual employees. However, on the national level, this development is constrained by national regulation.

\section{Note}

1 This number decreased slightly after 2004 due to the outsourcing of some projects. 


\section{References}

Argyris, Chris 1960. Understanding Organisational Behaviour. Homewood, Il: Dorsey Press.

Atkinson, Anthony B. and Thomas Piketty eds. 2010. Top Incomes. A Global Perspective. Oxford: Oxford University Press.

Baker, George P. and George D. Smith 1998. The New Financial Capitalists. Kohlberg Kravis Roberts and the Creation of Corporate Value. Cambridge: Cambridge University Press.

Baumol, William, Alan Blinder and Edward Wolff 2003. Downsizing in America: Reality, Causes, and Consequences. New York: Russell Sage.

Bjorkman, Ingmar and Günther Stahl 20o6. "International Human Resource Management Research: an Introduction to the Field," pp.1-11 in Bjorkman, Ingmar and Günther Stahl eds. Handbook of Research in International Human Resource Management. Edgar Elgar, 2006.

Bourdieu, Pierre 2005. The Social Structures of the Economy. Cambridge: Polity Press.

Brenner, Robert 1998. "The Economics of Global Turbulence: A Special Report on the World Economy, 1950-98." New Left Review 229: 1-265.

Castles, Francis G. 2004. The Future of the Welfare State. Oxford: Oxford University Press.

Convert, Bernard and Johan Heilbron 2007. "Where Did the New Economic Sociology Come From?” Theory and Society 36 (1): 31-54.

Davis, Gerald and Tracy Thompson 1994. "A Social Movement Perspective on Corporate Control." Administrative Science Quarterly 39: 14173.

Devanna, Mary Anne, Charles Fombrun and Noel Tichy 1999. "A framework for strategic human resource management." Pp. 52-69 in Michael Poole ed. Human Resource Management. Critical Perspectives on Business and Management. London: Routledge.

Fligstein, Neil 1990. The Transformation of Corporate Control. Cambridge, Mass.: Harvard University Press.

Fligstein, Neil 2001. The Architecture of Markets. An Economic Sociology of Twenty-First-Century Capitalist Societies. Princeton: Princeton University Press.

Fligstein, Neil and Taekjin Shinn 2007. "Shareholder Value and the Transformation of the U.S. Economy, 1984-200o." Sociological Forum 4: 399-424.

Fourcade, Marion, and Rakesh Khurana forthcoming. "From Social Control to Financial Economics: The Linked Ecologies of Economics and 
Business in Twentieth Century America." In Charles Camic, Neil Gross, and Michèle Lamont eds. Social Knowledge Making. Chicago: Chicago University Press.

Ghilarducci, Theresa 2008. When I'm Sixty-four: The Plot Against Pensions and the Plan to Save Them. Princeton: Princeton University Press.

Granovetter, Mark 1985. "Economic Action and Social Structure: The Problem of Embeddedness." The American Journal of Sociology 91 (3): 481-510.

Hacker, Jacob 2006. The Great Risk Shift. The New Economic Insecurity and What Can be Done About it. Oxford: Oxford University Press.

Heilbron, Johan 2005. "Taking Stock. Toward a Historical Sociology of Financial Regimes". Economic Sociology 7 (1): 3-17.

Heilbron, Johan, Jochem Verheul and Sander Quak 2011. "Aandeelhouders eerst! De opkomst en verspreiding van aandeelhouderswaarde in de Verenigde Staten." Sociologie 7(1): 21-42.

Jacoby, Sanford 2005. The Embedded Corporation. Corporate Governance and Employment Relations in Japan and the United States. Princeton/ Oxford: Princeton University Press.

Kaufman, Bruce 200o. "Personnel/Human Resource Management: Its Roots in Applied Economics." History of Political Economy 32 Supplement: 227-56.

Kaufman, Bruce 2007. "The Development of HRM in Historical and International Perspective." Pp. 19-47 in Peter Boxall, John Purcell and Patrick Wright eds. The Oxford Handbook of Human Resource Management. Oxford: Oxford University Press.

Mishra, Ramesh 1999. Globalization and the Welfare State. Cheltenham: Edward Elgar.

O'Sullivan, Mary 20oo. Contests for Corporate Control: Corporate Governance and Economic Performance in the United States and Germany. Oxford: Oxford University Press.

Quadagno, Jill 1999. "Creating a Capital Investment State: The New American Exceptionalism." American Sociological Review 64: 1-11.

Quak, Sander forthcoming. Transnational Corporations and National Labour [working title], PhD dissertation, Erasmus University Rotterdam. Sluyterman, Keetie 2005. Dutch Enterprises in the Twentieth Century: Business Strategies in a Small Open Economy. London: Routledge.

Soss, Joe, Jacob Hacker and Suzanne Mettler eds. 2007. Remaking America. Democracy and Public Policy in an Age of Inequality. New York: Russell Sage Foundation. 
Useem, Michael 1993. Executive Defense. Shareholder Power and Corporate Organization. Cambridge, Mass: Harvard University Press.

Useem, Michael 1996. Investor Capitalism. How Money Managers are Changing the Face of Corporate America. New York: Basic Books.

Van Zanden, Jan Luiten 1997. Een Klein Land in de Twintigste Eeuw. Utrecht: Het Spectrum.

Whitley, Richard 1986. “The Transformation of Business Finance into Financial Economics: The Roles of Academic Expansion and Changes in U.S. Capital Markets." Accounting, Organizations and Society 11 (2): 171-92.

Wilterdink, Nico 1995. "Increasing Income Inequality and Wealth Concentration in the Prosperous Societies of the West." Studies in Comparative International Development 30 (3): 3-23. 



\title{
8 From Welfare to Workfare
}

\author{
The Implementation of Workfare Policies
}

\author{
Peter Mascini, Menno Soentken and Romke van der Veen
}

In this book we investigate the transformation of solidarity in modern welfare states. We have learned that welfare state solidarity is still high, but also that it is changing towards more obligatory reciprocity and that it is becoming increasingly dependent upon the deservingness of recipients. In this respect, developments in public opinion are in line with developments in public policies. However, the extent of risk protection is not only dependent upon the policies of the welfare state, it is also dependent upon the risk management strategies of workers, unions, employers' associations and companies, which we have investigated in the preceding chapters. We have learned that the risk management strategies of these actors interact with the way social risks are protected in welfare state arrangements and with the institutions of the (welfare) state. Combined with welfare state arrangements, these strategies constitute the social risk protection provided to citizens.

However, protection against social risks is also dependent upon the way in which social policies are implemented. There are two reasons for this. First, there is always a discrepancy between the formal (legal) reality of arrangements and the daily practice of administration. Dahrendorf (1988) coined this as the distinction between entitlements and provisions. Entitlements alone do not tell us how well citizens are protected against social risks. The entitlements of citizens must be delivered as well. This can be done in a restrictive manner, but also in a more generous manner. Social protection is thus the result of formal entitlements and of the way in which these entitlements are provided for. Second, and more importantly, we have to look at implementation because welfare state arrangements have become increasingly focused on investment and activation in the last ten to fifteen years. This implies that the implementation of arrangements is increasingly directed at preventing people from becoming dependent 
upon social security and on bringing people back into the labour market. However, this also implies that the outcome of welfare state arrangements, in terms of the protection they offer citizens, is becoming increasingly dependent upon the activities deployed by administrative organisations in implementing activating social policies.

Therefore, this chapter deals with the implementation of these activating social policies. What we learn in this chapter is that the provision of social services is indeed of more importance in a 'workfare' state. It often results in the unequal treatment of clients. Social investment will be concentrated on the most promising clients, and the disciplinary working of workfare policies - the conditionality of rights and associated obligations - will be concentrated on the least promising clients.

\section{Introduction: from welfare to workfare}

In the last few decades unemployment policy has shifted from income protection (through social security) to activation (through labour market policy) in most European countries. This shift from income protection towards activation and participation is part of a broader transition from a welfare state towards a workfare state. In contrast to a welfare state, a workfare state is oriented towards recommodifying rather than decommodifying social policies. Decommodifying social policies reduce people's dependency on the labour market. Social insurance and social provisions provided as a social right have this effect: they make people less dependent on their market value and are therefore decommodifying. Recommodifying social policies, on the other hand, strengthen the bond between social policies and the labour market, by helping people in need find a way to return to the labour market. Social policies in a workfare state promote work rather than social protection. They do this by increasing the selectivity and the conditionality of social policies, and by providing services that help people return to employment (Gilbert 2002).

Taylor-Gooby discerns a paradigmatic shift in the transition from welfare to workfare, a new ideology of the welfare state which he describes as 'new welfarism'. This new ideology is the product of socio-economic developments towards a post-Fordist economy. The ideology of new welfarism,

suggests that economic globalization, labour market flexibility, more complex patterns of family life and the dissolution of traditional class 
structures require a new welfare settlement. Since full employment, redistribution and expensive services are no longer seen as feasible, the new welfarism can only justify social spending as investment in human capital and the enhancement of individual opportunities (TaylorGooby 1997: 171).

According to Taylor-Gooby, this new ideology affects all welfare states, because they are all driven in the same direction due to imperatives of international competition.

Jessop (1993) provides a useful summary of the essential changes in social policies that are associated with a turn towards new welfarism. Whereas welfare policies in a traditional welfare system are redistributive, workfare policies are oriented at integration and productivity. Welfare policies are based upon a safety net metaphor, whereas active provision in workfare policies is based upon a trampoline metaphor. Welfare as a safety net results in unconditional rights and few obligations in welfare policies as opposed to workfare and a trampoline effect, where conditional rights are linked to obligations. Workfare policies are, finally, expected to contribute to a future reduction of expenditures whereas welfare policies are expected to cause an increase in expenditures.

In this chapter we will investigate the everyday reality of workfare policies. ${ }^{1}$ Workfare policies intend to contribute to the general willingness to share risks by emphasising individual responsibility and the obligations of welfare recipients as well as by providing services to welfare recipients in order to activate and reintegrate them into the labour market. Our goal in this chapter is to establish how these basic principles of workfare policies have been put into practice and whether workfare policies are an effective investment in human capital and individual opportunities. We do this by adopting a policy implementation perspective. Attention to the mechanisms of policy implementation is important because gaps between formal policies and their execution in practice are quite common (Pressman and Wildavsky 1984). This is particularly true in the case of welfare reform because of its complex and controversial nature (Lurie 2006). According to Lipksy (1980), policy is made during the process of implementation by officials who are in direct contact with welfare clients. This implies that in order to understand the effectiveness of policies it is necessary to pay attention to their implementation. As we will see, the implementation of social policies is known to follow specific mechanisms that can and often do produce unintended and unwanted effects. The first question we address in this chapter is how are the basic principles of workfare 
policy implemented in practice? More specifically, we want to determine if the unintended implementation mechanisms associated with the welfare state have continued to play a role since the workfare state took over, or if they have been replaced by other mechanisms.

Workfare policies were introduced in the Netherlands during the 1990s. After the introduction of the Work and Social Benefit Act (Wwb) in 2004, welfare agencies were obliged to outsource the implementation of workfare policies to private companies. Since 2006, however, this obligation to outsource their total share of workfare services has been abolished. Since then welfare agencies in the Netherlands can choose between outsourcing their services and providing them in-house. This policy change was made because of perceived problems connected to the mandatory outsourcing of workfare policies. This leads to a second research question, which pertains to the implementation of workfare policies in the Netherlands by public and private agencies. The second question of this chapter then is what effect did the abolishment of the mandatory outsourcing of workfare policies to private companies have on the unintended implementation mechanisms connected to the welfare and workfare state?

In the next section we start with a general description of the implementation mechanisms associated with both the welfare state and the workfare state. In the subsequent section we answer the question whether and how these mechanisms have also occurred during the implementation of workfare policies. In the fourth section we analyse the implementation practice of workfare policies following the above mentioned policy change. We base this analysis on a comparative case study of the implementation styles of two public service agencies - a social security agency (Uitvoeringsinstituut Werknemersverzekeringen, UWV) and a municipal social assistance agency - and one private company located in a large Dutch city. We compare the implementation styles of these three offices and study the workings of the unintended implementation mechanisms in public and private agencies. In the concluding section we shed light on the question of why unintended implementation mechanisms are so pervasive and how they affect the implementation of workfare policies. In this final section we will also analyse to what extent workfare policies are effective in emphasising individual responsibility and the obligations of welfare recipients and in activating and reintegrating them into the labour market. 


\section{The implementation of social policy}

\section{1 \\ Social policy implementation in the welfare state}

From WWII until the 1980 s, public policy was predominantly implemented by centralised public administrations in the Netherlands. These centralised bureaucracies were deemed a solution to the vicissitudes and amateurism attributed to private, local social assistance offices that had played an important role in the implementation of social services during the previous period (Terpstra and Havinga 2001). These centralised public administrations particularly strived for strict adherence to the law: enabling citizens to claim welfare services when they were entitled to receive them and excluding all others. The bureaucratic ideal of equal treatment and strict adherence to the law implies that discretion was deemed problematic: officials were not supposed to interpret bureaucratic rules according to their personal views.

However, street-level bureaucrats working in welfare administrations did, in fact, have ample discretion (Lipsky 1980). They used this discretion to cope with unfavourable working conditions, a coping strategy which resulted in a selection of clients. The selection of clients by street-level bureaucrats was not necessarily in compliance with the administrative rules, but was based on informal notions of effectiveness and deservingness. This mechanism of selection is also known as 'creaming', which implies a selection of 'the best' clients. Who 'the best' clients are, is dependent on contextually defined notions of deservingness and effectiveness (Blau 1960).

Moreover, street-level bureaucrats were also known to focus on measurable outcomes (Hasenfeld 1983). Work which produces measurable outcomes tends to drive out work which produces immeasurable output (Wilson 1989: 161). Hence, when the number and accuracy of claims processed in a welfare office are readily observable, a less easily observed output - e.g. being helpful to clients - will be neglected. The tendency to focus on measurable outcomes results in a selective distribution of time and attention by street-level workers with regard to the different activities they are meant to undertake. Not only does it lead to a selection of clients, it also affects what workers do and do not do.

Selection and focus on measurable outcomes are the two most important unintended implementation mechanisms connected to the (regulatory) welfare state. They threaten its basic principles because they result in the unequal treatment of clients and in departures from the law. 


\subsection{Social policy implementation in the workfare state}

Ideas on implementation shifted in many Western countries during the 1980 os. Ideals associated with the welfare state such as equal treatment and strict adherence to the law were increasingly seen as inefficient, limiting freedom of choice and causing administrative organisations to become unresponsive (LeGrand and Bartlett 1993). Discretion in the practice of policy implementation was no longer deemed problematic. Rather, it was now perceived as a necessary condition for improved results: efficiency, responsiveness and entrepreneurship (Brodkin 2006: 6, 8). Furthermore, client selection was considered desirable because it would encourage the efficient spending of scarce public resources. Additionally, the outsourcing of policy implementation to private agencies was deemed to solve the perceived inefficiency and inflexibility of public welfare agencies.

However, the outsourcing of the implementation of public policy has been accompanied by a new unintended implementation mechanism related to the public control of private implementation agencies. It results from asymmetric information when a principal (in this case a public agency) hires an agent (in this case a private company). Information asymmetry renders it difficult for the principal to control the agent and gives the agent the possibility to let his or her own interests prevail. Information asymmetry is a fundamental problem because market parties are profitseeking, which can lead to divergence from the public interest that principals are expected to serve. Principals respond to this problem by drafting detailed contracts in an attempt to prevent market parties from following their own course (Sol and Westerveld 2005: 392). However, contracts cannot guarantee continued compliance, which means that public principals have to monitor the 'good behaviour' of private agents as well. These control measures stimulate bureaucratisation. According to Farrell and Morris (2003), bureaucracy therefore has not disappeared with the transformation from the welfare state to the workfare state, rather, it has shifted. The authors term the bureaucratisation resulting from an outsourcing of public services to private companies a shift to a 'neo-bureaucratic state'.

In short: selection practices and the focus on measurable outcomes are perceived to be particularly problematic in the welfare state because these implementation mechanisms threaten its ideals of equal treatment and strict adherence to the law, whereas bureaucratisation is perceived to be particularly problematic in the workfare state because it threatens its focus on efficiency, freedom of choice, and responsiveness. Hence, both 
the welfare state and the workfare state wrestle with specific unintended implementation mechanisms because each kind of state aspires to different ideals. Our goal in this chapter is to investigate to what extent these mechanisms determine the implementation of workfare policies - workfare being the new and dominant policy to manage social risks - and how these mechanisms affect the results of workfare policies.

\section{The implementation of workfare policies}

In this section we will investigate whether and how the three general implementation mechanisms - selection, a focus on measurable outcomes and bureaucratisation - have manifested themselves in the implementation of workfare policies. This investigation is based on a secondary analysis of previous research on the implementation of workfare policies in Europe and the United States.

\subsection{Selection}

Many studies mention selection in the implementation of workfare policy. Based on an extensive review of previous research on workfare policies, Handler (2008) concludes that recipients with the most barriers to the labour market are offered the fewest services. He states that 'Programs will concentrate on those with the most skills, who are the most employable, who take the least amount of caseworker time and energy to meet statistical goals and who will look like the programs are succeeding' (Handler 2008: 3). Next to formal program characteristics that lead to selection '... caseworkers (will) use informal strategies to encourage enrolment among recipients who (are) most likely to meet agency goals, while discouraging enrolment among applicants with multiple employment barriers' (Handler 2008: 16, for other references, see Grover 2009: 495).

Selection processes in the form of creaming have proven influential in the Netherlands as well. There too, the weakest categories profit the least from active labour market policies (Van Uitert, Van Hoesel and Grijpstra 2007). Hence, it may not come as a surprise that the effectiveness of workfare services in the Netherlands is found to be highest among those whose distance to the labour market is smallest (Kok, Hollanders, and Hop 2006). Rosenthal and Peccei (2006: 1647) find evidence of selection in British implementation practices as well. However, they find that British front-line service providers exert themselves the most for 
the least successful clients because reintegrating them offered the largest rewards in terms of measured performance. In short, selection occurs in the implementation of workfare, but which client categories are favoured depends on incentive structures connected to the measurement of performance. ${ }^{2}$

\subsection{Focus on measurable outcomes}

A focus on measurable outcomes is also manifest in the implementation of workfare policies. Studies show that case workers prioritise goals based on perceived accountability (Riccucci et al 2004). The more case workers believe they will be held accountable for the unlawful assignment of social assistance, the less attention they will pay to activating clients and changing their behaviour and vice versa. Case workers prioritise goals as well as actions not only on the basis of perceived accountability but also on the basis of actual performance measurement. For example, when specific quotas are used to measure the success of enrolling clients in work-related activities as well as starting up workfare trajectories, Brodkin observes that: 'Under pressure to meet quotas, street-level workers focused on "making the numbers," which often meant displacing quality for quantity. [...] caseworkers responded to narrowly constructed performance incentives by pushing people into work programs with little attention to what actually happened once they got there' (Brodkin 2006: 7; for the Netherlands see Van Berkel and Van der Aa 2005). Another example pertains to the sanctioning of clients. In the United States, case workers are held accountable for the amount of hours worked by welfare clients, which can help explain why case workers are inclined to sanction clients even if this undermines the 'work first' principle (Lens 2008). For instance, clients who went to a job interview and therefore did not reach their target of hours worked were sanctioned despite the fact that a job interview enhances their chance of getting a job. Brodkin (2003: 159) also states that 'sanction use increased when front-line workers faced increased risk of being penalized by their managers for failing to catch case errors or when sanctions became easier to apply' ${ }^{3}$ In short, case workers tend to focus on performance measures. '[...] Their practices are shaped by agency incentives and mechanisms that make staff accountable to clients and to the public. [...] Caseworkers generally [seek] the path of least resistance, using discretion in ways most consistent with the logic imposed by the organizational pressures and incentives existing at the street level' (Brodkin 2003: 154, 159). 
There is also evidence that a focus on measurable outcomes can be detrimental to the amount of attention paid to immeasurable outputs. For example, German and British non-governmental organisations (NGOs) engaged in the implementation of workfare policy have been confronted with a changing policy regime during the past few years (Aiken and Bode 2009). Their relationships with public principals have become more contractual: NGOs are increasingly required to account for their results and have to compete with each other as well as with market parties. As a result, it has become more difficult for these organisations to combine their workfare tasks with stimulating the well-being of deprived clients and to maintain contacts with their local network: 'Economic pressures prompted the organizations to cream off the more job-ready, as well as to rely ever more on "regular markets", and this crowded out the former broader integrative approach when social entrepreneurship was coupled with limited economic risk. [...] To put it bluntly: public policies want to get "one plus two" but only pay for "one" ' (Aiken and Bode 2009: 221).

Furthermore, the focus on measurable outcomes has even resulted in the subordination of core tasks, such as diagnosing the strength of clients' labour market positions, formulating a reintegration plan, coordinating services to execute the plan and controlling the implementation process of secondary tasks, such as searching for vacancies with local employers because the latter could be measured more easily than the former. Hill (2005) offers evidence of this coping strategy. He has shown, for example, that specialised offices were more successful in generating job opportunities for unemployed single mothers in the United States than integrated offices. This coping strategy may also explain why specialised offices were more successful in generating job opportunities for unemployed single mothers than integrated offices. Case workers were not triggered to focus on more easily measurable secondary tasks in offices that separated core and secondary tasks, as opposed to case workers who worked in offices where both tasks were integrated.

\subsection{Bureaucratisation}

Bureaucratisation emanating from the outsourcing of workfare policy to private companies is also found in a number of studies. A comparative study of the United Kingdom, Denmark and the Netherlands showed that stakeholders involved in the implementation of workfare policy perceived the short-term thinking of private companies as a serious problem (Lindsay and McQuaid 2008). This tension was felt strongest in the Netherlands, 
where outsourcing was obligatory. Social assistance and social security agencies believed that their dominant position as principal impeded the cooperation with private companies and feared that knowledge about the implementation of workfare policy had leaked to private companies. They also thought that the intensified control of private companies, invoked by the perceived problems with outsourcing, had caused bureaucratisation and high transaction costs. These latter findings were corroborated by a Dutch study from Svensson, Trommel, and Lantink (2008). A marketdriven network, in which employers outsourced the reintegration of sick and disabled employees to private companies, turned out to be more bureaucratic than a corporatist network, wherein employers' organisations and trade unions mutually arranged the implementation of workfare policy or a third network consisting of several equal parties. In a country like the Netherlands, bureaucratisation is particularly present because social assistance and social security agencies attempt to prevent private companies from deviating from their contractual obligations. In sum, policy implementation mechanisms of selection, a focus on measurable outcomes, and bureaucratisation all occur in the implementation of workfare policy.

\section{A comparison of the implementation of workfare policies by public and private agencies}

In this section, we focus specifically on the Dutch case, comparing the implementation of workfare policies by public and private agencies. In 2006, the policy with respect to the outsourcing of workfare policy in the Netherlands was changed in one important respect: municipalities are no longer obliged to outsource their total share of workfare services, meaning they are now free to choose between outsourcing implementation to a private agency or providing direct delivery of workfare services themselves. In other words: municipal social benefit services are no longer fully dependent upon private companies in the Netherlands (for a comparable change in the United States see Warner and Hefetz 2008). Since then, municipalities have increasingly chosen to deliver services themselves because they want more control over their clients, they want to deliver more made-to-measure services and because they were dissatisfied with the price and results of private workfare services (Verveen and Van der Aalst 2006). Hence, this policy change can be seen as a reaction to the unintended consequences created by the obligation to outsource services, which had been in place until 2006. 
We have investigated whether this policy change has affected the three implementation mechanisms of selection, a focus on measurable outcomes and bureaucratisation. We did so by comparing the implementation of workfare policies by two public welfare agencies - a social security agency (UWV) and a municipal social service agency - with a private company in a large Dutch city. This comparative case study is based on eighteen in-depth interviews with managers and case workers as well as document analysis and observations in each organisation. The data were collected in 2008 by Menno Soentken (2009). We concentrate on the implementation practices of case workers and managers. The implementation and enforcement of workfare policies is done by so-called job coaches in the social security agency, by case workers in the municipal social assistance agency and by work consultants in the private company. These street-level workers are all involved with the intake of clients, the formulation of workfare plans with them, monitoring the progress of these plans, and the provision of personal assistance to clients. ${ }^{4}$ In other words, we compare the salience of the three implementation mechanisms between the three agencies that execute more or less identical tasks.

\subsection{Selection and a focus on measurable outcomes}

There is a stronger focus on measurable outcomes in both the social security agency and the social assistance agency than in the private company. In the so-called 'grow and learn model for activation practices' maintained by the social security agency, a focus on outcomes is described as one of the most important competencies of the workfare coach. Three core concepts are discussed in the work manual: 'cost-benefit analysis, the quickest, shortest way to work and the cheapest, most adequate process.' Job coaches working in the social security agency are supervised by a mentor who concentrates in particular on the extent to which coaches focus on measurable outcomes. In both the municipal social assistance agency and the social security agency, targets and listings of individual performances are regularly disseminated. Furthermore, case workers are addressed by management when they do not reach their target. Consequently, employees of both agencies focus strongly on measurable outcomes in their work:

"Every week I pay attention to my results. I look at how many placements I make each week. If I don't manage to reach the set target, I make sure that I fix it. You constantly have to adjust what you're doing in order to reach your goals." Workfare coach four 
"Every two weeks we have to show what our targets are or the number of clients we have activated. If those numbers don't match the target, then our manager will inquire about it." Case worker two

Consultants working for the private company are less outcome-oriented. Managers do not focus on the number of job placements and do not quantify the results of individual consultants. Managers and consultants catalogue results in lists, but only to make sure that reports are written on time. These lists do not serve as an instrument to control the number of clients placed back into the labour market by individual front-line workers:

“... the reason why we keep those lists has solely to do with the reports that have to be produced on time. If you serve a client and I don't know who you've served, I'm not able to check if the report went out on time. From those lists, consultants can see who served how many clients, but that has nothing to do with competition. Far from it. For instance, I can be the one who has placed a client in a job, but then this result can be placed by someone else's name. We're not competitive about it."Manager one, workfare company

The social security agency and the social assistance agency not only focus strongly on outcomes, they also select clients. Employees emphasise that they want to use the available means as efficiently as possible. They tend to offer more opportunities to younger clients or clients with a relatively short distance to the labour market because these clients are believed to be the easiest to activate and, hence, will deliver the best results in terms of performance measures:

"The managers want numbers and I certainly take them into account. So I focus on clients who have recently entered social assistance and clients younger than thirty instead of older people. Employers are not always excited about hiring older people, certainly not if they have been receiving social assistance for a long time. When you start with a group of clients and you have to make a choice, it's logical to start with younger people who have better job opportunities. People who have been on social assistance for years stay in my caseload a bit longer than the rest. I will try to reach them by phone, but I won't focus on them." Case worker three 
Employees also spend more time, energy and available means on clients whom they consider to be motivated:

"For me, it's important that somebody is motivated. That's the most important thing. I make a selection on the basis of motivation, because it is not possible to serve 99 clients at the same time. I just pay more attention to motivated people. I engage in conversations and exert myself more when it comes to them." Workfare coach three

These citations illustrate that in both the social security agency and the social assistance agency, creaming of the most promising clients takes place. Creaming also takes place in the private company, but in a different manner. Consultants exclude difficult clients from the outset. They rely on the public agencies only to supply clients who are ready to be activated. If consultants think there are too many barriers preventing a client's return to work, they send the client back to the public principal:

"If I am certain that somebody is unable to work because, for instance, he or she speaks too little Dutch, he or she won't enter my caseload. Impossible. Then I can't do anything. [...] We have someone who checks out the paperwork of all clients entering this company. That has to be done because case workers can make mistakes too. For example, a person who enters the caseload and can hardly speak Dutch is unacceptable. Hence, we send him back - it's the wrong registration, we can't help him. Clients like that first have to be sent to the naturalisation service by the case worker of the municipality or social security agency." Consultant one

This exclusionary practice does not alter the fact that the tendency to cream is less present in the private company than in both public agencies. Within the private company, services meant to be applied to clients are specified contractually:

"We don't have much to do with efficiency. The tendering procedure for workfare services specifies which means we can use for which groups of clients. The municipality is in control: 'You will get this group of people.' The municipality specifies the target for this group and what has to be done. It's up to us to decide whether we want to work with these clients and whether we want to register for the tender. We calculate: 'What will we get paid for them, can we make a profit from them? Then we know: ' $X$ clients are registered and it is such or such a kind of group'. It is not 
always possible to use instruments such as education in a tendering process. So you have to activate them as it is." Manager two, private company

Management within the private company explicitly states that consultants are not required to focus on outcomes. Rather, they consider timely reporting to be the core task of consultants:

"Consultants don't deal with cost considerations. He or she is responsible solely for deadlines. They have to mind the client and nothing else." Manager one, private company

In short: mechanisms of a focus on measurable outcomes and selection are highly salient in both public agencies, while they are subordinate to timely reporting in the private company. Hence, although the private company operates on the private market, its implementation style is less outcome-oriented than both public agencies.

\subsection{Bureaucratisation}

Employees in both public agencies now have more freedom than before in terms of how they execute their work. Prior to 2006 and the abandonment of mandatory outsourcing, case workers primarily had to account for complying with the rules. Nowadays, procedural accountability is subordinate to accountability for results. This shift is illustrated by the recently introduced management philosophy in the municipal social assistance agency:

"There is a new management philosophy. [...] The essence of it is that we steer on the basis of results and not on the basis of process. We evaluate results in the sense that: 'the final results have to be this or that,' but how you get there, left or right, doesn't matter." Manager one, social assistance agency

Management in the social security agency also emphasises the importance of outcomes in service delivery:

"They can do anything they want as long as they keep in mind: 'What's the added value of what I do?' In order to activate clients, they can go to temporary employment agencies or other workfare companies. If they think they can do something in Groningen [a major city in the north of 
the Netherlands], to help ten people, I will say: 'Go!' The only thing I expect is that they are critical of their actions and ask themselves: 'What did I do and what did it lead to?' And if the answer is: 'Actually, nothing' then they have to skip that activity the next time." Manager Work one social security agency

This attitude implies that employees in both public agencies have the discretion to determine when they treat clients, which services they employ and how much time they spend on each client, as long as the choices they make have a positive effect on the outcome:

"How they fulfil the question of 'how to reintegrate clients' is left to their own discretion and then the results will show whether or not they did this appropriately. This is how things work; if you manage your targets, then freedom comes naturally. But if you claim a lot of freedom and don't achieve anything..." Manager Work one social security agency

In contrast, consultants working in the private company have little opportunity to act based on their own discretion. Clients must be treated in order of arrival and which service they employ is determined by the specific stage a client is in. For example, during the third week of the activation process, clients are required to attend competency training whereas someone who is in the second month of this process is required to do an internship. The choice between services is made on the basis of fixed criteria. The same holds true for the amount of time consultants are allowed to spend on a client and the moment upon which a client has to be outplaced.

The emphasis placed by management on rule compliance does not follow primarily from a preoccupation with justice, but has to do predominantly with the manner in which the company generates income. Income is generated by charging a fee for the various stages of workfare trajectories. Each stage - from signing the contract to an eventual job placement - is invoiced to the social security agency or the municipal social assistance agency. Although the company receives a bonus for the final phase of job placement, this bonus is not the main source of income for private companies. Furthermore, management in the private company continually stresses the timely processing of reports because it thinks timely reports are expected from them by their public principals: 
"There are many kinds of reports. It differs per contract what the principal demands from us. You have to draw up an initial report; there are reports on premature endings, reports on endings based on a lack of motivation, and reports on job placements. There are numerous reports to keep your principal up-to-date on the latest developments, the latest events. If you have dismissed a client due to a lack of motivation, then you have to inform your principal and therefore, you have to hand in your reports on time." Manager two, private company

The application of sanctions is a final indication that the implementation style is more bureaucratic in the private company than in both public agencies. Sanctions can only be imposed by employees of the public agencies. However, private companies provide information which is used by public agencies to determine whether or not to apply a sanction. The management in the private company encourages consultants to report 'non-cooperative' clients as quickly as possible. This strict enforcement of the rules concerning the reporting of 'non-cooperative' clients is financially motivated. The time span within which clients must be outplaced is formalised contractually. When clients are not motivated, the risk of missing deadlines increases. If deadlines are not met, the company loses its fee. Hence, the private company uses sanction procedures as an incentive to change the behaviour of unmotivated clients so that they are ready to proceed to the next stage of the activation process:

"We have six months...within those six months we have to prepare the client, and then, if the client is motivated, the process of activation starts. If the client is not motivated, then the sanction procedure starts in order to make sure certain behaviour is changed, which allows us to start direct mediation again." Manager one, private company

However, in both public agencies, the rules sanctioning 'non-cooperative behaviour' and the 'refusal of suitable jobs' are applied flexibly. Employees forego sanctions if they are convinced that sanctions go against their attempts to focus on job placement and motivating clients:

"Legislation is often rather rigid and we, as job coaches, have to deal with the reality that people are in when they lose their job. If I always applied the law as strictly as possible, many clients would not feel as if they were being helped. Therefore, I have to balance enforcing the law and meeting the client's needs. For instance, I know for sure that if I would rigidly 
enforce the rules regarding suitable work, many clients would feel disrespected when they have to apply for jobs beneath the level they are used to." Job coach four

In sum, in both public agencies, bureaucratic control is subordinate to focusing on the outcomes of workfare policies, while in the private company, the focus is primarily on the steering of the activation process and a strict enforcement of rules concerning non-cooperative clients. The bureaucratic implementation style is not chosen freely by the private company but is imposed by its public principals. Public agencies require private companies to account for their actions in detail in order to prevent the company from shirking the public interest, which the principals are meant to serve. This need for accountability means that a bureaucratic implementation style is prevalent in the private company not despite its operating on a private market, but precisely because of it. In other words, the tendency of the public principal to impose detailed accountability practices is reinforced because the private company operates on a market governed by profit-seeking norms rather than public interest. This conclusion contradicts the empirically grounded, common sense idea that managers in public agencies believe they deal with more red tape than managers in private companies (Feeney and Bozeman 2009). ${ }^{5}$ However, it corroborates Brodkin's (2006: 14) assumption that private agencies that lack strong countervailing constituencies or the powers of resistance available to public bureaucrats, risk being transformed from an alternative to government into an arm of government.

\subsection{Interpreting the differences in policy implementation by public and private agencies}

The latter conclusion explains our finding that the private company operates more bureaucratically than both public agencies. But how can we understand why both public organisations are more outcome-oriented and that their implementation style induces more selectivity than the private company? A possible answer to this question can be derived from institutional theory (Meyer and Rowan 1977; Meyer, Scott, and Deal 1983). The starting point of this theory is that organisations are not closed systems. Rather, their survival is dependent upon their conformity to the normative expectations of their social environment. This mechanism is assumed to be of less importance for organisations operating in a technical environment than for organisations operating in an institutional environment. 
The survival of the former mainly depends on efficient production within a market, while survival of the latter mainly depends on congruence between their functioning and the normative expectations imposed on them by the state. The transformation of the welfare state is connected to the expectation that the state mirrors the market; the ideology of the 'welfare state' is replaced by the ideology of an 'entrepreneurial state' (Smit and Van Thiel 2002).

In this respect, it is understandable that both public agencies attempt to place their market-oriented implementation style in the foreground more so than the private company. After all, the public agencies operate, to a larger extent, in an institutional environment characterised by a market ideology. Unlike the private company, the social security agency is not dependent upon the sales of their services on the private market, but is dependent upon the allocation of means by the state. Moreover, although the municipal social assistance agency is financially accountable for its results, it cannot go bankrupt. The frequent use of business-like terminology indicates that both the social security agency and the social assistance agency have implemented business-like principles. For instance, the quality control employee of the social assistance agency emphasises the importance of entrepreneurship:

"As a case worker, you are in fact an entrepreneur. You have your product, which is that you reach your target. How do you handle that? That's the job of a case worker, his entrepreneurship, like running a shop." Quality control employee social assistance agency one

In another interview, a case worker observes that the mentality in the social assistance agency has become more business-like:

"How you approach things has become more business-like. In 20oo, the culture was softer in the sense of: 'Well, I feel pity for that person and hence I won't take harsh measures'. What you see too is that a new type of colleague has entered the organisation. The old generation has either picked up the new culture or has left the organisation. By 2001 and 2002, many workers had left: they've gone to other municipalities or have gone on to social work, to debt recovery. Job selection is increasingly centred on service provision rather than social work. This attracts a different kind of people. Not the social work type but the more business-like, service type, like you find in a bank. It is no longer feasible to focus on impediments and say: 'Oh dear, oh dear, what a pity.' It is now more an attitude of: 'We 
recognise your impediments, but we ignore them and look at what you can do'. That shift, I mean." Case worker two

In the social security agency, employees have to draw up business plans. The manager checks the progress of these plans and discusses it with his subordinates:

\begin{abstract}
"The business plan is what matters. That determines the actions of job coaches and they have to see it as such. That's how you evaluate the actions of the job coaches. They have specified what they are going to do in their business plans. The expected results are also specified in the plan. I look at them and evaluate to what extent targets are met and discuss that with them. If a coach takes action, he continuously has to think: 'What does that mean for my business plan?' or: 'I see an opportunity, do I have to adjust something in my plan?” Manager one, social security agency
\end{abstract}

This business-like terminology contrasts strongly with that of the private company, where people speak of 'procedures', 'timely processing, 'reports', 'enforcement' and 'accountability'. In this organisation, individual listings of results are not passed around and management does not mention 'entrepreneurship, 'holding a business-like attitude,' 'cost-benefit analyses' or 'business plans'.

In short: the reason why we have observed a stronger business-like orientation - with a focus on measurable outcomes and selection - in both public agencies than in the private company may be the larger extent to which public organisations operate in an institutional environment. Hence, these public agencies are under more normative pressure to conform to business-like practices than the private company, which operates in a more technical environment. The private company is under more pressure to adopt a bureaucratic implementation style given the market they operate on.

\title{
5 Conclusion and discussion
}

\subsection{The implementation of workfare policies}

Our first conclusion is that the unintended implementation mechanisms of selection and focusing on measurable outcomes, previously problematised in the welfare state, play an even greater role in the implementation of welfare policy in the workfare state because of the greater emphasis be- 
ing placed on accountability. The focus on accountability induces creaming of the most promising clients and a focus on activities for which streetlevel bureaucrats are held accountable. However, seen from the policy perspective of the workfare state, these implementation mechanisms are not really problematic because they do not hamper its valued efficiency. However, what is problematic in the light of the workfare ideology is that the transition from welfare to workfare does not automatically decrease bureaucracy and hence impedes the flexibility and responsiveness valued in the workfare state as well. On the contrary, principal-agent problems invoked by the outsourcing of workfare policy to private companies have reinforced bureaucratic tendencies. These bureaucratic tendencies are the unintended consequence of the policy of public organisations to prevent opportunistic behaviour by private companies. Partially contracting back in does not seem to terminate this mechanism: the implementation style of the private company in our study is still mainly bureaucratic.

Our second conclusion is that selection and a focus on measurable outcomes are even more salient in both public service organisations than in the private company, while the reverse is true with respect to bureaucratisation. The former may occur because public organisations operate in a more institutional environment, while private companies operate in a more technical environment. Hence, public agencies are under more normative pressure to conform to business-like practices than a private company, while private companies are under more pressure to adopt a bureaucratic implementation style because the principals they depend on for work demand this from them. This leads to the paradox that public organisations operate in a more business-like manner, while private organisations operate more bureaucratically.

\subsection{The effectiveness of workfare policies}

The final question to be answered is how the workings of the mechanisms of selection, a focus on measurable outcomes and bureaucratisation affect the results of workfare policies. In this respect, our first conclusion is that, as is also observed by Handler (2008) and Brodkin (2006), the increased role of the mechanism of selection and a focus on measurable outcomes will lead to a socially selective implementation of the normative ideals of workfare policies. Social investment, or the provision of activation and reintegration services, will be concentrated on the most promising clients. The disciplinary working of workfare policies - the conditionality of rights and associated obligations - will be concentrated on 
the least promising clients (see also: Jewell 2007). Our second conclusion regarding the effectiveness of workfare policies is that the workings of these mechanisms, particularly the mechanism of bureaucratisation, limit the responsiveness of the implementation of workfare policies. Made-tomeasure services, important in the implementation of result-oriented workfare policies, will hardly be developed either because of a neglect of the needs and interests of the most deprived clients or because of a focus on contract compliance.

In sum: the welfare state has supposedly been transformed into what is alternately designated a workfare, enabling or investment state. All these terms suggest the management of social risks boils down to facilitating the unemployed to find jobs themselves and, hence, increase their agency. However, when one takes the implementation of workfare policy into account, the image of a facilitating, enabling or activating state is not as bright and shiny as it sounds. It basically applies to the unemployed who need it the least, while privatisation puts pressure on the promised flexibility and responsiveness of service delivery because efforts directed at profit making need to be curtailed by continuous monitoring.

\section{Notes}

1 We conceive of workfare policies in the same broad sense as Jessop does, including all activation, reintegration and sanctioning measurements intended to get people (back) to work.

2 According to Handler (2008: 14), selection not only takes place with regard to facilitating reintegration, but also with regard to the sanctioning of clients. He posits that the least successful clients are most likely to be punished: 'The lack of access to childcare, reliable transportation, and the need to care for disabled family members increases the risk of being sanctioned'. Lens (2008) contests this line of thinking. She argues that the sanctioning procedure is dominant in the United States and is applied equally to all clients.

3 The focus on measurable results can even lead to fraud (Grover 2009: 495/6). Handler (2008: 16/7) cites a study by DeParle (2004) who examined the "Wisconsin Works" programme. This programme appeared to be a reintegration success story, even on an international level. However, the focus on measurable results 'led to corruption and mismanagement on the part of the state and local officials and willful ignorance or concealment on the part of the state and local officials. Private agencies were evaluated (and paid) on the basis of the number of clients with employability contracts and whether re- 
cipients were assigned to "a full slate" of activities. To meet these goals, frontline workers employed a variety of methods, from creating and mailing employability contracts to clients without consulting them to simply putting the information in the computer. A subsequent state evaluation demonstrated dismal results. Although all clients were supposed to be involved in some sort of work activity, paid or community service, 67 per cent of clients at Maximus, Inc., one of the principal for-profit contractors, did not have a work assignment. At one point, an internal report showed that although Maximus advertised 100 per cent of the caseload in paid work, in fact only eight per cent were employed' (Handler 2008: 17).

4 Case workers are responsible for numerous tasks related to the implementation of workfare policy. Two of these tasks are excluded here in order to enhance the comparability of the case studies: tasks associated with the outsourcing of services and tasks associated with the judicial aspects of benefits. These tasks are therefore excluded from comparison because they only take place within the public organisations, in this case the social security agency and municipal social service agency.

5 However, the study by Feeney and Bozeman lacks the crucial comparison for us between the perceived red tape of street-level bureaucrats working for public, non-profit agencies and private, for-profit agencies, who perform identical tasks.

\section{References}

Aiken, Mike and Bode, Ingo. 2009. "Killing the Golden Goose? Third Sector Organizations and Back-to-Work Programs in Germany and the UK." Social Policy \& Administration 43(3): 209-25.

Blau, Peter M. 1963. The Dynamics of Bureaucracy: A Study of Interpersonal Relations in Two Government Agencies. $2^{\text {nd }}$ Revised Edition. Chicago: The University of Chicago Press.

Brodkin, Evelyn Z. 2007. "Bureaucracy Redux: Management Reformism and the Welfare State". Journal of Public Administration 17(1): 1-17.

Brodkin, Evelyn Z. 2003. "Street-Level Research: Policy at the Front Lines". Pp. 145-64 in Public Policy into Action. Implementation Research and Welfare Reform, edited by M.C. Lennon and T. Corbett. Washington, D.C.: The Urban Institute Press.

Diller, Matthew. 20oo. "The Revolution in Welfare Administration. Rules, Discretion \& Entrepreneurial Government”. New York University Law Review 75(5): 1121-1222. 
Farrell, Catherine and Jonathan Morris. 2003. "The 'Neo-Bureaucratic' State: Professionals, Managers and Professional Managers in Schools, General Practices and Social Work". Organization 10(1): 129-56.

Feeney, Mary K. and Barry Bozeman. 2009. "Stakeholder Red Tape: Comparing Perceptions of Public Managers and Their Private Consultants". Public Administration Review 69(4): 710-26.

Gilbert, Nigel. 2002. Transformation of the Welfare state. Oxford: Oxford University Press.

Grover, Chris. 2009. "Privatising Employment Services in Britain”. Critical Social Policy 29(3): 487-509.

Handler, Joel F. 20o8. "The Rise and Spread of Workfare, Activation, Devolution, and Privatization, and the Changing Status of Citizenship". Public Law \& Legal Theory Research Paper Series, Research Paper (o8-05).

Hasenfeld, Yeheskel. 1983. Human Service Organizations. Englewood Cliffs: Prentice-Hall.

Hill, Carolyn J. 2005. "Casework Job Design and Client Outcomes in Welfare-to-Work Offices". Journal of Public Administration 16(2): 263-88.

Jessop, Bob. 1993. “Towards a Schumpeterian Workfare State? Preliminary Remarks on Post-Fordist Political Economy". Studies in Political Economy (40): 7-40.

Jewell, Christopher J. 2007. Agents of the Welfare State: How Caseworkers Respond to Need in the United States, Germany and Sweden. New York: Palgrave.

Kok, Lucy M., David Hollanders and Jan-Peter Hop. 20o6. Kosten en baten van reïtegratie (Costs and Benefits of Reintegration). Amsterdam: SEO Economisch Onderzoek.

Le Grand, Julian and Will Bartlett. 1993. Quasi-markets and Social Policy. Basingstoke: Macmillan.

Lens, Vicky. 2008. "Welfare and Work Sanctions: Examining Discretion on the Front Lines". Social Service Review June, 197-222.

Lindsay, Colin and Ronald McQuaid. 2008. "Inter-agency Co-operation in Activation: Comparing Experiences in Three Vanguard 'Active' Welfare States". Social Policy E Society 7(3): 353-65.

Lipsky, Michael. 1980. Street-level Bureaucracy: Dilemmas of the Individual in Public Services. New York: Russell Sage Foundation.

Lurie, Irene. 2006. At the Front Lines of the Welfare System: A Perspective on the Decline in Welfare Caseloads. New York: The Rockefeller Institute Press. 
Meyer, John W. and Brian Rowan. 1977. "Institutionalized Organizations: Formal Structure as Myth and Ceremony". American Journal of Sociology 83(2): 340-63.

Meyer, John W., Richard W. Scott and Terrence E. Deal. 1983. "Institutional and Technical Sources of Organizational Structure: Explaining the Structure of Educational Organizations". Pp. 45-67 in Organizational Environments: Ritual and Rationality, edited by J.W. Meyer and W.R. Scott. London: Sage Publications.

Pressman, Jeffrey L. and Aron B. Wildavsky. 1984. Implementation: How Great Expectations in Washington Are Dashed in Oakland. Berkeley: University of California Press, Ltd.

Riccucci, Norma M., Marcia K. Meyers, Irene Lurie and Jun Seop Han. 2004. "The Implementation of Welfare Reform Policy: The Role of Public Managers in Front-Line Practices". Public Administration Review 64(4): 438-48.

Rosenthal, Patrice and Riccardo Peccei. 2006. "The Social Construction of Clients by Service Agents in Reformed Welfare Administration". Human Relations 59(12): 1633-58.

Smit, Natasja and Sandra van Thiel. 2002. "De zakelijke overheid" (The Business-like Government). Bestuurskunde 11(6): 226-34.

Soentken, Menno. 2009. "Bureaucratie, bedrijfsvoering of professionalisme in de spreekkamer: Een kwalitatief vergelijkend onderzoek naar implementatiestijlen binnen het UWV, een gemeentelijke sociale dienst en een re-integratiebedrijf in een grote Nederlandse stad" (Bureaucracy, Management or Professionalism in the Office: A Qualitative Comparative Research into Implementation Styles Inside a Social Security Agency, a Municipal Social Assistance Agency, and a Reintegration Agency in a Big Dutch City). Unpublished Master's Thesis: Rotterdam.

Sol, Els and Mies Westerveld. 2005. Contractualism in Employment Services: A New Form of Welfare State Governance. Den Haag: Kluwer Law International.

Svensson, Jörgen, Willem Trommel and Tineke Lantink. 2008. "Reemployment Services in the Netherlands: A Comparative Study of Bureaucratic, Market, and Network Forms of Organization". Public Administration Review 68(3): 505-15.

Taylor-Gooby, Peter. 1997. "In Defence of Second-best Theory: State, Class and Capital in Social Policy". Journal of Social Policy 26(2): 171-92

Terpstra, Jan. and Tetty Havinga. 2001. "Implementation Between Tradition and Management: Structuration and Styles of Implementation". Law E Policy 23(1): 95-116. 
Van Berkel, Rob and Paul van der Aa. 2005. "The Marketization of Activation Services: A Modern Panacea? Some Lessons from the Dutch Experience". Journal of European Social Policy 15(4): 329-43.

Van Uitert, Kees, Peter van Hoesel and Douwe Grijpstra. 2007. "Arbeidsmarktbeleid: Privatisering van re-integratie onderzocht. Beschouwing over 22 evaluatiestudies die in 2006 zijn uitgevoerd" (Labor Market Policy: Privatization of Reintegration Studied: Analysis of 22 Evaluation Studies Undertaken in 2006) Tijdschrift voor arbeidsvraagstukken 23(2): 94-105.

Verveen, Ellen and Mechelien van der Aalst. 2006. Opdrachtgeverschap Gemeenten (Commissioning Municipalities). Research voor Beleid, Leiden.

Warner, Mildred E. and Amir Hefetz. 20o8. "Managing Markets for Public Service: The Role of Mixed Public-Private Delivery in City Services". Public Administration Review 68(1): 155-66.

Wilson, James Q. 1989. Bureaucracy: What Government Agencies Do and Why they Do It. New York: Basic Books. 



\title{
9 Towards a New Welfare Settlement?
}

\author{
The Transformation of Welfare State Solidarity
}

Romke van der Veen and Mara Yerkes

\section{Introduction}

In the introductory chapter we distinguished three social foundations of the welfare state. In the first place, there has to be an awareness of the social nature of risks. We defined social risks as risks that do not result from individual choice but as risks that are (also) produced by the social system of production. We discussed the risk of occupational disability in an industrial economy as an example of a social risk. In the second place, there has to be a willingness to share these social risks. Because social risks are, to some extent, risks that are produced by the system of production, there has to be a willingness to handle the negative consequences of these risks (poverty, sickness) collectively. In the third place, the welfare state rests on a number of social institutions intended to manage social risks, such as social insurance, labour market regulation, collective labour agreements and so forth. In the debate about changing welfare states, the emphasis is often on political theories of the welfare state and institutional change because processes of retrenchment or the restructuring of welfare states are highly political in nature. In contrast, we speak of the social foundations of the welfare state and concentrate on sociological theories of the welfare state and of social change in this book because we believe that the primary cause of the transformation of the welfare state is to be found in processes of social change.

Our sociological approach to the changing welfare state departs from quite recent sociological theories on social change, which take the concept of risk and risk perception as their starting point. Sociologists such as Luhmann (1991), Beck (1987), Giddens (1994) and many others have developed theories on social change that accentuate the changing nature of risks and/or risk perception. These theories all predict either implicitly 
(Lumann) or explicitly (Beck, Giddens) fundamental changes to the social foundations of the welfare state and thus in the way welfare states deal with these risks; the welfare settlement so to say.

In a review of recent literature on risk theory, Wilkinson (2001) distinguishes between broad, encompassing sociological theories of risk and risk perception that try to conceptualise social processes of changing risks and risk perceptions and the more mundane, psychometric approach that primarily intends to measure the individual conception of risks and the way individuals react to these risks. Concerning sociological theories, Wilkinson (2001: 2) concludes 'that the appeal of (such) theories lies more in their polemical function than in the extent to which they have detailed clearer conceptions of the social reality in which people acquire and create interpretations of (...) risks'. On the other hand, he is of the opinion that psychometric research into risk perception is hampered by a realist perspective on risks, which is blind to the socially constructed character of the 'objective facts' about risk. Psychometric research tends to isolate respondents and 'records snapshots of risk judgements outside the specific social contexts in which people live (...) perceptions of risks are by no means constant, rather they change in different social settings and in relation to new knowledge and experience of life events' (Wilkinson 2001: 9). Wilkinson is not unique in his criticism and it is this criticism that we try to answer in this book. All the studies that have been reported in this book take sociological theory as their starting point and try to extract testable, empirical hypotheses from these theories. We not only try to test these theories in empirical sociological research, we also try to interpret the results of our enquiries in terms of the consequences they have for the sociological theory we started with. Although we have often, like psychometric researchers, questioned our respondents about risks selected by the researchers, we have tried to contextualise our research, thus creating the opportunity to see the socially constructed and contextual character of risk perceptions.

In this concluding chapter we will explore the consequences of our research findings for sociological theory on the welfare state and for the welfare state itself. We start by giving a bird's eye view of the context of our research: the Dutch welfare state. 
After the economic crisis of the 1970 s and the end of the 'golden era' of the welfare state, the Dutch welfare state underwent a long period of reform and policy change. Beginning in the early 1980s, modest, programmatic reform of the Dutch welfare state occurred. Once the economic crisis abated, it became clear that a limitation on welfare state expenditures was insufficient and serious problems remained. Rampant long-term unemployment and the perverse effects of generous welfare programmes such as sickness and disability benefits continued to afflict the Dutch welfare state, causing reforms to continue well into the 199os. These reforms led to a market-driven managed liberalisation of the welfare state (Van der Veen and Trommel 1999). As a consequence, the universal entitlement to social rights remained but the content and the provision of social rights changed.

This new paradigm of managed liberalisation appears, at first, rather paradoxical. On the one hand, it implies a centralisation of control over the administration of welfare state programmes. On the other hand, it implies a decentralisation of responsibility. The centralisation of control resulted in a stricter definition of citizens' rights and responsibilities, in more conditionality and obligatory reciprocity, and in a focus on rule enforcement. The decentralisation of responsibility led to increased responsibility for employers and employees, an increase in administrative responsibilities of municipalities, and to the partial privatisation of welfare state administration, in particular reintegration efforts.

The transformation of the welfare state has been described by Gilbert as a transformation from a welfare state to a social investment state (2002). He distinguishes four trends: privatisation, increased selectivity, activation and an increase in disciplining; each of these trends can be observed in the transformation of the Dutch welfare state. First, a certain degree of privatisation of public services is visible. Although social rights to services often remain intact, these services (for example, reintegration services) are increasingly delivered by private companies. Privatisation within social security also takes place through the decentralisation of risks to employers, for example with Dutch disability arrangements (Yerkes 2011). It should be noted that the privatisation of services is subject to strict conditions. In other words, privatisation is a form of managed liberalisation, to ensure that public interests are met and are not subordinated to the private interests of firms. 
A second effect of the transformation of the welfare state is an increased selectivity of benefits (Gilbert 2002). In the Dutch case, we have witnessed this increased targeting of benefits but social protection still takes place within a universal system of welfare. In other words, a universal system of social rights remains but entitlement has become more conditional and provision has become targeted towards specific, vulnerable groups. Third, Gilbert points to the shift from welfare states providing income protection to welfare states emphasising improved labour market participation. In the Netherlands, most social security arrangements have been reformed in this manner, with a focus on reintegration and activation.

The final trend evident in the Dutch case ${ }^{1}$ is a development towards the strict enforcement of rules and regulations, particularly in the case of social assistance and social insurance recipients. Social protection in the Dutch welfare state has developed along the lines of a disciplinary mechanism - as a result of increased selectivity in benefits and insurance as well as more stringent definitions and enforcement of rights and responsibilities of benefit recipients. This shift is evident, for example, in the application of sanctions, the increased use of financial incentives and the demands placed on citizens. As a result, there is a great emphasis on reciprocity. The sum of these four trends of policy change is a shift from a decommodifying to a recommodifying welfare state. Efforts are not primarily directed at protecting citizens against the risks of a (post-) industrial economy, but at making citizens autonomous, that is: selfsufficient.

In this context, we reflect upon our research findings in this concluding chapter. We start by giving a summary of our research concerning risk perception and solidarity, concentrating on the theoretical implications of our research in section three. Next, we will give a summary of our research on risk management strategies and on the consequences of our research for theories on institutional and welfare state change in section four. Finally, in section five we will end the chapter by discussing the consequences of our observations for the foundations and development of the welfare state. To what extent can we speak of a gradual development towards a 'new welfare settlement'? Because our empirical research has mainly been executed in the Netherlands, our discussion of the new welfare settlement will focus on the Dutch welfare state. 
Sociological theory on welfare state change departs either from processes of globalisation or from processes of individualisation. Globalisation affects the system of production, networks of economic and social interdependencies and the capacities of nation states to control economic and social processes that take place within their boundaries. The capacity of nation states to control these processes is important because the twentieth-century welfare state is organised within the boundaries of nation states and around the political, economic and social institutions of the nation state. Individualisation affects the way actors see their world, because the social institutions and social bonds that limit the 'freedom' to act are losing their defining and binding power. Individualisation may also affect the level and content of social solidarity in a community because the social bonds between individuals are weakening. Our research has not been directed at these processes of globalisation and individualisation itself, but on the hypothesised consequences of these processes.

In Chapter two we started by investigating the idea of social solidarity. Solidarity is the backbone of the welfare state and is based on the extent to which people are willing to share risks. We investigated two claims in this chapter. First, a claim is often made that welfare state support is diminishing, hypothesised as the unavoidable consequence of social processes of individualisation and globalisation. However, we find that in reality, welfare state support is not decreasing. Rather, it is constant or even increasing. Given the fact that welfare state policies are changing, what does this high level of welfare state support mean? Does high support indicate support for the transformations occurring in the welfare state or, as is often assumed, the contrary: that high support indicates popular feeling is not on par with the transformation most European welfare states are going through? To answer this question, we investigated the nature of social solidarity: under which circumstances and with whom are people willing to share social risks? Our conclusion is that traditional notions of deservingness, need and kinship still determine the level of solidarity people express. However, we also find that the extent to which people trust benefit recipients is low. This low level of trust expresses itself in a high and growing support for obligatory reciprocity within the welfare state. People are willing to share risks on the condition that their solidarity is matched (reciprocated) by the obligations of benefit recipients. The support for obligatory reciprocity can be found with voters of both left and right-wing parties. This means that support for norms of reciprocity 
is independent from the opinions people have about distributive justice. As Mead (1992) put it: the 'politics of conduct' are becoming more important at the expense of the 'politics of class'. Our conclusion is thus that the welfare state is still firmly supported in public opinion because the developments in social policies are in line with developments in public opinion. Both are developing in the direction of more conditionality and obligatory reciprocity.

Having reached the conclusion that welfare state support is still high in the Netherlands and that support for the welfare state in transition is based on an increasingly shared normative ideal of obligatory reciprocity as well as on perceptions of deservingness, we investigated the consequences of the social process of individualisation for welfare state support. Individualisation is expected to undermine welfare state support. However, our findings in Chapter two do not confirm this assumption. Chapter three investigated the relationship between individualisation and risk perception and the willingness to share risks. We made a distinction between cultural or normative individualisation, that is, a process of diminishing social control and increasing individual freedom on the one hand, and structural individualisation, the weakening of the social bond and social relations, on the other hand. Cultural individualisation results in a post-materialist culture as defined by Inglehart (1977). Structural individualisation results in Bowling Alone as characterised by Putnam (2000). We discovered, contrary to our expectations, that individualisation does not necessarily undermine welfare state support. Processes of structural individualisation undermine welfare state support, but cultural individualisation does not. People with low levels of social integration are less supportive of the welfare state - irrespective of their economic interests, whereas people who cherish individuality - cultural individualists - support the welfare state. Their support, however, is related to their economic interests: it increases when their own socio-economic position weakens. Because we find a positive relationship between cultural individualisation and welfare state support, we conclude that individualisation not only strengthens the normative ideals of freedom and self-actualisation, it also makes people more aware of their vulnerability. It is this awareness that feeds welfare state support.

In Chapter four we further investigated this relationship between vulnerability and welfare state support. We once again investigated risk perception and the willingness to share risks in relation to processes of individualisation. In Chapter four, however, we focused on the most important process of individualisation in relation to social security: the in- 
crease of labour flexibility. We asked workers with flexible employment contracts and workers with flexible jobs/tasks how they perceived social risks and to what extent they sought protection from these risks. As was to be expected, we found that as people experience job insecurity, this spurs support for unemployment insurance. The opposite is also true: work secure people, that is, people who expect to find employment easily when in need of a job, show less support for unemployment insurance. However, we find no evidence for the hypothesis that flexibilisation weakens the social bond between workers, which consequently undermines their willingness to share risks, as suggested for example by Sennett (1998). So, the changing nature of work shapes workers' perceptions of risks, fostering a growing need for risk reduction through social insurance. This conclusion confirms our hypothesis that individualisation - in this case in the labour market - can strengthen welfare state support and thus the willingness to share risks because (in this case) labour market flexibilisation makes people more aware of their vulnerability.

Our conclusions thus far do not unconditionally confirm or reject sociological theory on risk perception and welfare state solidarity. What we observe is more complex. We hardly observe a decreasing perception of the social nature of risks. What we do see, is a change in the way people think we have to deal with social risks. Trust is low and the unemployed are held more accountable for their situation. So, the hypothesised increasingly manufactured nature of social risks does not appear to cause a rejection of solidarity through the sharing of risks. Rather, it appears to spur an increasing conditionality of support for the welfare state in reaction to a decrease in trust and perceived deservingness. The same conclusion can be drawn concerning the consequences of individualisation. All in all, individualisation appears to spur a willingness to share risks rather than the other way around. While the willingness to share risks is indeed diminishing among some groups, a more important effect of individualisation seems to be the exact opposite. We conclude that the perceived increased vulnerability of actors in an individualised world is the cause of this willingness to share risks. In short, social solidarity does not conflict with individualisation, rather, it facilitates it. The increased insecurity in other spheres of social life, resulting from individualisation, is compensated by creating a collectively organised safety net through social security. To some extent, this confirms Luhmann's thesis that the awareness of risks will increase in a risk society. 


\section{Social risks and risk management: the changing strategies of social protection}

Perceiving risks as social risks and being willing to share social risks is one thing, being able to transform these perceptions and willingness into actual policies is another. This process is dependent, among other things, upon the institutional environment in which these policies have to be developed and is dependent upon the organisations - firms and administrative agencies - in which they are to be implemented.

Institutional theory on policy change in the welfare state concentrates heavily on mechanisms of path dependency that limit the capacity to adjust policies once they are introduced (Pierson 1994). Increasing returns, resulting from established policies and the administration created to implement these policies, combined with politics of blame avoidance and the veto power of established interests, limit the possibilities of programmatic change (Pierson 200o). Policy change is often achieved via the detour of what is called systemic change, in other words changes in funding or in the governance of policy fields that result in programmatic change in the long run (Van der Veen, Trommel and de Vroom 200o). We have not investigated the political process of policy change in our research; instead, we have focused on actual practices of risk sharing and risk management in firms, unions and employers' organisations, corporatist bargaining institutions and in the daily implementation of social policies. In the end, it is in these practices that policy change must become visible. We wanted to determine to what extent changing perceptions of social risks and the willingness to share risks affects the strategies of risk management in these organisations and institutions.

Our first attempt to open up the black box of changing strategies of risk management concerned the introduction and implementation of the notion of employability. The idea behind employability is that in a new, post-industrial service economy, the Fordist employment relationship has withered away. In an industrial economy, social security was the product of job security realised through stable employment relationships combined with employment insurance when one experiences adversity. From the employability perspective and in a service economy, social security should mainly be the product of strategies to remain employable. By investing in individual capacities and skills and by being flexible and mobile, job security is increased. The concept of employability, which originated in the US, was introduced during the 1990 os in the Dutch welfare state and gradually became an important issue in collective labour agreements. As 
is the case with social security initiatives, the strategy of enhancing social security by investing in employability is hindered by collective action problems once it becomes more than an individual investment. Since employability was seen as an instrument in social security and employment policies in the Netherlands, it became a collective action problem in firms as well as in the negotiations between unions and employers' organisations. The problem is: why invest in the employability of workers if one runs the risk of losing one's investment to the competitor? The traditional solution to this problem of 'poaching', binding the employee to the firm, conflicts with the fundamental values of employability: flexibility and mobility.

Having investigated the development of the policy discourse, the introduction of employability in collective labour agreements and the practice of employability policies in firms in Chapter five, we concluded that in reality, actors were able to overcome these collective action problems with the help of institutions existing within the Dutch corporatist welfare state: the tradition of collective bargaining and the workings of collective labour agreements. In collective bargaining, employer investments in employability were exchanged for the acceptance of increased labour market flexibility by unions. Collective labour agreements helped to overcome the collective action problems raised by employability within firms. The facilitation of gradual policy change by corporatist institutions can be explained by the institutional complementarity that exists in the Dutch corporatist welfare state between the norm of job security and the normative ideals of the strategy of enhancing employability.

In sum, we found that 'old' institutions not only hinder policy change due to mechanisms of path dependency and increasing returns, they can also facilitate policy change through their problem-solving capacities, thus making gradual policy change possible. In other words, corporatism can cause a standstill in policy processes when collectively organised actors and the state are unwilling to cooperate, so-called corporatist immobility, but corporatism can also facilitate policy change when bargaining and exchange is possible: responsive corporatism (Visser and Hemerijck 1997; see also Yerkes 2011). We further investigated the workings of corporatist institutions in Chapter six. In this chapter, we analysed the coverage of 'old' and 'new' social risks in collective labour agreements and the interplay between the policies of the state and the policies of the social partners (trade unions and employers' organisations). We once again find that corporatist institutions can facilitate policy change. On the one hand, it is often suggested that the mechanisms of path dependency limit the transformation of welfare state institutions to respond to new social risks 
(see for example, Bonoli 2005). What we find, however, is that there is an interplay between policies executed at the level of the state and policies developed by the social partners in collective bargaining (see also, Trampusch 2006). This interaction can take the form of compensation in collective bargaining, for example when risk coverage is limited by the state, or the form of new provision when the social partners create protection against (new) social risks not covered by the state. We conclude that the centralised, corporatist character of the Dutch welfare state makes this interplay possible. Therefore, whereas the centralised character of Dutch corporatism is often seen as a cause of immobility, in our research, this centralised character of Dutch corporatism makes innovation and responsiveness possible, leading to the protection of new social risks (work-family balance arrangements) in collective labour agreements. Undoubtedly, the social acceptance of these issues makes corporatist institutions responsive rather than immobile (see Visser and Hemerijck 1997).

In Chapter seven we return to the level of the firm. In this chapter, we investigated the development of labour policies within two 'transnational' firms, an industrial firm and a firm in the service sector. We wanted to know how firms handle their labour policies in a globalising, post-industrial economy. In the discussion on the welfare state in a globalising economy, it is suggested that economic globalisation spurs a 'race to the bottom' and that firms become 'footloose' (Mishra 1999, Castles 2004). Firms are forced to make their labour policies increasingly subordinate to profit-making because of the heightened competition inherent through globalisation and thus they will move to the 'lowest point'. In a globalised economy, 'shareholder value' reigns.

For the research presented in this chapter, we took a different starting point. The idea of 'embeddedness' as introduced by Fligstein (2001), combined with the social field approach of Bourdieu (2005) suggests that the rationality of firms is not only directed at maximising profit, but is always dependent on their history and the fields they operate in. Therefore, the economic rationality of the firm is contextual. In the case of the transnational firms studied here, their embeddedness in different social fields implied that their labour policies were not simply caught up in a race to the bottom, rather they were characterised by differentiation, polarisation and individualisation. In the industrial firm, outsourcing of production took place, which might indeed stimulate a race to the bottom, but at the same time we saw that in both firms labour policies were still highly dependent on national regulation, which prevented a race to the bottom. 
Differentiation in labour policies occurred because labour policy in the transnational field primarily consists of the strategic objectives of the firm and pertains to the higher-educated and internationally mobile labour force. In contrast, labour policy situated in the national field is heavily influenced by national labour markets and social security regulation and is primarily aimed at lower-level personnel. However, this national labour policy also appears to be used in an increasingly strategic manner whereby personnel are increasingly perceived and treated in an instrumental fashion. The shift to the shareholder-value conception of the firm has facilitated this shift from personnel policy towards human resource management, which implies a shift of risks from the company level to individual employees. This individualisation of labour policies implies a diminishing corporate responsibility for workers, for example as observed in pension policies. Here we saw that risks were shifted from the employer to the employee. This shift in risk responsibility was made possible due to the limited influence of national labour policies on firm pension schemes. The chapter on the labour policies of transnational firms makes clear that in an environment where institutional limitations are weakening, firms are still embedded in different fields, which limits their freedom of action. Therefore, labour policies tend to differentiate and polarise. In general, labour policies have become instrumental, spurring a development in the direction of the individualisation of labour policies.

In our last chapter we turned to the implementation of social policies by administrative agencies. Risk management and the protection against social risks is not only dependent on the strategies that workers, unions, employers' organisations and firms develop vis-à-vis the arrangements of the welfare state; it is also dependent upon the daily administration of social policies. The daily practice of administration has become more and more important for risk management and risk protection because welfare state arrangements have become increasingly focused on activation. This suggests that the implementation of arrangements is increasingly directed at preventing people from becoming dependent upon social security and bringing people back into the labour market. This development makes the outcomes of welfare state arrangements, in particular the protection they offer citizens, increasingly dependent upon the activities deployed by administrative organisations in implementing activating social policies.

We found that the informal mechanisms of selection and creaming of clients, which are already present in the traditional administration of welfare policies, play an even bigger role in the implementation of activation 
policies. This is not surprising because activation policies are primarily directed at efficiency and successful reintegration. What is problematic, however, is that the focus on measurable performance and accountability, which is part and parcel of activation policies, can stimulate bureaucratisation and impede flexibility and responsiveness in the implementation of activation policies. This is particularly the case when activation policies are outsourced to private companies.

The implementation processes that lead to selection, creaming and bureaucratisation in the daily administration of activation policies, lead to a socially selective implementation of activation policies that can be counterproductive. Activation policies will be directed at the most promising clients, but these policies will become disciplinary policies when directed at the least promising clients, including the use of sanctions, the conditionality of rights and a strict implementation of obligations (cf. Handler 2008). Secondly, the mechanisms of creaming, selection and bureaucratisation will prevent the development of made-to-measure services, which are important in social policies directed at activation and reintegration. This is an important observation because the outcome of welfare state arrangements in terms of the protection they offer citizens is becoming increasingly dependent upon the activities deployed by administrative organisations in implementing activating social policies.

Having summarised our main findings we now turn to a discussion of the consequences of our research for the development of the (Dutch) welfare state. We do this along two lines: first we will give attention to processes of policy change that have taken place in the Netherlands and discuss the institutional logic of these processes. Secondly, we will try to answer the question whether we are moving towards a new welfare settlement, and, if so, what this new settlement is.

\section{$5 \quad$ Towards a new welfare settlement?}

As noted earlier, the dominant view on the transformation of the welfare state is that policy change is limited because of various mechanisms that promote path dependent changes (for an exception to this, see Yerkes 2011). However, as has been observed before, this view of stagnation and path dependency does not apply to the Dutch welfare state. Visser and Hemerijck (1997) have shown how corporatist institutions facilitated change during the 1980 os and early 1990s, transforming the Dutch disease of the 1980 os into the Dutch miracle of the 199os. Following Katzenstein 
(1985), the flexibility of the Dutch welfare state is also due to the fact that the Netherlands has an open economy and is a small state, and is therefore more vulnerable in the global market.

The research we have presented in this book underscores the power of accommodation present in the Dutch welfare state. And once again, it illustrates the role of corporatist institutions in this process of accommodation. Old institutions facilitate new solutions and gradually, new forms of social risk management have emerged. Gradual change occurs as structural barriers to reform decline (Hacker 2005; Streeck and Thelen 2005) and as the feedback effects of policies cease to become self-enforcing (Hacker 2005). However, structural barriers and feedback mechanisms are not only broken down by the accommodating mechanisms of corporatist institutions, they are also high or low, dependent on the social and political acceptance of policy change. We have illustrated in this book that, contrary to what is often suggested, the social acceptance of policy change in the direction of a recommodifying welfare state based on normative principles of obligatory reciprocity is high. The legitimisation of policy change in this direction is further strengthened by processes of individualisation and flexibilisation that, again contrary to what is often thought, make people aware of their vulnerability and spur the need for welfare arrangements that fit an individualised society and a flexible labour market.

Therefore, a new welfare settlement appears to be gradually developing - one based on continued support for sharing social risks, which also extends to new social risks; one based on a notion of social solidarity that emphasises (obligatory) reciprocity and which is stimulated by bargaining and exchange practices and the accompanying culture of the reconciliation of conflicting interests associated with a corporatist welfare state. This new welfare settlement is characterised by a focus on social security issues focused on participation rather than income protection, through the increase of individual responsibility and the development of new policies of reciprocity.

The shift from decommodifying to recommodifying welfare states has been noted by several scholars, termed alternatively a shift to a social investment state, the enabling state or a push towards new welfarism (Esping-Andersen 2000; Gilbert 2002; Taylor-Gooby 1997). In his article on the new welfare settlement in Europe, Taylor-Gooby (2008) concludes that this new welfarism is characterised by a supposed focus on social investment, but that the reality is often deregulation, targeting and restrictions to benefits. He argues that European welfare states are pri- 
marily successful in negative activation - preventing the take-up of benefits through financial incentives. In a similar vein, Hudson and Kühner (2009) contend that the supposed shift to a social investment state is empirically untenable. In an analysis of 23 OECD countries, the authors find that welfare states are not shifting from protective to productive modes of provision, rather that quantitative evidence points in the opposite direction.

The evidence presented in this volume on the Dutch case suggests a different interpretation of the shift towards a new welfare settlement. We disagree with Taylor-Gooby and Hudson and Kühner that investment does not take place and that activation is only negative activation. Although the Dutch welfare state has been retrenched, at the same time a shift towards a new welfare settlement is taking place. This shift is to be found first and foremost in the gradually changing normative foundation of the welfare state, which is by and large supported by the Dutch public and is, secondly, also gradually introduced in its main institutions: social security, employment policy and collective bargaining. Targeting and restrictions to benefits are part of this new welfare settlement and are not to be interpreted too easily as signs of merely negative activation. They are, thirdly, intended to prevent welfare dependency and should be accompanied by, fourth, social investments. In Chapters five and six we have illustrated that Dutch collective bargaining institutions have responded to changes in social risks allowing for an investment in human capital across the life course. Chapters seven and eight have, however, illustrated the vulnerability of the investment strategy. In other words, while we are moving towards a new welfare settlement, we have not reached it yet.

\section{Note}

1 This differs from Gilbert (2002), who argues that the fourth trend is a change in the concept of citizenship. Citizenship is no longer an encompassing concept based on solidarity and cohesion in national communities. Rather, according to Gilbert, citizenship has now become a concept of membership - membership of a specific group, inclusive of community feeling and values attached to citizenship. 


\section{References}

Beck, Ulrich. 1986. Risk Society. Towards a New Modernity. London: Sage. Bonoli, Giuliano. 2005. "The Politics of the New Social Policies: Providing Coverage against New Social Risks in Mature Welfare States.” Policy and Politics 33: 431-449.

Bourdieu, Pierre 2005. The Social Structures of the Economy. Cambridge: Polity Press.

Castles, Francis G. 2004. The Future of the Welfare State. Oxford: Oxford University Press.

Esping-Andersen, G. 200o. "A Welfare State for the 21st Century. Ageing societies, knowledge-based economies and the sustainability of European welfare states." Background report for the Lisbon Summit, EU.

Fligstein, Neil 2001. The Architecture of Markets. An Economic Sociology of Twenty-First-Century Capitalist Societies. Princeton: Princeton University Press.

Giddens, Anthony. 1994. Beyond Left and Right. The future of radical politics. Cambridge: Polity Press.

Gilbert, Neil. 2002. Transformation of the Welfare State. The Silent Surrender of Public Responsibility. Oxford: Oxford University Press.

Hacker, Jacob. 2004. "Privatizing Risk without Privatizing the Welfare State: The Hidden Politics of Social Policy Retrenchment in the United States." American Political Science Review 98(2): 243-26o

Handler, Joel F. 2008. "The Rise and Spread of Workfare, Activation, Devolution, and Privatization, and the Changing Status of Citizenship". Public Law E Legal Theory Research Paper Series, Research Paper (o805).

Hudson, John and Stefan Kühner. 2009. "Towards Productive Welfare? A Comparative Analysis of 23 OECD Countries", in: Journal of European Social Policy, Vol. 19(1), 34-46.

Inglehart, R. 1977. The Silent Revolution. Princeton: Princeton U.P.

Katzenstein, P. 1985. Small States in World Markets. Industrial Policy in Europe. Ithaca: Cornell University Press.

Luhmann, Niklas. 1991. Soziologie des Risikos. Berlin: de Gruyter.

Mead, L.M. 1992. The New Politics of Poverty: the Non-Working Poor in America. New York: Basic Books.

Mishra, Ramesh. 1999. Globalization and the Welfare State. Cheltenham: Edward Elgar.

Pierson, Paul. 1994. Dismantling the Welfare State? New York: Cambridge University Press. 
- 200o. "Increasing Returns, Path Dependence, and the Study of Politics." American Political Science Review 94: 251-267.

Putnam, Robert. 2000. Bowling Alone. New York: Simon and Schuster.

Sennett, Richard. 1998. The Corrosion of Character. The Personal Consequences of Work in the New Capitalism. New York: W.W. Norton and Company.

Streeck, Wolfgang and Kathleen Thelen. 2005. Beyond Continuity. Institutional change in advanced political economies. Oxford: Oxford University Press.

Taylor-Gooby, Peter. 1997. "In Defence of Second-best Theory: State, Class and Capital in Social Policy." Journal of Social Policy 26(2): 171192.

- 2008. "The New Welfare Settlement in Europe." European Societies 10(1): 3-24.

Trampusch, Christine. 2006. "Industrial relations and welfare states: the different dynamics of retrenchment in Germany and the Netherlands." Journal of European Social Policy 16: 121-133.

Van der Veen, Romke, Willem Trommel and Bert de Vroom. 20oo. "Institutional change of welfare states. Empirical reality, theoretical obstacles." In: H. Wagenaar, Government Institutions: effects, changes and normative foundations. Dordrecht/Boston/London: Kluwer Academic Publishers.

Van der Veen, Romke and Willem Trommel. 1999. "Managed Liberalization of the Dutch Welfare State: A Review and Analysis of the Reform of the Dutch Social Security System, 1985-1998." Governance 12(3): 289-310.

Visser, Jelle and Anton Hemerijck. 1997. A Dutch miracle: job growth, welfare reform and corporatism in the Netherlands. Amsterdam: Amsterdam University Press.

Wilkinson, I. 2001. "Social Theories of Risk Perception: At Once Indispensable and Insufficient". Current Sociology, 49(1): 1-22.

Yerkes, Mara. 2011. Transforming the Dutch Welfare State: Social Risks and Corporatist Reform. Bristol: The Policy Press. 


\section{Index of Names}

Aarts, L. 118

Achterberg, P. 33, 37, 41-42, 52-53, 55,64

Aiken, M. 173

Alford, R.R. 41, 55

Amoore, L. 76

Andeweg, R. 54

Anderson, C.J. 71

Anderson, N. 95

Andriesse, F.G. 98

Argyris, C. 160

Arthur, M.B. 94

Ashford, S.J. 78

Atkinson, A.B. 147

Atkinson, W. 42, 50, 54

Auer, P. 72

Avdagic, S. 122

Baccaro, L. 116, 121

Baker, G.P. 144

Baldwin, P. 16, 24

Bamber, G. 121

Barrett, N. 82

Bartlett, W. 170

Baumol, W. 147

Bauman, Z. 41, 54, 75-76

Beck, U. 7, 15, 21-22, 50-53, 56, 6o, 63, 191-192

Beck-Gernsheim, E. 7, 50-52, 63

Becker, J. 32

Berger, S. 121
Beveridge, W.H. 8

Bismarck, O. von 16

Björkman, I. 148

Blau, P.M. 169

Blekesaune, M. 82

Blom, T. 20

Bobko, Ph. 78

Bode, J. 173

Böckerman, P. 73

Bonoli, G. 22, 24, 27, 116, 200

Bora, A. 20

Bosveld, K. 105

Bourdieu, P. 140-141, 200

Boyne, G. 126

Brakenhoff, M. 105-106

Brandl, B. 116, 120

Brenner, R. 143

Brodkin, E.Z. $170,172,181,184$

Brooks, C. 51, 64, 83

Budd, J.W. 118, 122

Bulmahn, G. 105

Burgoon, B. 71

Burstein, P. 75,83

Butts, S. 95

Campbell, A. 41, 55

Cantillon, B. 7

Castells, M. 64, 70

Castles, F.G. 139, 200

Cazes, S. 72

Clark, A. 73,78 
Clark, T.N. 42

Clayton, R. 26

Collard, B. 96

Collins, H. 70

Connelly, C.E. 77

Converse, P. 55

Convert, B. 141

CPB 99, 101

Crouch, C. 96, 108

Cusack, T. 71

Dahrendorf, R. 165

Davis, G. 145

Deal, T.E. 181

De Beer, P. 55, 73

De Botton, A. 70

De Cuyper, N. 71

De Nijs, W. 122

De Jong, J. 72

De Jong, Ph. 118

De Koster, W. 55

Dekker, F. 64

Dekker, R. 72

Dercks, A. 53

De Swaan, A. 15, 32

Devanna, M.A. 146

De Vries, S. 96

De Vroom, B. 198

De Witte, H. 55, 71, 73

Durkheim, E. 75

Dusschooten, C. 105-106

Duyvendak, J.W. 50

Ebbinghaus, B. 116

Elchardus, M. 7, 23-24, 51, 55

Ellig, B.R. 95

Engelen, M. 117

Erikson, L. 53

Esping-Andersen, G. 8, 22, 24-25, $72,133,202$
Evans, P.B. 9

Ezzy, D. 76

Farrell, C. 170

Flanagan, S.C. 50

Fligstein, N. 140-142, 144, 147, 200

Fourcade, M. 147

Forrier, A. 74

Gallagher, D.G. 77

Gallie, D. 77

Gaspersz, J. 93, 98

Gazier, B. 92-93

Ghilarducci, T. 147

Ghoshal, S. 93-94, 96-97

Giddens, A. 15, 19, 22, 25-26, 49, $64,83,116,191-192$

Gilbert, N. 25, 37, 166, 194, 203

Gilbert, B. 37

Gilens, M. 40, 55

Golden, M. 122

Goldthorpe, J.H. 121

Goodin, R. 17

Gorz, A. 70

Granovetter, M. 141

Green, F. 73

Green-Pedersen, Ch. 32

Grijpstra, D. 171

Grover, C. 171

Hacker, J.S. 8, 27, 139, 147, 202

Hall, P. 8

Hallier, J. 95

Handler, J.F. 171, 184

Hartley, J. 78

Hasenfeld, Y. 169

Hassel, A. 116

Havinga, T. 169

Hechter, M. 41-42, 54, 75 
Heery, E. 70, 80

Hefetz, A. 174

Heilbron, J. 141-142, 144-145

Hellgren, J. 78

Hemerijck, A. 199-200, 202

Hempell, T. 76

Herriot, P. 93

Heywood, J. 118

Hill, C.J. 173

Hillage, H. 92

Hirschman, A.O. 32

Hollanders, D. 171

Höpner, M. 108

Hop, J.P. 171

Houtman, D. 41, 50, 53, 55, 64

Houwing, H. 127

Hudson, J. 204

Hyman, R. 74

ILO 72

Ingelhart, R. 14, 18, 41, 49-50, 52$54,56,196$

Iversen, T. 71

Jacoby, S. 146-147

Jacobson, D. 78

Jasper, J.M. 75

Jenkins, G. 126

Jessop, B. 167

Jewell, C.J. 185

Jirjahn, U. 118

Kaase, M. 32

Kahneman, D. 83

Kalleberg, A. 70

Kashefi, M. 74

Katz, H.C. 97, 120

Katzenstein, P. 26, 71, 202

Kaufman, B. 146

Kemshall, H. 16, 22, 70
Khurana, R. 147

Kittel, B. 120

Klandermans, B. 78

Kok, L. 171

Komter, A. 73,75

Korpi, W. 9, 24, 51

Koster, F. 55, 73

Kräkel. M. 105

Kühner, S. 204

Lange, P. 122

Lansbury, R.D. 121

Lantink, T. 174

Lash, S. 9

Laycock, D. 53

Lazarus, R.S. 78

Lee, A.R. 50

Lee, C. 78

LeGrand, J. 170

Leibfried, S. 51

Leisering, L. 51

Lens, V. 172

Leynse, F. 99

Lieon, S. 119

Lindbeck, A. 76

Lindsay, C. 173

Lipset, S.M. 40-41, 55

Lisky. M. 167, 169

Littleton, S.M. 94, 96

Longstreth, F. 8

Luhman,n, N. 15, 20-22, 191, 192

Lurie, I. 167

Mailand, M. 121

Mantza, J. 51, 64, 83

Marshall, G.H. 55

Mau, S. 37

McAllister, I. 41, 54

McQuaid, R. 173 
Mead, L.H. 42

Mes, H. 98

Meyer, J.W. 181

Middendorp, C. 52, 55

Miller, W. 55

Mishra, R. 139, 200

Morris, J. 170

Moss-Kanter, R. 74, 93-98

Mumford, K. 118, 122

Murray, Ch. 32

Näswall $71,73,78$

Nagelkerke, A. 122

Newton, K. 32

Nieuwbeerta, P. 41, 55

Nijhuis, T. 20,

Norris, P. 52

OECD 72

Offe, C. 9

Olson, M. 96

Orr, D.B. 94

O’Sullivan, M. 145

Ott, M. 93, 98

Page, B.I. 83

Pakulski, J. 41, 51, 54

Palier, B. 27,

Peccei, P. 171

Pemberton, C. 93

Pettersen, P.A. 82

Pierson, P. 8, 26, 37-38, 64, 198

Pestiau, P. 7

Piketty, T. 147

Planken, T. 98

Polletta, F. 75

Pools, M. 126

Pontusson, J. 26, 71

Porter, M.E. 97

Postel-Vinay, F. 73, 78
Pressman, J.L. 167

Protsch, P. 77

Putnam, R. 196

Quadagno, J. 82, 147

Quak, S. 148

Rajan, A. 95

Raven, J. 33, 37, 53

Rein, M. 120

Rempel, M. 42

Riccuci, N.M. 172

Ringen, S. 32

Rodrik, D. 71

Rojer, M. 117

Rose, R. 41, 54

Rosenthal, P. 171

Rousseau, D.M. 94

Rowan, B. 181

Rueschmeyer, D. 9

Salmon, J. 70, 80

Savage, M. 41, 54

Savickas, M.L. 94

Schalk, R. 95

Schils, T. 127

Schmid, G. 70, 93

Schreuder, K. 102, 122

Schwartz, R. 26,

Schulze Buschoff, K. 77

Schumpeter, J.A. 93

Schwitters, R. 15

Scott, R.W. 181

Sels, L. 74

Sennett, R. 70, 75-76, 197

SER 99

Shapiro, R.Y. 83

Shin, T. 147

Shivo, T. 82

Siegel, N.A. 116 
Simoni, M. 116, 121

Skocpol, T. 8-9

Sluyterman, K. 149

Smith, G.D. 144

Smith, N. 182

Snower, D. 76

Soentken, M. 175

Sol, E. 170

Soss, J. 147

Stahl, G. 148

Streeck, W. 8, 27, 202

Steinmo, S.H. 8

Stichting van de Arbeid 98-99

Stokes, D. 55

Svensson, J. 174

Svalfors, S. 32, 41, 55

Sverke, M. 78

Tamkin, P. 92

Taylor-Gooby, P. 7, 14, 17, 21-22, $25,32,83,92,166-167,203-204$

Terpstra, J. 169

Thelen, K. 8, 27, 202

Thompson, T. 145

Tijdens, K. 102, 117, 119

Trampusch. C. 116, 118, 125, 200

Traxler, F. 116, 120-121

Trommel, W. 49, 174, 193, 198

Turner, B.S. $38,41,54$

Tversky, A. 83

Urry, J. 9, 19

Useem, M. 144

Uusitalo, H. 82

Van Berkel, R. 172

Van der Aa, P. 172

Van der Aalst, M. 174

Van der Veen, R.J. 27, 33, 37-38,
49, 53, 118, 193, 198

Van Echtelt, P. 74

Van Hoesel, P. 171

Van Klaveren, M. 117

Van Oorschot, W. 33, 41, 50, 55, 71, 73, 75, 78, 81

Van Parijs, P. 7

Van Thiel, S. 182

Van Uitert, K. 171

Van Vuuren, T. 78

Van Zanden, J.L. 143

Veenis, J. 99

Verveen, E. 174

Visser, J. 52, 77, 116-117, 119, 121,

199-200, 202

Vossen, M. 117

Wailes, N. 121

Wallerstein, M. 122

Warner, M.E. 174

Waterman, R.H. 94-96

Waters, M. 41, 51, 54

Welzel, C. 52

Westerveld, M. 170

Wheeler, H.N. 97

Whitley, R. 147

Wildavsky, A.B. 167

Wilkinson, I. 192

Willms, J. 51

Wilson, J.Q. 169

Wilterdink, N. 147

Wright, E.O. 55

Yang, P. 82

Yerkes, M. 119-120, 199

Zinn, J. 21

Zagelmeyer, S. 120

Zwick, T. 76 



\section{Index of Subjects}

Collective Bargaining 118-122, 132-133, 199-200

Collective Labour Agreement

(CLA)

- and employability 101-105, 199

- and risks 116-117, 124, 130, 200

Collectivisation 15-16

Conception(s) of control 141

Corporate labour policy 142, 146147, 156-157, 159, 201

Corporatism 199-200

Deservingness 39, 40, 195

Embeddedness 140-142, 159, 200

Employability

- and collective action problems 96, 105, 199

- defined 92, 100

- and social security 97,108 , 198

Enabling state 25

Flexibilisation 70

- and feelings of security 71 , 73-74, 80

- and risk 70, 73-74

- and welfare state support 71 , 75-76, 81, 83, 197

- flexible contracts 73,77

- functional flexibility 72,78

Free rider problem 15
Globalisation 18

Human Resource Management $140,146,148,153-156$

Implementation 169, 174-183, 201-202

- and private agencies 170, 202

- implementation style 168

- unintended outcome of 171 174, 183-184, 201-202

Increasing returns 26,198

Individualisation 18, 50, 196

- and class 53

- and risk 52

- and welfare state support 55, 59-61, 65, 196-197

- cultural i. 50-51, 56, 59-60, 62

- structural i. 50-51, 56, 59, 61-62

Knowledge economy 23

Manufactured risk

- see risk

Neo-liberalism 33, 121

New welfarism 24-26, 166-167,

194, 202-203

New Risks

- see risk

Post-industrial society 72,198

Post-materialism 14, 52, 56

Reciprocal reform 39,43 
Reciprocity 37

- obligatory reciprocity 43-44, 195

Recommodifying reform 193-194

Redistributive reform 39, 43

Risk 20-22, 24

- and collective bargaining 116, 118-122

- and the welfare state 15,191

- management of risk 14, 24, 132-133, 159-16o, 184-185, 194, 198-202

- manufactured risk 19, 24-25, 197

- new risks $15,18,22-23,116$, 119, 131, 199, 203

- old risks 116, 119, 131

- perception of risk 14, 73-74, 192, 194-197

- risk culture 20

- risk society 21, 197

- risk syndrome 20, 22

- sharing of risk 15, 130-132, 194

- social risk 15
- willingness to share risk 14, 24

Risk Society

- see risk

Share holder value $142-144,146-$ 147,200

Social investment state 25 Solidarity

- see also willingeness to share risks

- and risk perception 195-197

- welfare state solidarity 14

Street-level bureaucracy 169-170 There is no alternative (TINA)

25-26

Transnationalisation $142,148-152$, 159

Welfare state support $32,34,54$,

$57,65,71,75-76,83$

- and class 40-41

- and identity 41-42

- and policy change $38,193-$ 194

- and social scecurity 35-36

Workfare $166-167,170$ 


\section{CHANGING WELFARE STATES}

\section{PREVIOUSLY PUBLISHED}

Jelle Visser and Anton Hemerijck, A Dutch Miracle. Job Growth, Welfare Reform and Corporatism in the Netherlands, 1997 ISBN 9789053562710

Christoffer Green-Pedersen, The Politics of Justification. Party Competition and Welfare-State Retrenchment in Denmark and the Netherlands from 1982 to 1998, 2002 ISBN 9789053565902

Jan Høgelund, In Search of Effective Disability Policy. Comparing the Developments and Outcomes of the Dutch and Danish Disability Policies, 2003 ISBN 9789053566442

Maurizio Ferrera and Elisabetta Gualmini, Rescued by Europe? Social and Labour Market Reforms from Maastricht to Berlusconi, 2004 ISBN 9789053566510

Martin Schludi, The Reform of Bismarckian Pension Systems. A Comparison of Pension Politics in Austria, France, Germany, Italy and Sweden, 2005 ISBN 9789053567401

Uwe Becker and Herman Schwartz (eds.), Employment 'Miracles'. A Critical Comparison of the Dutch, Scandinavian, Swiss, Australian and Irish Cases Versus Germany and the US, 2005 ISBN 9789053567555

Sanneke Kuipers, The Crisis Imperative. Crisis Rhetoric and Welfare State Reform in Belgium and the Netherlands in the Early 1990s, 2006 ISBN 9789053568088

Anke Hassel, Wage Setting, Social Pacts and the Euro. A New Role for the State, 2006 ISBN 9789053569191

Ive Marx, A New Social Question? On Minimum Income Protection in the Postindustrial Era, 2007 ISBN 9789053569252

Monique Kremer, How Welfare States Care. Culture, Gender and Parenting in Europe, 2007 ISBN 9789053569757

Sabina Stiller, Ideational Leadership in German Welfare State Reform. How Politicians and Policy Ideas Transform Resilient Institutions, 2010 ISBN 9789089641861 
Barbara Vis, Politics of Risk-taking. Welfare State Reform in Advanced Democracies, 2010 ISBN 9789089642271

Bruno Palier (ed.), A Long Goodbye to Bismarck? The Politics of Welfare Reform in Continental Europe, 2010 ISBN 9789089642349

J. Timo Weishaupt, From the Manpower Revolution to the Activation Paradigm. Explaining Institutional Continuity and Change in an Integrating Europe, 2011 ISBN 9789089642523

Uwe Becker (ed.), The Changing Political Economies of Small West European Countries, 2011 ISBN 9789089643315 
The Transformation of Solidarity: Changing Risks and the Future of the Welfare State investigates the consequences of processes of social individualisation and economic globalisation for welfare state solidarity. Solidarity is defined as the willingness to share risks. The institutions of the welfare state, such as social security or health care insurance, are founded on the willingness of citizens to share risks and organise solidarity between the young and the old, between the healthy and the sick, between the working and the unemployed. Processes of individualisation and globalisation affect these risks and in this study the authors investigate how and to what extent these changes influence the way risks are perceived by the public, what this means for the willingness to share risks and how this is translated in risk management strategies in firms, unions and administrative agencies.

Romke van der Veen is Professor of Sociology at the Erasmus University Rotterdam. Mara Yerkes is Senior Research Fellow at the Institute for Social Science Research of the University of Queensland, Australia. Peter Achterberg is Associate Professor of Sociology at the Erasmus University Rotterdam.

This book provides new insights, in particular in the influence of different types of individualisation on welfare state solidarity, in the relation between work insecurity and the support for the welfare state, and in the constructive role of 'old' institutions in policy change. Robert Knecht lectures in Sociology of Law and is Director of Research at the Hugo Sinzheimer Institute at the University of Amsterdam.

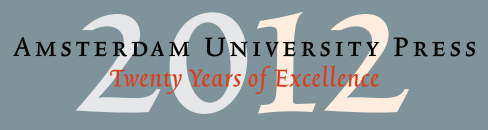

WWW.AUP.NL

ISBN 9789089643834

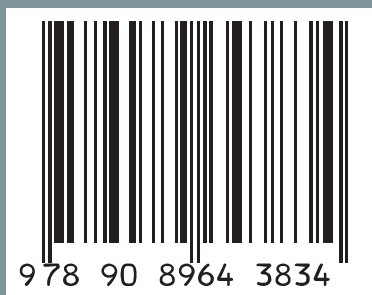

